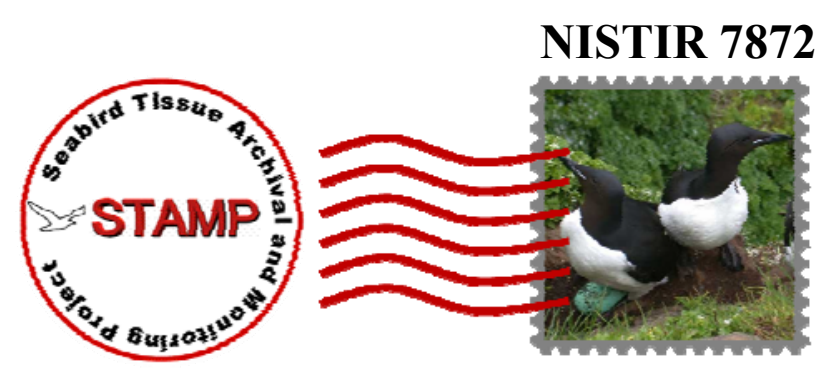

\title{
SEABIRD TISSUE ARCHIVAL AND MONITORING PROJECT: Egg Collections and Analytical Results for 2006-2009
}

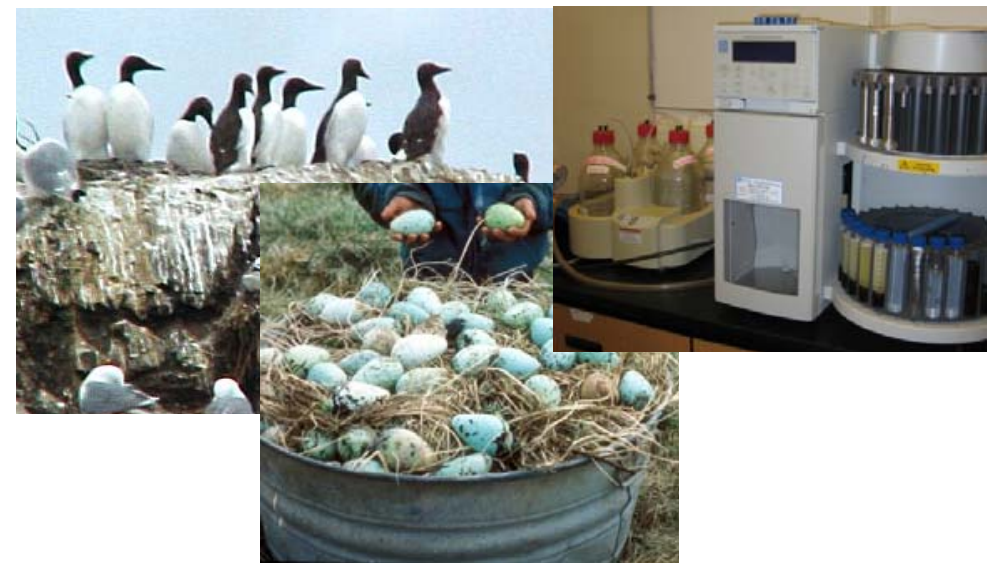

\author{
Stacy S. Vander Pol ${ }^{1}$ \\ Paul R. Becker ${ }^{1}$ \\ Sylvain Berail ${ }^{2}$ \\ Rusty D. Day ${ }^{1}$ \\ Olivier F.X. Donard ${ }^{2}$ \\ Keith A. Hobson ${ }^{3}$ \\ Amanda J. Moors ${ }^{1}$ \\ Rebecca S. Pugh ${ }^{1}$ \\ Lauren B. Rust ${ }^{1}$ \\ David G. Roseneau ${ }^{4}$
}

http://dx.doi.org/10.6028/NIST.IR.7872

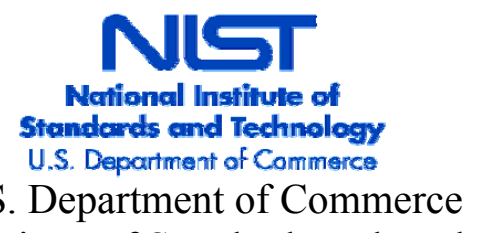

${ }^{1}$ U.S. Department of Commerce

National Institute of Standards and Technology

Material Measurement Laboratory

Analytical Chemistry Division

Hollings Marine Laboratory

Charleston, SC 29412
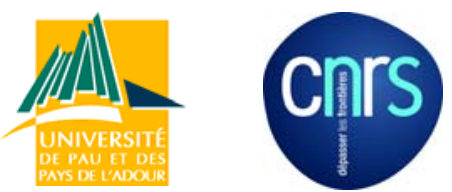

${ }^{2}$ Institut Pluridisciplinaire de Recherche sur l'Environnement et les Materiaux, Equipe de

Chimie Analytique BioInorganique et

Environnement, UMR CNRS 5254

64053 Pau, France

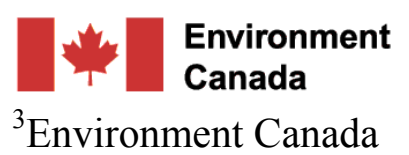

Stable Isotope Hydrology and Ecology

Research Laboratory

11 Innovation Blvd.

Saskatoon, SK 27N 3H5 Canada

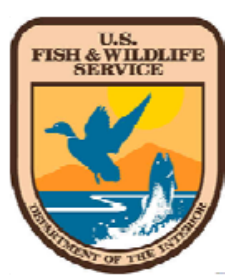

${ }^{4}$ U.S. Department of the Interior U.S. Fish and Wildlife Service Alaska Maritime National Wildlife Refuge Homer, AK 99603 
NISTIR 7872

\title{
SEABIRD TISSUE ARCHIVAL AND MONITORING PROJECT: Egg Collections and Analytical Results for 2006-2009
}

\author{
Stacy S. Vander Pol ${ }^{1}$ \\ Sylvain Berail ${ }^{2}$ \\ Olivier F.X. Donard ${ }^{2}$ \\ Amanda J. Moors ${ }^{1}$ \\ Lauren B. Rust ${ }^{1}$
}

Paul R. Becker ${ }^{1}$

Rusty D. Day ${ }^{1}$

Keith A. Hobson ${ }^{3}$

Rebecca S. Pugh ${ }^{1}$

David G. Roseneau ${ }^{4}$

${ }^{1}$ U.S. Department of Commerce National Institute of Standards and Technology

Material Measurement Laboratory

Analytical Chemistry Division

Hollings Marine Laboratory Charleston, SC 29412

${ }^{2}$ Institut Pluridisciplinaire de Recherche sur l'Environnement et les Materiaux Equipe de Chimie Analytique BioInorganique et Environnement UMR CNRS 5254 $64053 \mathrm{Pau}$, France

${ }^{3}$ Environment Canada Stable Isotope Hydrology and Ecology Research Laboratory 11 Innovation Blvd. Saskatoon, SK 27N 3H5 Canada

${ }^{4}$ U.S. Department of the Interior U.S. Fish and Wildlife Service Alaska Maritime National Wildlife Refuge Homer, AK 99603

http://dx.doi.org/10.6028/NIST.IR.7872

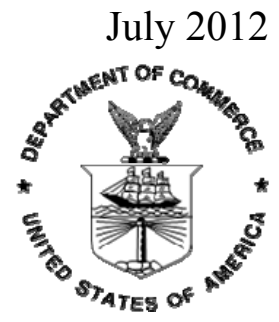

U.S. Department of Commerce Rebecca Blank, Acting Secretary 


\section{Table of Contents}

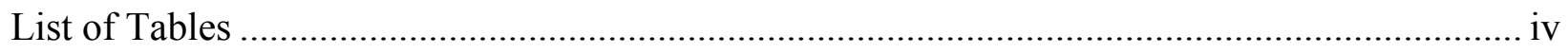

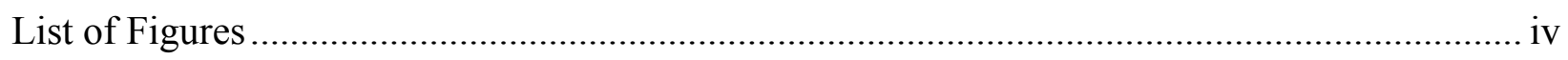

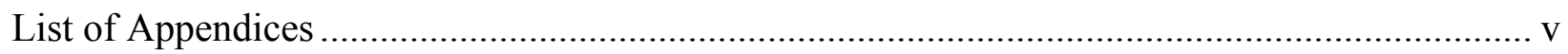

Acknowledgements ........................................................................................................ ix

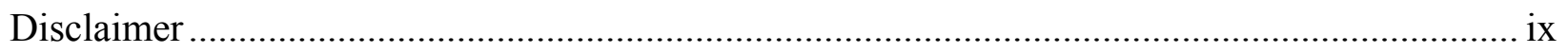

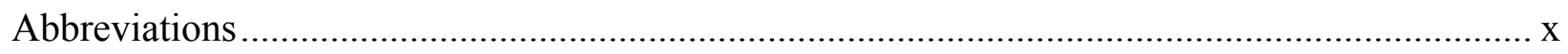

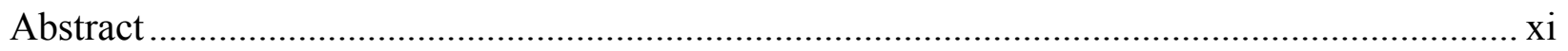

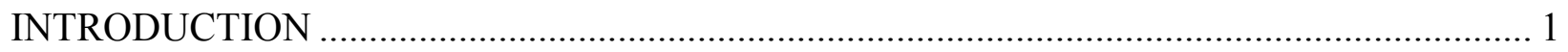

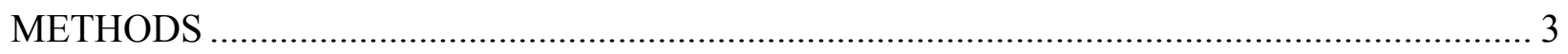

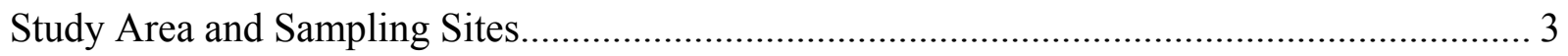

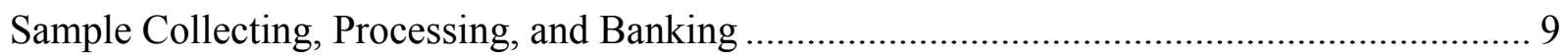

Mercury and Hg, Carbon, and Nitrogen Isotopes ............................................................... 9

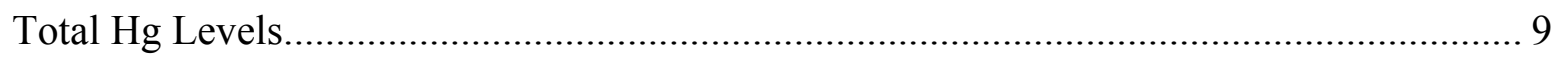

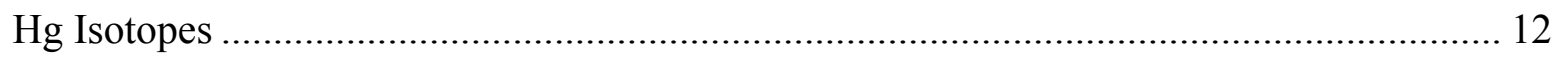

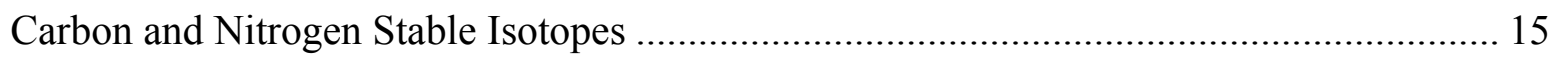

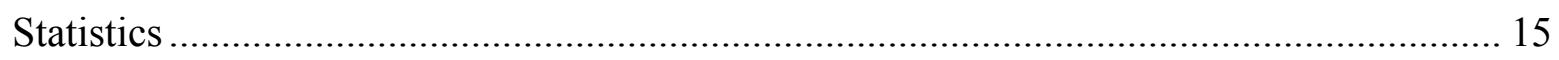

Persistent Organic Pollutants (POPs) …………………..................................................... 15

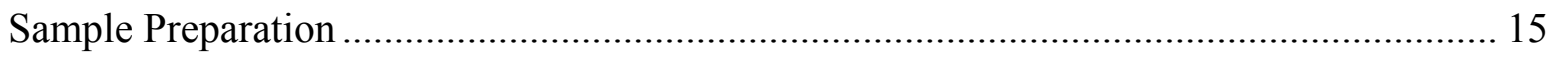

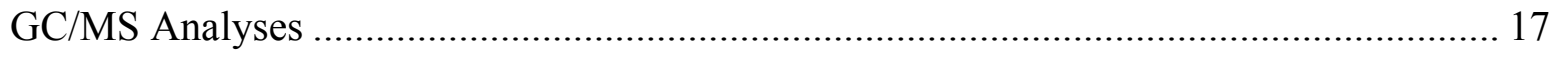

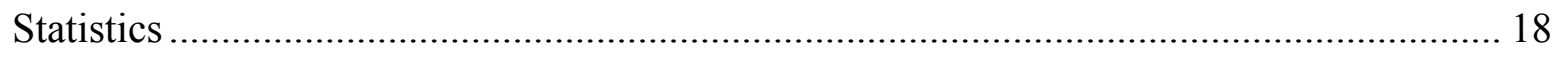

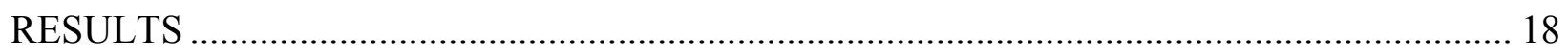

Mercury (Hg) and Hg, Carbon (C), and Nitrogen (N) Isotopes............................................... 18

Taxonomic Groupings .................................................................................................... 18

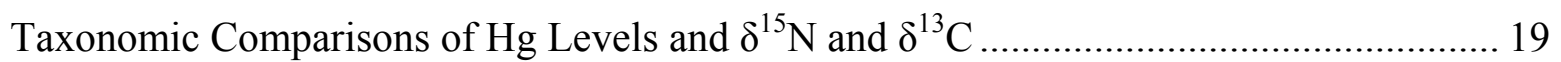




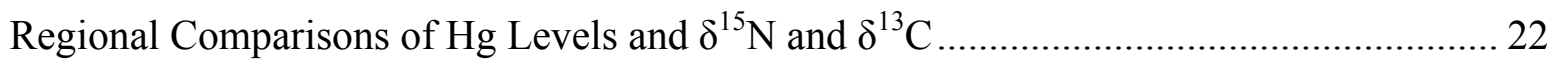

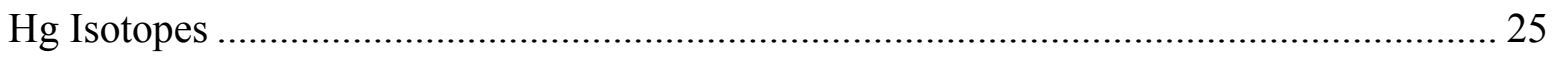

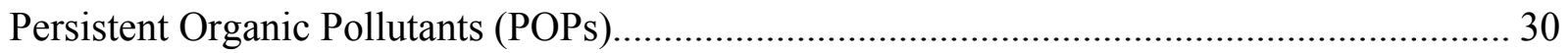

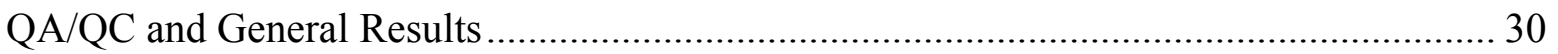

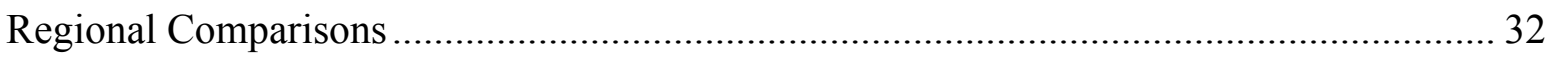

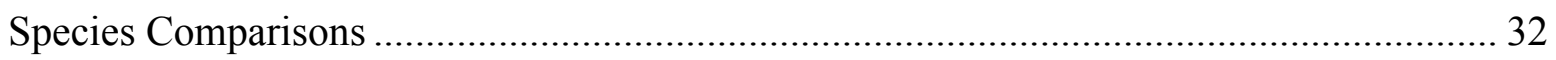

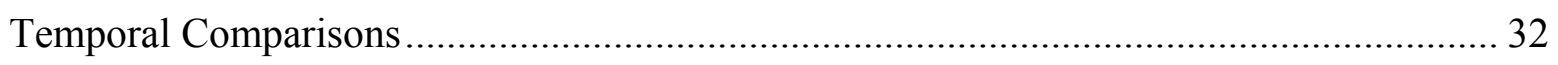

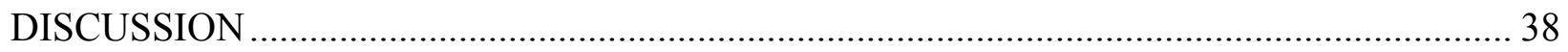

Mercury (Hg) and $\mathrm{Hg}$, Carbon (C), and Nitrogen (N) Isotopes......................................... 38

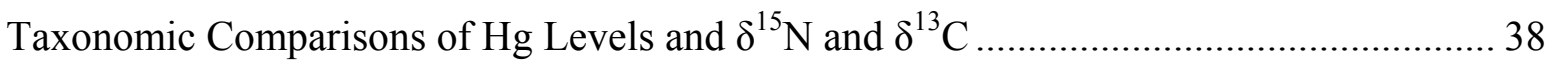

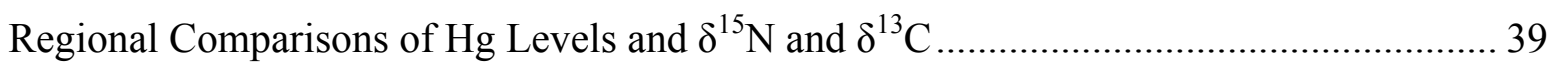

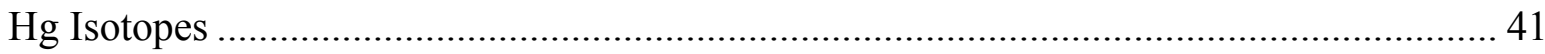

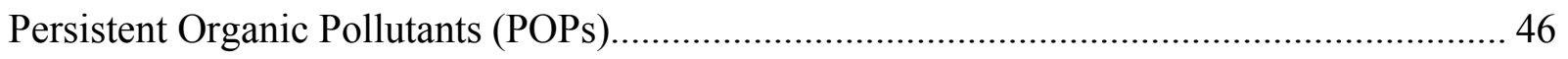

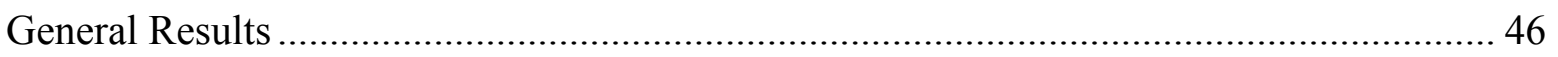

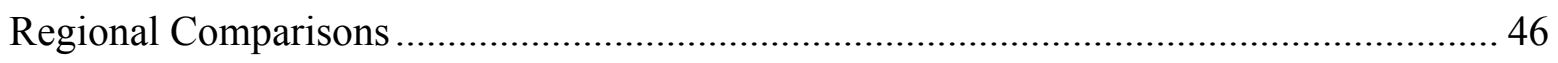

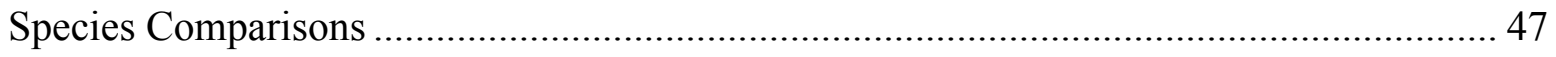

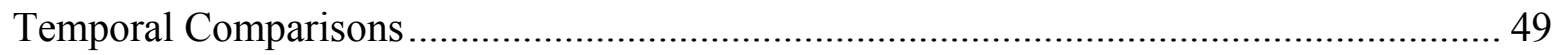

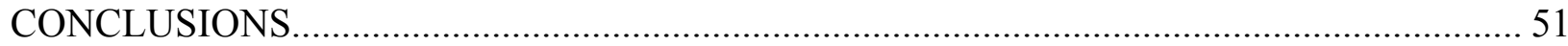

Mercury and $\mathrm{Hg}$, Carbon, and Nitrogen Isotopes ........................................................ 51

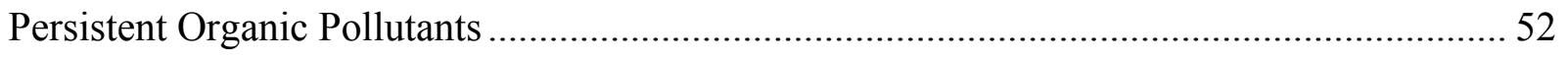

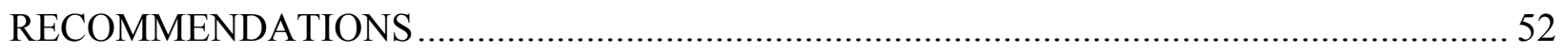

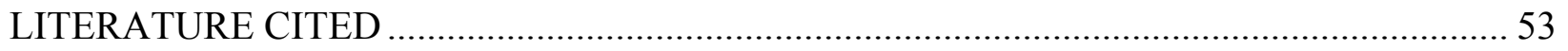




\section{List of Tables}

Table 1. The 2008-2009 Seabird Tissue Archival and Monitoring Project (STAMP) seabird egg

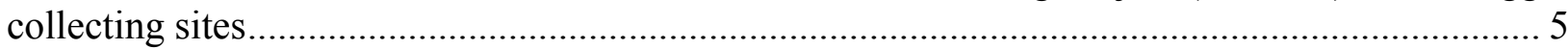

Table 2. Clutches of seabird eggs banked by the Seabird Tissue Archival and Monitoring Project (STAMP) in the Marine Environmental Specimen Bank in Charleston, SC.................................. 6

Table 3. Hg measurements of QC04-ERM1 Egg Reference Material 1 and blanks .................... 11

Table 4. Murre eggs from representative colonies that were analyzed for $\mathrm{Hg}$ isotopes ................ 13

Table 5. Quality control sample mercury isotope values compared to previously reported

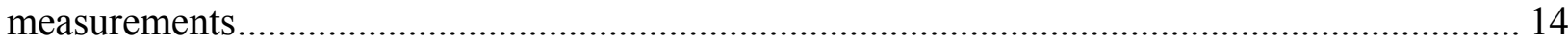

Table 6. Mass fractions of of major contaminants in murre and gull eggs................................... 35

Table 7. Correlations between major contaminants and carbon and nitrogen isotope ratios found in common murre and glaucous gull eggs collected in 2008-2009 48

\section{List of Figures}

Figure 1. The 2006-2009 Seabird Tissue Archival and Monitoring Project (STAMP) seabird egg collecting sites.

Figure 2. General location of the Norton Sound - Bering Strait study area................................... 7

Figure 3. The 13 nesting locations in the Norton Sound - Bering Strait study area where murre and gull eggs were collected in 2008-2009.

Figure 4. Hg levels in common murre and thick-billed murre eggs from St. Lawrence (northern Bering Sea) and St. Lazaria (southern Gulf of Alaska) islands 20

Figure 5. Hg isotope patterns in common murre and thick-billed murre eggs from St. Lawrence (northern Bering Sea) and St. Lazaria (southern Gulf of Alaska) islands .................................... 20

Figure 6. Hg levels in murre and gull eggs among regions ....................................................... 21

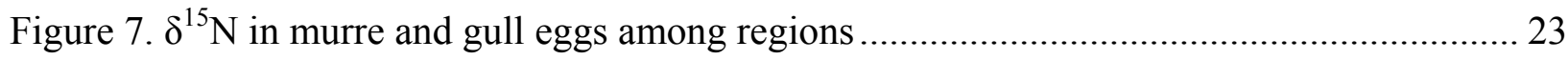

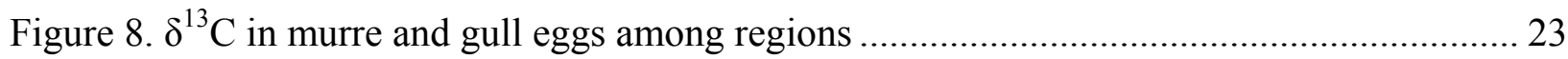

Figure 9. $\mathrm{Hg}, \delta^{15} \mathrm{~N}$, and $\delta^{13} \mathrm{C}$ in gull eggs compared among colonies ........................................ 24

Figure 10. $\delta^{200} \mathrm{Hg}$ and $\delta^{199} \mathrm{Hg}$ vs. $\delta^{202} \mathrm{Hg}$ for all murre and gull eggs showing measured values relative to theoretical values based on mass dependent kinetic isotope fractionation.................. 26 
Figure 11. A three $\mathrm{Hg}$ isotope diagram showing colony separations by their $\Delta^{199} \mathrm{Hg} v s \delta^{202} \mathrm{Hg}$ signatures

Figure 12. Hg, MIF, and MDF gradients between the Norton Sound and northern Bering Sea regions. 28

Figure 13. $\delta^{15} \mathrm{~N}$ and $\delta^{13} \mathrm{C}$ gradients between the Norton Sound and northern Bering Sea regions

Figure 14. Slope of the linear regression between $\Delta^{199} \mathrm{Hg}$ and $\Delta^{201} \mathrm{Hg}$ 30

Figure 15. Percent lipid in common murre, thick-billed murre, glaucous gull and glaucouswinged gull eggs collected at 19 Alaskan colonies in 2008-2009.

Figure 16. Geographic comparisons for common murre eggs collected from Bering Sea and Norton Sound regions, and glaucous gull eggs collected from Chukchi Sea, Bering Sea, and Norton Sound regions.

Figure 17. Principal components analyses for organochlorine pesticides and polychlorinated biphenyls (PCBs) in common murre, thick-billed murre, glaucous gull, and glaucous-winged gull eggs collected at 19 Alaskan colonies in 2008-2009.

Figure 18. Temporal comparisons for St. Lazaria Island common murre and thick-billed murre eggs and St. George thick-billed murre eggs ....

Figure 19. Principal components analyses for organic compounds, mercury, and stable carbon and nitrogen isotopes in common murre, thick-billed murre, glaucous gull, and glaucous-winged gull eggs collected at 19 Alaskan colonies in 2008-2009. 50

\section{List of Appendices}

Appendix 1. A typical egg collecting kit used to mail supplies and safely transport murre and gull eggs for this study......

Appendix 2. Murre and gull egg samples banked in the Marine ESB in Charleston, South Carolina, that were used for polybrominated diphenyl ether, polychlorinated biphenyl, organochlorine pesticide, total mercury, and carbon and nitrogen stable isotope analyses ......... 62

Appendix 3. Hg levels and stable $\delta^{15} \mathrm{~N}, \delta^{13} \mathrm{C}$ isotopes in murre and gull eggs.......................... 65

Appendix 4. Hg isotopes measured in common and thick-billed murre eggs ......................... 70

Appendix 5. Lipids and organochlorine pesticide mass fractions in murre egg control material compared to consensus values and maximum limits of detection ......................................... 73

Appendix 6. Brominated diphenyl ether and polychlorinated biphenyl mass-fractions in murre egg control material compared to consensus values and maximum limits of detection 74 
Appendix 7. Lipids and organochlorine pesticide mass fractions in unidentified murre eggs collected at Cape Lisburne, Alaska in 2009............................................................................. 76

Appendix 8. Lipids and organochlorine pesticide mass fractions in thick-billed murre eggs collected at Little Diomede Island, Alaska in 2008. 77

Appendix 9. Lipids and organochlorine pesticide mass fractions in common murre eggs collected

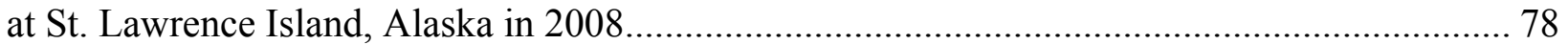

Appendix 10. Lipids and organochlorine pesticide mass fractions in thick-billed murre eggs collected at St. Lawrence Island, Alaska in 2008 ................................................................... 79

Appendix 11. Lipids and organochlorine pesticide mass fractions in common murre eggs

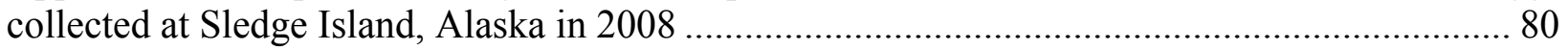

Appendix 12. Lipids and organochlorine pesticide mass fractions in common murre eggs

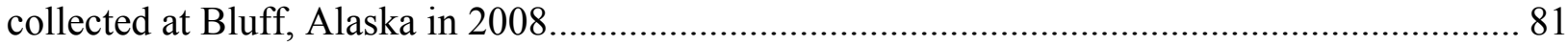

Appendix 13. Lipids and organochlorine pesticide mass fractions in common murre eggs

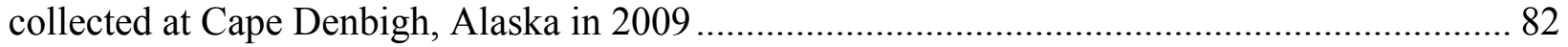

Appendix 14. Lipids and organochlorine pesticide mass fractions in thick-billed murre eggs

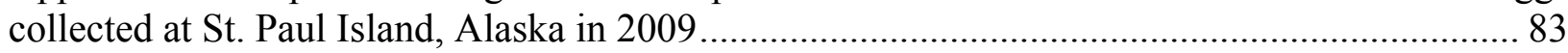

Appendix 15. Lipids and organochlorine pesticide mass fractions in thick-billed murre eggs

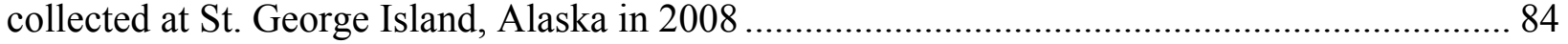

Appendix 16. Lipids and organochlorine pesticide mass fractions in common murre eggs

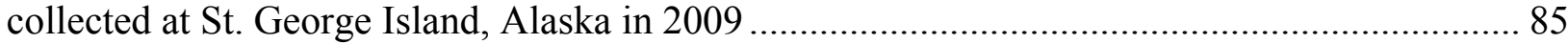

Appendix 17. Lipids and organochlorine pesticide mass fractions in common murre eggs

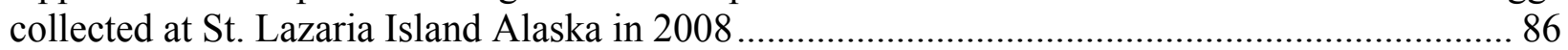

Appendix 18. Lipids and organochlorine pesticide mass fractions in thick-billed murre eggs

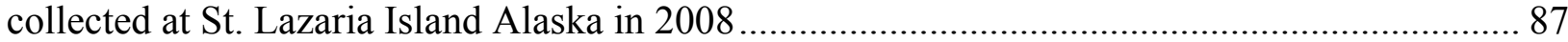

Appendix 19. Lipids and organochlorine pesticide mass fractions in glaucous gull eggs collected

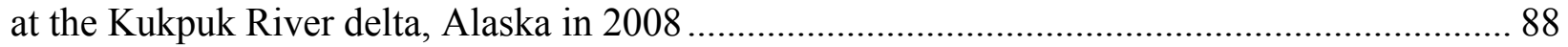

Appendix 20. Lipids and organochlorine pesticide mass fractions in glaucous gull eggs collected

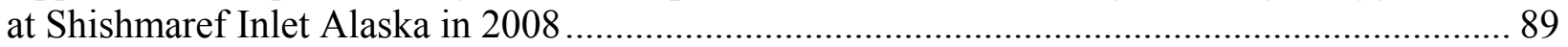

Appendix 21. Lipids and organochlorine pesticide mass fractions in glaucous gull eggs collected at Brevig Mission, Alaska in 2009....................................................................................... 90

Appendix 22. Lipids and organochlorine pesticide mass fractions in glaucous gull eggs collected at the Sinuk River delta, Alaska in 2008. 91 
Appendix 23. Lipids and organochlorine pesticide mass fractions in glaucous gull eggs collected at Safety Sound, Alaska in 2008

Appendix 24. Lipids and organochlorine pesticide mass fractions in glaucous gull eggs collected at Bluff, Alaska in 2008 93

Appendix 25. Lipids and organochlorine pesticide mass fractions in glaucous gull eggs collected at Carolyn Island, Alaska in 2008. 94

Appendix 26. Lipids and organochlorine pesticide mass fractions in glaucous gull eggs collected at Cape Darby, Alaska in 2008 95

Appendix 27. Lipids and organochlorine pesticide mass fractions in glaucous gull eggs collected at Shaktoolik, Alaska in 2008. 96

Appendix 28. Lipids and organochlorine pesticide mass fractions in glaucous gull eggs collected at Shaktoolik, Alaska in 2009. 97

Appendix 29. Lipids and organochlorine pesticide mass fractions in glaucous gull eggs collected at Stuart Island, Alaska in 2009. 98

Appendix 30. Lipids and organochlorine pesticide mass fractions in glaucous-winged gull eggs collected at Aiktak Island, Alaska in 2009 99

Appendix 31. Brominated diphenyl ether and polychlorinated biphenyl mass fractions in unidentified murre eggs collected at Cape Lisburne, Alaska in 2009 100

Appendix 32. Brominated diphenyl ether and polychlorinated biphenyl mass fractions in thickbilled murre eggs collected at Little Diomede Island, Alaska in 2008 102

Appendix 33. Brominated diphenyl ether and polychlorinated biphenyl mass fractions in common murre eggs collected at St. Lawrence Island, Alaska in 2008 104

Appendix 34. Brominated diphenyl ether and polychlorinated biphenyl mass fractions in thickbilled murre eggs collected at St. Lawrence Island, Alaska in 2008 106

Appendix 35. Brominated diphenyl ether and polychlorinated biphenyl mass fractions in common murre eggs collected at Sledge Island, Alaska in 2008 108

Appendix 36. Brominated diphenyl ether and polychlorinated biphenyl mass fractions in common murre eggs collected at Bluff, Alaska in 2008. 110

Appendix 37. Brominated diphenyl ether and polychlorinated biphenyl mass fractions in common murre eggs collected at Cape Denbigh, Alaska in 2009 112

Appendix 38. Brominated diphenyl ether and polychlorinated biphenyl mass fractions in common murre eggs collected at St. Paul Island, Alaska in 2009. 114 
Appendix 39. Brominated diphenyl ether and polychlorinated biphenyl mass fractions in thickbilled murre eggs collected at St. George Island, Alaska in 2008 116

Appendix 40. Brominated diphenyl ether and polychlorinated biphenyl mass fractions in common murre eggs collected at St. George Island, Alaska in 2009 118

Appendix 41. Brominated diphenyl ether and polychlorinated biphenyl mass fractions in common murre eggs collected at St. Lazaria Island, Alaska in 2008 .

Appendix 42. Brominated diphenyl ether and polychlorinated biphenyl mass fractions in thickbilled murre eggs collected at St. Lazaria Island, Alaska in 2008. 122

Appendix 43. Brominated diphenyl ether and polychlorinated biphenyl mass fractions in glaucous gull eggs collected at the Kukpuk River delta, Alaska in 2008 124

Appendix 44. Brominated diphenyl ether and polychlorinated biphenyl mass fractions in glaucous gull eggs collected at Shishmaref Inlet, Alaska in 2008. 126

Appendix 45. Brominated diphenyl ether and polychlorinated biphenyl mass fractions in glaucous gull eggs collected at Brevig Mission, Alaska in 2009 128

Appendix 46. Brominated diphenyl ether and polychlorinated biphenyl mass fractions in glaucous gull eggs collected at the Sinuk River delta, Alaska in 2008 130

Appendix 47. Brominated diphenyl ether and polychlorinated biphenyl mass fractions in glaucous gull eggs collected at Safety Sound, Alaska in 2008 132

Appendix 48. Brominated diphenyl ether and polychlorinated biphenyl mass fractions in glaucous gull eggs collected at Bluff, Alaska in 2008. 134

Appendix 49. Brominated diphenyl ether and polychlorinated biphenyl mass fractions in glaucous gull eggs collected at Carolyn Island, Alaska in 2008. 136

Appendix 50. Brominated diphenyl ether and polychlorinated biphenyl mass fractions in glaucous gull eggs collected at Cape Darby, Alaska in 2008 138

Appendix 51. Brominated diphenyl ether and polychlorinated biphenyl mass fractions in glaucous gull eggs collected at Shaktoolik South, Alaska in 2008. 140

Appendix 52. Brominated diphenyl ether and polychlorinated biphenyl mass fractions in glaucous gull eggs collected at Shaktoolik South, Alaska in 2009. 142

Appendix 53. Brominated diphenyl ether and polychlorinated biphenyl mass fractions in glaucous gull eggs collected at Stuart Island, Alaska in 2009 144

Appendix 54. Brominated diphenyl ether and polychlorinated biphenyl mass fractions in glaucous-winged gull eggs collected at Aiktak Island, Alaska in 2009 146 


\section{Acknowledgements}

We would like to thank Sandy Tahbone and Eric (Bill) Trigg, Kawerak Inc., Nome, for coordinating the Norton Sound - Bering Strait egg collecting efforts, and receiving, storing, and shipping the eggs to Homer. Their help was instrumental in the project's success. We would also like to thank the following people for collecting eggs in 2006-2009: Archie Adam (Brevig Mission), Arthur Ahkinga (Diomede), Austin Ahmasuk (Nome), Jane Dolliver (University of Washington), Jack Fagerstrom (Golovin), Andrew Foxie, Sr. (Stebbins), Dylan Iya (Savoonga), Clyde Jackson (Shaktoolik), Dwayne Johnson, Sr. (Unalakleet), Elijah Lane (Point Hope), Eric Larson (Nome), Nick Lekanof (St. George), Allyson Larned (USFWS-AMNWR), Peter Lekanof (St. George), Peter Lockuk, Sr. (Togiak), Jack Lorrigan (Sitka), Rob Macdonald (USFWSAMNWR), Andy Malavansky (St. George), Gary Merculief (St. George), Mike McClintock (USFWS-AMNWR), Rachael Orben (USFWS-AMNWR), Albert Paimiut (Hooper Bay), Julia Parrish (University of WA), Monica Parsons (USGS-BRD), Slade Sapora (USFWS-AMNWR), Leslie Slater (USFWS-AMNWR), T. Sparks, (Nome), Nick Tanape, Sr. (Nanwalek), Stanley Tocktoo (Shishmaref), Greg Thomson (USFWS-AMNWR), Lily Tuzroyluke (Point Hope), Tim Van Nus (USGS-BRD), Norman Vlasoff (Tatilek), Brandon Waghiyi (Savoonga) and several unidentified residents of Point Hope. The project could not have been conducted without their help. We would also like to thank Stephen Long and Michele Schantz (NIST) and Tom Van Pelt (NPRB) for their critical review of this report. North Pacific Research Board Project 822 funded part of this study.

\section{Disclaimer}

Any mention of commercial products is for information only; it does not imply recommendation or endorsement by NIST. 


\section{Abbreviations}

\begin{tabular}{|c|c|}
\hline AMAP & Arctic Monitoring and Assessment Programme \\
\hline ANOVA & Analysis of Variance \\
\hline BFR & Brominated flame retardant \\
\hline $\mathrm{C}$ & Carbon \\
\hline $\mathrm{CH}_{2} \mathrm{Cl}_{2} ; \mathrm{DCM}$ & Dichloromethane (Methylene chloride) \\
\hline CFIRMS & Continuous flow isotope ratio mass spectrometry \\
\hline $\mathrm{CM}$ & Control material \\
\hline COMU & Common murre, Uria aalge \\
\hline DDD & Dichlorodiphenyldichloroethane \\
\hline DDE & Dichlorodiphenyldichloroethylene \\
\hline DDT & Dichlorodiphenyltrichloroethane \\
\hline $\mathrm{DOC}$ & Dissolved organic carbon \\
\hline EI & Electron impact \\
\hline ESB & Environmental Specimen Bank \\
\hline EPA & Environmental Protection Agency \\
\hline $\mathrm{GC}$ & Gas chromatography \\
\hline GLGU & Glaucous gull, Larus hyperboreus \\
\hline GWGU & Glaucous-winged gull, Larus glaucescens \\
\hline HBCDD & Hexabromocyclododecane \\
\hline $\mathrm{HCB}$ & Hexachlorobenzene \\
\hline $\mathrm{HCH}$ & Hexachlorocyclohexane \\
\hline $\mathrm{HCl}$ & Hydrochloric acid \\
\hline HDBP & Halogenated dimethyl bypyrrole \\
\hline $\mathrm{Hg}$ & Mercury \\
\hline $\mathrm{HNO}_{3}$ & Nitric acid \\
\hline IAEA & International Atomic Energy Agency \\
\hline ID-CV-ICPMS & Isotope dilution cold vapor inductively coupled plasma mass spectrometry \\
\hline $\mathrm{iHG}$ & Inorganic mercury \\
\hline IPREM & Institut Pluridisciplinaire de Recherche sur l'Environnement et les Materiaux \\
\hline LOD & Limit of detection \\
\hline LOQ & Limit of quantitation \\
\hline $\mathrm{LN}_{2}$ & Liquid nitrogen \\
\hline MANOVA & Multivariate analysis of variance \\
\hline MDF & Mass dependent fractionation \\
\hline $\mathrm{MeHg}$ & Monomethylymercury \\
\hline MIF & Mass independent fractionation \\
\hline MS & Mass spectrometry \\
\hline $\mathrm{N}$ & Nitrogen \\
\hline $\mathrm{NCI}$ & Negative chemical ionization \\
\hline NIST & National Institute of Standards and Technology \\
\hline NPRB & North Pacific Research Board \\
\hline $\mathrm{OC}$ & Organic carbon \\
\hline PBDE & Polybrominated diphenyl ether \\
\hline $\mathrm{PC}$ & Principal component \\
\hline PCA & Principal components analysis \\
\hline PCB & Polychlorinated biphenyl \\
\hline PFE & Pressurized fluid extraction \\
\hline POPs & Persistent Organic Pollutants \\
\hline PTV & Programmed temperature vaporization \\
\hline RSD & Relative standard deviation \\
\hline SEC & Size exclusion chromatography \\
\hline SIHERL & Stable Isotope Hydrology and Ecology Research Laboratory \\
\hline SIM & Selected ion monitoring \\
\hline $\mathrm{SnCl}_{2}$ & Tin chloride \\
\hline
\end{tabular}




$\begin{array}{ll}\text { SPE } & \text { Solid phase extraction } \\ \text { SRM } & \text { Standard reference material } \\ \text { STAMP } & \text { Seabird Tissue Archival and Monitoring Project } \\ \text { TBMU } & \text { Thick-billed murre, Uria lomvia } \\ \text { THg } & \text { Total mercury } \\ \text { T1 } & \text { Thallium } \\ \text { TOC } & \text { Total organic carbon } \\ \text { UAMN } & \text { University of Alaska Museum of the North } \\ \text { UNMU } & \text { Unidentified murre, Uria spp. } \\ \text { USFWS-AMNWR } & \text { United States Fish and Wildlife Service - Alaska Maritime National Wildlife Refuge } \\ \text { VPDB } & \text { Vienna Pee Dee Belemni }\end{array}$

\section{Abstract}

Since 1999, the Seabird Tissue Archival and Monitoring Project (STAMP) has collected, banked, and analyzed seabird eggs using established protocols to monitor chlorinated pesticides, polychlorinated biphenyls (PCBs), brominated flame retardants, and mercury in Alaska's marine environments. In 2006 and 2008-2009, 594 clutches of murre and gull eggs were obtained and banked at the Marine Environmental Specimen Bank, National Institute of Standards and Technology (NIST), using established protocols. During 2008-2010, 118 of the clutches from 13 Norton Sound - Bering Strait seabird colonies and 6 other nesting locations in the Bering and Chukchi seas and Gulf of Alaska were analyzed by NIST at the Hollings Marine Laboratory, Charleston, South Carolina for mercury and persistent organic pollutants. Mercury isotope analyses were run at the Equipe de Chimie Analytique BioInorganique et Environnement facility in Pau, France, and the Stable Isotope Hydrology and Ecology Research Laboratory in Saskatoon, Saskatchewan, ran stable carbon and nitrogen isotope analyses. Most bromated flame retardants were below detection limits. Polychlorinated biphenyl levels in the Norton Sound murre eggs were similar to levels found at other colonies in the region, but total mercury and some chlorinated pesticides were higher, compared to these locations. Most contaminant levels in Norton Sound gull eggs were also higher, but some chlorinated pesticides and polychlorinated biphenyls were lower, compared to the other colonies. Mercury and stable carbon and nitrogen isotope gradients indicated that Norton Sound has a unique mercury regime that is related to terrestrial sources of this metal. Mass independent fractionation is lower at northern latitudes, where sea-ice cover inhibits photoreduction of mercury, but it was also low in Norton Sound and the northern Bering Sea, indicating that ice was not the only factor influencing mercury fractionation patterns in these regions. 


\section{Introduction}

The Seabird Tissue Archival and Monitoring Project (STAMP) is a collaborative, long-term program of the U.S. Fish and Wildlife Service Alaska Maritime National Wildlife Refuge (USFWS-AMNWR) and the National Institute of Standards and Technology (NIST) to monitor persistent organic pollutants (POPs), mercury, and other contaminants in Alaskan marine environments using seabird eggs. The purpose of STAMP is to monitor long-term trends in environmental quality by (1) collecting seabird tissues (primarily eggs) at seabird colonies without inadvertently contaminating them, (2) processing and banking the samples under conditions that ensure chemical stability during long-term (decadal) storage, and (3) analyzing subsamples of the stored material for anthropogenic contaminants. (see Roseneau et al. 2008 for more project history details). Eggs, collected using established protocols (Rust et al. 2010), are shipped to AMNWR's laboratory in Homer, Alaska, where the contents are removed, homogenized, and transferred to labeled Teflon and polypropylene containers before being frozen and shipped to NIST's Marine Environmental Specimen Bank (Marine ESB) at the Hollings Marine Laboratory in Charleston, South Carolina, for long-term (decadal) storage in stainless steel liquid nitrogen $\left(\mathrm{LN}_{2}\right)$ vapor freezers at $-150{ }^{\circ} \mathrm{C}$. Dried egg shells are sent to the University of Alaska Museum of the North (UAMN) in Fairbanks, Alaska, for safekeeping.

In 2002, STAMP received North Pacific Research Board (NPRB) funding to analyze a series of previously banked murre (Uria spp.) and gull (Larus spp.) eggs from several colonies in the Bering and Chukchi seas and Gulf of Alaska for chlorinated pesticides, polychlorinated biphenyls (PCBs), polybrominated diphenyl ethers (PBDEs; a group of brominated flame retardants or BFRs), organotins (butyltins), and mercury (Hg). The 2002 study (NPRB Project 534) found relatively high levels of $\mathrm{Hg}$ in common murre (U. aalge) eggs from three Norton Sound colonies (Sledge Island, Bluff, and Cape Denbigh) and differences in organic contaminant patterns in this northeastern Bering Sea region (Roseneau et al. 2008).

Murre and gull eggs are important dietary items in northwestern Alaska, where residents of the region traditionally harvest and consume large numbers of them annually (Ahmasuk and Trigg 2007; A. Ahmasuk, pers. comm.). For example, in 1995, people living in Nome collected at least 7,404 murre and 1,259 gull eggs, and people living in Brevig Mission, White Mountain, and Unalakleet harvested 2,533 gull eggs (see the Alaska Department of Fish and Game Subsistence Division Community Subsistence Information System web site at http://www.adfg.alaska.gov/sb/CSIS/index.cfm).

Given the high Hg levels found in Norton Sound during NPRB Project 534 and the importance of murre and gull eggs to residents of the area, there was a need to obtain more information on the distribution this potentially harmful contaminant in the region. The current study, implemented in 2008, was designed to expand common murre and glaucous gull (Larus hyperboreus) egg sampling activities in and near Norton Sound; analyze the eggs for $\mathrm{Hg}$, chlorinated pesticides, PCBs, and BFRs (PBDEs); investigate $\mathrm{Hg}$ isotope patterns throughout the region; and test the hypotheses that: 1) Hg levels in Norton Sound common murre eggs were high and relatively consistent over time; 2) Hg levels in Norton Sound glaucous gull eggs were higher than those found outside this region; 3) Norton Sound Hg isotope patterns differed from more distant nesting locations; and 4) POP levels in Norton Sound murre and gull eggs did not differ from colonies outside this northeastern Bering Sea embayment. 
Various geologic and environmental matrices have been characterized to inventory the isotope signatures of different types of source materials, and document the ranges in $\mathrm{Hg}$ isotope ratios observed in these materials around the globe (Yin et al., 2010). Isotope ratios are reported using delta $(\delta)$ notation, which references all measured isotope ratios to a universally used delta standard, and provides a relative measure of the degree of $\mathrm{Hg}$ mass-dependent fractionation (MDF) (Blum and Bergquist, 2007). Variation in isotope ratios that is unrelated to isotope mass is termed mass-independent fractionation (MIF), reported using capital delta $(\Delta)$. Host rocks, Hg-bearing minerals, hydrothermal fields, and sediments and soils generally exhibit negative to slightly positive MDF and little to no MIF (Yin et al., 2010), with the exception of some soils and peat that were reported to have slightly negative or slightly positive MIF (Feng et al., 2010; WenFang et al., 2011). Coal also exhibits negative MDF, and negative to slightly positive MIF (Biswas et al., 2008). In contrast to terrestrial systems, measurements of aquatic biota display distinctly positive MIF, and MDF that ranges from negative to positive in freshwater systems (Bergquist and Blum, 2007; Gantner et al., 2009; Laffont et al., 2009; Perrot et al., 2010; Senn et al., 2010) and have tendencies toward more consistently positive values in marine systems (Point et al., 2011; Senn et al., 2010).

Several studies have successfully used isotope signatures to trace $\mathrm{Hg}$ sources and fates in the environment (Estrade et al., 2011; Feng et al., 2010; Foucher et al., 2009; Gehrke et al., 2011; Liu et al., 2011). These studies have typically focused on soils and sediments at scales of tens of kilometers in order to assess localized environmental impacts or study fluvial $\mathrm{Hg}$ transport. But applying a similar approach on larger scales to help inform regional and global assessments is challenging. In part, this is because $\mathrm{Hg}$ undergoes many different biotic and abiotic reactions that can further fractionate and alter isotope source signatures after $\mathrm{Hg}$ enters the environment, thereby complicating the use of $\mathrm{Hg}$ isotope systems for source tracking. Isotope fractionation has been observed in numerous physical, chemical, and biological transformations of $\mathrm{Hg}$, including redox reactions (photolysis, microbial, or chemical pathways), evaporation/condensation, volatilization, methlyation, and absorption (Yin et al., 2010). Photoreduction of $\mathrm{Hg}$ species is considered to be the most important mechanism responsible for the large MIF that is observed in aquatic systems (Bergquist and Blum, 2007). Although dynamic processes of fractionation are a complicating factor for source apportionment, they provide a valuable opportunity to use fractionation patterns to trace specific transformations and reactions in the environment and estimate their rates (Sonke, 2011). More controlled experimental studies are needed to better characterize the reactions that fractionate $\mathrm{Hg}$ so these processes can be unraveled from native isotope source signatures.

The objective of the current work was to collect and refine information on the overall distribution of $\mathrm{Hg}$ and POPs in murre and gull eggs in the Norton Sound - Bering Strait region, and determine if $\mathrm{Hg}$ levels were correlated with estuarine wetlands, river outflows, and historical gold mining activities.

The first part of the objective was met by collecting 261 clutches of murre and gull eggs from 13 nesting colonies in the study area and 6 locations outside of it in 2008-2009, and analyzing subsets of them for $\mathrm{Hg}, \mathrm{PCBs}$, chlorinated pesticides, and BFRs (PBDEs; see Appendix 2). 
The second part of the objective was met by conducting $\mathrm{Hg}$ isotope analyses and determining if $\mathrm{Hg}$ fractionation patterns differed among the Norton Sound colonies and other nesting locations.

\section{Methods}

\section{$\underline{\text { Study Area and Sampling Sites }}$}

During 2008-2009, 144 murre eggs, 111 clutches of glaucous gull eggs (one is believed to be from a common eider), and 6 clutches of glaucous-winged gull (L. glaucescens) eggs were collected from 19 nesting colonies in the Chukchi and Bering seas and Gulf of Alaska (Table 1). Rural residents working under the direction of Kawerak Inc. in Nome obtained 87 of the murre eggs and 95 of the gull clutches from 13 sites in the Norton Sound - Bering Strait study area (Table 1 and Figs. 2 and 3), and AMNWR biologists and the St. George Traditional and Native Village of Point Hope councils collected the remaining eggs from 6 more distant nesting locations (Table 1 and Fig. 1; Cape Lisburne, the Kukpuk River delta, and St. Paul, St. George, Aiktak, and St. Lazaria islands). Eggs were not obtained in 2007, but in 2006, 134 common murre eggs, 44 thick-billed murre eggs, 127 clutches of glaucous-winged gull eggs, and 34 clutches of glaucous gull eggs were collected at 18 Alaskan sites and 1 in Washington State (Table 2). Sampling at Middleton Island was designed to test how laying order in gull eggs and embryo development in murre eggs might affect contaminant levels. However, the 2006 samples have not been analyzed yet, and only data from a subset of the 2008-2009 eggs are summarized in this report. 


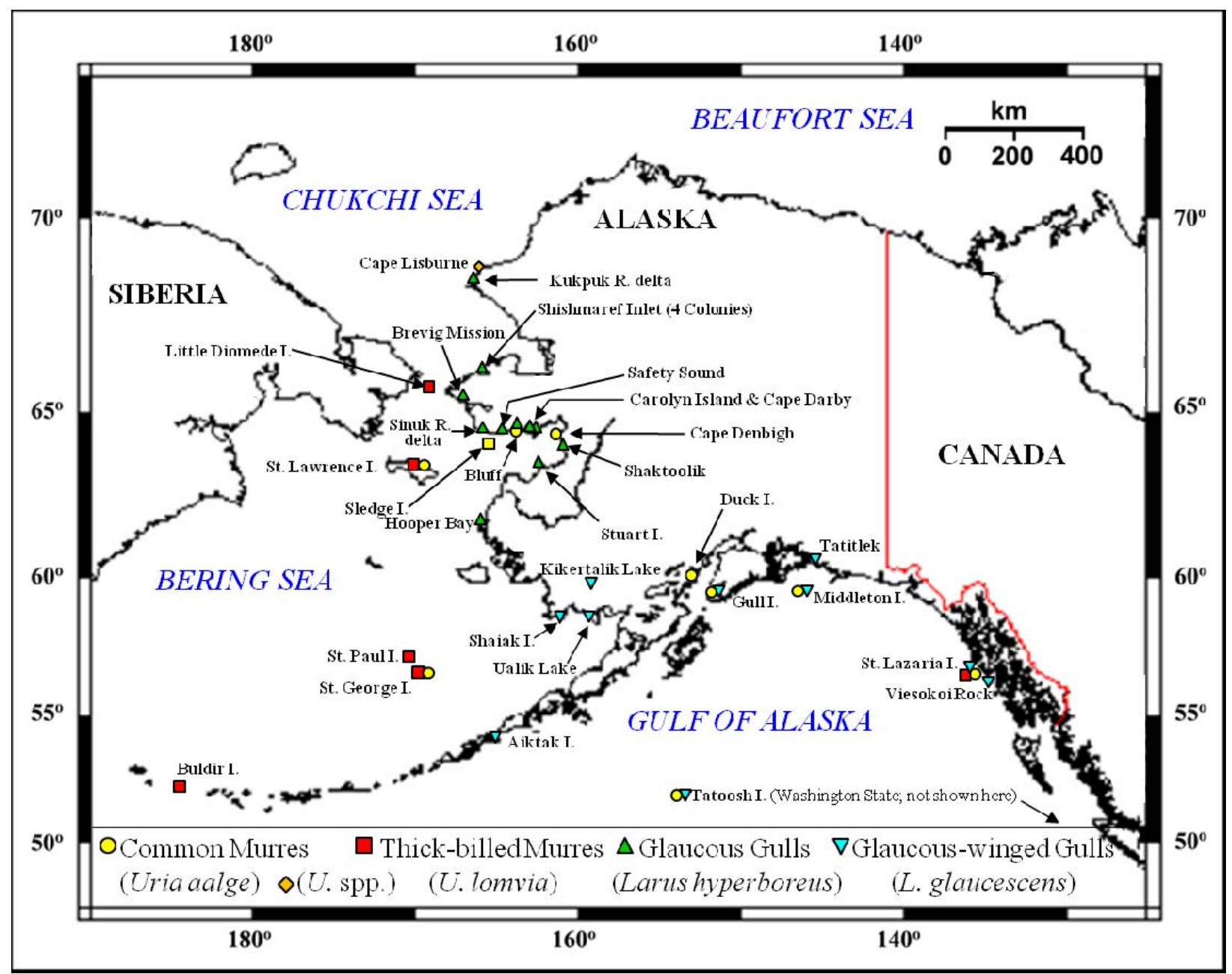

Figure 1. The 2006-2009 Seabird Tissue Archival and Monitoring Project (STAMP) seabird egg collecting sites. 
Table 1. The 2008-2009 Seabird Tissue Archival and Monitoring Project (STAMP) seabird egg collecting sites (also see Figs. 1-3).

Colony

Species (eggs, clutches)

Inside the Norton Sound - Bering Strait Area

Shishmaref Inlet

Little Diomede Island

Brevig Mission

Sinuk River delta

Sledge Island

Safety Sound

Bluff

Bluff

Carolyn Island (Golovin Bay)

Cape Darby

Cape Denbigh

Shaktoolik

Stuart Island

St. Lawrence Island

St. Lawrence Island

Total Sampling Sites: 13
Glaucous Gull (27 eggs, 12 clutches) Thick-billed Murre (15 eggs, 15 clutches) Glaucous Gull (16 eggs, 11 clutches) Glaucous Gull (15 eggs, 13 clutches) Common Murre (15 eggs, 15 clutches) Glaucous Gull (17 eggs, 12 clutches) * One believed to be from Common Eider!

Common Murre (15 eggs, 15 clutches) Glaucous Gull (4 eggs, 4 clutches) Glaucous Gull (12 eggs, 12 clutches) Glaucous Gull (15 eggs, 12 clutches) Common Murre (12 eggs, 12 clutches) Glaucous Gull (16 eggs, 12 clutches) Glaucous Gull (10 eggs, 7 clutches) Common Murre (15 eggs, 15 clutches) Thick-billed Murre (15 eggs, 15 clutches)

Total Species Sampled: 3 Total Murre Eggs: 87 Total Gull Clutches: 95

Outside the Norton Sound - Bering Strait Study Area

Cape Lisburne

Kukpuk River delta

St. Paul Island

St. George Island

St. George Island

Aiktak Island

St. Lazaria Island

St. Lazaria Island

Total Sampling Sites: 6
Unidentified Murre (7 eggs, 7 clutches) Glaucous Gull (16 eggs, 16 clutches) Thick-billed Murre (8 eggs, 8 clutches) Common Murre (12 eggs, 12 clutches) Thick-billed Murre (15 eggs, 15 clutches) Glaucous-winged Gull (8 eggs, 6 clutches) Common Murre (10 eggs, 10 clutches) Thick-billed Murre (5 eggs, 5 clutches)

Total Species Sampled: 4 Total Murre Eggs: 57 Total Gull Clutches: 22 
Table 2. Clutches of seabird eggs banked by the Seabird Tissue Archival and Monitoring Project (STAMP) in the Marine Environmental Specimen Bank in Charleston, SC organized in a general southeast to northward pattern. Highlighted cells show the number of clutches that have been analyzed for contaminants.

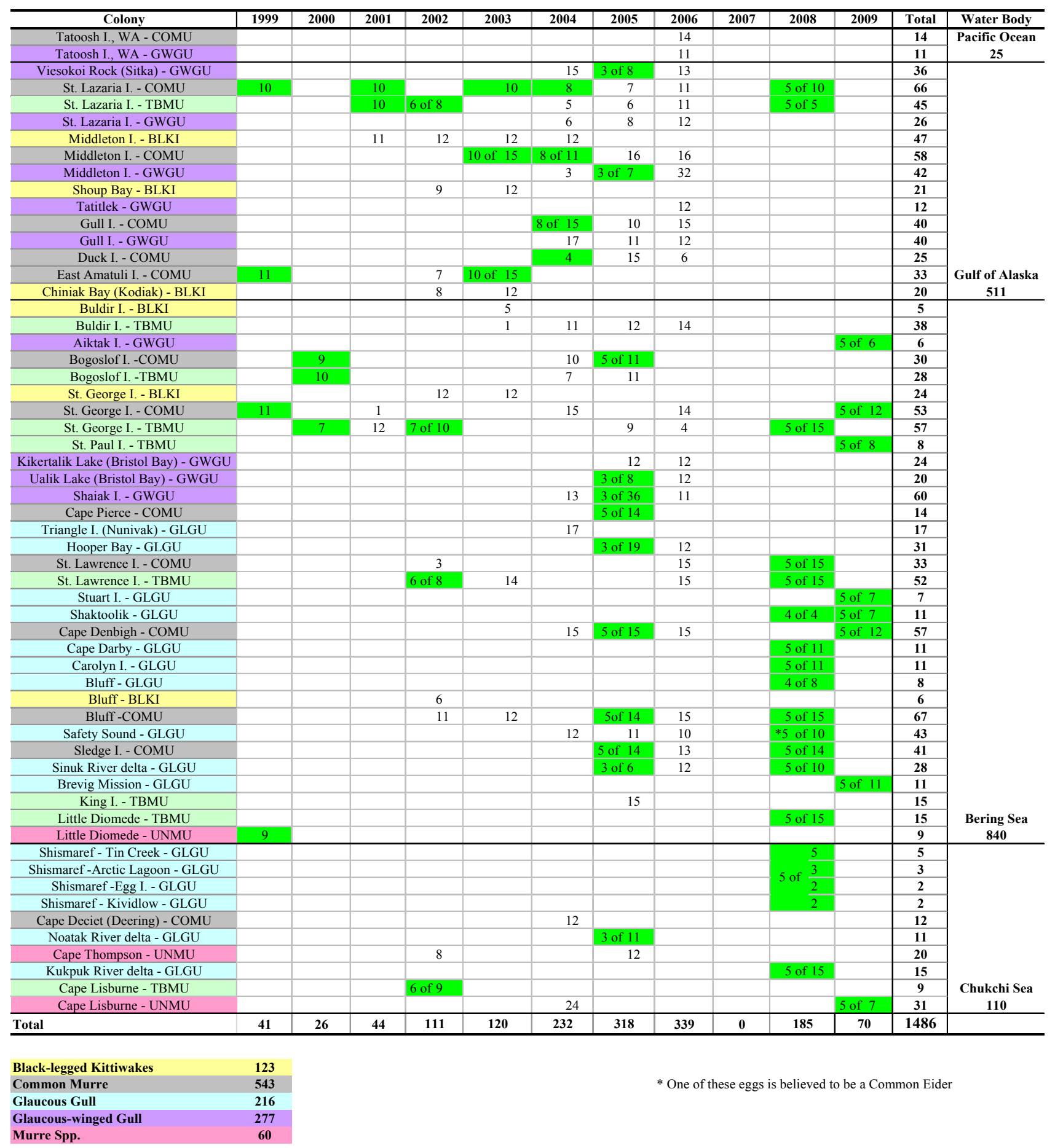




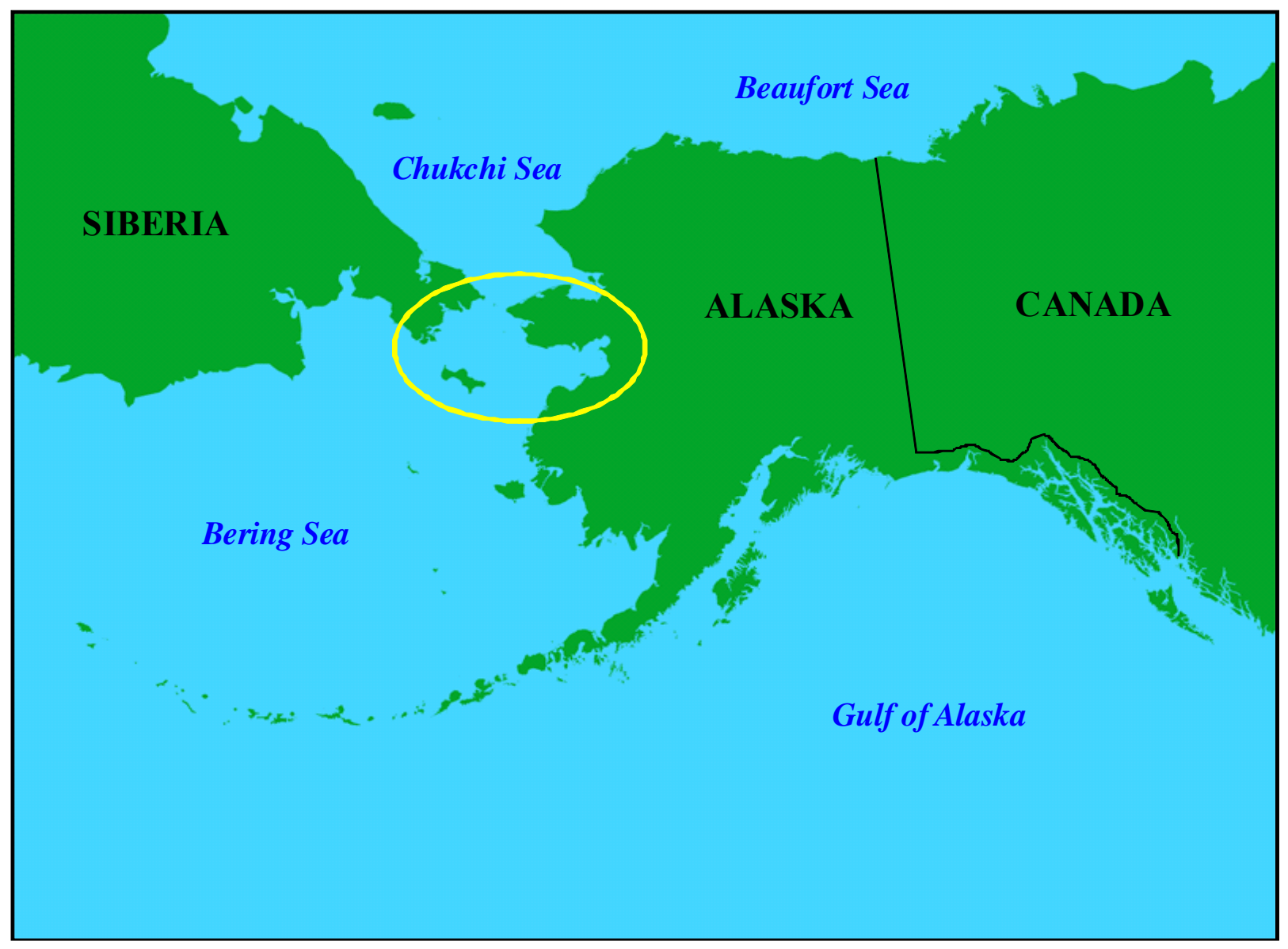

Figure 2. General location of the Norton Sound - Bering Strait study area (yellow oval). 


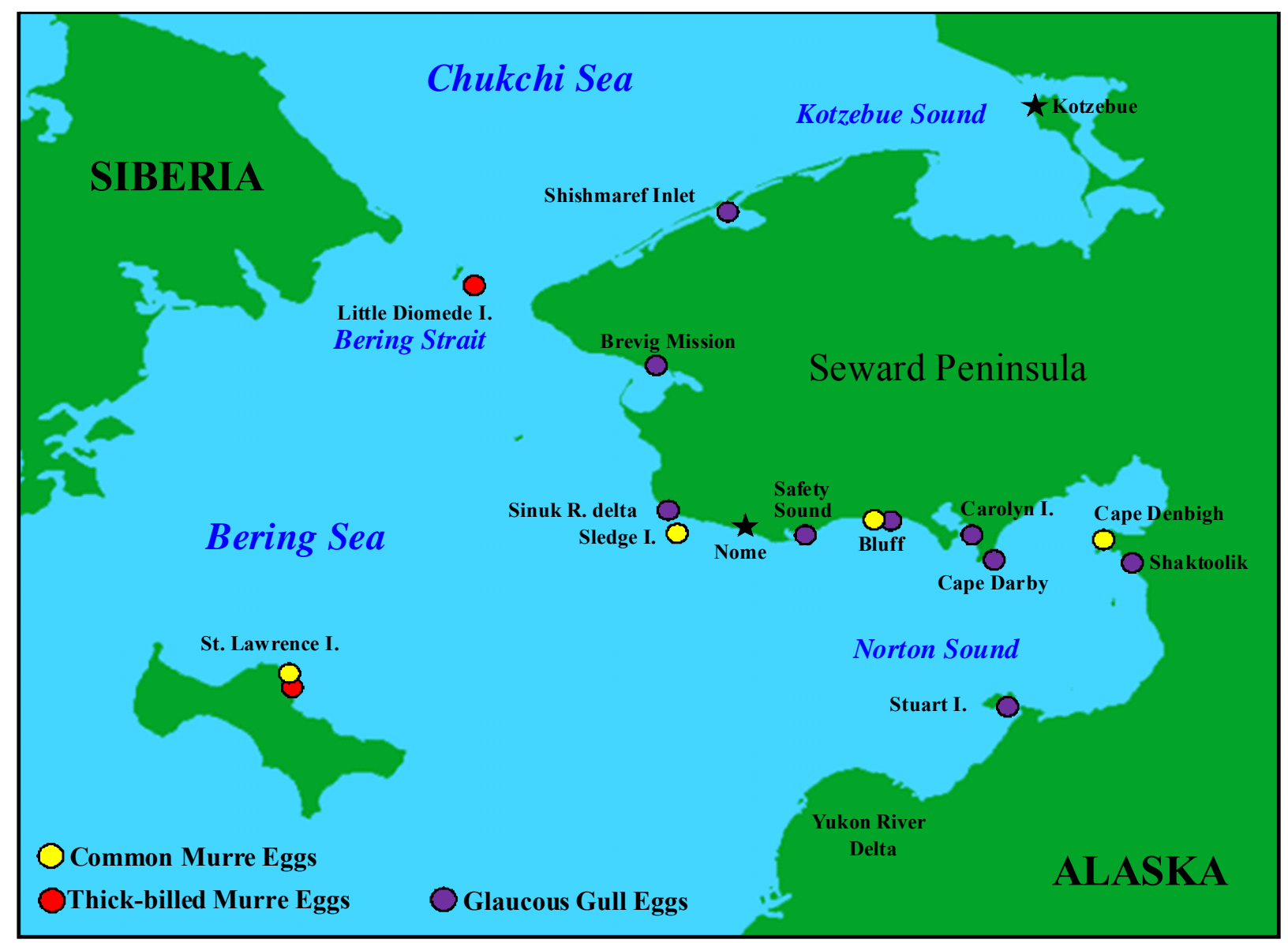

Figure 3. The 13 nesting locations in the Norton Sound - Bering Strait study area where murre and gull eggs were collected in 2008-2009. 


\section{$\underline{\text { Sample Collecting, Processing, and Banking }}$}

All of the murre and gull eggs that we analyzed for the study were collected, processed, and banked using established STAMP protocols (Rust et al. 2010). Kawerak Inc. in Nome organized and coordinated the Norton Sound - Bering Strait collections. Egg collecting kits consisting of 50-quart coolers containing foam rubber layers to protect the samples, collecting supplies, shipping labels, and federal and state scientific collecting permits were mailed to participating residents in the study area (Appendix 1). Additional kits were sent to the colonies outside of the Norton Sound - Bering Strait study area.

Collectors returned the coolers containing the eggs to the AMNWR laboratory in Homer, Alaska, where the samples were refrigerated until they could be processed. Processing included cleaning the eggs with Type 1 distilled water, measuring them (length, width, whole egg mass), breaking/cutting them in half and pouring the contents into chemically cleaned glass measuring cups under a positive pressure laminar flow hood, weighing the cups containing the contents on a digital scale, covering the cups with clean UHV foil (All Foils, Cleveland OH, USA) and homogenizing the contents using a high-speed blender (VirTis, Warminster PA, USA) pipetting the contents into a series of labeled temperature resistant $15 \mathrm{~mL}$ Teflon jars and polypropylene cryovials (Nalgene. Rochester NY, USA), and freezing the samples until they could be shipped to the Marine ESB in Charleston, South Carolina, for long-term (decadal) storage at $-150{ }^{\circ} \mathrm{C}$ in stainless steel liquid nitrogen $\left(\mathrm{LN}_{2}\right)$ vapor freezers. Murre eggs were processed individually and gull eggs from the same clutches were pooled before they were homogenized.

Processed samples were sent to the Marine ESB in $\mathrm{LN}_{2}$ dry shippers. After they were formally entered into the specimen bank's long-term storage system, subsamples were released to NIST chemists for $\mathrm{Hg}$ and POP analyses. Subsamples were also sent to the Stable Isotope Hydrology and Ecology Research Laboratory (SIHERL) in Saskatoon, Saskatchewan, for ${ }^{13} \mathrm{C}$ and ${ }^{15} \mathrm{~N}$ stable isotope analyses. Egg shells were rinsed with Type 1 water, dried, placed in labeled plastic bags, and mailed to the University of Alaska Museum of the North (UAMN) in Fairbanks, Alaska, for long-term storage.

\section{Mercury $(\mathrm{Hg})$ and $\mathrm{Hg}$, Carbon $(\mathrm{C})$ and Nitrogen $(\mathrm{N})$ Isotopes}

\section{Total Hg Levels}

We employed isotope dilution cold vapor inductively coupled plasma mass spectrometry (IDCV-ICPMS) to determine total mercury (THg) levels in the egg samples. This technique has been described elsewhere (Christopher et al. 2001) and is only summarized here. Isotopically enriched ${ }^{201} \mathrm{Hg}$ spike solution (Oak Ridge National Laboratory, USA) was prepared and calibrated using NIST SRM 1641d Mercury in Water standard solution. The spike was added quantitatively to the sample masses to yield an isotopic ratio $\left({ }^{201} \mathrm{Hg} /{ }^{202} \mathrm{Hg}\right)$ that minimized random error propagation. The specific sequences and methods for digestion and addition of the ${ }^{201} \mathrm{Hg}$ spike solution to the 2008 and 2009 batches are described below. The resulting digestant was mixed with a $\mathrm{SnCl}_{2}$ and $\mathrm{HCl}$ reductant solution in a gas-liquid separator that allowed cold vapor transfer of the resulting $\mathrm{Hg}^{0}$ in a stream of argon gas to the inductively 
coupled plasma mass spectrometer (ICPMS) injector. We used a VG Elemental Plasma Quad 3 ICPMS (Windsford, Cheshire, United Kingdom) set at normal power and gas flow rates in its time resolved analysis mode to measure the isotope ratios.

2008 Collections, Batches 1-8: The aliquots that we digested for THg weighed about $0.5 \mathrm{~g}$ each and we weighed them directly into quartz microwave vessels using a three-place analytical balance (Mettler, Toledo OH, USA, Model PG603-S). The vessels contained $1.0 \mathrm{~mL}$ nitric acid (Optima, Fisher Scientific, Suwanee GA, USA), $0.5 \mathrm{~mL}$ hydrogen peroxide (Trace Select, Fluka, Germany), and $0.5 \mathrm{~mL}$ of high purity water. We digested the samples in a Perkin-Elmer (Shelton CT, USA) Multiwave microwave oven at the highest possible temperatures (up to 300 ${ }^{\circ} \mathrm{C}$ ) and pressures (up to $8 \mathrm{MPa}$ ) that was programmed as follows: (1) $100 \mathrm{~W}$ to $600 \mathrm{~W}$ ramp up over $5 \mathrm{~min}$, (2) $5 \mathrm{~min}$ hold at $600 \mathrm{~W}$, and (3) $20 \mathrm{~min}$ hold at $1000 \mathrm{~W}$. After digestion, we transferred the samples to clean containers, diluted them to $10.0 \mathrm{~mL}$ with high purity water, and blended them with aliquots of isotopically enriched mercury $\left({ }^{201} \mathrm{Hg}\right.$ enriched isotopic spike, Oak Ridge National Laboratory, USA) that had been calibrated against NIST SRM 1641d Mercury in Water standard solution. As a final step before running the samples, we diluted them to about $0.5 \mathrm{ng} / \mathrm{g}$ each with high purity water and $2 \%$ mass fraction $\mathrm{HNO}_{3}$ and $2 \%$ mass fraction $\mathrm{HCl}$.

We ran batches 1-8 during 24 February 2010 - 5 March 2010. Each batch consisted of two rotors with a total of twelve vessels containing 10 unknown egg samples, one digest of QC04ERM1 Egg Reference Material 1, and one method blank. QC04-ERM1 is an in-house control material that was made from pooled murre eggs (Vander Pol et al. 2007). It has been analyzed repeatedly for $\mathrm{Hg}$ and has been assigned a reference value. We ran the QC04-ERM1 digest at the beginning and end of each batch for method validation (means are reported). We also ran a mass bias correction sample at the beginning and end of each batch to capture instrumental drift in mass bias and correct the measured $\mathrm{Hg}$ isotopic ratios, as appropriate. Each experiment consisted of two batches run consecutively on the ICPMS.

2009 Collections, Batches 9-10: The aliquots that we digested for THg weighed between about $0.15 \mathrm{~g}$ and $0.3 \mathrm{~g}$ each. We weighed them directly into $35 \mathrm{~mL}$ glass microwave vessels using a five-place analytical balance (Sartorius, Model MC210S), and then spiked them with known quantities of isotopically enriched $\mathrm{Hg}\left({ }^{201} \mathrm{Hg}\right.$ enriched isotopic spike, Oak Ridge National Laboratory, USA) that had been calibrated against NIST SRM 1641d Mercury in Water standard solution. We digested the samples with $1.2 \mathrm{~mL}$ nitric acid (Optima, Fisher Scientific, Suwanee GA USA) and $0.3 \mathrm{~mL}$ hydrogen peroxide (Trace Select, Fluka, Germany) in a CEM (Matthews NC, USA) Discover open-focus microwave oven programmed at $50 \mathrm{~W}$ for $2 \mathrm{~min}$, followed by a $50 \mathrm{~W}$ ramp up for $2 \mathrm{~min}$, followed by a $225 \mathrm{~W}$ hold for 6 min ("Dolphin skin 35" method on the microwave laptop). Maximum temperatures and pressures were $250{ }^{\circ} \mathrm{C}$ and 275 psi, respectively, with typical maximum digestion conditions of $200{ }^{\circ} \mathrm{C}$ and 200 psi. After digestion, we transferred the samples to clean containers and diluted them to about $0.5 \mathrm{ng} / \mathrm{g}$ each with high purity water and $2 \%$ mass fraction $\mathrm{HNO}_{3}$ and $2 \%$ mass fraction $\mathrm{HCl}$ in preparation for running them.

We ran batches 9 to 10 during 16-22 September 2010. Each batch consisted of 20 unknown egg samples, 3 digests of QC04-ERM1 Egg Reference Material 1, and two method blanks. We ran 
3 digests of QC04-ERM1 and 3 mass bias correction samples at the beginning, middle, and end of each batch in order to validate the method and capture instrumental drift in mass bias and correct the measured isotopic ratios, as appropriate. The repeated QC04-ERM1 measurements and triplicate analyses of unknown seabird eggs are listed in Table 3.

Table 3. Hg measurements of QC04-ERM1 Egg Reference Material 1 and blanks (the reference value for QC04-ERM1 is $101 \mathrm{ng} / \mathrm{g} \pm 3 \mathrm{ng} / \mathrm{g}$ wet mass).

\begin{tabular}{|c|c|c|c|c|c|}
\hline Batch \# & Sample & $\begin{array}{l}\text { Measured Hg Value } \pm \\
\text { Expanded Uncertainty (ng/g) }\end{array}$ & DF & $\begin{array}{l}\text { Coverage } \\
\text { Factor } \\
\end{array}$ & Blank (ng) \\
\hline 1 & QC04-ERM1 & $100 \pm 2.1$ & 51 & 2.0 & 0.110 \\
\hline 2 & QC04-ERM1 & $100 \pm 2.1$ & 51 & 2.0 & 0.113 \\
\hline 3 & QC04-ERM1 & $95 \pm 2.0$ & 51 & 2.0 & 0.118 \\
\hline 4 & QC04-ERM1 & $96 \pm 2.0$ & 51 & 2.0 & 0.107 \\
\hline 5 & QC04-ERM1 & $101 \pm 2.1$ & 51 & 2.0 & 0.084 \\
\hline 6 & QC04-ERM1 & $106 \pm 2.2$ & 51 & 2.0 & 0.081 \\
\hline 7 & QC04-ERM1 & $97 \pm 2.1$ & 51 & 2.0 & 0.085 \\
\hline 8 & QC04-ERM1 & $99 \pm 2.1$ & 51 & 2.0 & 0.110 \\
\hline \multirow{3}{*}{9} & QC04-ERM1 & $95 \pm 2.2$ & 35 & 2.0 & 4.03 \\
\hline & QC04-ERM1 & $97 \pm 2.2$ & 38 & 2.0 & \\
\hline & QC04-ERM1 & $97 \pm 2.2$ & 37 & 2.0 & 3.93 \\
\hline \multirow{3}{*}{10} & QC04-ERM1 & $97 \pm 2.1$ & 52 & 2.0 & 0.210 \\
\hline & QC04-ERM1 & $99 \pm 2.1$ & 52 & 2.0 & \\
\hline & QC04-ERM1 & $97 \pm 2.0$ & 52 & 2.0 & 0.220 \\
\hline \multirow{6}{*}{$\begin{array}{l}\text { Seabird } \\
\text { Egg } \\
\text { Triplicate }\end{array}$} & ST09E1398C-1 & $83 \pm 1.3$ & 61 & 2.0 & 0.085 \\
\hline & ST09E1398C-2 & $84 \pm 1.4$ & 61 & 2.0 & 0.085 \\
\hline & ST09E1398C-3 & $83 \pm 1.4$ & 61 & 2.0 & 0.110 \\
\hline & & Mean & St Dev & $\%$ RSD & \\
\hline & QC04-ERM1 & 98 & 2.7 & 2.8 & \\
\hline & ST09E1398C & $83 \pm 1.4$ & 0.50 & 0.60 & \\
\hline
\end{tabular}




\section{Hg Isotopes}

We selected 20 thick-billed murre eggs and 25 common murre eggs from 7 representative colonies and analyzed them for $\mathrm{Hg}$ isotopes (Table 4). We digested $0.6-1.0 \mathrm{~g}$ aliquots of the egg samples in glass vessels using microwave assisted acid digestion (CEM Discover, Matthews NC, USA). Microwave digestion consisted of a multi-stage profile of $50 \mathrm{~W}$ for $2 \mathrm{~min}, 125 \mathrm{~W}$ for 2 min, $200 \mathrm{~W}$ for $2 \mathrm{~min}$, and $250 \mathrm{~W}$ for $8 \mathrm{~min}$. Maximum digestion conditions were 275 psi and $230{ }^{\circ} \mathrm{C}$, and typical conditions were $275 \mathrm{psi}$ and $175^{\circ} \mathrm{C}$. $\mathrm{Hg}$ stable isotopes were measured using a $\mathrm{Nu}$ Plasma multi-collector ICP-MS (Nu Instruments, Wrexham, United Kingdom) at the Institut Pluridisciplinaire de Recherche sur l'Environnement et les Materiaux (IPREM) facility in Pau, France. The isotopes were ${ }^{198} \mathrm{Hg},{ }^{199} \mathrm{Hg},{ }^{200} \mathrm{Hg},{ }^{201} \mathrm{Hg},{ }^{202} \mathrm{Hg}$, and ${ }^{204} \mathrm{Hg}$. The lightest isotope $\left({ }^{198} \mathrm{Hg}\right)$ was used as a reference for ratioing all of the other isotopes. $\mathrm{Hg}$ samples were introduced to the ICP as a cold vapor by mixing them with $3 \% \mathrm{SnCl}_{2} / 10 \% \mathrm{HCl}$ and then letting them react in a custom quartz gas liquid separator using an argon gas flow rate of $40 \mathrm{~mL} / \mathrm{minute}$. Blank subtractions were performed using the "On Peak Zero" method for each mass. Mass bias was corrected using the ${ }^{205} \mathrm{Tl} /{ }^{203} \mathrm{Tl}$ ratio and the exponential mass fractionation law by simultaneously introducing Tl (NIST 997 Thallium Isotopic solution) in a dry aerosol form using a desolvating nebulizer (DSN100, Nu Instruments). We used a standard sample-bracketing system to calculate $\delta$ values (mass dependent fractionation, MDF) relative to the reference standard NIST SRM 3133 Mercury Spectrometric Solution using the following equation:

Equation 1: $\delta^{\mathrm{xxx}} \mathrm{Hg}(\%)=\left[\left(\left({ }^{\mathrm{xxx}} \mathrm{Hg} /{ }^{198} \mathrm{Hg}\right)_{\text {Sample }} /\left({ }^{\mathrm{xxx}} \mathrm{Hg} /{ }^{198} \mathrm{Hg}\right)_{\mathrm{SRM} 3133}\right)-1\right] * 1000$

The mass (xxx) of each isotope ratioed to $\left({ }^{198} \mathrm{Hg} \text {, and }{ }^{\mathrm{xxx}} \mathrm{Hg} /{ }^{198} \mathrm{Hg}\right)_{\text {SRM3133 }}$ represented the average ratio of the two NIST SRM 3133 standards bracketing the samples. NIST SRM 3133 is the universally accepted reference standard currently being used in $\mathrm{Hg}$ isotopic research. As a convention (Blum and Bergquist 2007), we used $\delta^{202} \mathrm{Hg}$ to report MDF. We reported mass independent fractionation (MIF) using the capital delta notation $(\Delta)$ and calculated it using the Biswas et al. (2008) formulas listed below for ranges below 10\%:

Formula 1: $\Delta^{199} \mathrm{Hg}(\%)=\delta^{199} \mathrm{Hg}-\left(\delta^{202} \mathrm{Hg} * 0.2520\right)$

Formula 2: $\Delta^{200} \mathrm{Hg}(\%)=\delta^{200} \mathrm{Hg}-\left(\delta^{202} \mathrm{Hg} * 0.5024\right)$

Formula 3: $\Delta^{201} \mathrm{Hg}(\%)=\delta^{201} \mathrm{Hg}-\left(\delta^{202} \mathrm{Hg} * 0.7520\right)$

The $\Delta^{\mathrm{xx}} \mathrm{Hg}$ notation describes the differences between measured $\delta^{\mathrm{xxx}} \mathrm{Hg}$ and theoretically predicted $\delta^{\mathrm{xxx}} \mathrm{Hg}$ using MDF laws. As a convention, we used the most abundant odd isotope $\left(\Delta^{199} \mathrm{Hg}\right)$ to discuss MIF. Standard-sample bracketing was used and samples were run between $0.25 \mathrm{ng} \mathrm{g}^{-1}$ and $1.5 \mathrm{ng} \mathrm{g}^{-1}(0.25 \mathrm{~V}$ to $2.0 \mathrm{~V}$ for $202 \mathrm{Hg})$.

Analytical batches of murre eggs consisted of 5 eggs followed by 1 sample of UM-Almaden intercomparison Hg Standard and either QC-04ERM01 or SRM 1947. UM-Almaden is the most widely reported secondary standard used to assess inter-laboratory results for $\mathrm{Hg}$ isotope measurements, and measured results agreed well with previously published values (Table 5). There are currently no biological reference materials available that are certified for $\mathrm{Hg}$ isotopes that can be used for matrix-matched inter-laboratory comparison and method validation. As a result, the absolute accuracy of these types of measurements in a given matrix is currently 
difficult to definitively confirm, and therefore data are most suitable for investigating relative trends to investigate environmental processes. To begin to address this deficiency, we measured QC-04ERM01 and SRM 1947 and compared these results to previous measurements made on these materials by other laboratories. Measured 2SD values of QC-04ERM01 and SRM 1947 overlapped with previously reported values (Table 5), supporting the validity of the analytical methodology. Measurement repeatability across batches was similar for UM-Almaden and the two biological reference materials. Complex biological matrices may induce fractionation when the matrix is concentrated enough to impair the efficiency of cold vapor generation (personal observation). To confirm that matrix-induced fractionation bias was not present in our egg samples, QC-04ERM01 was run repeatedly across a range of dilutions equal to the dilutions used for murre egg samples $\left(70 \mathrm{x}\right.$ to $400 \mathrm{x}$; [Hg] from $0.25 \mathrm{ng} \mathrm{g}^{-1}$ to $\left.1.5 \mathrm{ng} \mathrm{g}^{-1}\right)$. No systematic bias was observed in MDF or MIF, confirming that matrix-induced fractionation differences between samples did not affect trends (Table 5). There was also no systematic bias observed for SRM 1947 across the range of dilutions used for this material $\left(250 \mathrm{x}\right.$ to $1000 \mathrm{x} ;[\mathrm{Hg}]$ from $0.25 \mathrm{ng} \mathrm{g}^{-1}$ to $1.0 \mathrm{ng} \mathrm{g}^{-1}$ ).

Table 4. Murre eggs from representative colonies that were analyzed for $\mathrm{Hg}$ isotopes.

Species (eggs)

Little Diomede Island

Sledge Island

Bluff

Cape Denbigh

St. Lawrence Island

St. Lawrence Island

St. George Island

St. Lazaria Island

St. Lazaria Island

Total Sampling Sites: 7
Thick-billed Murre (5 eggs)

Common Murre (5 eggs)

Common Murre (5 eggs)

Common Murre (5 eggs)

Common Murre (5 eggs)

Thick-billed Murre (5 eggs)

Thick-billed Murre (5 eggs)

Common Murre (5 eggs)

Thick-billed Murre (5 eggs)

Total Common Murre Eggs: 25

Total Thick-billed Murre Eggs: 20 
Table 5. Quality control sample mercury isotope values compared to previously reported measurements (all values are reported relative to NIST SRM 3133 Mercury Standard Solution). Data were obtained by running the samples concurrently with unknowns and reference materials and reported as mean \pm 2 SD. Four digests of in-house QC-04ERM01 Murre Egg Control Material and 5 digests of NIST SRM 1947 Lake Michigan Fish Tissue were prepared. Samples sizes reflect analytical repeats prepared from digests and stock solutions. Additional quality control samples were run both before and after the batches containing the murre eggs were run to validate the methods (7 aliquots of QC-04ERM01, 5 aliquots of SRM 1947, and 15 aliquots of UM-Almaden).

\begin{tabular}{|c|c|c|c|c|c|c|c|c|c|c|}
\hline $\begin{array}{c}\text { Reference } \\
\text { Material }\end{array}$ & $\underset{(\mathrm{ng} / \mathrm{g})}{\mathrm{Hg}}$ & & $\mathbf{N}$ & $\begin{array}{c}\delta^{199} \mathrm{Hg} \\
(\% \text { o) }\end{array}$ & $\begin{array}{c}\delta^{200} \mathrm{Hg} \\
(\%)\end{array}$ & $\begin{array}{c}\delta^{201} \mathrm{Hg} \\
(\%)\end{array}$ & $\begin{array}{c}\delta^{202} H \\
g \\
(\%) \\
\end{array}$ & $\begin{array}{c}\delta^{204} \mathrm{Hg} \\
(\% \text { o })\end{array}$ & $\begin{array}{c}\Delta{ }^{199} \mathbf{H} \\
\mathrm{g} \\
(\%) \\
\end{array}$ & $\begin{array}{c}\Delta^{201} H \\
g \\
(\% 0) \\
\end{array}$ \\
\hline \multirow{2}{*}{\multicolumn{2}{|c|}{$\begin{array}{l}\text { Intercomparison Hg Standard } \\
\text { (UM-Almaden) }\end{array}$}} & $\begin{array}{c}\text { Blum and } \\
\text { Bergquist, } 2007\end{array}$ & $22-25$ & $\begin{array}{l}-0.14 \\
\pm 0.06\end{array}$ & $\begin{array}{l}-0.27 \\
\pm 0.04\end{array}$ & $\begin{array}{l}-0.44 \\
\pm 0.07\end{array}$ & $\begin{array}{l}-0.54 \\
\pm 0.08\end{array}$ & $\begin{array}{l}-0.83 \\
\pm 0.11\end{array}$ & $\begin{array}{l}-0.01 \\
\pm 0.02\end{array}$ & $\begin{array}{l}-0.04 \\
\pm 0.04\end{array}$ \\
\hline & & Measured & 28 & $\begin{array}{l}-0.13 \\
\pm 0.13\end{array}$ & $\begin{array}{l}-0.26 \\
\pm 0.15\end{array}$ & $\begin{array}{l}-0.42 \\
\pm 0.17\end{array}$ & $\begin{array}{l}-0.52 \\
\pm 0.20\end{array}$ & $\begin{array}{l}-0.78 \\
\pm 0.29\end{array}$ & $\begin{array}{c}0.00 \\
\pm 0.12\end{array}$ & $\begin{array}{l}-0.03 \\
\pm 0.09\end{array}$ \\
\hline \multirow{2}{*}{$\begin{array}{l}\text { SRM } 1947 \text { Lake } \\
\text { Michigan Fish } \\
\text { Tissue }\end{array}$} & \multirow{2}{*}{$254 \pm 5$} & Point et al. 2011 & 9 & $\begin{array}{c}5.23 \\
\pm 0.29 \\
\end{array}$ & $\begin{array}{c}0.60 \\
\pm 0.19 \\
\end{array}$ & $\begin{array}{c}4.65 \\
\pm 0.44 \\
\end{array}$ & $\begin{array}{r}0.99 \\
\pm 0.28 \\
\end{array}$ & N/A & $\begin{array}{c}4.97 \\
\pm 0.25 \\
\end{array}$ & $\begin{array}{r}3.89 \\
\pm 0.29 \\
\end{array}$ \\
\hline & & Measured & 11 & $\begin{array}{c}5.61 \\
\pm 0.15\end{array}$ & $\begin{array}{c}0.73 \\
\pm 0.13\end{array}$ & $\begin{array}{c}5.05 \\
\pm 0.19\end{array}$ & $\begin{array}{c}1.22 \\
\pm 0.21\end{array}$ & $\begin{array}{c}1.73 \\
\pm 0.38\end{array}$ & $\begin{array}{c}5.30 \\
\pm 0.13\end{array}$ & $\begin{array}{c}4.13 \\
\pm 0.08\end{array}$ \\
\hline \multirow{7}{*}{$\begin{array}{l}\text { QC-04ERM01Murre } \\
\text { Egg Control } \\
\text { Material }\end{array}$} & \multirow{2}{*}{$101 \pm 3$} & Point et al. 2011 & 7 & $\begin{array}{c}1.50 \\
\pm 0.17 \\
\end{array}$ & $\begin{array}{c}0.55 \\
\pm 0.24 \\
\end{array}$ & $\begin{array}{c}1.78 \\
\pm 0.18 \\
\end{array}$ & $\begin{array}{c}0.97 \\
\pm 0.26 \\
\end{array}$ & N/A & $\begin{array}{c}1.25 \\
\pm 0.11 \\
\end{array}$ & $\begin{array}{c}1.05 \\
\pm 0.10\end{array}$ \\
\hline & & Measured & 13 & $\begin{array}{c}1.59 \\
\pm 0.12 \\
\end{array}$ & $\begin{array}{c}0.60 \\
\pm 0.14 \\
\end{array}$ & $\begin{array}{c}1.92 \\
\pm 0.16 \\
\end{array}$ & $\begin{array}{c}1.09 \\
\pm 0.24 \\
\end{array}$ & $\begin{array}{c}1.52 \\
\pm 0.44 \\
\end{array}$ & $\begin{array}{c}1.31 \\
\pm 0.11 \\
\end{array}$ & $\begin{array}{c}1.10 \\
\pm 0.10 \\
\end{array}$ \\
\hline & \multirow{5}{*}{$\begin{array}{c}\mathrm{ng} / \mathrm{g} \text { each } \\
\text { analytical } \\
\text { batch was run }\end{array}$} & 0.25 & 2 & $\begin{array}{c}1.57 \\
\pm 0.03\end{array}$ & $\begin{array}{c}0.63 \\
\pm 0.07 \\
\end{array}$ & $\begin{array}{c}1.94 \\
\pm 0.20 \\
\end{array}$ & $\begin{array}{c}1.25 \\
\pm 0.15 \\
\end{array}$ & $\begin{array}{c}1.73 \\
\pm 0.63 \\
\end{array}$ & $\begin{array}{c}1.25 \\
\pm 0.07\end{array}$ & $\begin{array}{c}1.00 \\
\pm 0.08 \\
\end{array}$ \\
\hline & & 0.5 & 1 & 1.54 & 0.60 & 2.01 & 1.17 & 1.72 & 1.25 & 1.13 \\
\hline & & 1.0 & 6 & $\begin{array}{c}1.57 \\
\pm 0.13\end{array}$ & $\begin{array}{c}0.55 \\
\pm 0.13 \\
\end{array}$ & $\begin{array}{c}1.86 \\
\pm 0.12 \\
\end{array}$ & $\begin{array}{r}.99 \\
\pm 0.15 \\
\end{array}$ & $\begin{array}{c}1.35 \\
\pm 0.35\end{array}$ & $\begin{array}{c}1.31 \\
\pm 0.10\end{array}$ & $\begin{array}{c}1.11 \\
\pm 0.04\end{array}$ \\
\hline & & 1.25 & 2 & $\begin{array}{c}1.64 \\
\pm 0.01 \\
\end{array}$ & $\begin{array}{c}0.69 \\
\pm 0.01 \\
\end{array}$ & $\begin{array}{c}2.03 \\
\pm 0.02 \\
\end{array}$ & $\begin{array}{c}1.20 \\
\pm 0.01 \\
\end{array}$ & $\begin{array}{c}1.66 \\
\pm 0.09 \\
\end{array}$ & $\begin{array}{c}1.34 \\
\pm 0.01 \\
\end{array}$ & $\begin{array}{c}1.12 \\
\pm 0.01 \\
\end{array}$ \\
\hline & & 1.5 & 2 & $\begin{array}{c}1.64 \\
\pm 0.10\end{array}$ & $\begin{array}{c}0.62 \\
\pm 0.04\end{array}$ & $\begin{array}{c}1.95 \\
\pm 0.03\end{array}$ & $\begin{array}{c}1.09 \\
\pm 0.02\end{array}$ & $\begin{array}{c}1.53 \\
\pm 0.13\end{array}$ & $\begin{array}{c}1.36 \\
\pm 0.11\end{array}$ & $\begin{array}{c}1.13 \\
\pm 0.04\end{array}$ \\
\hline
\end{tabular}




\section{Carbon and Nitrogen Stable Isotopes}

Aliquots of the samples (Appendix 2) were sent to the SIHERL facility in $\mathrm{LN}_{2}$ dry shippers for stable carbon and nitrogen isotope analyses using methods previously described by Hobson et al. (2002). After the samples were freeze-dried, lipids were extracted using a 2:1 chlorofom:methanol soak and rinse. Resulting filtrates were dried under a fume hood for $24 \mathrm{~h}$ before powdering and subsampling them for analysis. Carbon and nitrogen stable isotope ratios were obtained by loading about $1 \mathrm{mg}$ portions of the powdered samples into tin cups and combusting them at $1200^{\circ} \mathrm{C}$ using continuous-flow isotope ratio mass spectrometry (CFIRMS) on a Europa 20:20 IRMS interfaced with a Robo Prep combustion system. The ratios were expressed in delta $(\delta)$ notation relative to the Vienna Pee Dee Belemnite (VPDB) or AIR standards for carbon and nitrogen, respectively (Hobson et al. 1994). Analytical uncertainties were estimated at $\pm 0.3 \%$ for $\delta^{15} \mathrm{~N}$ and $\pm 0.1 \%$ for $\delta^{13} \mathrm{C}$ using within-run replicate measurements on albumen standards. The albumen standard, manufactured in-house at the SIHERL facility, has been calibrated to International Atomic Energy Agency (IAEA) Vienna PDB and Atmospheric Air standards for $\delta^{13} \mathrm{C}$ for $\delta^{15} \mathrm{~N}$, respectively.

\section{Statistics}

We used commercially available software to run statistical tests (SAS, JMP 9, Cary, NC, USA). One-way ANOVAs were used to identify differences among Hg levels and $\delta$ (MDF), $\Delta$ (MIF), $\delta^{15} \mathrm{~N}$, and $\delta^{13} \mathrm{C}$ values, and pair-wise comparisons were made using Tukey-Kramer tests at the $P$ $<0.05$ significance level.

\section{$\underline{\text { Persistent Organic Pollutants (POPs) }}$}

\section{Sample Preparation}

We selected 60 murre eggs and 58 clutches of gull eggs from the 19 sampling locations (Fig. 1 and Appendix 2) and analyzed them for chlorinated pesticides, PCBs, and BFRs (PBDEs). In each case, we weighed $3.0 \mathrm{~g}$ aliquots of the homogenized egg samples on a three-place analytical balance (Mettler XP1203S, Toledo OH, USA) and mixed them with about $8 \mathrm{~g}$ of diatomaceous earth that had been heated to $650{ }^{\circ} \mathrm{C}$ for 12 hours and cooled in a desiccator. The mixtures were transferred to $33 \mathrm{~mL}$ pressurized fluid extraction cells (PFE; ASE Dionex, Salt Lake City UT, USA) and $0.5 \mathrm{~mL}$ of mixed internal standard solution was added to them using gas-tight syringes weighed to five places on an analytical balance (Sartorius MC210S, Elk Grove IL, USA) before and after the liquids was injected into the cells. The internal standard solution contained ${ }^{13} \mathrm{C}$ labeled PCB congeners 28, 52, 118, 153, 180, 194, and 206; ${ }^{13} \mathrm{C}$ labeled 4,4-DDE, 4,4'-DDD, 4,4'-DDT, HCB, oxychlordane, trans-chlordane, trans-nonachlor; F labeled BDE congeners 47 and 160; and BDE 104. Between 20 and $89 \mathrm{ng}$ of the internal standard compounds were added to the samples, as appropriate. We prepared blanks and murre egg homogenates for quality assurance using the same techniques (Vander Pol et al. 2007), and we also analyzed two gull eggs twice to help verify analytical methods (Numbers 1340 and 1403; see Appendix 2). 
Next, we weighed $1.0 \mathrm{~mL}$ aliquots of six calibration solutions (A-F) in gas-tight syringes and added them to $11.0 \mathrm{~mL}$ PFE cells packed with clean heat-treated diatomaceous earth. The calibration solutions were covered by small amounts of diatomaceous earth before $0.25 \mathrm{~mL}$ aliquots of 24 toxaphene congener calibration solutions (A-F) were added to the cells (see above and Vander Pol 2005). Small quantities of diatomaceous earth were also used to cover the solutions before the internal standards were added to the cells, and then they were filled with more diatomaceous earth. The calibration solutions contained SRMs 2257 (Brominated Diphenyl Ethers in Isooctane), 2259 (Chlorinated Biphenyl Congeners in Isooctane), 2261 (Chlorinated Pesticides in Hexane), and 2275 (Chlorinated Pesticide Solution-II in Isooctane), and solutions of HBCDs, octachlorostyrene, and pentachlorobenzene.

Because the new SRMs 2257 and 2259 contained varying levels of congeners that were typically larger than the amounts found in previously used SRMs, we created three stock solutions for (1) pentachlorobenzene, (2) SRM 2259, and (3) SRMs 2261, 2275, 2257, HBCD, and octachlorostyrene to bracket the sample levels. The highest levels of these stocks (labeled 1) were gravimetrically combined to create Cal A. Middle level stocks (labeled 2) were combined for $\mathrm{Cal} \mathrm{B}$, and the lowest level stocks (labeled 3) were combined for Cal C. A small amount of Cal A was diluted to make Cal D. Cal B was diluted to make Cal E, and Cal C was diluted to make Cal F. The masses of the compounds in the calibration curves ranged from $0.002 \mathrm{ng} \mathrm{g}^{-1}$ to $555 \mathrm{ng} \mathrm{g}^{-1}$.

The samples, calibration solutions, and control materials were extracted with $\mathrm{CH}_{2} \mathrm{Cl}_{2}$ using the PFE. Conditions were as follows: cell temperatures $100{ }^{\circ} \mathrm{C}$, equilibration times 5 min, static times $5 \mathrm{~min}$, and cell pressures $13.8 \mathrm{MPa}$. Three cycles were run using one-third of the solvent each time. The PFE tubing was rinsed with $8.0 \mathrm{~mL}$ of $\mathrm{CH}_{2} \mathrm{Cl}_{2}$ between every sample by selecting the "rinse" option and instructing the instrument to alternate between the solvent $\mathrm{A}$ and $\mathrm{B}$ channels (both vessels contained $\mathrm{CH}_{2} \mathrm{Cl}_{2}$ ).

We reduced the sample extracts to about $10 \mathrm{~mL}$ using a Turbovap II (Zymark, Hopkinton, MA, USA) and evaporating them in a stream of purified $\mathrm{N}_{2}$. Then we ran nonvolatile solvent extractable material ("lipid") analyses on the extracts and reference materials by gravimetrically weighing $2.0 \mathrm{~mL}$ portions of the extracts and putting them into preweighed aluminum dishes and allowing the solvents to evaporate before reweighing the dishes. After analyzing the sample extracts for lipids, we reduced them to $1.0 \mathrm{~mL}$ in the Turbovap. High molecular mass compounds were removed from the extracts using size exclusion chromatography (SEC; Accuprep, J2 Scientific, Columbia, MO, USA) consisting of a PLGel $110 \mathrm{~mm}$ x $25 \mathrm{~mm}$ i.d; $10 \mu \mathrm{m}$ particle size guard column (Polymer Labs, Amherst, MA, USA) coupled to a $600 \mathrm{~mm}$ x $25 \mathrm{~mm}(10 \mu \mathrm{m}$ particle size with $100 \AA$ diameter pores) PLGel column (Polymer Labs, Amherst, MA, USA). A $\mathrm{CH}_{2} \mathrm{Cl}_{2}$ solvent was delivered at $10.0 \mathrm{~mL} / \mathrm{min}$. Absorbance was monitored at $254 \mathrm{~nm}$ using the internal UV/VIS detector (Linear, model 200, San Jose, CA, USA). Samples were automatically injected and the first $180.1 \mathrm{~mL}$ of $\mathrm{CH}_{2} \mathrm{Cl}_{2}$ containing high molecular mass material was discarded. The next $73.4 \mathrm{~mL}$, containing the analytes of interest, was collected and retained. After transferring the fractions to Turbovap tubes, we begin reducing their volume and changed the solvent to hexane, and then continued reducing them down to $0.5 \mathrm{~mL}$ before transferring them to amber $\mathrm{GC}$ autosampler vials. 
We cleaned the sample extracts with an automated solid phase extraction (SPE) Rapid Trace (Caliper Technologies, Hopkinton, MA, USA) using $3.0 \mathrm{~mL}$ SPE cartridges. Alumina (50 $\mu \mathrm{m}$ to $200 \mu \mathrm{m}$; Arcōs Organics, Trenton, NJ, USA) was activated by baking it at $650{ }^{\circ} \mathrm{C}$ overnight and allowing it to cool in a desiccator. The alumina was partially deactivated by adding $5 \%$ hexanerinsed, deionized water (mass fraction) to it. Resulting substrates were packed between two frits in a $3.0 \mathrm{~mL}$ Bond Elut reservoir (Varian, Palo Alto, CA, USA) to about $3.9 \mathrm{~cm}$ bed height. This gave us a mass of about $1.8 \mathrm{~g}$ alumina. Sample extracts were passed through the alumina columns and eluted with $9.0 \mathrm{~mL}$ of $35: 65 \mathrm{CH}_{2} \mathrm{Cl}_{2}$ :hexane (volume fraction) at $1.0 \mathrm{~mL} / \mathrm{min}$. The

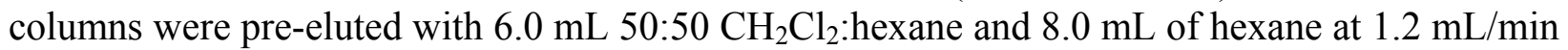
before adding the samples. The Rapid Trace performed clean up steps using $\mathrm{CH}_{2} \mathrm{Cl}_{2}$ and hexane between each sample run. After transferring the fractions to Turbovap tubes, we began reducing their volume and changed the solvent to hexane, and then continued reducing them down to 0.5 $\mathrm{mL}$ before transferring them to amber GC autosampler vials.

\section{GC/MS Analyses}

We analyzed the samples with an electron impact (EI) GC/MS (Agilent, Palo Alto, CA, USA) operating in the selected ion monitoring mode (SIM) for selected chlorinated pesticides and all of the PCB and PBDE congeners. The instrument was equipped with a $30.0 \mathrm{~m} \mathrm{x} 0.18 \mathrm{~mm} \times 0.18$ $\mu \mathrm{m}$ i.d. DB-5MS column (J\&W Scientific, Folsom, CA, USA) with a $5.0 \mathrm{~m} \times 0.25 \mathrm{~mm}$ retention gap added to the beginning of the column. A PTV injector (Agilent 6850) injected the samples in $20.0 \mu \mathrm{L}(4 \times 5 \mu \mathrm{L})$ amounts after the solvent vent flow rate set at $65.0 \mathrm{~mL} / \mathrm{min}$ of nitrogen and the unit's inlet was cooled to $10^{\circ} \mathrm{C}$ for $1.5 \mathrm{~min}$ with liquid nitrogen. After injection, the inlet was heated to a final transfer temperature of $250{ }^{\circ} \mathrm{C}$ at a rate of $720^{\circ} \mathrm{C} / \mathrm{min}$ with no hold time, and then the temperature was ramped up to $280{ }^{\circ} \mathrm{C}$ at a rate of $20^{\circ} \mathrm{C} / \mathrm{min}$ and held for $10 \mathrm{~min}$ to bake off any remaining compounds from the liner.

The $\mathrm{GC}$ oven was held at $80{ }^{\circ} \mathrm{C}$ for $1.5 \mathrm{~min}$ and then the temperature was ramped up to $170{ }^{\circ} \mathrm{C}$ at a rate of $25{ }^{\circ} \mathrm{C} / \mathrm{min}$, then ramped up to $270{ }^{\circ} \mathrm{C}$ at a rate of $2{ }^{\circ} \mathrm{C} / \mathrm{min}$, and then ramped up one more time to $325^{\circ} \mathrm{C}$ at a rate of $25^{\circ} \mathrm{C} / \mathrm{min}$ before it was held isothermally for $10 \mathrm{~min}$ (total run time $67.3 \mathrm{~min}$ ). We used helium as the carrier gas set at a constant flow rate at $0.7 \mathrm{~mL} / \mathrm{min}$, and maintained the quadrupole, source, and transfer line at $150^{\circ} \mathrm{C}, 250{ }^{\circ} \mathrm{C}$, and $300{ }^{\circ} \mathrm{C}$, respectively.

We set the GC/MS in the negative chemical ionization (NCI) mode using SIM equipped with a $30.0 \mathrm{~m} \times 0.18 \mathrm{~mm} \times 0.18 \mu \mathrm{m}$ i.d. DB-XLB column (J\&W Scientific, Folsom, CA, USA) that had a $5.0 \mathrm{~m} \times 0.25 \mathrm{~mm}$ retention gap fitted to one end. Methane was used as the reaction gas and samples were injected using a PTV, as described above. The GC oven was held at $120{ }^{\circ} \mathrm{C}$ for 1 min, then ramped up to $230{ }^{\circ} \mathrm{C}$ at a rate of $30{ }^{\circ} \mathrm{C} / \mathrm{min}$, then ramped up to $260{ }^{\circ} \mathrm{C}$ at a rate of 10 ${ }^{\circ} \mathrm{C} / \mathrm{min}$, then ramped to $284{ }^{\circ} \mathrm{C}$ at a rate of $4.8^{\circ} \mathrm{C} / \mathrm{min}$, and then ramped up one more time to 300 ${ }^{\circ} \mathrm{C}$ at a rate of $9.6^{\circ} \mathrm{C} / \mathrm{min}$ before it was held isothermally for $1.67 \mathrm{~min}$ (total run time $16.0 \mathrm{~min}$ ). The carrier gas was helium set at a flow rate of $1.5 \mathrm{~mL} / \mathrm{min}$ for $4.5 \mathrm{~min}$. Gas flow was then ramped up to $0.7 \mathrm{~mL} / \mathrm{min}$ at a rate of $50.0 \mathrm{~mL} / \mathrm{min}$ for $8.5 \mathrm{~min}$, and then ramped up to 1.4 $\mathrm{mL} / \mathrm{min}$ at a rate of $50.0 \mathrm{~mL} / \mathrm{min}$ for $3.0 \mathrm{~min}$. All other conditions were the same as the EI run. The 2008 and 2009 samples were analyzed separately in four batches. Glaucous gull samples were analyzed alone, and the murres and glaucous-winged gull eggs were analyzed together. 


\section{Statistics}

We quantified the data using at least 3 calibration points that bracketed the samples and allowed the intercept to float. Limits of detection (LODs) were calculated as the lowest observable calibration solutions divided by the sample masses, and limits of quantitation (LOQs) were calculated as the average blank values plus 3 times the standard deviations and then divided by the sample masses.

We ran a multivariate analyses of variance (MANOVA) on a lipid-mass basis on the compounds that had all values above detection limits and the control materials fell within the reference range (4,4'-DDE, $\beta$-HCH, cis-nonachlor, HCB, pentachlorobenzene, heptachlor epoxide, mirex, octachlorostyrene, oxychlordane, and the sum of 16 PCB congeners because of limited degrees of freedom-28+31, 105, 118, 119, 128, 137, 138, 146, 149, 153+132, 156, 170, 177, 180+193, 194, and 207) to compare the Norton Sound common murre and glaucous gull eggs with eggs from nesting locations outside of it. One exception was made; BDE 47 was included in the MANOVA even though one unidentified murre egg from Cape Lisburne I. was below the detection limit (Egg ID 1454 was $0.08732 \mathrm{ng} \mathrm{g}^{-1}$ vs its LOQ of $0.08734 \mathrm{ng} \mathrm{g}^{-1}$ ) We also ran MANOVAs on eggs from all of the colonies for further geographical comparisons, and on the St. Lawrence, St. George, and St. Lazaria island common and thick-billed murre samples to check for species differences. If MANOVAs differed statistically $(P<0.05)$, we used individual ANOVAs and Tukey-Kramer post-hoc tests to find out which colonies were different. We also conducted principal components analyses (PCAs) on total compound percentages to help visualize patterns, and ran regressions on the compounds shown in bold (see above) to check the multiyear St. George Island thick-billed murre and St. Lazaria Island common and thick-billed murre data sets for temporal changes. Correlations on a lipid-mass basis were conducted with the stable carbon and nitrogen isotopes. We used commercially available software to run all statistical tests (SAS, JMP 9, Cary, NC, USA).

\section{Results}

Mercury ( $\mathrm{Hg})$ and $\mathrm{Hg}$, Carbon (C), and Nitrogen (N) Isotopes

Because the $\mathrm{Hg}$ levels found in the murre and gull eggs were $>84 \%$ methylmercury (Davis et al. 2004), only total $\mathrm{Hg}$ values are reported here. $\mathrm{Hg}$ levels and $\delta^{15} \mathrm{~N}$ and $\delta^{13} \mathrm{C}$ isotope values are listed in Appendix 3.

\section{Taxonomic Groupings}

This data set contained 30 common murre, 25 thick-billed murre, 5 unidentified murre, 53 glaucous gull, and 5 glaucous-winged gull eggs. Glaucous and glaucous-winged gulls have similar foraging strategies and occupy similar ecological niches within their arctic (glaucous gulls) and subarctic-temperate ranges (glaucous-winged gulls; see Vander Pol et al. 2009). However, because these species do not nest together, we could not directly compare Hg levels in their eggs, and because glaucous-winged gull eggs were only obtained from a single colony 
(Aiktak Island in the Aleutians), we elected to refer to these birds collectively as "gulls". Common and thick-billed murres are also ecologically similar species, but they use different foraging strategies. Both species are deep-diving fish-eaters capable of exploiting marine environments up to $170 \mathrm{~km}$ from their colonies (Ainley et al. 2002). However, common murres tend to feed closer to shore and at shallower depths, compared to thick-billed murres, and thickbills typically take more benthic fish and invertebrates than commons (Swartz 1966, Springer et al. 1984, Springer et al. 1986, Springer et al. 1987, Dragoo 1991, Barrett et al. 1997, Gaston and Jones 1998, Roseneau et al. 2000, Vander Pol et al. 2004). These species typically nest close to one another at many Alaskan colonies, but almost all of the birds ( $90 \%)$ occupying the three Norton Sound nesting locations targeted in this study (i.e., Sledge Island, Bluff, and Cape Denbigh) were common murres (e.g., see Sowls et al. 1978, Murphy et al. 1985).

Given this information, we compared common and thick-billed eggs from two colonies where they nested together (St. Lawrence and St. Lazaria islands; see Fig. 1) to see how interchangeable these species might be as biointegrators of $\mathrm{Hg}$ in their local marine environments. Although total $\mathrm{Hg}$ levels did not differ significantly at St. Lazaria Island (ANOVA on $\log \mathrm{Hg}$ ), common murre values were higher than thick-billed murre levels at St. Lawrence Island $\left(P=0.05\right.$; see Fig. 4). However, isotope fractionation patterns for $\delta^{202} \mathrm{Hg}$ and $\Delta \Delta^{199} \mathrm{Hg}$, and $\delta{ }^{15} \mathrm{~N}$ and $\delta^{13} \mathrm{C}$ values did not differ at either colony $(P>0.218$; see Fig. 5). Although there was a significant difference in $\mathrm{Hg}$ levels between these species at St. Lawrence Island, the difference was small relative to the geographic trends seen across the study area (Figs. 4 and 6). This information indicated that either species could be used to represent regional $\mathrm{Hg}$ patterns. All of the $\mathrm{Hg}$ isotope and $\delta^{15} \mathrm{~N}$ and $\delta^{13} \mathrm{C}$ data were also similar between the species. Given this information, we elected to treat these birds as just "murres" at the colonies where they nested together.

\section{Taxonomic Comparisons of $\mathrm{Hg}$ Levels and $\delta^{15} \mathrm{~N}$ and $\delta^{13} \mathrm{C}$}

$\mathrm{Hg}$ levels ranged from $2 \mathrm{ng} \mathrm{g}^{-1}$ to $644 \mathrm{ng} \mathrm{g}^{-1}$, with a grand mean of $118 \mathrm{ng} \mathrm{g}^{-1}(\mathrm{n}=118)$ and an overall relative standard deviation (RSD) of $71 \%$. The average RSD among replicate eggs in each sampling event $(\mathrm{n}=5)$ was $39 \%$. Murres eggs varied between $2 \mathrm{ng} \mathrm{g}^{-1}$ and $262 \mathrm{ng} \mathrm{g}^{-1}$, with a mean and standard error of $83 \mathrm{ng} \mathrm{g}^{-1} \pm 9.8 \mathrm{ng} \mathrm{g}^{-1}$, and gull eggs ranged from $55 \mathrm{ng} \mathrm{g}^{-1}$ to $644 \mathrm{ng}$ $\mathrm{g}^{-1}$, with a mean and standard error of $154 \mathrm{ng} \mathrm{g}^{-1} \pm 10.0 \mathrm{ng} \mathrm{g}^{-1}$. Overall, $\mathrm{Hg}$ levels were significantly higher in the gull eggs than they were in the murres eggs (ANOVA, $P<0.0001$ ), and $\delta^{15} \mathrm{~N}$ was also significantly higher $(P=0.008)$ in these samples $(16.3 \% \pm 0.28 \%)$, compared to the murre eggs $(15.2 \% \pm 0.28 \%)$. In contrast, $\delta^{13} \mathrm{C}$ was significantly lower $(P=$ $0.0003)$ in the gull eggs $(-21.8 \% \pm 0.23 \%$ ) than it was in the murre eggs $(-20.6 \% \pm 0.23 \%)$. When we compared murre and gull eggs within regions, the results were the same as the overall comparisons $(P<0.05)$, with the following exceptions: in the northern Bering and Chukchi seas, there was no difference in $\delta^{15} \mathrm{~N}$ values; in Norton Sound, the murres had higher $\delta^{15} \mathrm{~N}$ levels than the gulls did $(P=0.002)$ and there was no difference in $\delta^{13} \mathrm{C}$ values; and in the southern Bering Sea, gull $\delta^{13} \mathrm{C}$ levels were higher than the murre values $(P=0.05)$. 


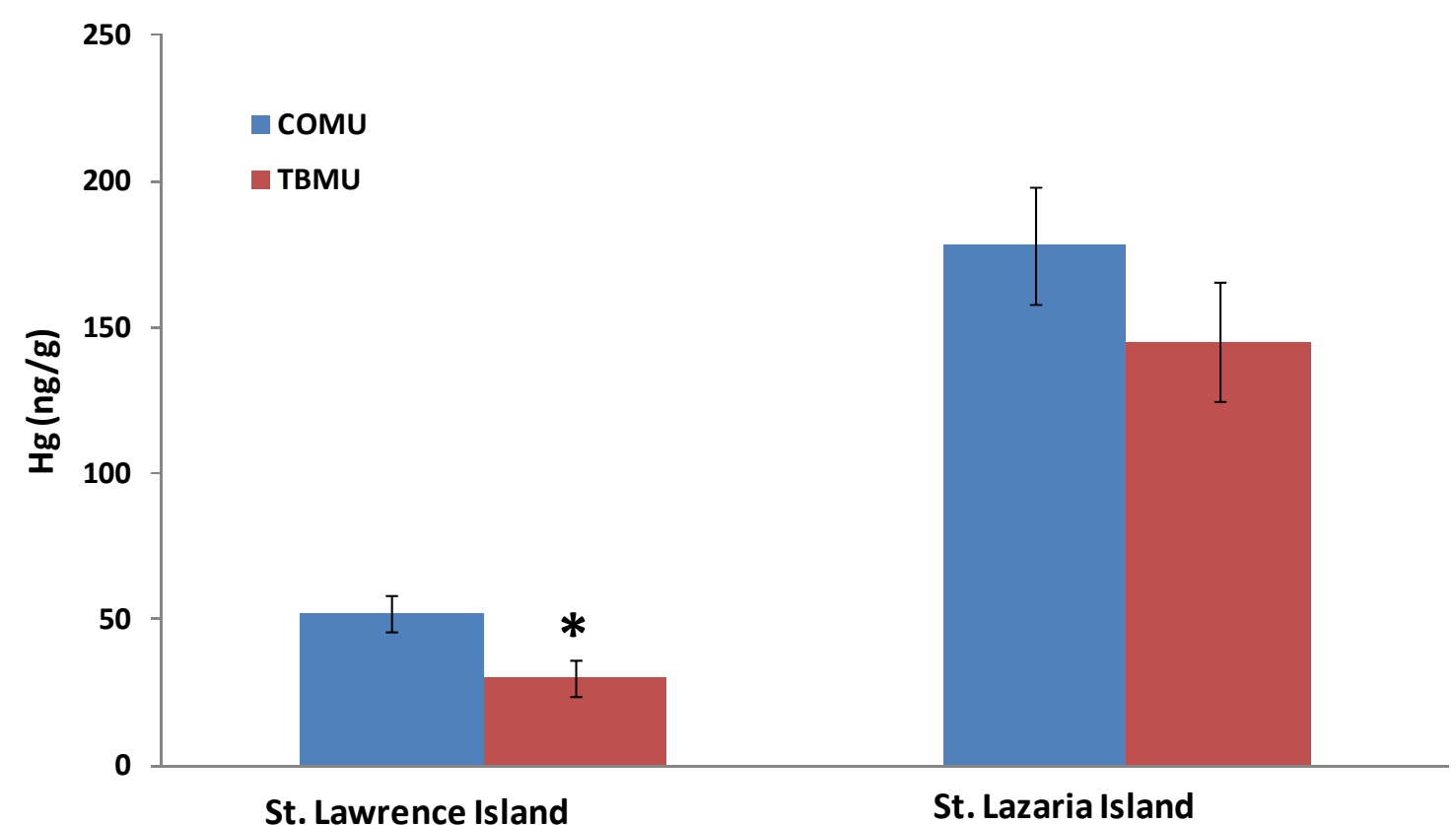

Figure 4. $\mathrm{Hg}$ levels in common murre and thick-billed murre eggs from St. Lawrence (northern Bering Sea) and St. Lazaria (southern Gulf of Alaska) islands. Species differences were only present at St. Lawrence Island $(P=0.05)$. Bars $=$ mean \pm standard error.

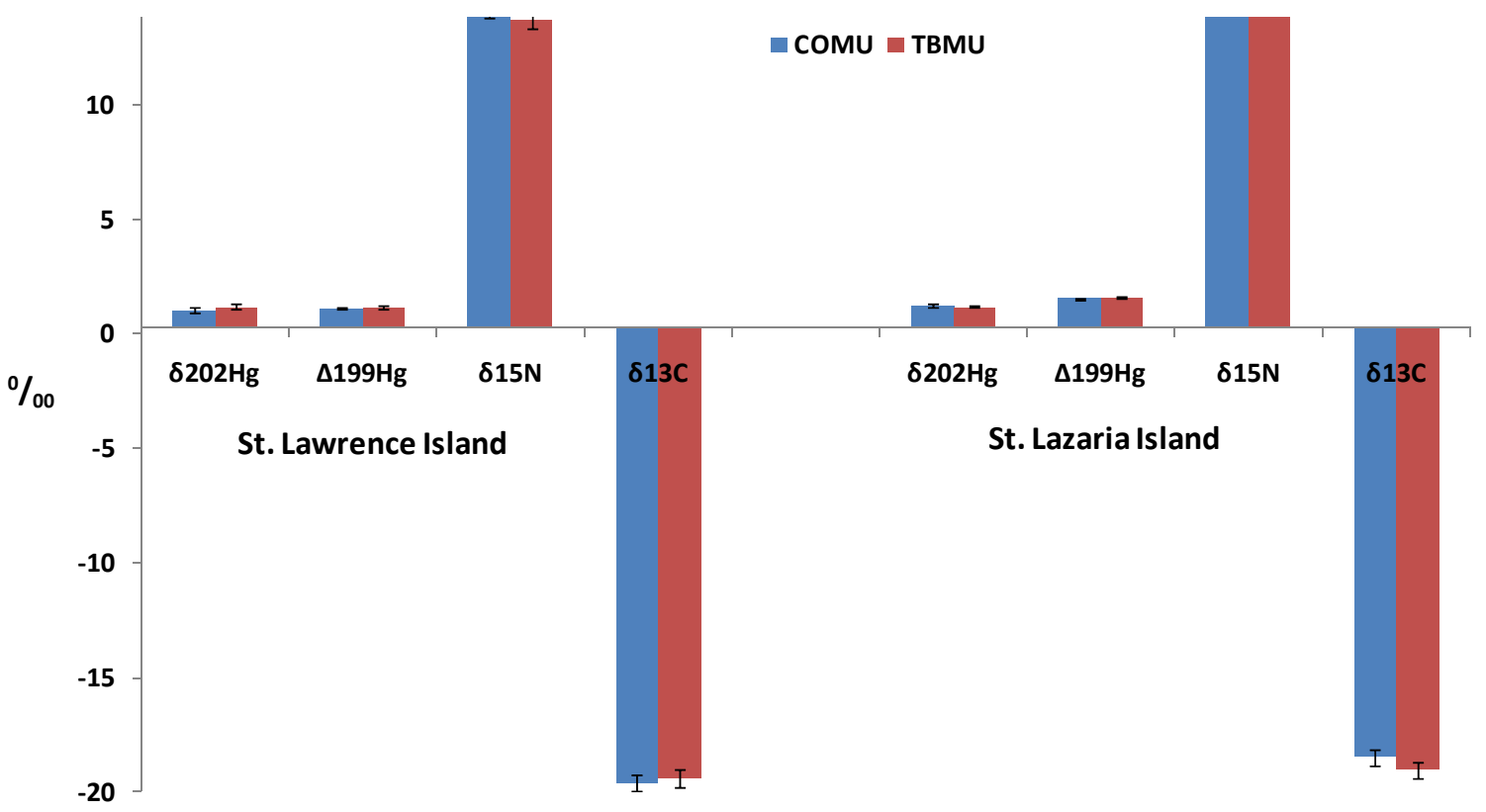

Figure 5. Hg isotope patterns in common murre and thick-billed murre eggs from St. Lawrence (northern Bering Sea) and St. Lazaria (southern Gulf of Alaska) islands. Species differences were not present at either colony. Bars $=$ mean \pm standard error. 


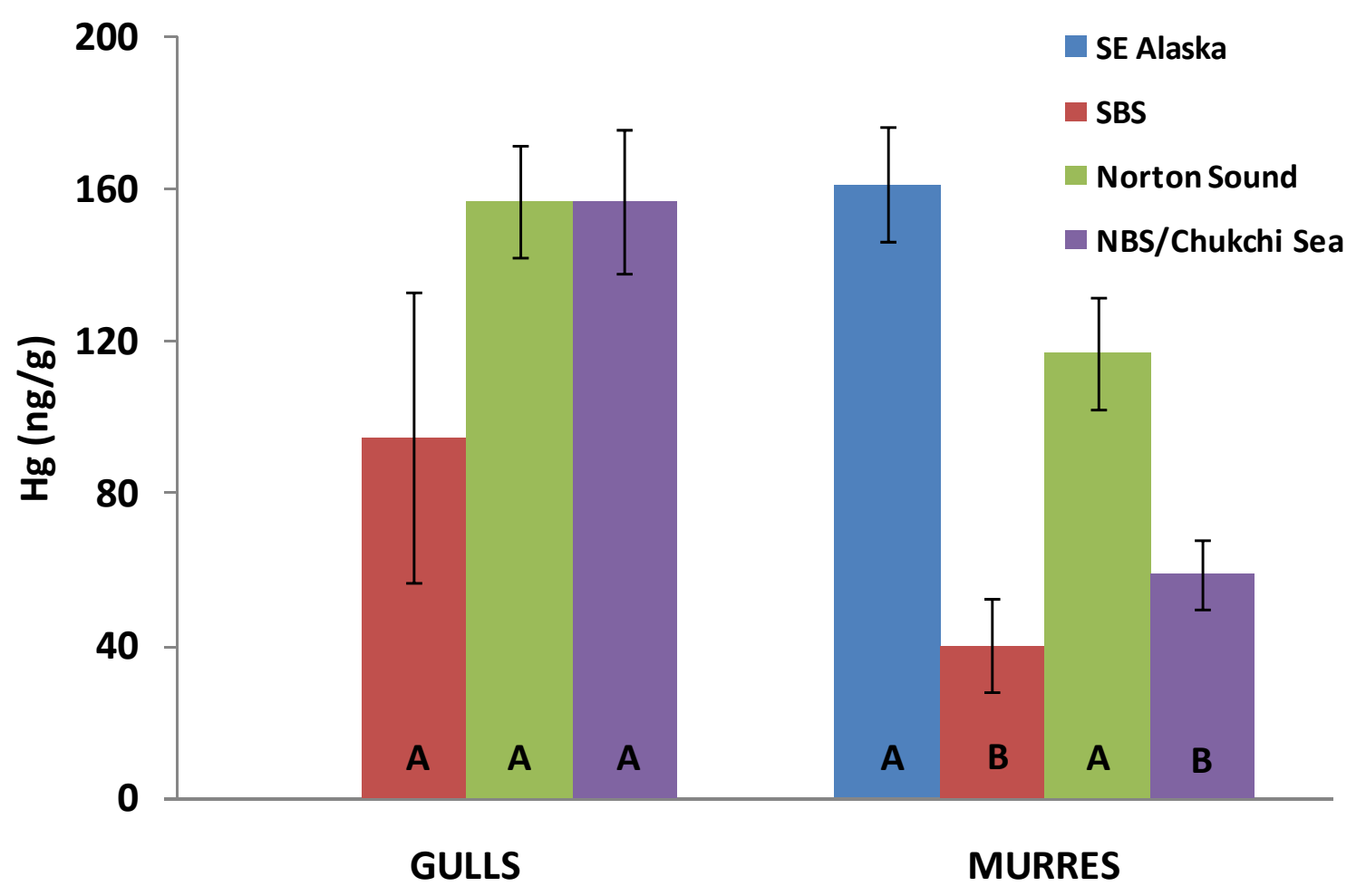

Figure 6. Hg levels in murre and gull eggs among regions. Bars $=$ mean \pm standard error, and different letters indicate significant differences based on 1-way ANOVA and Tukey tests. SE Alaska $=$ southeastern Alaska, $\mathrm{SBS}=$ southeastern Bering Sea, and NBS/Chukchi Sea $=$ northern Bering and Chukchi seas. 
We initially checked the entire data set for geographic patterns in Hg levels to identify largescale trends and lay the groundwork for $\mathrm{Hg}$ isotope analyses. To make the comparisons, we grouped the colonies into four regions: southeastern Alaska (SE Alaska); the southern Bering Sea (SBS); the northern Bering and Chukchi seas (NBS/Chukchi Sea); and Norton Sound. Significant regional variation was not detected in the gull eggs (1-way ANOVA, $P>0.05$ ), although $\mathrm{Hg}$ levels in the SBS were lower than in the NBS/Chukchi Sea and Norton Sound (Fig. 6). Also, $\delta^{15} \mathrm{~N}$ was significantly higher in the Norton Sound gull eggs, compared to the SBS and NBS/Chukchi Sea (Fig. 7). The SBS gull eggs had the highest $\delta^{13} \mathrm{C}$ levels and the NBS/Chukchi Sea eggs had the lowest, while eggs from Norton Sound contained intermediate amounts (Fig. 8). When we compared all of the gull eggs together, we found a significant negative correlation between $\mathrm{Hg}$ and $\delta^{13} \mathrm{C}(P=0.03)$, but did not find a correlation between $\mathrm{Hg}$ and $\delta^{15} \mathrm{~N}$. We also compared the individual colonies to check geographic variability in $\mathrm{Hg}, \delta^{15} \mathrm{~N}, \delta^{13} \mathrm{C}$ at a higher spatial resolution (Fig. 9). Murre eggs clearly had the most distinct geographic Hg pattern, with significantly higher levels in Norton Sound and SE Alaska than in the NBS/Chukchi Sea and SBS (1-way ANOVA, $P<0.05$; see Fig. 6 ). $\delta^{15} \mathrm{~N}$ was also higher in the Norton Sound murre eggs, compared to the other regions, while the SBS had the lowest levels, and SE Alaska and NBS/Chukchi Sea had intermediate values (Fig. 7). $\delta^{13} \mathrm{C}$ also varied geographically, with the lowest levels in Norton Sound and the SBS, intermediate values in the NBS/Chukchi Sea, and the highest levels in SE Alaska (Fig. 8). When we compared all of the murre eggs together, no correlation was present between $\mathrm{Hg}$ and $\delta^{13} \mathrm{C}$, but we did find a significant positive correlation between $\mathrm{Hg}$ and $\delta^{15} \mathrm{~N}(P=0.005)$. 


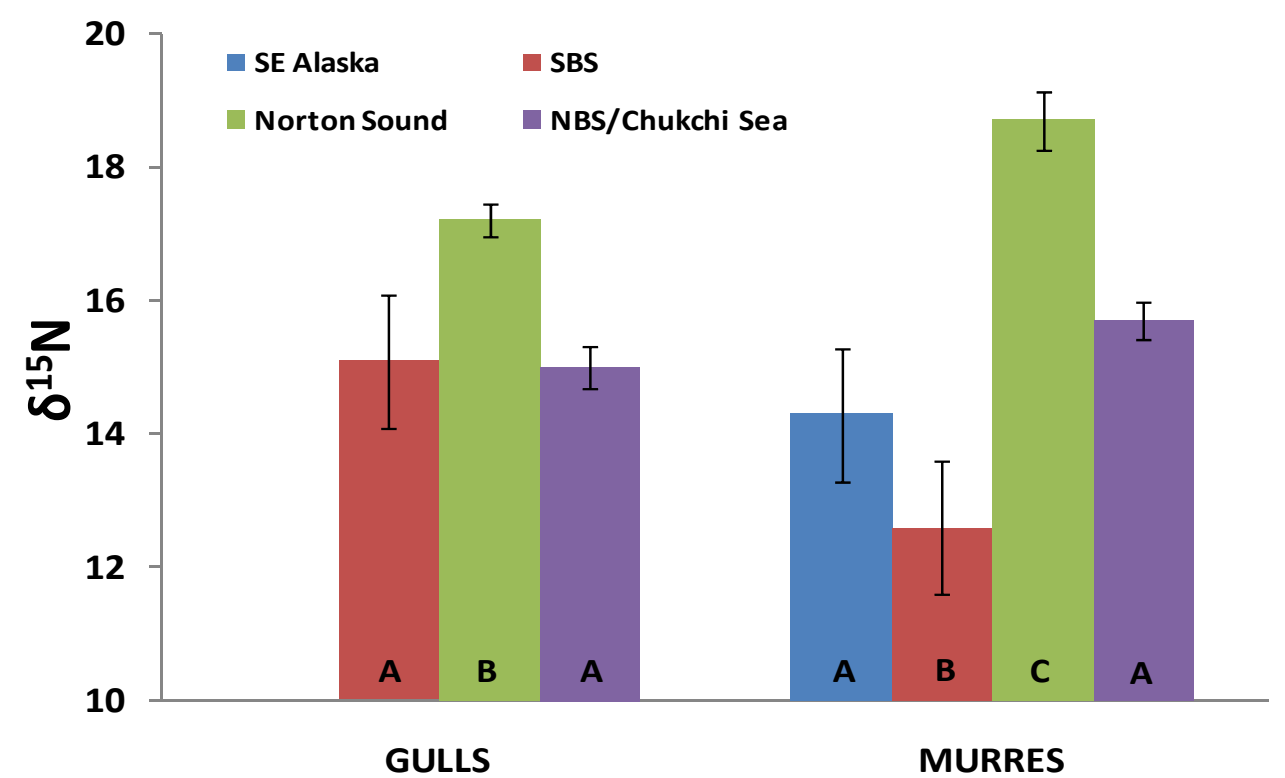

Figure 7. $\delta^{15} \mathrm{~N}$ in murre and gull eggs among regions. Bars $=$ mean \pm standard error, and different letters indicate significant differences based on 1-way ANOVA and Tukey tests. SE Alaska = southeastern Alaska, SBS = southeastern Bering Sea, and NBS/Chukchi Sea $=$ northern Bering and Chukchi seas.

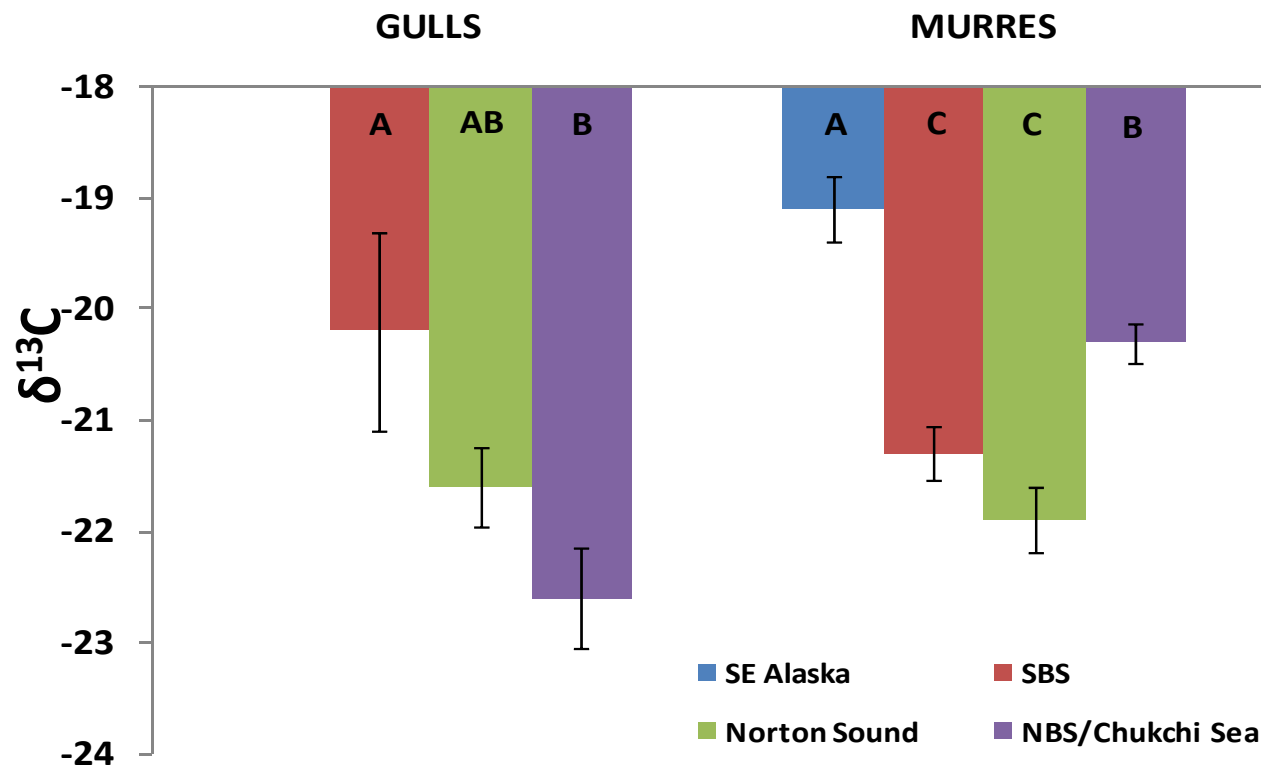

Figure $8 . \delta^{13} \mathrm{C}$ in murre and gull eggs among regions. Bars $=$ mean \pm standard error, and different letters indicate significant differences based on 1-way ANOVA and Tukey tests. SE Alaska = southeastern Alaska, SBS = southeastern Bering Sea, and NBS/Chukchi Sea $=$ northern Bering and Chukchi seas. 

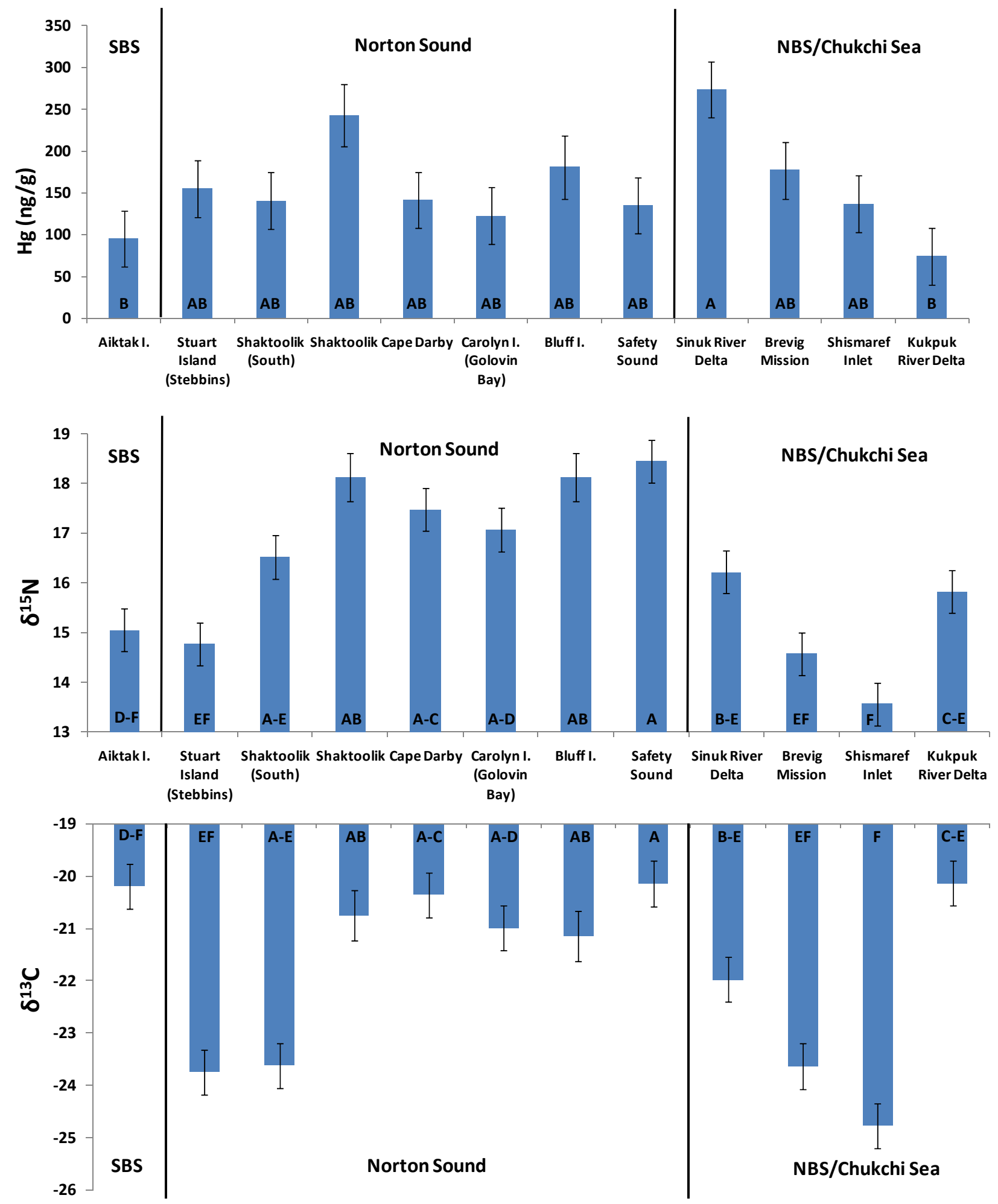

Figure 9. $\mathrm{Hg}, \delta^{15} \mathrm{~N}$, and $\delta^{13} \mathrm{C}$ in gull eggs compared among colonies. Colonies are grouped by region, starting in the southern Bering Sea (SBS) and progressing northward into Norton Sound and the northern Bering and Chukchi seas (NBS/Chukchi Sea). Bars $=$ mean \pm standard error, and different letters indicate significant differences based on 1-way ANOVA and Tukey tests. 


\section{Hg Isotopes}

The Hg levels that we found in the gull eggs suggested that these seabirds did not have any spatially explicit patterns like the murres did. In particular, the gulls in Norton Sound where this study was focused did not display consistently different $\mathrm{Hg}$ levels, compared to the northern Bering and Chukchi sea colonies (Fig. 9). This indicates they are not good biointegrators of sources and cycling of $\mathrm{Hg}$. This outcome was not surprising, because gulls are highly migratory and have diverse, opportunistic foraging behaviors that include feeding on surface fish, intertidal invertebrates, eggs and small chicks, berries and seaweed, and scavenging on terrestrial and marine carrion and human refuse (Roseneau et al. 2008, Vander Pol et al. 2009). These factors make interpreting contaminant patterns in their eggs much more difficult than it is for murres. Given our knowledge of gull biology and the varying amounts of $\mathrm{Hg}$ in their eggs, we decided to focus the $\mathrm{Hg}$ isotope analyses on murres, and exclude gulls from this part of the study. Results of the analytical work on the 25 common murre and 20 thick-billed murre eggs from the seven representative nesting locations, including the three Norton Sound colonies, are shown in Appendix 4. We grouped the data by colony to make it easier to identify geographic patterns in $\mathrm{Hg}$ isotopic fractionation and compare $\mathrm{Hg}$ levels and $\delta^{15} \mathrm{~N}$ and $\delta^{13} \mathrm{C}$ isotopes in the samples.

The quality control samples for the $\mathrm{Hg}$ isotope analyses agreed with previously published values (Table 5), validating our analytical methods. All of the murre eggs showed significant positive mass dependent fractionation (MDF) for all of the measured isotopes, and they also displayed significant positive mass independent fractionation (MIF) for all measured odd isotopes (Fig. 10). We plotted $\Delta^{199} \mathrm{Hg}$ and $\delta^{202} \mathrm{Hg}$ values against one another to help illustrate separation of isotopic patterns among colonies (Fig. 11), and we also summarized the data to statistically compare the colonies by calculating their means and checking them with 1-way ANOVA and Tukey tests. Hg levels, MIF, and MDF all displayed gradients running from deep within Norton Sound (i.e., at Cape Denbigh) westward toward the northern Bering Sea (Fig. 12). Hg levels were highest in Norton Sound and lowest in the northern Bering Sea, while $\Delta^{199} \mathrm{Hg}$ and $\delta^{202} \mathrm{Hg}$ were lowest in Norton Sound and highest in the northern Bering Sea. $\delta^{15} \mathrm{~N}$ and $\delta^{13} \mathrm{C}$ also displayed this gradient, with $\delta^{15} \mathrm{~N}$ highest in Norton Sound and $\delta^{13} \mathrm{C}$ lowest at its eastern end (i.e., at Cape Denbigh; see Fig. 13). We also analyzed samples from two of the more distant colonies, St. Lazaria Island in the Gulf of Alaska and St. George Island in the southeastern Bering Sea, for comparative purposes. These nesting locations had their own individual patterns of $\mathrm{Hg}, \delta^{202} \mathrm{Hg}, \Delta^{199} \mathrm{Hg}, \delta^{15} \mathrm{~N}$, and $\delta^{13} \mathrm{C}$ that differed from the Norton Sound and northern Bering Sea colonies (Figs. 12 and 13). We also found significant positive pair-wise correlations $(P<$ $0.05)$ between $\delta^{202} \mathrm{Hg}-\Delta^{199} \mathrm{Hg}, \mathrm{Hg}-\delta^{15} \mathrm{~N}, \delta^{13} \mathrm{C}-\delta^{202} \mathrm{Hg}$, and $\delta^{13} \mathrm{C}-\Delta^{199} \mathrm{Hg}$ at the Norton Sound and northern Bering Sea nesting locations. In contrast, significant negative pair-wise correlations were found between $\mathrm{Hg}-\delta^{202} \mathrm{Hg}, \mathrm{Hg}-\Delta^{199} \mathrm{Hg}, \delta^{15} \mathrm{~N}-\delta^{202} \mathrm{Hg}, \delta^{15} \mathrm{~N}-\Delta^{199} \mathrm{Hg}, \delta^{13} \mathrm{C}-\mathrm{Hg}$, and $\delta^{13} \mathrm{C}-$ $\delta^{15} \mathrm{~N}$. Some researchers have used the slope of linear regressions between $\Delta^{199} \mathrm{Hg}$ and $\Delta^{199} \mathrm{Hg}$ to infer the chemical species of $\mathrm{Hg}$ undergoing photoreduction (Bergquist and Blum 2007, Point et al. 2011). The overall slope in this study was 1.08 (Fig. 14), which is closer to the experimentally derived value for inorganic $\mathrm{Hg}$ photoreduction (1.0) than for $\mathrm{MeHg}$ photoreduction (1.3). 


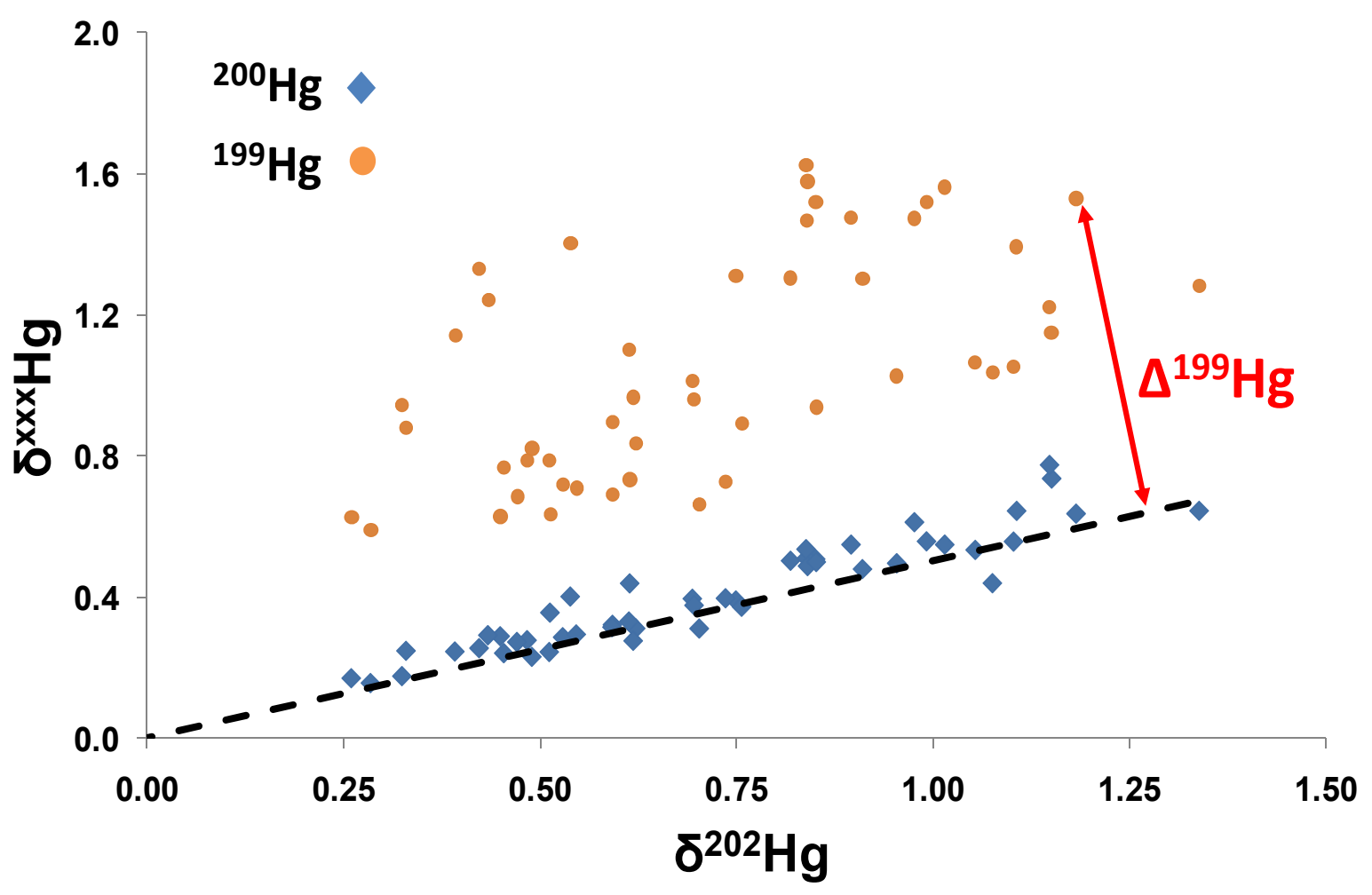

Figure $10 . \delta^{200} \mathrm{Hg}$ and $\delta^{199} \mathrm{Hg}$ vs. $\delta^{202} \mathrm{Hg}$ for all murre and gull eggs showing measured values relative to theoretical values based on mass dependent kinetic isotope fractionation. The measured values for $\delta^{200} \mathrm{Hg} v s \delta^{202} \mathrm{Hg}$ were in agreement with the theoretical values, indicating all of the fractionation was mass dependent fractionation (MDF), as suggested by the models. However, $\delta^{199} \mathrm{Hg}$ deviated significantly from the theoretical MDF line, indicating that mass independent fractionation (MIF, denoted by $\Delta{ }^{199} \mathrm{Hg}$ ) was present in the eggs for odd isotopes. 


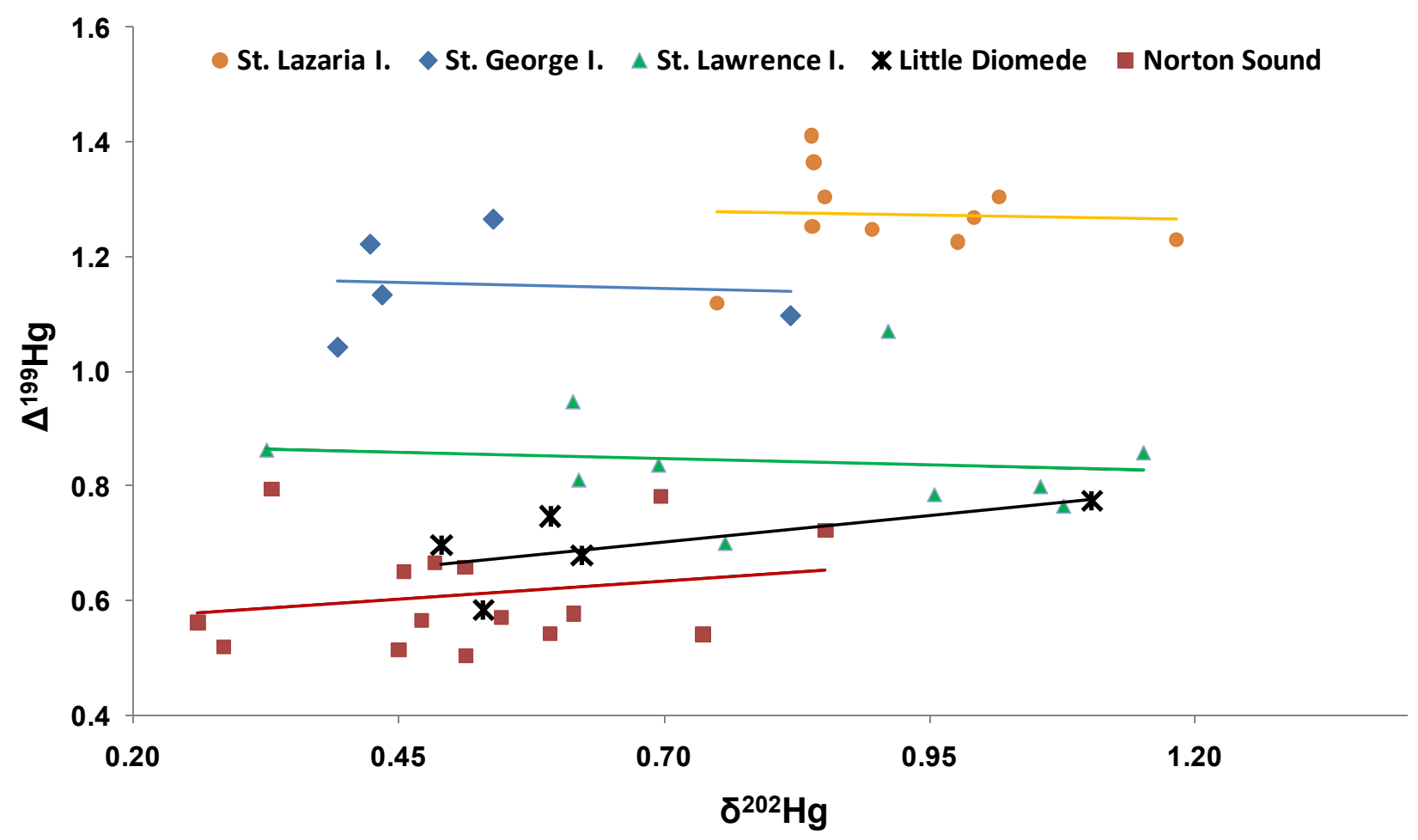

Figure 11. A three $\mathrm{Hg}$ isotope diagram showing colony separations by their $\Delta^{199} \mathrm{Hg} v s \delta^{202} \mathrm{Hg}$ signatures. 

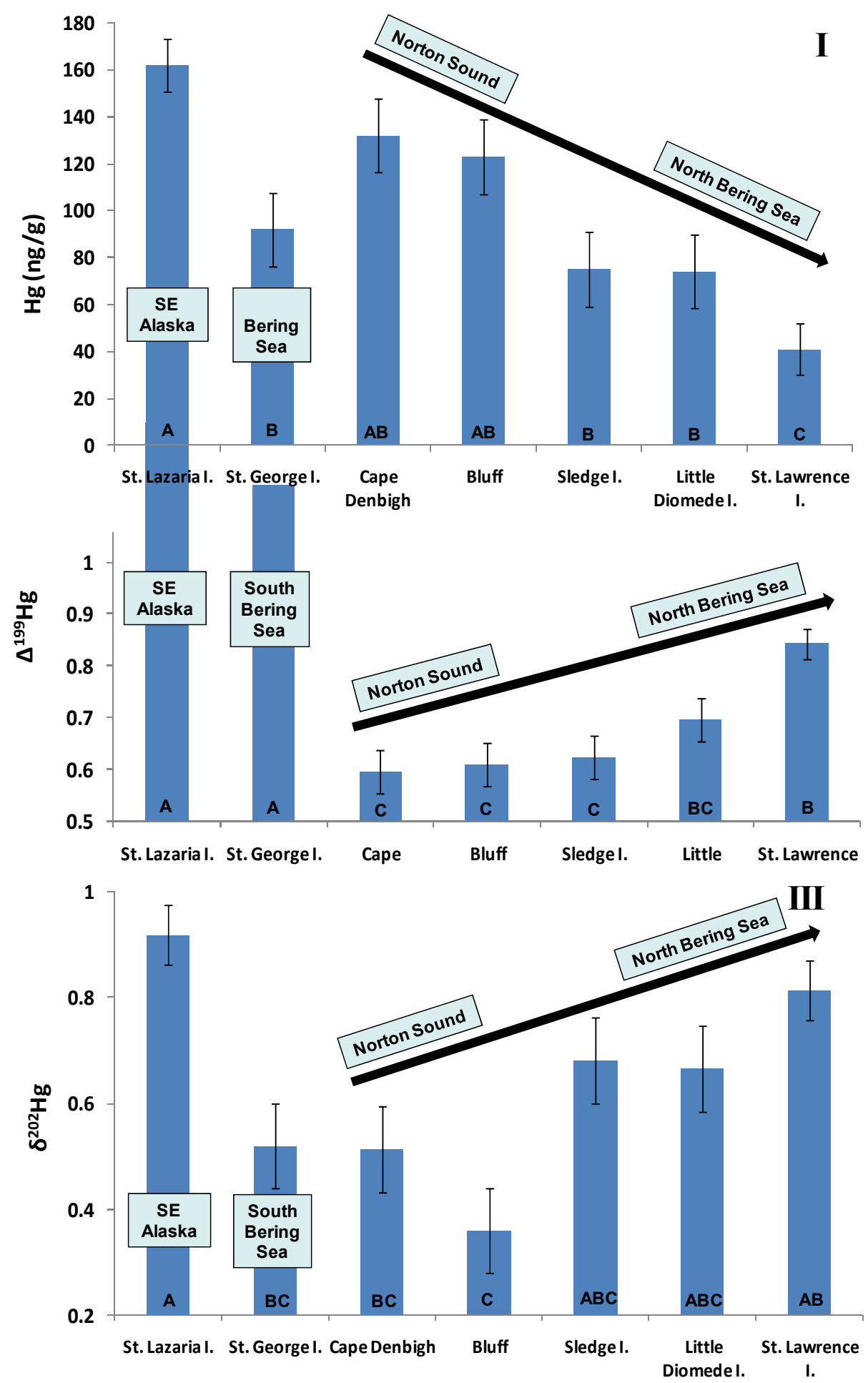

Figure 12. Hg (I), MIF (II), and MDF (III) gradients between the Norton Sound and northern Bering Sea regions. Bars $=$ mean \pm standard error, and different letters indicate significant differences based on 1way ANOVA and Tukey tests. 

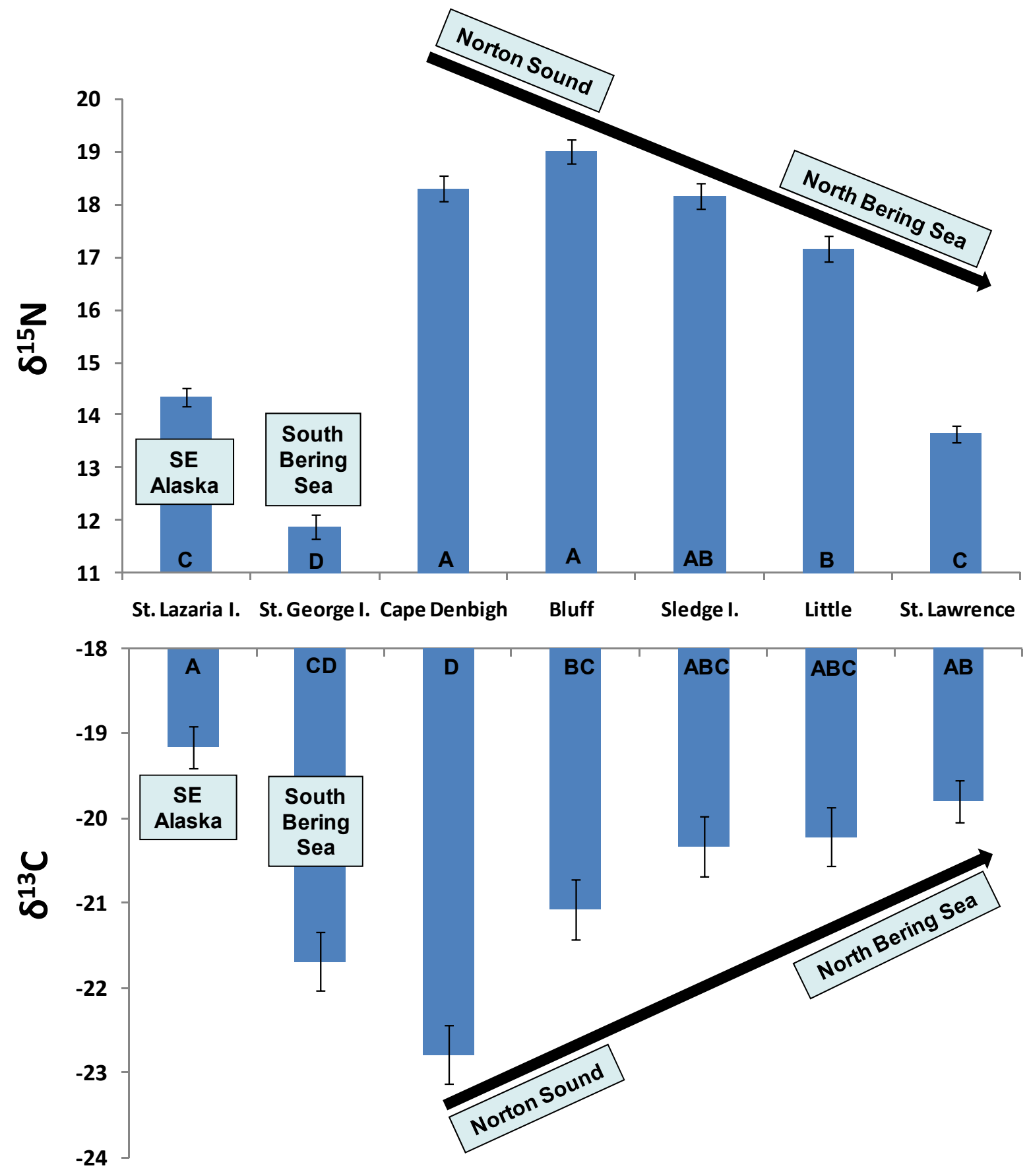

Figure 13. $\delta^{15} \mathrm{~N}$ and $\delta^{13} \mathrm{C}$ gradients between the Norton Sound and northern Bering Sea regions. Bars $=$ mean \pm standard error, and different letters indicate significant differences based on 1-way ANOVA and Tukey tests. 


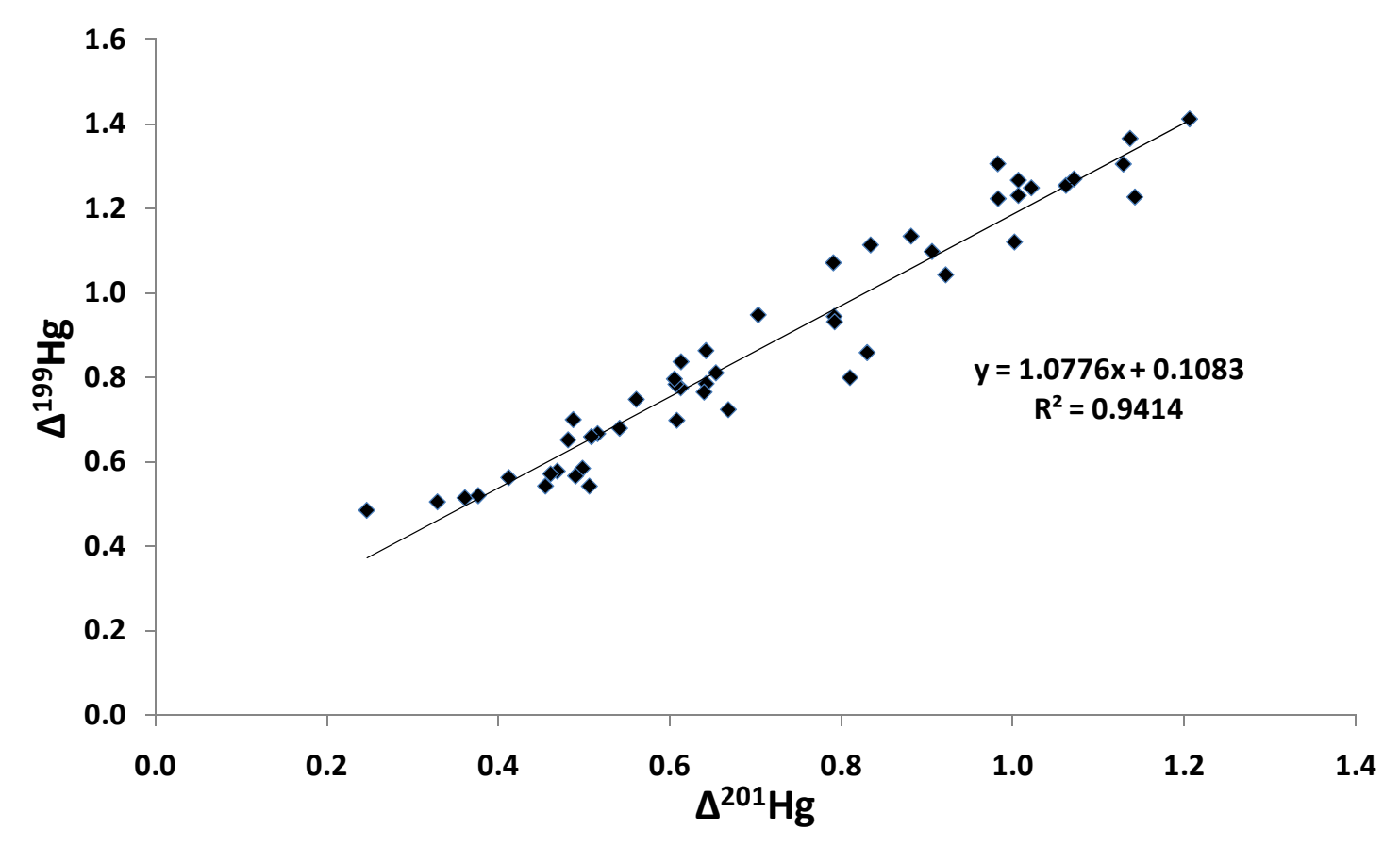

Figure 14. Slope of the linear regression between $\Delta^{199} \mathrm{Hg}$ and $\Delta^{201} \mathrm{Hg}$. This slope is sometimes used to infer the chemical species of $\mathrm{Hg}$ undergoing photoreduction (e.g., see Blum and Berquist 2007, Point et al. 2011). The overall slope of this relationship in this study was 1.08 , which is closer to the experimentally derived value for inorganic $\mathrm{Hg}$ photoreduction (1.0) than for MeHg photoreduction (1.3).

\section{$\underline{\text { Persistent Organic Pollutants (POPs) }}$}

\section{$Q A / Q C$ and General Results}

Percent lipid and mass fractions of organochlorine pesticides, and mass fractions of PBDEs and PCBs in the murre egg control material are listed in Appendices 5 and 6, and colony, species, and year results are summarized in Appendices 7-30 and 31-54, respectively. Values for organochlorine contaminants varied from below detection limits $\left(<0.00117 \mathrm{ng} \mathrm{g}^{-1}\right)$ to $391 \mathrm{ng} \mathrm{g}^{-1}$ wet mass for $4,4^{\prime}$-DDE in one glaucous gull egg from Stuart Island in Norton Sound (egg number 1420; see Appendices 2 and 29). RSDs at the colonies varied between $0.99 \%$ and $210 \%$ $($ mean $=39.5 \%)$.

While most control material levels were within consensus value ranges (Appendices 5 and 6), many of the PCBs levels were lower, as reported by an earlier study (Vander Pol 2007). Also, as reported before, PCB congeners 199 and 201 were above consensus values because of interfering peaks. The duplicate analyses of gull eggs 1340 and 1403 (see above and Appendix 2) resulted in differences of less that $10 \%$, indicating our fresh homogenization procedures produced wellmixed samples (Appendices 22, 27, 46, and 51). 
Although percent lipids were significantly different among colonies (MANOVA $\mathrm{F}_{15,62}=26.1, P$ $<0.0001$ ), they did not differ among the murre nesting locations (Fig. 15). Gulls were lower than murres, and the Safety Sound gull eggs contained the lowest lipid levels.

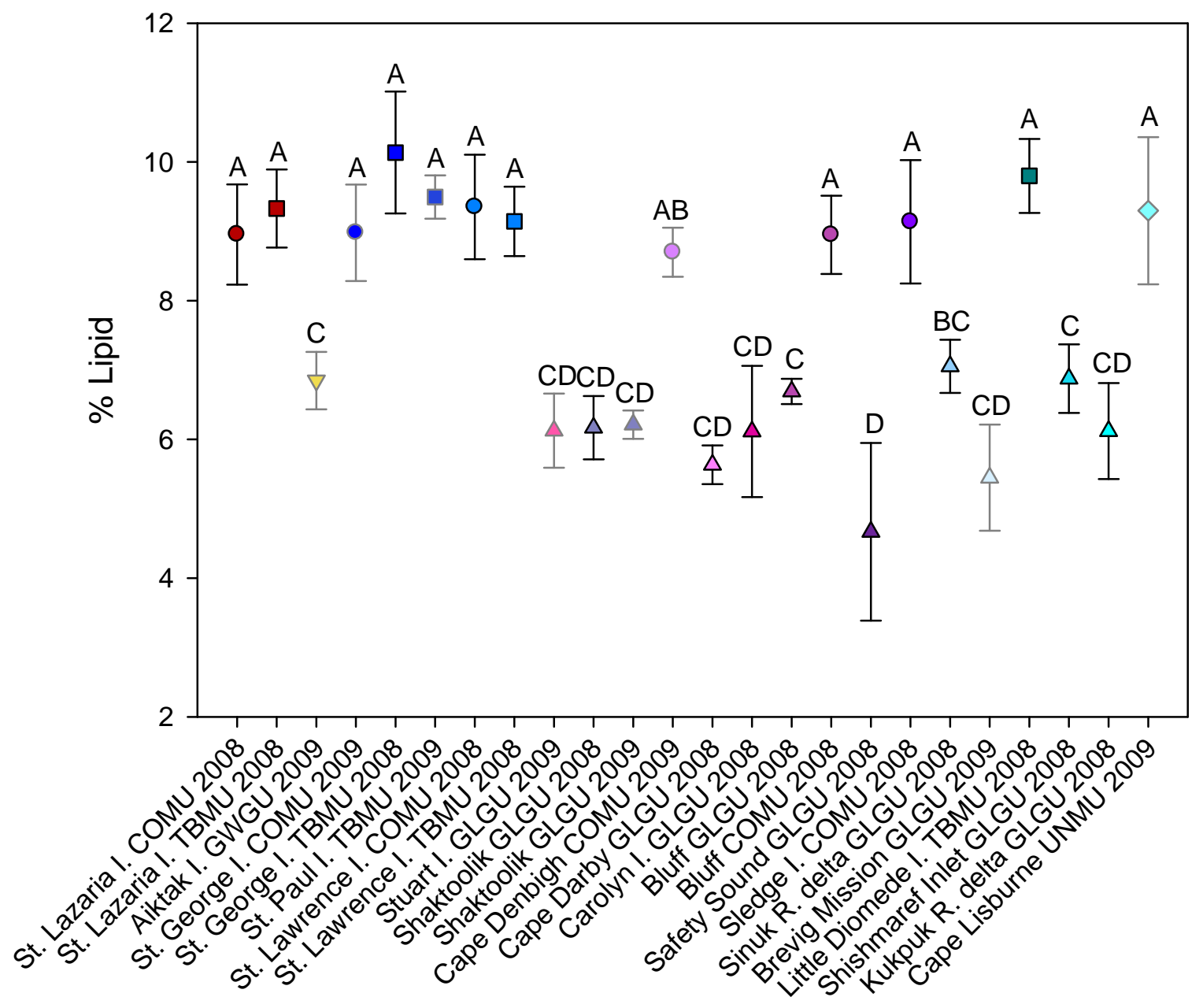

Figure 15. Percent lipid in common murre (COMU), thick-billed murre (TBMU), glaucous gull (GLGU), and glaucous-winged gull (GWGU) eggs collected at 19 Alaskan colonies in 20082009. Significant differences $(P<0.05)$ among sites are shown by different letters (e.g., Bluff GLGU 2008 [C] differed from Safety Sound GLGU 2008 [D]). 


\section{Regional Comparisons}

The Norton Sound common murre eggs from Sledge Island, Bluff, and Cape Denbigh were significantly different from the St. Lawrence and St. George island common murre eggs (Fig. 16; MANOVA $\mathrm{F}_{11,18}=7.12, P<0.0001$ ). Although the Norton Sound cis-nonachlor, HCB, mirex, octacholorstyrene, and BDE 47 levels were higher than those found in the Bering Sea, the remaining compounds did not differ between these regions $(P>0.05)$. However, the Norton Sound (Sinuk River delta, Safety Sound, Bluff, Cape Darby, Shaktoolik, and Carolyn and Stuart islands) and Bering and Chukchi sea (Brevig Mission, Shishmaref Inlet, and Kukpuk River delta) gull eggs contained lower levels of $\beta-\mathrm{HCH}$, cis-nonachlor, $\mathrm{HCB}$, heptachlor epoxide, mirex, oxychlordane, $\Sigma \mathrm{PCBs}$, and BDE 47 than the Bering and Chukchi sea eggs did (Fig. 16; MANOVA $\left.\mathrm{F}_{11,40}=5.25, P<0.0001\right)$.

We ran a MANOVA on all of the colonies and it was also significant $\left(\mathrm{F}_{253,855}=5.94, P<\right.$ $0.0001)$, as were all of the ANOVAs run on individual compounds $(P<0.0001$; see Table 6$)$.

The first two principal components (PC) of the PCA accounted for $65.0 \%$ of the total variation (Fig. 17). The first PC explained $48.1 \%$ of the variation and was separated by the organochlorine pesticides: octachlorostyrene, $\mathrm{HCB}$, pentachlorobenzene, and $\beta-\mathrm{HCH}$ on the lower end, and the penta- to hepta-PCB congeners on the upper end. The second PC explained another $16.9 \%$ of the variation and had higher proportions of heptachlor epoxide, mirex, oxychlordane, cis-nonachlor, and penta-PCB congeners on the higher end, and 4,4'-DDE and hexa- to octa-PCB congeners on the lower end.

\section{Species Comparisons}

Species differences were significant (MANOVA $\mathrm{F}_{11,18}=2.62, P=0.0339$ ), with levels of heptachlor epoxide, pentachlorobenzene, and $\beta-\mathrm{HCH}$ higher in the common murre eggs than in the thick-billed murre eggs. We checked to see if this pattern was also present among the colonies, but only the St. George Island eggs differed between species. However, these eggs were collected in different years (2008 and 2009), and when we removed this location from our calculations, the MANOVA was no longer significant $\left(\mathrm{F}_{11,8}=2.46, P=0.106\right)$.

\section{Temporal Comparisons}

Temporal variations at St. George and St. Lazaria islands are shown in Fig. 18. Declines in the levels of 4,4'-DDE and mirex in the St. Lazaria common and thick-billed murre eggs and HCB, and oxychlordane in the St. George and St. Lazaria island thick-billed murre eggs were significant, and the increase in mirex in the St. George Island thick-billed murre eggs was also significant. 


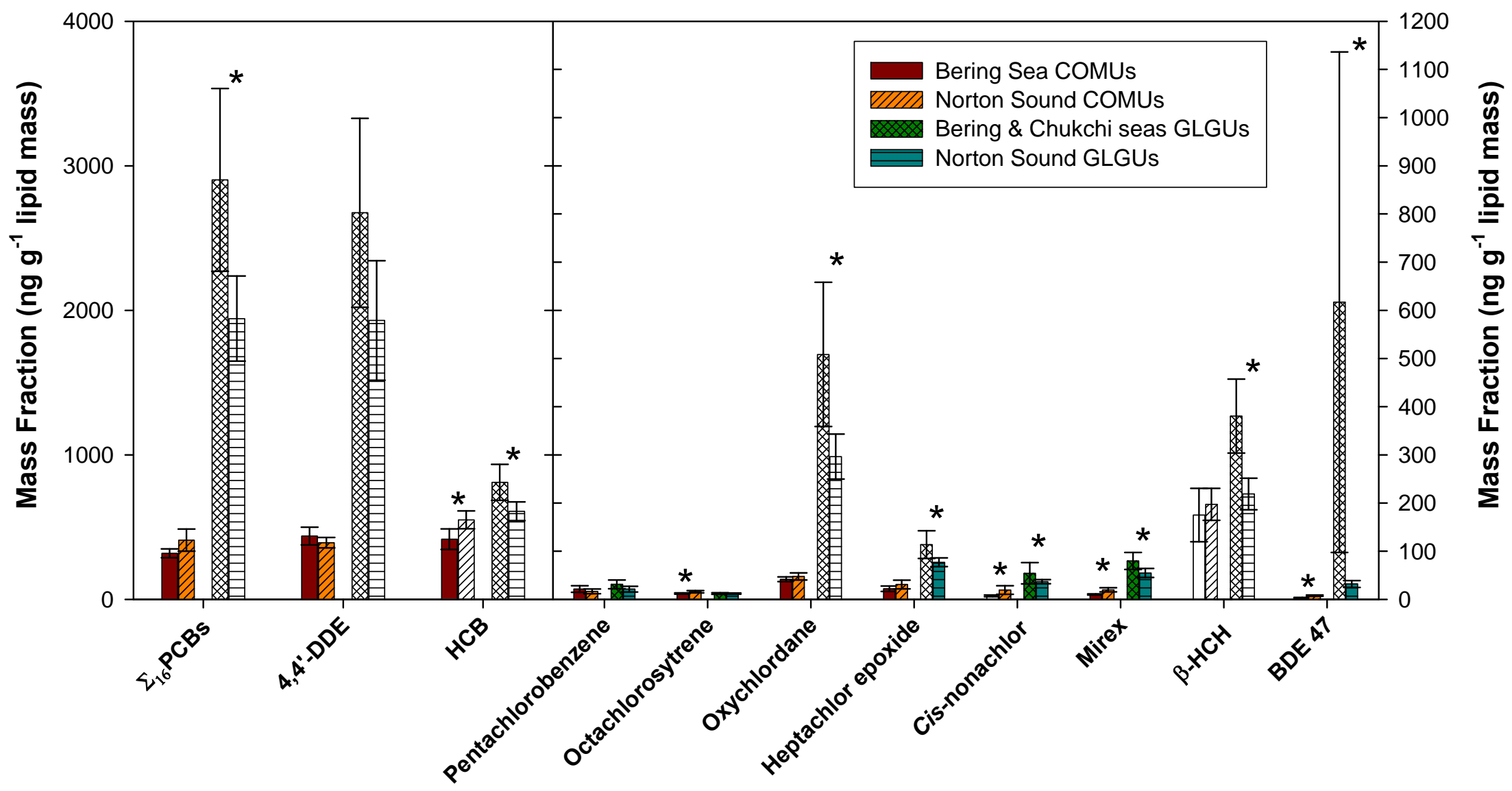

Figure 16. Geographic comparisons (means $\pm 95 \%$ confidence intervals) for common murre (COMU) eggs collected from Bering Sea (St. George and St. Lawrence islands) and Norton Sound (Bluff, Cape Denbigh, and Sledge Island) colonies, and glaucous gull (GLGU) eggs collected from Chukchi Sea (Kukpuk River delta, Shishmaref Inlet), Bering Sea (Brevig Mission), and Norton Sound (Sinuk River delta, Safety Sound, Bluff, Cape Darby, Shaktoolik, and Carolyn and Stuart islands) nesting locations. Asterisks (*) indicate the MANOVAs were significant $(P<0.05)$. 


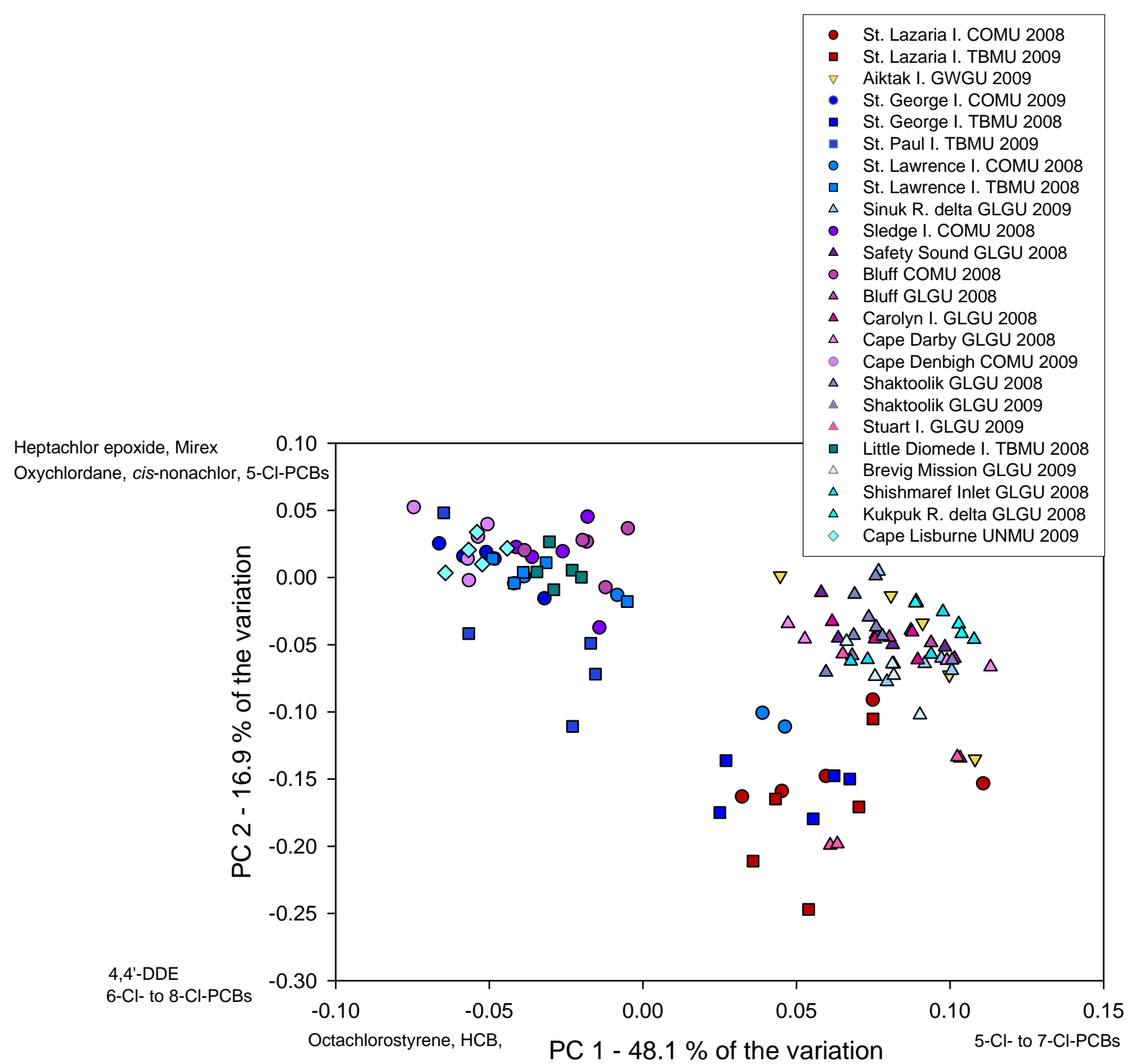

Figure 17. Principal components analyses for organochlorine pesticides and polychlorinated biphenyls (PCBs) in common murre (COMU), thick-billed murre (TBMU), glaucous gull (GLGU), and glaucous-winged gull (GWGU) eggs collected at 19 Alaskan colonies in 20082009. Compounds that contribute to the loadings are shown along the axes. 
Table 6. Mass fractions (ng g ${ }^{-1}$ lipid mass) of major contaminants in murre and gull eggs (means \pm confidence intervals and ranges are shown in parentheses; colonies not sharing letters differed significantly based on Tukey-Kramer Post-hoc tests).

\begin{tabular}{|c|c|c|c|c|c|c|c|c|c|c|c|c|}
\hline \multirow{4}{*}{$\begin{array}{l}\text { F-Ratio } \\
P \\
\text { St. Lazaria I. COMU } 2008\end{array}$} & \multirow{2}{*}{\multicolumn{2}{|c|}{$\begin{array}{c}\text { BDE } 47 \\
5.25\end{array}$}} & \multicolumn{2}{|l|}{$\Sigma_{16} \mathrm{PCBs}$} & \multicolumn{2}{|l|}{ 4,4'-DDE } & \multicolumn{2}{|l|}{$\beta-\mathrm{HCH}$} & \multicolumn{2}{|l|}{$\mathrm{HCB}$} & \multicolumn{2}{|c|}{ Pentachlorobenzene } \\
\hline & & & 7.34 & & 4.88 & & 4.53 & & 6.84 & & 15.4 & \\
\hline & $<0.0001$ & & $<0.0001$ & & $<0.0001$ & & $<0.0001$ & & $<0.0001$ & & $<0.0001$ & \\
\hline & $\begin{array}{c}159 \pm 176 \\
(39.8-515)\end{array}$ & $\mathrm{B}$ & $\begin{array}{c}1051 \pm 778 \\
(408-2565)\end{array}$ & B-F & $\begin{array}{c}1580 \pm 810 \\
(938-3180)\end{array}$ & $\mathrm{AB}$ & $\begin{array}{c}144 \pm 40 \\
(81.9-210)\end{array}$ & $\mathrm{C}$ & $\begin{array}{c}280 \pm 53 \\
(214-370)\end{array}$ & F-G & $\begin{array}{c}7.34 \pm 1.3 \\
(6.06-9.65)\end{array}$ & \\
\hline St. Lazaria I. TBMU2008 & $\begin{array}{c}159 \pm 176 \\
(39.8-515)\end{array}$ & B & $\begin{array}{c}648 \pm 255 \\
(345-1035)\end{array}$ & C-F & $\begin{array}{c}1490 \pm 370 \\
(1110-2140)\end{array}$ & $\mathrm{AB}$ & $\begin{array}{c}107 \pm 27 \\
(66.8-151)\end{array}$ & C & $\begin{array}{c}280 \pm 14 \\
(267-308)\end{array}$ & F-G & $\begin{array}{c}8.30 \pm 2.0 \\
(5.48-11.1)\end{array}$ & \\
\hline Aiktak I. GWGU 2009 & $\begin{array}{c}31.8 \pm 25 \\
(6.78-79.0)\end{array}$ & $\mathrm{B}$ & $\begin{array}{l}1510 \pm 1092 \\
(343-3578)\end{array}$ & B-F & $\begin{array}{l}1720 \pm 1800 \\
(249-5230)\end{array}$ & $\mathrm{AB}$ & $\begin{array}{c}209 \pm 110 \\
(62.0-406)\end{array}$ & $\mathrm{BC}$ & $\begin{array}{c}299 \pm 110 \\
(90.8-390)\end{array}$ & E-G & $\begin{array}{c}18.4 \pm 7.6 \\
(8.42-28.1)\end{array}$ & D-H \\
\hline St. George I. COMU 2009 & $\begin{array}{c}3.63 \pm 1.3 \\
(1.22-5.20)\end{array}$ & $\mathrm{B}$ & $\begin{array}{c}280 \pm 21 \\
(240-296)\end{array}$ & E-F & $\begin{array}{c}389 \pm 33 \\
(335-441)\end{array}$ & B & $\begin{array}{c}245 \pm 60 \\
(175-341)\end{array}$ & $\mathrm{A}-\mathrm{C}$ & $\begin{array}{c}457 \pm 28 \\
(418-504)\end{array}$ & C-G & $\begin{array}{c}28.7 \pm 9.7 \\
(12.7-41.3)\end{array}$ & $\mathrm{C}-\mathrm{F}$ \\
\hline St. George I. TBMU 2008 & $\begin{array}{c}3.89 \pm 1.9 \\
(1.80-6.63)\end{array}$ & $\mathrm{B}$ & $\begin{array}{c}415 \pm 99 \\
(294-581)\end{array}$ & D-F & $\begin{array}{c}1000 \pm 110 \\
(867-1170)\end{array}$ & B & $\begin{array}{c}82.6 \pm 17 \\
(59.3-108)\end{array}$ & $\mathrm{C}$ & $\begin{array}{c}234 \pm 50 \\
(175-292)\end{array}$ & $\mathrm{G}$ & $\begin{array}{c}6.47 \pm 2.8 \\
(1.55-9.81)\end{array}$ & \\
\hline St. Paul I. TBMU 2009 & $\begin{array}{c}2.20 \pm 1.2 \\
(0.847-3.79)\end{array}$ & B & $\begin{array}{c}220 \pm 63 \\
(120-296)\end{array}$ & $\mathrm{F}$ & $\begin{array}{c}497 \pm 170 \\
(303-809)\end{array}$ & B & $\begin{array}{c}160 \pm 55 \\
(84.7-256)\end{array}$ & C & $\begin{array}{c}376 \pm 87 \\
(261-524)\end{array}$ & D-G & $\begin{array}{c}31.8 \pm 11 \\
(16.1-45.6)\end{array}$ & C-E \\
\hline St. Lawrence I. COMU 2008 & $\begin{array}{c}3.18 \pm 0.58 \\
(2.44-3.93)\end{array}$ & B & $\begin{array}{c}357 \pm 28 \\
(327-402)\end{array}$ & $\mathrm{EF}$ & $\begin{array}{c}488 \pm 110 \\
(378-631)\end{array}$ & B & $\begin{array}{c}105 \pm 29 \\
(65.6-136)\end{array}$ & C & $\begin{array}{l}376 \pm 140 \\
(205-558)\end{array}$ & D-G & $\begin{array}{c}14.3 \pm 4.5 \\
(9.95-21.0)\end{array}$ & E-H \\
\hline St. Lawrence I. TBMU 2008 & $\begin{array}{c}3.78 \pm 1.9 \\
(1.80-6.25)\end{array}$ & $\mathrm{B}$ & $\begin{array}{c}384 \pm 79 \\
(256-461)\end{array}$ & $\mathrm{EF}$ & $\begin{array}{c}412 \pm 81 \\
(280-523)\end{array}$ & $\mathrm{B}$ & $\begin{array}{c}117 \pm 67 \\
(0.920-205)\end{array}$ & C & $\begin{array}{c}536 \pm 57 \\
(452-623)\end{array}$ & A-G & $\begin{array}{c}13.8 \pm 2.9 \\
(10.1-18.9)\end{array}$ & E-H \\
\hline Sinuk R. delta GLGU 2008 & $\begin{array}{c}24.7 \pm 4.8 \\
(15.8-30.2)\end{array}$ & B & $\begin{array}{c}1837 \pm 460 \\
(1370-2565)\end{array}$ & A-F & $\begin{array}{c}1580 \pm 410 \\
(1030-2160)\end{array}$ & $\mathrm{AB}$ & $\begin{array}{c}199 \pm 78 \\
(111-327)\end{array}$ & $\mathrm{C}$ & $\begin{array}{c}513 \pm 86 \\
(376-632)\end{array}$ & B-G & $\begin{array}{c}9.85 \pm 3.3 \\
(3.37-12.8)\end{array}$ & F-H \\
\hline Sledge I. COMU 2008 & $\begin{array}{c}9.06 \pm 1.8 \\
(6.68-11.2)\end{array}$ & B & $\begin{array}{c}448 \pm 135 \\
(314-658)\end{array}$ & D-F & $\begin{array}{c}426 \pm 46 \\
(360-469)\end{array}$ & B & $\begin{array}{c}202 \pm 70 \\
(121-332)\end{array}$ & $\mathrm{C}$ & $\begin{array}{c}557 \pm 120 \\
(390-726)\end{array}$ & A-G & $\begin{array}{c}11.7 \pm 2.1 \\
(7.96-13.9)\end{array}$ & F-H \\
\hline Safety Sound GLGU 2008 & $\begin{array}{c}31.6 \pm 8.3 \\
(20.1-39.7)\end{array}$ & B & $\begin{array}{c}2256 \pm 818 \\
(1139-2900)\end{array}$ & A-E & $\begin{array}{c}1990 \pm 840 \\
(867-2800)\end{array}$ & $\mathrm{AB}$ & $\begin{array}{c}297 \pm 190 \\
(142-559)\end{array}$ & $\mathrm{A}-\mathrm{C}$ & $\begin{array}{c}832 \pm 320 \\
(564-1240)\end{array}$ & A-C & $\begin{array}{c}12.8 \pm 5.6 \\
(8.16-20.9)\end{array}$ & E-H \\
\hline Bluff COMU 2008 & $\begin{array}{c}8.01 \pm 2.8 \\
(3.78-12.5)\end{array}$ & B & $\begin{array}{c}490 \pm 146 \\
(311-762)\end{array}$ & $\mathrm{D}-\mathrm{F}$ & $\begin{array}{c}405 \pm 79 \\
(316-555)\end{array}$ & B & $\begin{array}{c}203 \pm 58 \\
(106-263)\end{array}$ & $\mathrm{C}$ & $\begin{array}{c}536 \pm 160 \\
(385-846)\end{array}$ & A-G & $\begin{array}{c}9.76 \pm 2.4 \\
(7.33-14.2)\end{array}$ & GH \\
\hline Bluff GLGU 2008 & $\begin{array}{c}72.4 \pm 37 \\
(19.4-106)\end{array}$ & B & $\begin{array}{c}1702 \pm 486 \\
(1195-2357)\end{array}$ & A-F & $\begin{array}{c}1430 \pm 360 \\
(1050-1900)\end{array}$ & $\mathrm{AB}$ & $\begin{array}{c}182 \pm 53 \\
(125-241)\end{array}$ & $\mathrm{C}$ & $\begin{array}{c}533 \pm 84 \\
(453-654)\end{array}$ & A-G & $\begin{array}{c}14.1 \pm 2.9 \\
(10.9-17.6)\end{array}$ & E-H \\
\hline Carolyn I.GLGU 2008 & $\begin{array}{c}21.8 \pm 7.7 \\
(13.1-35.6)\end{array}$ & B & $\begin{array}{c}1811 \pm 406 \\
(1144-2295)\end{array}$ & A-F & $\begin{array}{c}1580 \pm 360 \\
(986-1960)\end{array}$ & $\mathrm{AB}$ & $\begin{array}{c}188 \pm 49 \\
(107-244)\end{array}$ & $\mathrm{C}$ & $\begin{array}{c}580 \pm 120 \\
(380-714)\end{array}$ & A-G & $\begin{array}{c}9.64 \pm 5.5 \\
(3.77-17.9)\end{array}$ & GH \\
\hline Cape Darby GLGU 2008 & $\begin{array}{c}21.4 \pm 6.0 \\
(12.1-29.7)\end{array}$ & B & $\begin{array}{c}1863 \pm 817 \\
(982-3393)\end{array}$ & A-F & $\begin{array}{c}1720 \pm 570 \\
(990-2740)\end{array}$ & $\mathrm{AB}$ & $\begin{array}{c}186 \pm 25 \\
(138-208)\end{array}$ & $\mathrm{C}$ & $\begin{array}{c}582 \pm 62 \\
(488-682)\end{array}$ & A-G & $\begin{array}{c}10.7 \pm 1.6 \\
(7.58-12.3)\end{array}$ & F-H \\
\hline Cape Denbigh COMU 2009 & $\begin{array}{c}6.06 \pm 1.7 \\
(3.51-8.95)\end{array}$ & $\mathrm{B}$ & $\begin{array}{c}292 \pm 40 \\
(256-344)\end{array}$ & $\mathrm{EF}$ & $\begin{array}{c}343 \pm 42 \\
(269-386)\end{array}$ & B & $\begin{array}{c}187 \pm 55 \\
(92.3-241)\end{array}$ & C & $\begin{array}{c}558 \pm 35 \\
(493-596)\end{array}$ & A-G & $\begin{array}{c}28.3 \pm 5.2 \\
(19.6-33.7)\end{array}$ & C-G \\
\hline Shaktoolik GLGU 2008 & $\begin{array}{c}27.5 \pm 5.6 \\
(20.2-34.2)\end{array}$ & $\mathrm{B}$ & $\begin{array}{c}2103 \pm 627 \\
(1384-2827)\end{array}$ & A-F & $\begin{array}{c}1600 \pm 590 \\
(1040-2260)\end{array}$ & $\mathrm{AB}$ & $\begin{array}{c}271 \pm 43 \\
(231-330)\end{array}$ & $\mathrm{A}-\mathrm{C}$ & $\begin{array}{c}784 \pm 190 \\
(555-981)\end{array}$ & A-C & $\begin{array}{c}18.9 \pm 5.2 \\
(12.8-25.2)\end{array}$ & D-H \\
\hline Shaktoolik GLGU 2009 & $\begin{array}{c}33.8 \pm 27 \\
(14.2-86.8)\end{array}$ & B & $\begin{array}{c}1750 \pm 451 \\
(1124-2519)\end{array}$ & A-F & $\begin{array}{c}1870 \pm 440 \\
(1440-2510)\end{array}$ & $\mathrm{AB}$ & $\begin{array}{c}212 \pm 78 \\
(77.9-315)\end{array}$ & $\mathrm{BC}$ & $\begin{array}{c}654 \pm 81 \\
(515-765)\end{array}$ & A-E & $\begin{array}{c}56.2 \pm 14 \\
(38.9-78.3)\end{array}$ & \\
\hline Stuart I. GLGU 2009 & $\begin{array}{c}29.6 \pm 11 \\
(17.5-44.1)\end{array}$ & B & $\begin{array}{l}2267 \pm 1853 \\
(353-4635)\end{array}$ & A-D & $\begin{array}{c}3520 \pm 2600 \\
(1020-6960)\end{array}$ & A & $\begin{array}{c}235 \pm 150 \\
(54.3-416)\end{array}$ & A-C & $\begin{array}{c}466 \pm 260 \\
(133-696)\end{array}$ & C-G & $\begin{array}{c}35.2 \pm 16 \\
(12.9-53.2)\end{array}$ & B-D \\
\hline Little Diomede I. TBMU 2008 & $\begin{array}{c}5.43 \pm 0.82 \\
(4.18-6.76)\end{array}$ & $\mathrm{B}$ & $\begin{array}{c}486 \pm 54 \\
(420-555)\end{array}$ & $\mathrm{D}-\mathrm{F}$ & $\begin{array}{c}496 \pm 30 \\
(448-531)\end{array}$ & B & $\begin{array}{c}196 \pm 19 \\
(166-221)\end{array}$ & $\mathrm{C}$ & $\begin{array}{c}623 \pm 83 \\
(478-713)\end{array}$ & $A-F$ & $\begin{array}{c}16.9 \pm 4.2 \\
(12.3-24.2)\end{array}$ & D-H \\
\hline Brevig Mission GLGU 2009 & $\begin{array}{c}38.1 \pm 6.8 \\
(26.0-46.1)\end{array}$ & $\mathrm{B}$ & $\begin{array}{c}2844 \pm 659 \\
(1751-3676)\end{array}$ & $\mathrm{AB}$ & $\begin{array}{c}3470 \pm 1100 \\
(1990-4970)\end{array}$ & A & $\begin{array}{c}448 \pm 120 \\
(229-619)\end{array}$ & A & $\begin{array}{c}876 \pm 190 \\
(527-1090)\end{array}$ & $\mathrm{AB}$ & $\begin{array}{c}53.7 \pm 7.7 \\
(46.3-68.1)\end{array}$ & $\mathrm{AB}$ \\
\hline Shismaref Inlet GLGU 2008 & $\begin{array}{c}284 \pm 505 \\
(20.6-1314)\end{array}$ & $\mathrm{B}$ & $\begin{array}{c}2405 \pm 632 \\
(1655-3497)\end{array}$ & A-C & $\begin{array}{c}2000 \pm 330 \\
(1600-2400)\end{array}$ & $\mathrm{AB}$ & $\begin{array}{c}271 \pm 30 \\
(225-319)\end{array}$ & $\mathrm{A}-\mathrm{C}$ & $\begin{array}{c}667 \pm 61 \\
(582-745)\end{array}$ & A-D & $\begin{array}{c}19.8 \pm 5.0 \\
(11.3-25.8)\end{array}$ & D-H \\
\hline Kukpuk R. delta GLGU 2008 & $\begin{array}{c}1529 \pm 1162 \\
(81.1-2700)\end{array}$ & A & $\begin{array}{c}3457 \pm 1679 \\
(1975-5737)\end{array}$ & A & $\begin{array}{r}2560 \pm 1500 \\
(1280-4660)\end{array}$ & $\mathrm{AB}$ & $\begin{array}{l}421 \pm 170 \\
(273-655)\end{array}$ & $\mathrm{AB}$ & $\begin{array}{c}886 \pm 310 \\
(597-1290)\end{array}$ & A & $\begin{array}{c}20.4 \pm 8.0 \\
(11.3-34.6)\end{array}$ & D-H \\
\hline Cape Lisburne UNMU 2009 & $\begin{array}{c}2.98 \pm 1.6 \\
(1.15-6.05)\end{array}$ & $\mathrm{B}$ & $\begin{array}{c}333 \pm 72 \\
(268-477)\end{array}$ & EF & $\begin{array}{c}437 \pm 65 \\
(322-504)\end{array}$ & B & $\begin{array}{c}216 \pm 60 \\
(154-322)\end{array}$ & $\mathrm{BC}$ & $\begin{array}{c}627 \pm 110 \\
(470-799)\end{array}$ & $A-F$ & $\begin{array}{c}41.5 \pm 9.4 \\
(31.8-57.1)\end{array}$ & A-C \\
\hline
\end{tabular}


Table 6. (Continued).

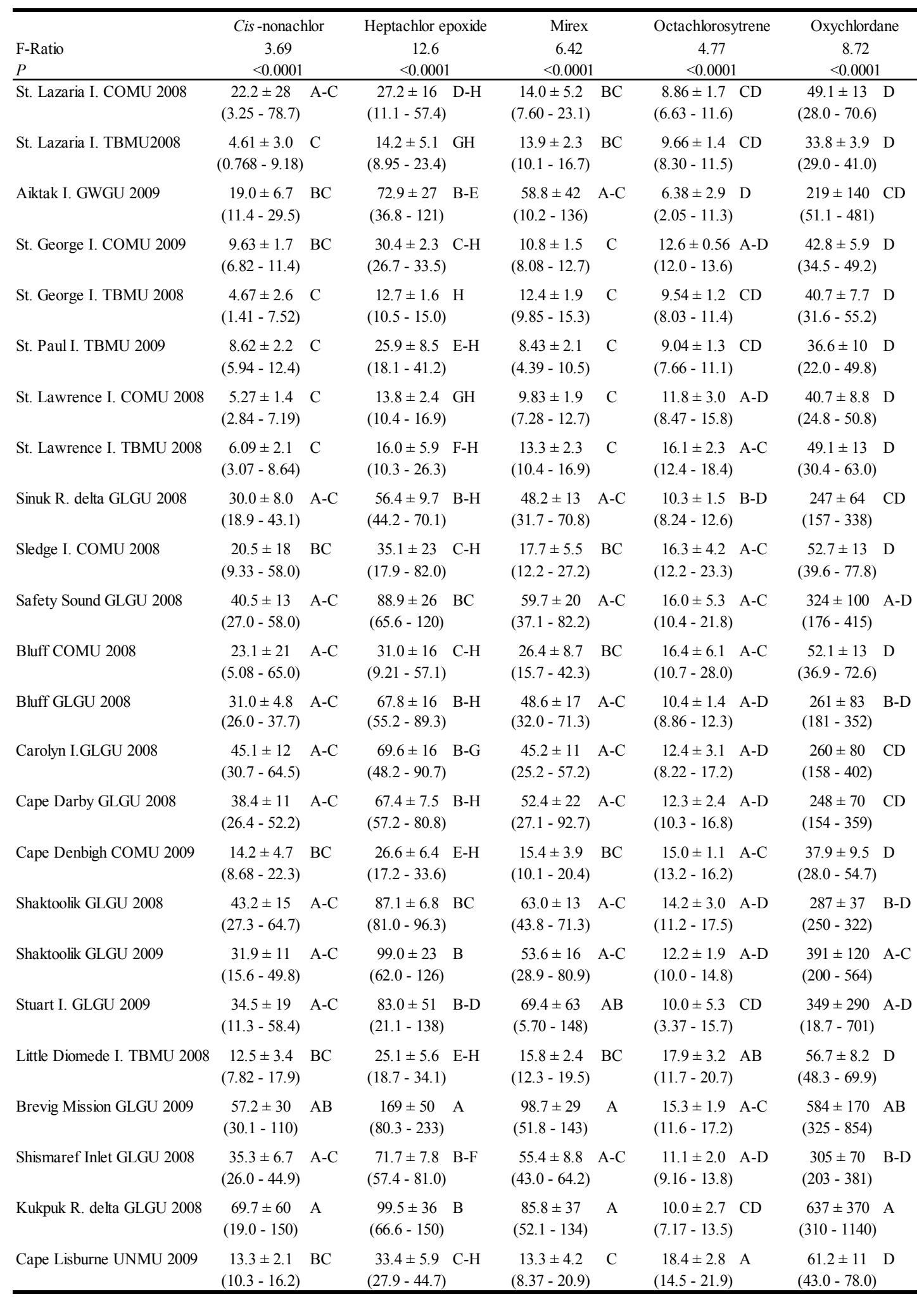



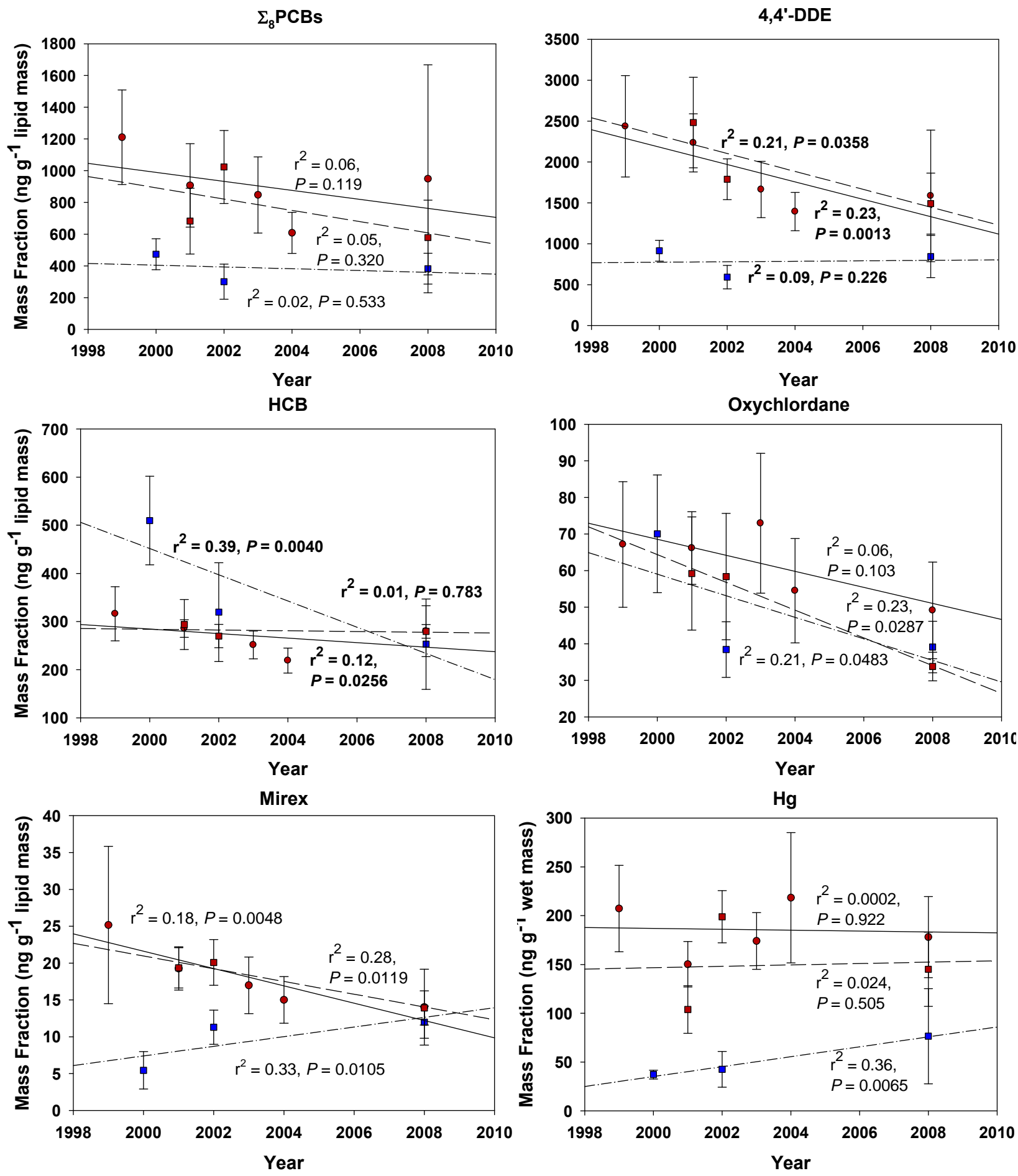

Figure 18. Temporal comparisons (means $\pm 95 \%$ confidence intervals) for St. Lazaria Island common murre (red circles and solid regression lines) and thick-billed murre (red squares and dashed regression lines) eggs and St. George thick-billed murre eggs (blue squares and dashed-dot regression lines). 


\section{Discussion}

Mercury $(\mathrm{Hg})$ and $\mathrm{Hg}$, Carbon (C), and Nitrogen (N) Isotopes

\section{Taxonomic Comparisons of $\mathrm{Hg}$ Levels and $\delta^{15} \mathrm{~N}$ and $\delta^{13} \mathrm{C}$}

The Hg levels found in the Norton Sound, northern Bering Sea, southeastern Bering Sea, and southeastern Gulf of Alaska murre and gull eggs were consistent with the previously reported values from these regions (e.g., see Roseneau et al. 2008, Day et al. 2006, and Day et al. in prep.). Gulls had higher $\mathrm{Hg}$ values than murres did across the entire sampling area, and also within the regions where we obtained both kinds of eggs. Foraging differences between these taxa (see Results above) expose them to different environmental reservoirs of $\mathrm{Hg}$, which affects assimilation rates. The complementary $\delta^{15} \mathrm{~N}$ and $\delta^{13} \mathrm{C}$ data, which reflect the nitrogen and carbon pools that the birds were relying on, support this scenario.

Because many species are euryphagic or have poorly characterized feeding habits, measuring

$\delta^{15} \mathrm{~N}$ is often the most effective method for determining trophic levels of organisms. Numerous food web studies have documented positive relationships between $\mathrm{Hg}$ levels in organisms and the trophic levels (calculated from $\delta^{15} \mathrm{~N}$ ) they were feeding at (e.g., see Jarman et al. 1996, Atwell et al. 1998, Campbell et al. 2005, Chasar et al. 2009, Chumchal and Hambright 2009, Dietz et al. 2009, and Jaegar et al. 2009). This technique of identifying trophic levels is based on the sequential enrichment of ${ }^{15} \mathrm{~N}$ relative to ${ }^{14} \mathrm{~N}$ by $3 \%$ to $5 \%$ at each increasing level. Higher levels of $\delta^{15} \mathrm{~N}$ in the gull eggs indicated these birds were foraging on higher trophic level prey, which typically bioaccumulate more Hg. This trend was present in the southern Bering Sea, but not in the northern Bering and Chukchi Sea, and in Norton Sound, the murre eggs actually had higher average $\delta^{15} \mathrm{~N}$ values than the gull eggs did, indicating that the higher $\mathrm{Hg}$ levels found in these regions were related to other factors, not trophic levels.

$\delta^{13} \mathrm{C}$ has been used to differentiate between terrestrial/benthic and oceanic/pelagic carbon sources. Carbon from terrestrial/benthic sources is typically more depleted (i.e., it has lower, more negative $\delta^{13} \mathrm{C}$ signatures) than carbon from oceanic/pelagic sources (e.g. , see Fernandes and Sicre 2000, Guo et al. 2004, Dunton et al. 2006). Like nitrogen data, $\delta^{13} \mathrm{C}$ signatures can help identify differences in foraging habits of species. However, the relative $\mathrm{Hg}$ uptake by consumers in different habitats is not always well-characterized, and likely varies between given ecosystems and sites. Some studies have shown that benthic habitats can often be more enriched in MeHg than the overlying water columns, and it is also generally accepted that estuarine and coastal environments are efficient at methylating $\mathrm{Hg}$ and may be sources of $\mathrm{MeHg}$ for more oceanic offshore areas (Fitzgerald et al. 2007). This information suggests that, all other things being equal, more depleted terrestrial/benthic $\delta^{13} \mathrm{C}$ signatures should be associated with higher $\mathrm{Hg}$ levels. This is consistent with the trend found in the 2008-2009 data sets, which showed that the higher $\mathrm{Hg}$ levels in the gull eggs were accompanied by more depleted terrestrial $\delta^{13} \mathrm{C}$ signatures than the ones associated with the murre eggs. The exception was the southern Bering Sea, but the gull eggs from this region contained much higher $\delta^{15} \mathrm{~N}$ values, and consequently still had higher Hg levels than the murre eggs did. The combination of trophic levels and habitat/prey selections appear to influence $\mathrm{Hg}$ patterns in taxa, reinforcing the importance of including $\delta^{15} \mathrm{~N}$ and $\delta^{13} \mathrm{C}$ analyses in long-term contaminant monitoring programs. 
Regional Comparisons of Hg Levels and $\delta^{15} \mathrm{~N}$ and $\delta^{13} \mathrm{C}$

Gull eggs did not exhibit any definitive regional Hg trend in Norton Sound, and levels were similar to values found in the northern Bering and Chukchi sea eggs (Fig. 9). As mentioned earlier (see the section on taxonomic comparisons above), gulls are opportunistic, foraging on a broad range of prey, and the abundance and availability of potential food items can also vary markedly among nesting locations. For example, birds nesting at one colony might feed on a combination surface fish in open ocean waters and invertebrates in estuaries and intertidal zones, and birds breeding at another might forage on terrestrial berries and bird eggs and also consume human refuse at a nearby community dump site. These factors almost certainly cause inconsistencies in the integration of $\mathrm{Hg}$, confounding analyses. $\delta^{15} \mathrm{~N}$ was significantly higher in the Norton Sound gull eggs than it was in the northern Bering - Chukchi Sea and southern Bering Sea eggs, but trophic levels did not appear to be related to the Hg levels in these samples. This was further supported by the fact that these variables did not appear to be related in the gull data set. However, we did find significant negative correlations between $\delta^{13} \mathrm{C}$ and $\mathrm{Hg}$, again suggesting that terrestrial/benthic carbon sources were associated with the higher $\mathrm{Hg}$ levels found in these eggs.

The correlation between $\mathrm{Hg}$ and $\delta^{13} \mathrm{C}$ in the gull eggs was subtle in the colony-by-colony data. The most prominent relationships occurred at Aiktak Island and the Kukpuk River delta, where low $\mathrm{Hg}$ and high $\delta^{13} \mathrm{C}$ levels were found in the eggs. Aiktak Island is located just south of the eastern entrance to Unimak Pass near the trajectory of the south-flowing, oceanic Alaskan Stream (e.g., see Reed 1968, Mundy et al. 2010), so it was not surprising that the eggs from this site displayed the most pelagic/oceanic $\delta^{13} \mathrm{C}$ signatures.

The Kukpuk River delta gull colony is located near the base of the Point Hope Spit on a broad expanse of land jutting out into the eastern Chukchi Sea. This nesting location is surrounded by wetlands, but the $\delta^{13} \mathrm{C}$ data suggested the birds breeding at it were relying on more oceanic carbon sources with relatively low $\mathrm{Hg}$ levels. The gull colonies that produced eggs with the most depleted, terrestrial/benthic $\delta^{13} \mathrm{C}$ values were located in Shishmaref Inlet about $120 \mathrm{~km}$ north of Bering Strait along the eastern Chukchi Sea shore; near Brevig Mission on the southwestern side of the Seward Peninsula, about $65 \mathrm{~km}$ east of Bering Strait; in the Sinuk River delta near the northwestern entrance to Norton Sound, about $40 \mathrm{~km}$ west of Nome; on the southern side of Stuart Island in southern Norton Sound, about $65 \mathrm{~km}$ east of the Yukon River's northern mouth; and at Shaktoolik South at the eastern end of Norton Sound, about $20 \mathrm{~km}$ southeast of Cape Denbigh (Fig. 3). The Shishmaref, Brevig Mission, and Shaktoolik South colonies are all located near coastal lagoons and bays that provide estuarine foraging habitats for the nesting birds. Eggs from the other nesting locations along the northern shores of Norton Sound east of Nome (i.e., at Safety Sound, Bluff, Cape Darby, and Carolyn Island in Golovin Bay; see Fig. 3) had intermediate to low $\delta^{13} \mathrm{C}$ values. Eggs from these colonies also had high $\delta^{15} \mathrm{~N}$ signatures (Fig. 9), indicating the birds breeding in this part of the sound were feeding at higher trophic levels, compared to birds nesting at the other locations. However, murre eggs from this same area also had elevated $\delta^{15} \mathrm{~N}$ signatures, suggesting the presence of a locally elevated $\delta^{15} \mathrm{~N}$ source in this part of the embayment's marine ecosystem. 
Gull eggs from the Sinuk River delta and Shaktoolik South colonies had the highest $\mathrm{Hg}$ levels (Figs. 3 and 9). However, these samples did not have distinctive $\delta^{15} \mathrm{~N}$ or $\delta^{13} \mathrm{C}$ signatures, indicating there may be localized sources of $\mathrm{Hg}$ in their vicinities. Although the Sinuk River drains part of the Seward Peninsula where some placer gold mining has occurred, we are not aware of any historical or present day efforts to extract this resource from the Shaktoolik area. More information is required to identify the sources of contamination in these widely separated locales.

The international Arctic Monitoring and Assessment Programme (AMAP) recommended that murre eggs should be used to monitor heavy metals in circumpolar environments because of the distribution and life history traits of these seabirds (AMAP 1998, 1999). Previous studies by STAMP have confirmed that these tissues can be used to identify geographic and temporal differences in $\mathrm{Hg}$ levels in Alaskan marine environments (Day et al. 2006 and Roseneau et al. 2008; also see Day et al. in prep). During this project, we collected murre eggs from several previously sampled locations both inside and outside of the Norton Sound - Bering Strait study area to reconfirm the presence of the large-scale geographic pattern reported in 2008 (Roseneau et al. 2008) and better describe $\mathrm{Hg}$ distribution in this northeastern Bering Sea region. Regional comparisons encompassing all of the sampled murre locations and higher resolution colony-bycolony $\mathrm{Hg}$ isotope information are discussed below.

We previously reported that Gulf of Alaska common and thick-billed murre eggs had higher Hg levels than Bering Sea eggs (Day et al. 2006), and we suggested these regional trends resulted from different $\mathrm{Hg}$ deposition and/or methylation regimes. However, we were not able to eliminate potential food web effects and the possibility of a sampling artifact introduced by a bias toward the presence of more oceanic insular colonies in the Bering Sea and more coastal colonies in the Gulf of Alaska. We recently began addressing these issues by analyzing eggs from more sampling sites in Norton Sound and the Bering and Chukchi seas and Gulf of Alaska, and measuring the $\delta^{15} \mathrm{~N}$ and $\delta^{13} \mathrm{C}$ signatures in them to help clarify the effects of trophic position and habitat utilization on $\mathrm{Hg}$ exposure (Day et al. in prep). During this work, we were able to confirm that trophic levels influenced the geographic pattern, and we also discovered that the Gulf of Alaska was apparently richer in $\mathrm{Hg}$ than the Bering Sea. Furthermore, these finding appeared to be independent of the inshore/offshore locations of the colonies, with one exception-Norton Sound. Murre eggs from this northeastern Bering Sea embayment contained higher Hg levels than the eggs from the other northern Bering and Chukchi sea nesting locations (Fig. 6). We hypothesized that the higher Norton Sound values might be the result of the Yukon River outflow and the inputs from some of the smaller rivers draining the south side of the Seward Peninsula, and/or the historical placer gold mining activities that occurred along these smaller drainages and the northern shores of this coastal embayment.

The geographic patterns in the murres eggs collected for this study corroborated the findings of Day et al. (2006) and Day et al. (in prep.). Eggs from St. Lazaria Island in the Gulf of Alaska and Cape Denbigh, Bluff, and Sledge Island in Norton Sound had the highest Hg levels, and eggs from the southern Bering Sea and northern Bering and Chukchi sea colonies had the lowest levels (Fig. 6). Mean Hg values in the 2005 Cape Denbigh, Bluff, and Sledge Island eggs were $185 \mathrm{ng} \mathrm{g}^{-1}, 163 \mathrm{ng} \mathrm{g}^{-1}$, and $122 \mathrm{ng} \mathrm{g}^{-1}$, respectively. Eggs collected from these same nesting locations in 2008-2009 had only slightly lower levels $\left(132 \mathrm{ng} \mathrm{g}^{-1}, 123 \mathrm{ng} \mathrm{g}^{-1}\right.$, and $75 \mathrm{ng} \mathrm{g}^{-1}$, 
respectively), and they displayed the same progressively declining east-to-west trends in values (Fig. 13). Correlations between $\mathrm{Hg}$ and $\delta^{15} \mathrm{~N}$ levels were significant across all regions, indicating that trophic positions were influencing the geographic pattern. Eggs from the southern Bering Sea not only had the lowest $\mathrm{Hg}$ levels, but they also had the lowest $\delta^{15} \mathrm{~N}$ values (Figs. 6 and 7). This was consistent with information suggesting murres tend to feed more heavily on invertebrates in this area (Coyle et al. 1992), and this was also supported by the relatively depleted $\delta{ }^{13} \mathrm{C}$ levels, which indicated the presence of more benthic sources of carbon near the insular colonies. This same trophic information might also explain the higher $\mathrm{Hg}$ levels in the Norton Sound eggs, which also had the highest $\delta^{15} \mathrm{~N}$ values (Fig. 7 and Appendix 3). However, Schell et al. (1998) reported a geographic gradient in baseline zooplankton $\delta^{15} \mathrm{~N}$ levels ranging from $5.8 \%$ in the southern Bering Sea to $10.5 \%$ in the Chukchi Sea. We cannot quantitatively adjust the Norton Sound $\delta^{15} \mathrm{~N}$ values because there are no corresponding zooplankton data currently available from this region. However, some evidence suggests that the elevated $\delta^{15} \mathrm{~N}$ levels in Norton Sound may be caused by different baseline nitrogen sources, which may in turn mean the elevated $\mathrm{Hg}$ values are not entirely a function of the trophic level. This possibility is supported by the fact that the nearby colonies in the northern Bering and Chukchi seas also have higher $\delta^{15} \mathrm{~N}$ values and lower $\mathrm{Hg}$ levels, relative to the Gulf of Alaska (Figs. 6 and 7). Furthermore, the Norton Sound eggs also contained the highest $\delta^{15} \mathrm{~N}$ values (Fig. 7), indicating that there was an ecosystem-wide elevation in $\delta^{15} \mathrm{~N}$ levels. This broad-scale regional information lends additional confidence to our conclusion that $\mathrm{Hg}$ values are higher in Norton Sound than in the nearby northern Bering and Chukchi sea regions.

The murre egg $\delta^{13} \mathrm{C}$ signatures also displayed distinct regional trends (Fig. 8). As mentioned above, samples from the southern Bering Sea colonies had surprisingly depleted $\delta^{13} \mathrm{C}$ levels, given their proximity to the Bering Shelf break (Fig. 8 and Appendix 3; also see Fig. 1 in Springer and Roseneau 1985). These low values are probably related to the amounts and types of invertebrates taken by murres nesting at these locations. The highest $\delta^{13} \mathrm{C}$ sig natures were found in the St. Lazaria Island eggs in southeastern Alaska, where the dominant oceanographic features are the Alaska Current and a narrow band of continental shelf that only extends about $20 \mathrm{~km}$ offshore (e.g., see Mundy et al. 2010). The northern Bering and Chukchi sea murre eggs had intermediate $\delta^{13} \mathrm{C}$ values (Fig. 8 and Appendix 3). Colonies in these regions are exposed to Anadyr Current waters, which are cold, saline, and nutrient rich (e.g., see Springer et al. 1987, Woodgate et al. 1995, Schell et al. 1998), and Alaska Coastal Current waters, which are relatively warm, fresh, and poor in nutrients (e.g., see Coachman et al. 1975, Springer et al. 1987, Elphick and Hunt 1993). In contrast, Norton Sound receives more direct carbon inputs from the Yukon River and some of the smaller drainages within the embayment (Zou et al. 2006). In summary, the combined $\delta^{13} \mathrm{C}, \delta^{15} \mathrm{~N}$, and $\mathrm{Hg}$ data provide strong evidence that Norton Sound has a unique $\mathrm{Hg}$ regime, and this information helped us select which colonies to check for $\mathrm{Hg}$ isotopes and explore the mechanisms behind these patterns.

\section{Hg Isotopes}

NPRB Project 822 was designed to improve understanding of the distribution of $\mathrm{Hg}$ contamination in Norton Sound and the environmental factors that might be contributing to the 
elevated levels of this potentially harmful pollutant that was found in the region's murre eggs during a previous study (Roseneau et al. 2008).

Based on the $\mathrm{Hg}$ levels and stable carbon and nitrogen isotope signatures, it was evident that Norton Sound differed oceanographically from other regions in the study area (i.e., the northern Bering and Chukchi seas). We analyzed the murre eggs from the seven representative colonies for stable $\mathrm{Hg}$ isotopes to find out if $\mathrm{Hg}$ fractionation patterns could be used to help identify unique $\mathrm{Hg}$ signatures in the study area (Table 4 and Appendix 4). Given the potential that historical and current gold mining activities and outflows from the Yukon River and some of the smaller drainages might have influenced isotope levels in the Norton Sound, we chose eggs from nesting locations that would give us gradients running westward and northward from the eastern end of the sound into the northern Bering Sea and Bering Strait area. The colonies included Cape Denbigh at Norton Sound's eastern end; Bluff at its mid-point along its northern shore; Sledge Island near its northwestern entrance, where the Yukon River outflow becomes entrained in the northward flowing Alaska Coastal Current (e.g., see Springer et al. 1984, Roseneau et al. 2000; Little Diomede Island, where the waters from Norton Sound become diluted by the Alaska Coastal Current and pass through Bering Strait (e.g., see Coachman et al. 1975); and St. Lawrence Island, which is at the same latitude as Norton Sound, but lies about $200 \mathrm{~km}$ offshore near the more oceanic, nutrient-rich waters of the Anadyr Current (Schell et al. 1998). We also included murre eggs from St. George Island in the southeastern Bering Sea and St. Lazaria Island in the southeastern Gulf of Alaska in the $\mathrm{Hg}$ isotope analyses to increase geographic coverage (Figs. 1 and 3).

The magnitude and pattern of $\delta^{202} \mathrm{Hg}$ and $\Delta^{199} \mathrm{Hg}$ that we found at these colonies was similar to recently published information on eggs obtained at St. Lazaria, St. George, and St. Lawrence island in 1999-2002 (Point et al. 2011). This was encouraging, because it demonstrated that the $\mathrm{Hg}$ isotope patterns reflected the general conditions found in these marine environments annually. Point et al. (2011) reported that $\delta^{202} \mathrm{Hg}$ increased with trophic level at these and other colonies. Other author also reported that $\delta^{202} \mathrm{Hg}$ was positively correlated with trophic level or $\delta^{15} \mathrm{~N}$, and suggested that there may be physiological preferences for the assimilation or excretion of $\mathrm{Hg}$ isotopes by mass (e.g., see Bergquist and Blum 2007, Laffont et al. 2009, Perrot et al. 2010). Based on this information, it appears that the heavier $\mathrm{Hg}$ isotopes like $\delta^{202} \mathrm{Hg}$ may become enriched in nitrogen, making them useful for tracing the flow of $\mathrm{Hg}$ through food webs. We did not find this correlation in the 2008-2009 data set, but when we included the 1999-2002 information from the three previously studied nesting locations, we found a significant difference between $\delta^{202} \mathrm{Hg}$ and $\delta^{15} \mathrm{~N}(P=0.003)$, which confirmed earlier findings. We also discovered a significant negative relationship between $\delta^{202} \mathrm{Hg}$ and $\delta^{15} \mathrm{~N}(P=0.002)$ at the Norton Sound colonies, which are closely associated with coastal regimes. This negative relationship may be the result of geographically variable sources of MDF that are stronger than, and contrary to, trophic-related fractionations.

MDF can be induced by photoreduction of $\mathrm{Hg}^{+2}$ or $\mathrm{MeHg}$, microbial reduction of $\mathrm{Hg}^{+2}$, or microbial degradation of MeHg (e.g., see Bergquist and Blum 2007, Kritee et al. 2007, Yang and Sturgeon 2009). Gradients in water chemistry parameters such as dissolved organic carbon and nitrogen, salinity, temperature, turbidity, and irradiance are likely candidates that may also contribute to in-situ differences in MDF fractionation among areas. If in-situ fractionation was 
involved in the negative relationship between $\delta^{202} \mathrm{Hg}$ and $\delta^{15} \mathrm{~N}$ in coastal Norton Sound, the exvivo and in-vivo MDF processes may prove to be equally important considerations when using birds or fish for biomonitoring purposes. Although it is possible to generalize about the processes that the $\delta^{202} \mathrm{Hg}$ signatures might actually represent, the real value of these data may simply be the knowledge of their directions and magnitudes in varying circumstances.

$\Delta^{199} \mathrm{Hg}$ followed a similar pattern, but it displayed an even more distinctive geographic gradient, with low values deep in Norton Sound at Cape Denbigh that became progressively higher as one moved westward toward the more oceanic waters of the northern Bering Sea (Fig. 12). $\Delta^{199} \mathrm{H}$ was also negatively correlated to $\delta^{15} \mathrm{~N}$, which was contrary to evidence in the literature indicating that MIF is not altered by trophic processes (e.g., see Bergquist and Blum 2007, Laffont et al. 2009, Perrot et al. 2010, Point et al. 2011). This suggests that the negative correlations between $\delta^{15} \mathrm{~N}$ and $\delta^{202} \mathrm{Hg}$ and $\Delta^{199} \mathrm{Hg}$ are circumstantial and that covariates instead of trophic factors are more likely to be the causative factors. As mentioned above, there are many processes known to induce Hg MDF (e.g., see Bergquist and Blum 2007, Kritee et al. 2007, Yang and Sturgeon 2009), or cause other inorganic reactions, including changes in state, valency, complexity, and covalent bonding, which may also be enhanced by organic interactions (Ridley and Stetson 2006). However a combination of laboratory and field observations indicate photoreduction is most likely to be the primary mechanism responsible for MIF in aquatic and atmospheric reservoirs (e.g., see Bergquist and Blum 2007, Carignan et al. 2009, Laffont et al. 2009, Senn et al. 2010, Point et al. 2011). If covariates related to differences in water chemistry are considered (e.g., turbidity, dissolved organic carbon and nitrogen, salinity, temperature, irradiance), turbidity appears to stand out as the only factor that could contribute to the trend we found in Norton Sound. Turbid coastal waters in this shallow embayment could inhibit light penetration, and therefore photoreduction-mediated MIF. This situation has been documented in the Gulf of Mexico (Senn et al. 2010). Samples of coastal fish caught in waters influenced by the Mississippi River plume were compared to samples from offshore species and both $\Delta^{199} \mathrm{Hg}$ and $\delta^{202} \mathrm{Hg}$ were significantly lower in the coastal fish. The lower $\Delta^{199} \mathrm{Hg}$ and $\delta^{202} \mathrm{Hg}$ levels were thought to have resulted from offshore sources of $\mathrm{MeHg}$ becoming methylated in oceanic waters that had undergone more extensive photochemical degradation because of better water clarity and light penetration before becoming part of the oceanic food web.

The Gulf of Mexico scenario might explain the $\Delta^{199} \mathrm{Hg}$ and $\delta^{202} \mathrm{Hg}$ levels that we found in Norton Sound, but other factors might also be involved. Although turbidity could certainly affect the degree of light penetration and photoreduction in this embayment, the amount of irradiance reaching its surface waters would be just as important. Point et al. (2011) reported lower MIF in murre eggs from northern Bering and Chukchi sea colonies, compared to eggs from southern Bering Sea and Gulf of Alaska colonies. These authors attributed the lower MIF in the northern eggs to the presence of seasonal sea-ice at these nesting locations, where birds typically arrive well before local ice cover dissipates and forage in open leads for several weeks before laying eggs. The ice cover serves as an effective barrier to sunlight and prevents photoreduction and ocean-atmosphere processes. We also discovered significantly lower MIF in the Norton Sound and northern Bering Sea murre eggs than in the eggs from the southern Bering Sea and Gulf of Alaska colonies. Although this large scale pattern conforms to the Point et al. (2011) sea-ice hypothesis, the $\Delta^{199} \mathrm{Hg}$ patterns at the northern nesting locations did not. Ice cover typically breaks up and dissipates in Norton Sound before it does at either St. Lawrence or Little Diomede 
islands (Grebmeier et al. 2006 and Zhou et al. 2007). Given this information, it appears that ice cover alone cannot explain the lower MIF in the Norton Sound and northern Bering Sea murre eggs.

Dissolved organic carbon (DOC) is another factor influencing photoreduction that appears to conflict with the $\Delta^{199} \mathrm{Hg}$ patterns that we found at the northern murre colonies. Considerable evidence is available suggesting that DOC levels should be higher in Norton Sound than in more offshore areas influenced by oceanic waters. Water samples taken along a southeastern Bering Sea transect showed that DOC and salinity had an inverse relationship and that values were higher in inner shelf waters than in outer shelf waters (Guo et al. 2004). Several studies support the possibility that Norton Sound DOC is derived from fluvial sources, because arctic rivers typically flush humic substances from the peat and soil deposits they drain (Fernandes and Sicre 2000). In the Yukon River, levels of total organic carbon (TOC) peak during spring snowmelt (Zou et al. 2006) and total annual export flux is about $2 \times 10^{12} \mathrm{~g}$ (Guo and Macdonald 2006). As a consequence, it is not surprising that most organic carbon (OC) found in the coastal sediments is derived from fluvial organic matter. Sediment studies in several of Alaska's major river basins and oceanic environments have shown that Norton Sound's total $n$-alkane levels are higher than they are in the southeastern Bering Sea, the Navarin Basin, the Gulf of Alaska, and Cook Inlet, suggesting that this coastal embayment receives consistently higher OC inputs than other parts of the study area (Venkatesan and Kaplan 1982; $n$-alkanes are strongly correlated with OC). Also, organic materials containing $\mathrm{MeHg}$ and $\mathrm{Hg}$ facilitate $\mathrm{Hg}$ MIF reactions induced by photoreduction in aquatic systems, and laboratory experiments have demonstrated that when $\mathrm{Hg}$ and $\mathrm{MeHg}$ are incubated at higher DOC levels, they exhibit higher MIF (Berquist and Blum 2007). Given this information, if organic-mediated photoreduction really was the key driver behind the Norton Sound $\Delta^{199} \mathrm{Hg}$ values, the higher DOC in this embayment should have enhanced MIF, instead of suppressing it relative to the offshore colonies.

The authors of most recent studies have focused on process-related causes like the ones mentioned above when attempting to explain fractionation patterns in the environment. However, they rarely discuss the potential influences of different source signatures unless they were able to identify discrete $\mathrm{Hg}$ point sources. This seems remiss, because $\mathrm{Hg}$ isotope data can help identify contaminant sources and this information can play important roles in management and remediation planning and decision making. As stated above, the 2008-2009 analyses identified an increasing east-west trend in $\delta^{202} \mathrm{Hg}$ and $\Delta^{199} \mathrm{Hg}$, with the lowest values at Norton Sound's eastern end and the highest values in the northern Bering Sea (Fig. 12). These analyses also revealed that $\delta^{13} \mathrm{C}$ was positively correlated with $\delta^{202} \mathrm{Hg}$ and $\Delta^{199} \mathrm{Hg}$, which implied that a terrestrial carbon source was probably present in Norton Sound where the MDF and MIF were the lowest. These data helped confirm that the outflows from the Yukon River and some of the embayment's smaller drainages dominate its water chemistry. The Yukon River alone contributes about $8 \%$ of the total freshwater entering the Arctic Ocean (Aagaard and Carmack 1989), and it is also the source of about $50 \%$ of Norton Sound's sediments (Atlas et al. 1983). The annual discharge from this major drainage also contains about $4400 \mathrm{~kg}$ of total $\mathrm{Hg}$ and $16 \mathrm{~kg}$ of MeHg (Schuster et al. 2010), and more than $40 \mathrm{ng} / \mathrm{L}$ of these contaminants have been found in water samples taken at its highest flow rates, which is 3 times higher than the Environmental Protection Agency (EPA) aquatic life Hg standard for adverse chronic effects to biota. Four other northern rivers were $5 \%$ to $31 \%$ lower, indicating that the Yukon is clearly the largest single 
point source of $\mathrm{Hg}$ in the region and should be recognized as the major source of this contaminant in western Alaska's marine environments. This information, combined with data on currents and the east-west gradient in Norton Sound's Hg values show that coastal systems can be important sources of $\mathrm{MeHg}$ in marine environments.

However, it should be noted that cinnabar deposits on the southern Seward Peninsula help elevate $\mathrm{Hg}$ levels in nearshore sediments near the Norton Sound murre colonies (Nelson et al. 1975). Also, historical gold mining operations that used large quantities of $\mathrm{Hg}$ were located in many of the smaller drainages flowing into the sound near these nesting locations and these activities are likely to have contributed in some measure to the elevated sediment levels found in the coastal zone between Sledge Island and Cape Denbigh (e.g., the Daniels Creek drainage near Bluff was heavily mined after its discovery in 1905-see Harrison 1905; old corroding $45 \mathrm{~kg}$ iron flasks of liquid mercury were still present in this area in 1968-1971-D.G. Roseneau, pers. obs.). When this information is combined with data on $\delta^{13} \mathrm{C}$ and $\mathrm{Hg}$ and $\mathrm{MeHg}$ levels in the Yukon River outflow, it provides compelling evidence that terrestrial sources are responsible for Norton Sound's elevated $\mathrm{Hg}$ values and for the east-to-west gradient that we found in this coastal embayment.

The fact that the $\delta^{202} \mathrm{Hg}$ and $\Delta^{199} \mathrm{Hg}$ levels also followed this same declining east-to-west trend strongly suggests that the gradient really represents a progression between terrestrial and marine $\mathrm{Hg}$ isotope signatures. We would expect the oceanic and atmospheric reservoirs of $\mathrm{Hg}$ to be well-mixed, and "old" in the sense that they would have had plenty of time for various forms of $\mathrm{Hg}$ reactivity to have taken place (see above). In aquatic biota, fractionation typically has a "heavy" isotope signature-i.e., positive $\delta^{202} \mathrm{Hg}$ - particularly in marine species (e.g., see Senn et al. 2010, Point et al. 2011). Lake and coastal studies have reported mixtures of positive and negative $\delta^{202} \mathrm{Hg}$ (Bergquist and Blum 2007, Laffont et al. 2009, Perrot et al. 2010). In contrast, $\Delta^{199} \mathrm{Hg}$ signatures in aquatic systems have almost invariably been positive anomalies (e.g., see Bergquist and Blum 2007, Laffont et al. 2009, Perrot et al. 2010, Senn et al. 2010, Point et al. 2011), and atmospheric $\mathrm{Hg}$ contains the complementary negative $\Delta^{199} \mathrm{Hg}$ (Carignan et al. 2009) that presumably functions as the opposing end member in ocean-atmosphere exchanges. $\mathrm{Hg}$ isotope patterns in terrestrial geological samples differ from the mobile, reactive $\mathrm{Hg}$ patterns characteristic of aquatic and atmospheric reservoirs. Cinnabar and other ores, rocks, and geothermal deposits characteristically display negative $\delta^{202} \mathrm{Hg}$ signatures ranging as low as $-4 \%$ (e.g., see Hintelmann and Lu 2003, Smith et al. 2005, Smith et al. 2008). Most sediments and coals also have negative $\delta^{202} \mathrm{Hg}$ signatures and negative to slightly positive $\Delta^{199} \mathrm{Hg}$ signatures (Foucher and Hintelmann 2006, and Biswas et al. 2008).

The characteristically negative delta values that are normally found in many terrestrial geological samples support our contention that the higher $\mathrm{Hg}$ levels and lower $\delta^{202} \mathrm{Hg}$ and $\Delta^{199} \mathrm{Hg}$ values in the Norton Sound murres eggs are produced by terrestrial sources of $\mathrm{Hg}$. We believe that erosion in the Yukon River drainage and some of the smaller river systems entering the sound supply newly mobilized Hg to the embayment's water column and sediments. When this terrestrially derived $\mathrm{Hg}$ enters the marine environment, it is in a reactive state and becomes available for fractionation. Norton Sound waters eventually mix with Alaska Coastal Current waters and are advected northward into Bering Strait, where the high $\mathrm{Hg}$ and low fractionation source signatures become diluted and mix with the lower $\mathrm{Hg}$ and more highly fractionated oceanic $\mathrm{Hg}$ reservoirs. 


\section{Persistent Organic Pollutants (POPs)}

\section{General Results}

Organochlorine contaminant levels in the murre and gull eggs were similar to the values we found during our previous study (i.e., NPRB Project 534; see Roseneau et al. 2008). The Kukpuk River delta glaucous gull eggs had the highest contaminant levels, except for pentachlorobenzene and octachlorostyrene, which were higher in the Norton Sound gull eggs (Table 6). BDE 47 in the Kukpuk eggs was an order of a magnitude higher than in the Shishmaref Inlet eggs, the next most contaminated colony. This information suggests that monitoring flame retardants in gull eggs from colonies north of Bering Strait has the potential to provide valuable data on the distribution and temporal changes in this compound in this region of the state.

\section{Regional Comparisons}

Organic contaminant levels in common murre eggs tended to be higher in Norton Sound than in the other sectors of our study area, based on significant differences in $\mathrm{HCB}$, octachlorosytrene, cis-nonachlor, mirex, and BDE 47 values (Fig. 16). In contrast, the Norton Sound gull eggs contained lower levels of organic contaminants than eggs from locations outside this coastal embayment (only 4,4'-DDE, octachlorostyrene, and pentachlorobenzene did not differ significantly). However, these apparent differences may be more complex than the data suggest. $\delta^{15} \mathrm{~N}$ values were significantly higher in the Norton Sound gull and murre eggs than in the eggs from other regions (Fig. 7), which suggest the Norton Sound birds are foraging at higher trophic levels that were exposing them to higher levels of contaminants. $\delta^{13} \mathrm{C}$ values, which normally suggest near-shore versus off-shore foraging strategies, also confuse the picture because they did not differ significantly between the taxa (Fig. 8).

Correlations between stable carbon and nitrogen isotopes and organochlorine contaminants are shown in Table 7. Because we expected contaminant levels to increase with trophic level (as indicated by $\delta^{15} \mathrm{~N}$ ), we were surprised by the significantly negative correlations between pentachlorobenzene in the glaucous gull eggs and heptachlor epoxide in the Bering Sea common murre eggs. However, negative correlations have also been found in thick-billed murre eggs (Vander Pol et al. 2011). Possible explanations for these findings include decoupling between

$\delta^{15} \mathrm{~N}$ and $\delta^{13} \mathrm{C}$ and the contaminant data sets, given the fact that the isotope data represented protein fractions of the diets and the contaminant information was based on lipid fractions. If the birds obtained most of their lipids, and hence most of their contaminant loads, from the same prey types they acquired protein from, then close coupling between $\delta^{15} \mathrm{~N}$ and the contaminants that accumulate at the various trophic levels would be one of the expected outcomes. However, these kinds of couplings are not always present, and if the lipid components of the eggs are primarily derived from body stores obtained from lower trophic level prey, and the protein components are derived from higher trophic level prey (or vice versa), then negative correlations would be the expected outcome. Before we can interpret these data correctly, we need more information on nutrient allocation strategies and their effects on contaminant burdens. 
We conducted a second PCA that combined the $\mathrm{Hg}$ and $\delta^{15} \mathrm{~N}$ and $\delta^{13} \mathrm{C}$ values (Fig. 19). The Bering and Chukchi sea murre and gull eggs still tended to separate, but the gull eggs did not cluster together as well as they did before (Fig. 17). However, lower proportions of $\mathrm{Hg}$ and $\delta^{13} \mathrm{C}$ carbon stable isotopes helped separate the Norton Sound and Bering - Chukchi Sea samples (see the Hg section above).

\section{Species Comparisons}

A previous study reported that common and thick-billed murre eggs from the same colonies contained different organochlorine contaminant levels (Vander Pol et al. 2004). However, the only differences we found in the 2008-2009 samples were in the heptachlor epoxide, pentachlorobenzene, and $\beta-\mathrm{HCH}$ values in the St. George Island eggs (these eggs were collected in different years; thick-bills in 2008 and commons in 2009; see Appendix 2). Pentachlorobenzene levels in the 2008 and 2009 Shaktoolik glaucous gull eggs were also different (MANOVA $\left.\mathrm{F}_{1,7}=18.7, P<0.0034\right)$. 
Table 7. Correlations between major contaminants (on a lipid mass basis) and carbon and nitrogen isotope ratios found in common murre (COMU) and glaucous gull (GLGU) eggs collected in 2008-2009. Significant correlations $(P<0.05)$ are shown in bold.

\begin{tabular}{|c|c|c|c|c|c|c|c|c|c|c|c|c|c|c|}
\hline \multirow[b]{2}{*}{ Pairwise Correlations } & \multicolumn{2}{|c|}{ All Data $n=117$} & \multicolumn{2}{|c|}{ All COMUs n=30 } & \multicolumn{2}{|c|}{ Norton Sound COMUs $n=15$} & \multicolumn{2}{|c|}{ Bering Sea COMUs $n=10$} & \multicolumn{2}{|c|}{ All GLGUs n=52 } & \multicolumn{2}{|c|}{ Norton Sound GLGUs n=37 } & \multicolumn{2}{|c|}{ Bering/Chukchi seas GLGUs $n=15$} \\
\hline & $\mathrm{r}^{2}$ & $P$ & $r^{2}$ & $P$ & $r^{2}$ & $P$ & $r^{2}$ & $P$ & $r^{2}$ & $P$ & $r^{2}$ & $P$ & $r^{2}$ & $P$ \\
\hline$\delta 13 \mathrm{C}-\delta 15 \mathrm{~N}$ & 0.1429 & 0.1243 & -0.2453 & 0.1914 & 0.2751 & 0.321 & 0.8534 & 0.0017 & 0.7254 & $<.0001$ & 0.6972 & $<.0001$ & 0.9265 & $<.0001$ \\
\hline $\mathrm{BDE} 47-\delta 15 \mathrm{~N}$ & 0.0067 & 0.9426 & -0.1362 & 0.473 & 0.1559 & 0.5791 & -0.0076 & 0.9834 & -0.0869 & 0.5402 & 0.0986 & 0.5616 & 0.5721 & 0.0258 \\
\hline$\sum 16 \mathrm{PCBs}-\delta 15 \mathrm{~N}$ & 0.1275 & 0.1708 & -0.0343 & 0.8572 & 0.5143 & 0.0498 & 0.4168 & 0.2308 & -0.1823 & 0.1959 & 0.0774 & 0.6488 & 0.0924 & 0.7433 \\
\hline $4,4^{\prime}-\mathrm{DDE}-\delta 15 \mathrm{~N}$ & -0.0223 & 0.811 & -0.2275 & 0.2267 & 0.2436 & 0.3816 & 0.168 & 0.6426 & -0.2636 & 0.059 & -0.1856 & 0.2714 & 0.0056 & 0.9841 \\
\hline$\beta-\mathrm{HCH}-\delta 15 \mathrm{~N}$ & 0.1269 & 0.1726 & 0.1256 & 0.5084 & 0.1895 & 0.4989 & -0.5563 & 0.0949 & -0.2563 & 0.0666 & 0.0847 & 0.6183 & 0.1394 & 0.6202 \\
\hline HCB- $\delta 15 \mathrm{~N}$ & 0.3613 & $<.0001$ & 0.5683 & 0.0011 & 0.2567 & 0.3557 & 0.1949 & 0.5895 & -0.0458 & 0.7471 & 0.3409 & 0.0389 & 0.0613 & 0.8281 \\
\hline Pentachlorobenzene- $\delta 15 \mathrm{~N}$ & -0.0863 & 0.3549 & -0.1625 & 0.3908 & -0.3016 & 0.2746 & -0.3448 & 0.3292 & -0.3856 & 0.0048 & -0.3923 & 0.0163 & -0.0355 & 0.9002 \\
\hline Cis-nonachlor- $\delta 15 \mathrm{~N}$ & 0.2215 & 0.0164 & 0.2458 & 0.1905 & 0.1851 & 0.509 & -0.4358 & 0.208 & -0.1062 & 0.4537 & 0.0826 & 0.6268 & 0.1579 & 0.5741 \\
\hline Heptachlor epoxide- $\delta 15 \mathrm{~N}$ & 0.164 & 0.0772 & 0.2067 & 0.273 & 0.1328 & 0.6371 & -0.6692 & 0.0343 & -0.218 & 0.1206 & 0.0461 & 0.7863 & 0.019 & 0.9463 \\
\hline Mirex- $\delta 15 \mathrm{~N}$ & 0.1657 & 0.0743 & 0.6145 & 0.0003 & 0.7139 & 0.0028 & -0.189 & 0.601 & -0.1656 & 0.2407 & 0.0609 & 0.7202 & 0.0628 & 0.824 \\
\hline Oxychlordane- $\delta 15 \mathrm{~N}$ & 0.1125 & 0.2273 & 0.2289 & 0.2237 & 0.3032 & 0.272 & 0.2834 & 0.4276 & -0.2076 & 0.1397 & 0.0025 & 0.9882 & 0.2319 & 0.4055 \\
\hline Octachlorosytrene- $\delta 15 \mathrm{~N}$ & 0.3563 & $<.0001$ & 0.5388 & 0.0021 & 0.3441 & 0.2091 & 0.4188 & 0.2284 & 0.1467 & 0.2993 & 0.336 & 0.042 & -0.3664 & 0.1792 \\
\hline BDE $47-\delta 13 \mathrm{C}$ & 0.1007 & 0.2801 & 0.3081 & 0.0977 & 0.3698 & 0.1749 & -0.4266 & 0.2189 & 0.2325 & 0.0973 & -0.1474 & 0.384 & 0.6195 & 0.0138 \\
\hline$\sum 16 \mathrm{PCBs}-\delta 13 \mathrm{C}$ & -0.3228 & 0.0004 & 0.3716 & 0.0432 & 0.5521 & 0.0328 & 0.3508 & 0.3204 & -0.1442 & 0.3077 & -0.228 & 0.1747 & 0.1988 & 0.4775 \\
\hline 4,4'-DDE- $\delta 13 \mathrm{C}$ & -0.3605 & $<.0001$ & 0.4921 & 0.0057 & 0.6039 & 0.0171 & 0.0767 & 0.8332 & -0.3273 & 0.0179 & -0.4111 & 0.0115 & -0.0457 & 0.8716 \\
\hline$\beta-\mathrm{HCH}-\delta 13 \mathrm{C}$ & -0.3451 & 0.0001 & -0.3712 & 0.0435 & 0.0679 & 0.81 & -0.7166 & 0.0197 & -0.1814 & 0.1982 & -0.1892 & 0.2622 & 0.1141 & 0.6856 \\
\hline HCB- $\delta 13 \mathrm{C}$ & -0.2826 & 0.002 & -0.3356 & 0.0698 & 0.1519 & 0.5888 & 0.0526 & 0.8853 & -0.0717 & 0.6134 & 0.0105 & 0.9509 & 0.0675 & 0.8111 \\
\hline Pentachlorobenzene- $\delta 13 \mathrm{C}$ & -0.5481 & $<.0001$ & -0.6208 & 0.0003 & -0.7024 & 0.0035 & -0.6248 & 0.0535 & -0.5766 & $<.0001$ & -0.7294 & $<.0001$ & -0.2261 & 0.4178 \\
\hline Cis-nonachlor- $\delta 13 \mathrm{C}$ & -0.2208 & 0.0168 & 0.0026 & 0.989 & 0.1075 & 0.703 & -0.6072 & 0.0626 & 0.0191 & 0.8932 & -0.0707 & 0.6777 & 0.2172 & 0.4368 \\
\hline Heptachlor epoxide- $\delta 13 \mathrm{C}$ & -0.4381 & $<.0001$ & -0.115 & 0.5452 & 0.1587 & 0.5722 & -0.6459 & 0.0437 & -0.3063 & 0.0272 & -0.369 & 0.0246 & -0.1101 & 0.6961 \\
\hline Mirex- $\delta 13 \mathrm{C}$ & -0.3788 & $<.0001$ & -0.057 & 0.7647 & 0.3446 & 0.2085 & -0.0362 & 0.921 & -0.2159 & 0.1243 & -0.27 & 0.106 & 0.0647 & 0.8187 \\
\hline Oxychlordane- $\delta 13 \mathrm{C}$ & -0.3634 & $<.0001$ & 0.2679 & 0.1524 & 0.4213 & 0.1178 & 0.3717 & 0.2902 & -0.1645 & 0.2438 & -0.425 & 0.0087 & 0.2719 & 0.3269 \\
\hline Octachlorosytrene- $\delta 13 \mathrm{C}$ & -0.0743 & 0.426 & -0.2056 & 0.2758 & 0.2794 & 0.3132 & 0.3454 & 0.3283 & -0.1171 & 0.4085 & 0.018 & 0.9158 & -0.4162 & 0.1228 \\
\hline
\end{tabular}




\section{Temporal Comparisons}

The 2008 St. Lazaria Island common murre eggs showed a slight increase in 4,4'-DDE, $\Sigma_{8} \mathrm{PCBs}$, and HCB levels, compared to previous values (Vander Pol et al. 2004). Because this colony is one of STAMP's annual long-term monitoring sites, we will continue collecting data on the status of these contaminants at this location in upcoming years.

We did not expect to find increased levels of mirex in the 2008 St. George Island thick-billed murre eggs (Fig. 18) because this pesticide is a legacy compound that was banned by the Stockholm Convention on Persistent Organic Pollutants in May 2004 (http://chm.pops.int/). The increase indicates there is a lag in the system that may persist for some time. An increase in this contaminant was also found in the Bogoslof Island 2000-2005 common murre eggs (Vander Pol 2007). Given the combined information from these sampling sites, we believe this pesticide should be monitored in the southern Bering Sea for several more years. Because St. George Island is another one of STAMP's long-term monitoring sites, we will also continue to collect data on this contaminant at this location in future years. It is worth noting that an exemption from the 2004 Stockholm Convention allows China to produce 10-30 tons of this compound annually to help control termites. Also, because Russia and the United States (USA) did not sign the treaty, information is not available from these countries. However, the EPA banned the use of this pesticide in the US in 1978 (http://www.epa.gov/pbt/pubs/mirex.htm). The mirex trend was similar to that for mercury (Fig. 18) collaborating the possible Asian influence to this region of the Southern Bering Sea.

In 1999-2002, organic contaminant levels differed between the St. Lazaria and St. George island murre colonies (see Fig. 6 in Roseneau et al. 2008), but in 2008, these differences were much smaller (Fig.18). This change over the years may explain in part some of the overlap we found between the St. Lawrence Island murre and Stuart Island gull eggs. Although the first PC still tended to separate most of the Bering and Chukchi sea glaucous gull eggs from the murre eggs (Fig. 17), the separation between this region and the Gulf of Alaska was not as distinct as it was during our earlier study when it was complete (see Figs. 8 and 10 in Roseneau et al. 2008; also see Vander Pol 2007). 


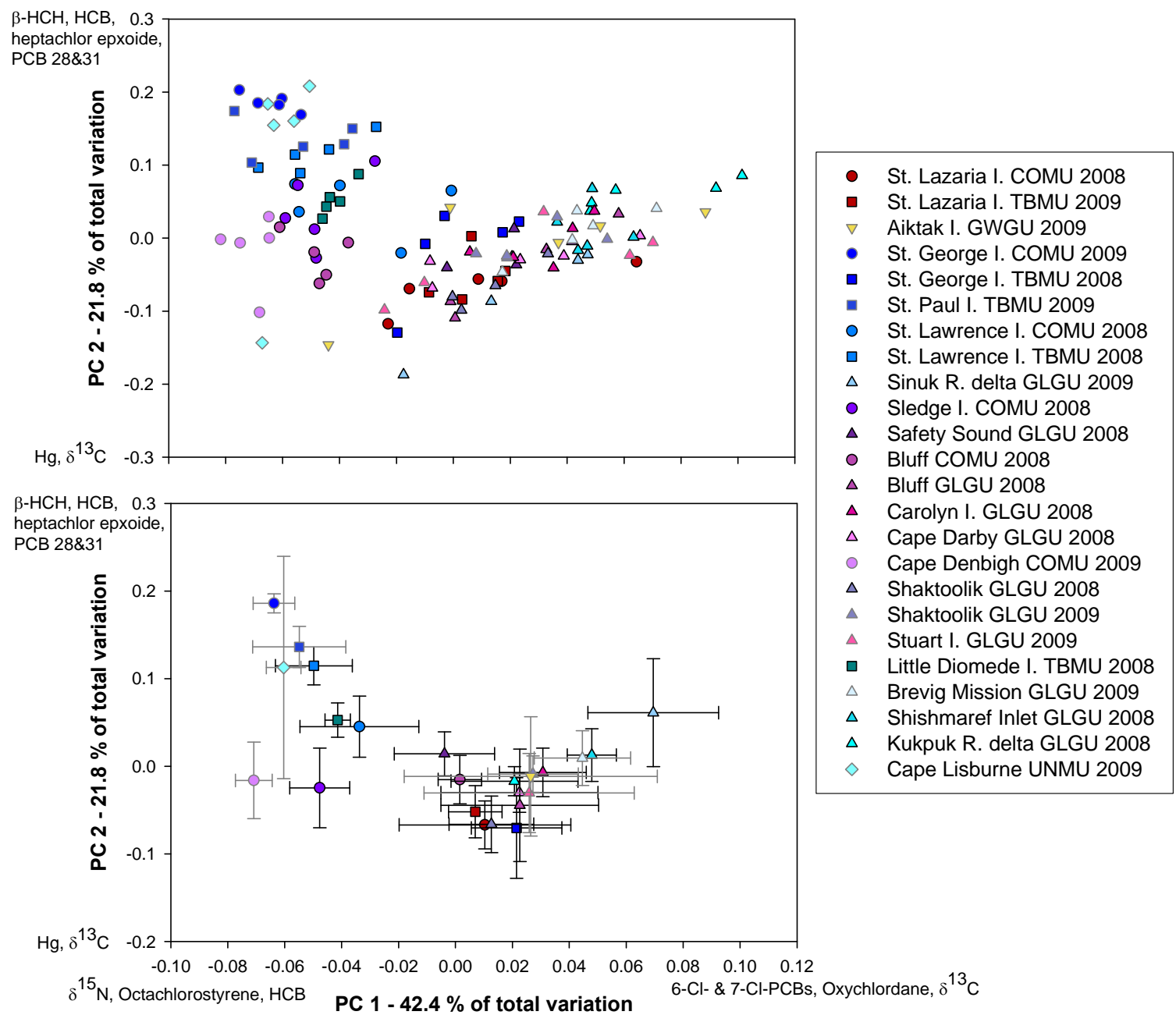

Figure 19. Principal components analyses (means and standard errors) for organic compounds, mercury $(\mathrm{Hg})$, and stable carbon and nitrogen isotopes in common murre (COMU), thick-billed murre (TBMU), glaucous gull (GLGU), and glaucous-winged gull (GWGU) eggs collected at 19 Alaskan colonies in 2008-2009. Compounds contributing to the loadings are shown along the axes (individual samples at top and colony means at bottom). 


\section{Conclusions}

Mercury (Hg) and $\mathrm{Hg}$, Carbon (C), and Nitrogen (N) Isotopes

1. Hg levels in murre eggs were consistently higher in Norton Sound, compared to the Bering and Chukchi seas.

2. Combined $\mathrm{Hg}$ and $\delta^{13} \mathrm{C}$ and $\delta^{15} \mathrm{~N}$ data indicate Norton Sound has a unique mercury regime and that the highest levels of this contaminant are found at its eastern end and along its northern shores between Cape Denbigh and the Sledge Island vicinity.

3. Combined $\delta^{13} \mathrm{C}, \delta^{202} \mathrm{Hg}$, and $\Delta^{199} \mathrm{Hg}$ data provide compelling evidence that terrestrial sources of $\mathrm{Hg}$ are responsible for the elevated levels in Norton Sound and for the declining east-to-west gradient in this coastal embayment.

4. The Yukon River is the largest single point source of $\mathrm{Hg}$ in the Norton Sound region and should be recognized as the major source of this contaminant in western northwestern Alaska's marine environments.

5. Differences between common and thick-billed murre $\mathrm{Hg}$ levels were relatively small in relation to the geographic trends across the study area indicating that either species can be used to determine regional patterns of this contaminant.

6. $\mathrm{Hg}, \delta^{13} \mathrm{C}$, and $\delta^{15} \mathrm{~N}$ isotope patterns did not differ significantly among common and thickbilled murre eggs collected from the same nesting locations.

7. Gull egg Hg levels varied among the Norton Sound colonies, but were not unique to the study area.

8. Overall, gull eggs contained higher levels of $\mathrm{Hg}$ and $\delta^{15} \mathrm{~N}$, and lower levels of $\delta^{13} \mathrm{C}$, compared to murre eggs, indicating that the differences in $\mathrm{Hg}$ contamination between these taxa were probably the result of differences in foraging behavior.

9. Norton Sound murre and gull eggs contained higher levels of $\delta^{15} \mathrm{~N}$, compared to other regions, and this difference may have been caused by the Norton Sound birds feeding at higher trophic levels, or by an ecosystem-wide higher $\delta^{15} \mathrm{~N}$ baseline level.

10. Norton Sound murre eggs had significantly lower $\delta^{13} \mathrm{C}$ levels relative to the northern Bering and Chukchi seas, indicating that the carbon sources in this embayment are probably terrestrial in origin.

11. Norton Sound murre eggs had significantly lower $\delta^{202} \mathrm{Hg}$ and $\Delta^{199} \mathrm{Hg}$ levels relative to the northern Bering and Chukchi seas, indicating lower levels of mass dependent and mass independent fractionation that may have resulted from:

a. Suppression of fractionation processes because of increased turbidity; or 
b. Inputs of terrestrially derived $\mathrm{Hg}$ from geological sources, which are typically characterized by low or negative fractionation; or

c. Both of these factors.

12. Sea-ice cover alone cannot explain the lower MIF found in the Norton Sound and northern Bering Sea murre eggs.

13. Because trophic levels and habitat/prey selections appear to influence $\mathrm{Hg}$ patterns in taxa, $\delta^{15} \mathrm{~N}$ and $\delta^{13} \mathrm{C}$ analyses should be included in long-term contaminants monitoring programs.

\section{$\underline{\text { Persistent Organic Pollutants (POPs) }}$}

1. The geographic organic contaminant patterns found in the Bering Sea and Gulf of Alaska during NPRB Project 534 are still present, but they may be weakening.

2. There are clear differences in organic contaminant levels between murre and gull eggs.

3. Organic contaminant levels appear to be stable or decreasing, with the exception of mirex at St. George Island, where it has increased in thick-billed murre eggs since 2002.

4. The increase in mirex at St. George Island, coupled with a similar increase previously documented in Bogoslof Island common murre eggs, indicates this pesticide should be monitored in the southern Bering Sea for several more years.

5. The variable POP and $\mathrm{Hg}$ levels found in the gull eggs clearly reflect differences in prey availability among sampling locations and the opportunistic feeding habits of these birds indicating they are not good candidates for contaminants monitoring programs.

6. Monitoring POPs in Bering and Chukchi seas and Gulf of Alaska murre eggs can help identify a variety of physical and chemical factors that may be affecting these environments in different ways.

\section{Recommendations}

1. There is a need to clarify what effects the Yukon River sediments and suspended particulates entering Norton Sound have on the embayment's Hg isotope signatures.

2. There is a need to measure $\delta^{15} \mathrm{~N}$ and $\delta^{13} \mathrm{C}$ isotope levels in Norton Sound zooplankton so that quantitative corrections can be made across regions and $\mathrm{Hg}$ loading can be compared among sampling sites more accurately. 


\section{Literature Cited}

Aagaard, K. and E.C. Carmack. 1989. The role of sea ice and other fresh water in the Arctic circulation. Journal of Geophysical Research 94:14485-14498.

Ahmasuk, A. and E. Trigg. 2007. Bering Strait region local and traditional knowledge pilot project; a comprehensive subsistence use study of the Bering Strait region. North Pacific Research Board Project 643 Final Report, 303 pp.

Ainley, D.G., D.N. Nettleship, H.R. Carter, and A.E. Storey. 2002. The Birds of North America, Academy of Natural Sciences and American Ornithologists' Union.

AMAP. 1998. Scientific Experts Workshop, Girdwood, Alaska, April 1998.

AMAP. 1999. Heavy metals in the Arctic Workshop. Anchorage, Alaska, September 1999. (AMAP report 99:8).

Atlas, R.M., M.I. Venkatesan, I.R. Kaplan, R.A. Feely, R.P. Griffiths, and R.Y. Morita. 1983. Distribution of hydrocarbons and microbial populations related to sedimentation processes in lower Cook Inlet and Norton Sound, Alaska. Arctic 36:251-261.

Atwell, L., K.A. Hobson and H.E. Welch. 1998. Biomagnification and bioaccumulation of mercury in an arctic marine food web: insights from stable nitrogen isotope analysis. Canadian Journal of Fisheries and Aquatic Sciences 55:1114-1121.

Barrett, R.T., M. Asheim, and V. Bakken. 1997. Ecological relationships between two sympatric congeneric species, common murres and thick-billed murres, Uria aalge and U. lomvia. Canadian Journal of Zoology 75:618-631.

Bergquist, B.A. and J.D. Blum. 2007. Mass-dependent and -independent fractionation of $\mathrm{Hg}$ isotopes by photoreduction in aquatic systems. Science 318:417-420.

Biswas, A., J.D. Blum, B.A. Bergquist, G.J. Keeler, and Z. Xie. 2008. Natural mercury isotope variation in coal deposits and organic soils. Environmental Science and Technology 42:83038309 .

Campbell, L.M., R.J. Norstrom, K.A. Hobson, D.C.G. Muir, S. Backus, and A.T. Fisk. 2005. Mercury and other trace elements in a pelagic Arctic marine food web (Northwater Polynya, Baffin Bay). Science of the Total Environment 351-352:247-263.

Carignan, J., N. Estrade, J.E. Sonke, and O.F.X. Donard. 2009. Odd isotope deficits in atmospheric Hg measured in lichens. Environmental Science and Technology 43:5660-5664. 
Chasar, L.C., B.C. Scudder, A.R. Stewart, A.H. Bell, and G.R. Aiken. 2009. Mercury cycling in stream ecosystems. 3. Trophic dynamics and methylmercury bioaccumulation. Environmental Science and Technology 43(8):2733-2739.

Christopher, S.J., S.E. Long, M.S. Rearick, and J.D. Fassett. 2001. Development of isotope dilution cold vapor inductively coupled plasma mass spectrometry and its application to the certification of mercury in NIST standard reference materials. Analytical Chemistry 73(10):2190-2199.

Chumchal, M.M. and K.D. Hambright. 2009. Ecological factors regulating mercury contamination of fish from Caddo Lake, Texas, USA. Environmental Toxicology and Chemistry 28(5):962-972.

Coachman, L.K., Aagaard, K, and Tripp, R.B. 1975. Bering Strait, the regional physical oceanography. University of Washington Press, Seattle, Washington. 172 pp.

Coyle, K.O., G.L. Hunt, M.B. Decker, and T.J. Weingartner. 1992. Murre foraging, epibenthic sound scattering and tidal advection over a shoal near St. George Island, Bering Sea. Marine Ecology Progress Series 83:1-14.

Davis, W.C., S.S. Vander Pol, R.S. Pugh, R.D. Day, and P.R. Becker. 2004. An accurate and sensitive method for the determination of methylmercury in biological specimens using GC-ICPMS with solid-phase microextraction. Journal of Analytical Atomic Spectrometry 19:1546-1551.

Day, R.D., S.S. Vander Pol, S.J. Christopher, W.C. Davis, R.S. Pugh, K.S. Simac, D.G. Roseneau, and P.R. Becker. 2006. Murre eggs (Uria aalge and Uria lomvia) as indicators of mercury contamination in the Alaskan marine environment. Environmental Science and Technology 40 (3): 659-665.

Day, R.D., D.G. Roseneau, K.A. Hobson, O.F.X. Donard, S.S. Vander Pol, R.S. Pugh, A. Moors, and P.R. Becker. In prep. Regional, temporal, and species patterns of mercury in Alaskan seabird eggs: mercury sources and cycling or food web effects? (to be submitted to Environmental Pollution).

Dietz, R., P.M. Outridge, and K.A. Hobson. 2009. Anthropogenic contributions to mercury levels in present-day arctic animals - a review. Science of the Total Environment 407(24):61206131.

Dragoo, D.E. 1991. Food habits and productivity of kittiwakes and murres at St. George Island, Alaska. University of Alaska - Fairbanks Master's Thesis.104 pp.

Dunton, K.H., T. Weingartner and E.C. Carmack. 2006. The nearshore western Beaufort Sea ecosystem: circulation and importance of terrestrial carbon in arctic coastal food webs. Progress in Oceanography 71:362-3778. 
Elphick, C.S. and G.L. Hunt, Jr. 1993. Variations in the distribution of marine birds in water mass in the northern Bering Sea. Condor 95:33-44.

Estrade, N., J. Carignan and O.F.X. Donard. 2011. Tracing and Quantifying Anthropogenic Mercury Sources in Soils of Northern France Using Isotopic Signatures. Environmental Science and Technology 45:1235-1242.

Fernandes, M.B. and M.-A. Sicre. 2000. The importance of terrestrial organic carbon inputs on Kara Sea shelves as revealed by n-alkanes, OC and d13C values. Organic Geochemistry 31:363374.

Feng, X., D. Foucher, H. Hintelmann, H. Yan, T. He, T. and G. Qiu. 2010. Tracing Mercury Contamination Sources in Sediments Using Mercury Isotope Compositions. Environmental Science and Technology 44:3363-3368.

Fitzgerald, W.F., C.H. Lamborg, and C.R. Hammerschmidt. 2007. Marine Biogeochemical Cycling of Mercury. Chemical Reviews 107:641-662.

Foucher, D. and H. Hintelmann. 2006. High-precision measurement of mercury isotope ratios in sediments using cold-vapor generation multi-collector inductively coupled plasma mass spectrometry. Analytical and Bioanalytical Chemistry 384:1470-1478.

Foucher, D., N. Ogrinc and Hintelmann H. 2009. Tracing Mercury Contamination from the Idrija Mining Region (Slovenia) to the Gulf of Trieste Using Hg Isotope Ratio Measurements. Environmental Science and Technology 43:33-39.

Gantner, N., H. Hintelmann, W. Zheng and D.C.G. Muir. 2009. Variations in Stable Isotope Fractionation of $\mathrm{Hg}$ in Food Webs of Arctic Lakes. Environmental Science and Technology 43:9148-9154.

Gaston, A.J. and I.L. Jones. 1998. The Auks. In Bird Families of the World. New York, Oxford University Press.

Gehrke, G.E., J.D. Blum and M. Marvin-DiPasquale. 2011. Sources of mercury to San Francisco Bay surface sediment as revealed by mercury stable isotopes. Geochimica et Cosmochimica Acta 75:691-705.

Grebmeier, J.M., J.E. Overland, S.E. Moore, E.V. Farley, E.C. Carmack, L.W. Cooper, K.E. Frey, J.H. Helle, F.A. McLaughlin, and S.L. McNutt. 2006. A major ecosystem shift in the northern Bering Sea. Science 311:1446-1464.

Guo, L. and R.W. Macdonald. 2006. Sources and transport of terrigenous organic matter in the upper Yukon River: evidence from isotope (13C, 14C and 15N) composition of dissolved, colloidal and particulate phases. Global Biogeochemical Cycles 20. 
Guo, L., T. Tanaka, D. Wang, N. Tanaka, and A. Murata. 2004. Distributions, speciation and stable isotope composition of organic matter in the southeastern Bering Sea. Marine Chemistry 91:211-226.

Hintelmann, H. and S. Lu 2003. High precision isotope ratio measurements of mercury isotopes in cinnabar ores using multi-collector inductively coupled plasma mass spectrometry. Analyst 128:635-639.

Harrison, E.S. 1905. Nome and Seward Peninsula. The Metropolitan Press, Seattle, Washington. $392 \mathrm{pp}$.

Hobson, K.A., J.F. Piatt, and J. Pitocchelli. 1994. Using stable isotopes to determine seabird trophic relationships. Journal of Animal Ecology 63:786-798.

Hobson, K.A., L.I. Wassenar, B. Mila, I. Lovette, C. Dingle, and T.B. Smith. 2002. Stable isotopes as indicators of altitudinal distributions and movements in an Ecuadorean hummingbird community. Oecologia 136:302-308.

Jaegar, I., H. Hop and G.W. Gabrielson. 2009. Biomagnification of mercury in selected species from an Arctic marine food web in Svalbard. Science of the Total Environment 407:4744-4751.

Jarman, W.M., K.A. Hobson, W.J. Sydeman, C.E. Bacon, and E.B. McLaren. 1996. Influence of trophic position and feeding location on contaminant levels in the Gulf of the Farallones food web revealed by stable isotope analysis. Environmental Science and Technology 30(2):654-660.

Kritee, K., J.D. Blum, M.W. Johnson, B.A. Bergquist, and T. Barkay. 2007. Mercury stable isotope fractionation during reduction of $\mathrm{Hg}(\mathrm{II})$ to $\mathrm{Hg}(0)$ by mercury resistant microorganisms. Environmental Science and Technology 41:1889-1895.

Laffont, L., J.E. Sonke, L. Maurice, H. Hintelmann, M. Pouilly, Y.S. Bacarreza, T. Perez, and P. Behra. 2009. Anomalous mercury isotopic compositions of fish and human hair in the Bolivian Amazon. Environmental Science and Technology 43:8985-8990.

Liu, J., X. Feng, R. Yin, W. Zhu and Z. Li. 2011. Mercury distributions and mercury isotope signatures in sediments of Dongjiang, the Pearl River Delta, China. Chemical Geology 287:8189.

Mundy, P.R., D.M. Allen, J.L. Bolt, N.A. Bond, S. Dressel, E.V. Farley Jr., D.H. Hanselman, J. Heifetz, R.R. Hopcroft, M.A. Janout, C. Ladd, R.C. Lam, P.A. Livingston, C.R. Lunsford, J.T. Mathis, F.J. Mueter, C.N.

Murphy, E.C., A.M. Springer, and D.G. Roseneau. 1986. Population status of Uria aalge at a colony in western Alaska: results and simulations. Ibis 128: 348-363.

Nelson, C.H., D.E. Pierce, K.W. Leong, and F.F.H. Wang. 1975. Mercury distribution in ancient and modern sediment of northeastern Bering Sea. Marine Geology 18:91-104. 
Perrot, V., V.N. Epov, M.V. Pastukhov, V.I. Grebenshchikova, C. Zouiten, J.E. Sonke, S. Husted, O.F.X. Donard, and D. Amouroux. 2010. Tracing sources and bioaccumulation of mercury in fish of Lake Baikal - Angara River using $\mathrm{Hg}$ isotopic composition. Environmental Science and Technology 44:8030-8037.

Point, D., J.E. Sonke, R.D. Day, D.G. Roseneau, K.A. Hobson, S.S. Vander Pol, A.J. Moors, R.S. Pugh, O.F.X. Donard, and P.R. Becker. 2011. Methylmercury photodegradation influenced by sea-ice cover in arctic marine ecosystems. Nature Geosciences 4:188-194. (Publ. online 01/16/2011; DOI: 10.1038/NGE01049).

Reed, R.K., 1968. Transport of the Alaskan Stream. Nature 220:681-682 (doi:10.1038/220681a0).

Ridley, W.I. and S.J. Stetson. 2006. A review of isotopic composition as an indicator of the natural and anthropogenic behavior of mercury. Applied Geochemistry 21:1889-1899.

Rooper, N. Sarkar, S.A.K. Shotwell, M.V. Sturdevant, A.C. Thomas, T.J. Weingartner, and D. Woody. 2010. Status and trends of the Alaska Current Region, 2003-2008. Pp. 142-195 in S.M. McKinnell and M.J. Dagg (Eds.), Marine ecosystems of the North Pacific Ocean, 2003-2008. PICES Special Publication 4, 393 pp.

Roseneau, D.G., M.F. Chance, P.F. Chance, and G.V. Byrd. 2000. Monitoring seabird populations in areas of oil and gas development on the Alaskan continental shelf: Cape Lisburne and Cape Thompson seabird studies, 1995-1997. Final rept. by the Alaska Maritime National Wildlife Refuge, Homer, Alaska to the U.S. Geological Survey Biological Resources Division, Western Regional Office, Seattle, Washington (USGS Study USGS/BRD/CR-1999-0002 and OCS Study 99-0011), 147 pp.

Roseneau, D.G., P.R. Becker, S.S Vander Pol, R.D. Day, D. Point, K.S. Simac, A.J. Moors, M.B. Ellisor, R.S. Pugh, and G.S. York. 2008. Expanding the Seabird Tissue Archival and Monitoring Project (STAMP) in the North Pacific: Geographic patterns in contaminant residues in seabird eggs used in rural subsistence diets. North Pacific Research Board Project 534 Final Report, 145 pp.

Rust, L.B, R.S. Pugh, A.J. Moors, P.R. Becker, S.S. Vander Pol, and D.G. Roseneau. 2010. Seabird Tissue Archival and Monitoring Project: Protocol for collecting and banking seabird eggs. NISTIR 7678, Gaithersburg, MD. 50 pp.

Schell, D.M., B.A. Barnett, and K.A. Vinette. 1998. Carbon and nitrogen isotope ratios in zooplankton of the Bering, Chukchi and Beaufort seas. Marine Ecology Progress Series 162:1123.

Schuster, P.F., R. Streigel, M. Dornblaser, G. Aiken, D. Krabbenhoft, J. Dewild, and K. Butler. 2010. Mercury export from the Yukon River Basin: a unique opportunity to assess global 
atmospheric sources at large scales and potential future responses to climate change. American Geophysical Union Fall Meeting, San Francisco, CA.

Senn, D.B., E.J. Chesney, J.D. Blum, M.S. Bank, A. Maage, and J.P. Shine. 2010. Stable isotope (N, C, Hg) study of methylmercury sources and trophic transfer in the Northern Gulf of Mexico. Environmental Science and Technology 44:1630-1637.

Smith, C.N., S.E. Kesler, J.D. Blum, and J.J. Rytuba. 2008. Isotope geochemistry of mercury in source rocks, mineral deposits and spring deposits of the California Coast Ranges, USA. Earth and Planetary Science Letters 269:399-407.

Smith, C.N., B. Klaue, S.E. Kesler, and J.D. Blum. 2005. Mercury isotope fractionation in fossil hydrothermal systems. Geology 33:825-828.

Springer, A.M. and D.G. Roseneau. 1985. Copepod-based food webs: auklets and oceanography in the Bering Sea. Marine Ecol. Prog. Ser. 21: 229-237.

Springer, A.M., D.G. Roseneau, E.C. Murphy, and M.I. Springer. 1984. Environmental controls of marine food webs: food habits of seabirds in the Eastern Chukchi Sea. Canadian Journal of Fisheries and Aquatic Sciences 41:1202-1215.

Springer, A.M., D.G. Roseneau, D.S. Lloyd, C.P. McRoy, and E.C. Murphy .1986. Seabird responses to fluctuating prey availability in the eastern Bering Sea. Marine Ecology Progress Series 32:1-12.

Springer, A.M., E.C. Murphy, D.G. Roseneau, C.P. McRoy, and B.A. Cooper. 1987. The paradox of pelagic food webs in the northern Bering Sea - I. Seabird food habits. Continental Shelf Research 7:895-911.

Sonke, J.E., 2011. A global model of mass independent mercury stable isotope fractionation. Geochimica et Cosmochimica Acta 75:4577-4590.

Sowls, A.L., S.A. Hatch, and C.J. Lensink. 1978. Catalog of Alaskan seabird colonies. U.S. Fish Wildl. Serv., Biol. Serv. Prog. FWS/OBS 78/78, Anchorage, AK. 153 pp.

Swartz, L.G. 1966. Sea-cliff birds. Pp. 611-678 in N.J. Wilimovsky and J.N. Wolfe (eds.), Environment of the Cape Thompson region, Alaska. U.S. Atomic Energy Commission, Div. of Tech. Information Extension, Oak Ridge, Tennessee. 1,250pp. [Available as two paperback volumes (Books 1 and 2) from the Natl. Tech. Information Serv., Dept. of Comm., Springfield, Virginia 22161.]

Vander Pol, S.S., Becker, P.R., Kucklick, J.R., Pugh, R.S., Roseneau, D.G., and Simac, K.S. 2004. Persistent organic pollutants in Alaskan murre (Uria spp.) eggs: geographical, species, and temporal comparisons. Environmental Science and Technology 38:1305-1312. 
Vander Pol, S.S. 2005. Preparation of toxaphene congener calibration solutions. NIST Report of Activities (ROA) 839.02-07-305, Gaithersburg, MD.

Vander Pol, S.S. 2007. Determination of polybrominated diphenyl ethers (PBDEs), polychlorinated biphenyls (PCBs), and organochlorine pesticides in common murre (Uria aalge) eggs collected in 2003-2005 for the Seabird Tissue Archival and Monitoring Project (STAMP). NIST Report of Activities (ROA) 839.02-07-305, Gaithersburg, MD.

Vander Pol, S.S., M.B. Ellisor, R.S. Pugh, P.R. Becker, D.L. Poster, M.M. Schantz, S.D. Leigh, B.J. Wakeford, D.G. Roseneau, and K.S. Simac. 2007. Development of a murre (Uria spp.) egg control material. Analytical and Bioanalytical Chemistry 387, 2357-2363.

Vander Pol, S.S., P.R. Becker, M.B. Ellisor, A.J. Moors, R.S. Pugh, and D.G. Roseneau. 2009. Monitoring organic contaminants in eggs of glaucous and glaucous-winged gulls (Larus hyperboreus and Larus glaucescens) from Alaska. Environmental Pollution 157: 755-762.

Vander Pol, S.S., K.A. Hobson, P.R. Becker, R.D. Day, M.B. Ellisor, R.S. Pugh, and D.G. Roseneau. 2011. Geographic differences in organic contaminants and stable isotopes $\left(\delta^{13} \mathrm{C}, \delta^{15} \mathrm{~N}\right)$ in thick-billed murre (Uria lomvia) eggs from Alaska. Journal of Environmental Monitoring (DOI: 10.1039/c0em00347f).

Venkatesan, M.I. and I.R. Kaplan. 1982. Distribution and transport of hydrocarbons in surface sediments of the Alaskan Outer Continental Shelf. Geochimica et Cosmochimica Acta 46:21352149 .

WenFang, S., X. Feng, G. Zhang, L. Ming, R. Yin, Z. Zhao and J. Wang. 2011. High-precision measurement of mercury isotope ratios of atmospheric deposition over the past 150 years recorded in a peat core take from Hongyuan, Sichuan Province, China. Chinese Science Bulletin 56:877-882.

Woodgate, R.A., K. Aagaard, and T. Weingartner. 1995. Monthly temperature, salinity and transport variability of the Bering Strait throughflow. Journal of Geophysical Research 100:18,443-18.457.

Yin, R., X. Feng and W. Shi. 2010. Application of the stable-isotope system to the study of sources and fate of $\mathrm{Hg}$ in the environment: A review. Applied Geochemistry 25:1467-1477.

Yang, L. and R.E. Sturgeon. 2009. Isotopic fractionation of mercury induced by reduction and ethylation. Analytical and Bioanalytical Chemistry 393:377-385.

Zhou, X., N.B. Chang and S. Li. 2007. Detection of coastal region sea ice decay from orthorectified RADARSTAT-1 ScanSAR imagery: A case study of Bering Strait and Norton Sound, Alaska. Journal of Environmental Informatics 10(1):37-46. 
Zou, L., M.-Y. Sun and L. Guo. 2006. Temporal variations of organic carbon inputs into the upper Yukon River: Evidence from fatty acids and their stable carbon isotopic compositions in dissolved, colloidal and particulate phases. Organic Geochemistry 37:944-956. 
Appendix 1. A typical egg collecting kit used to mail supplies and safely transport murre and gull eggs for this study.
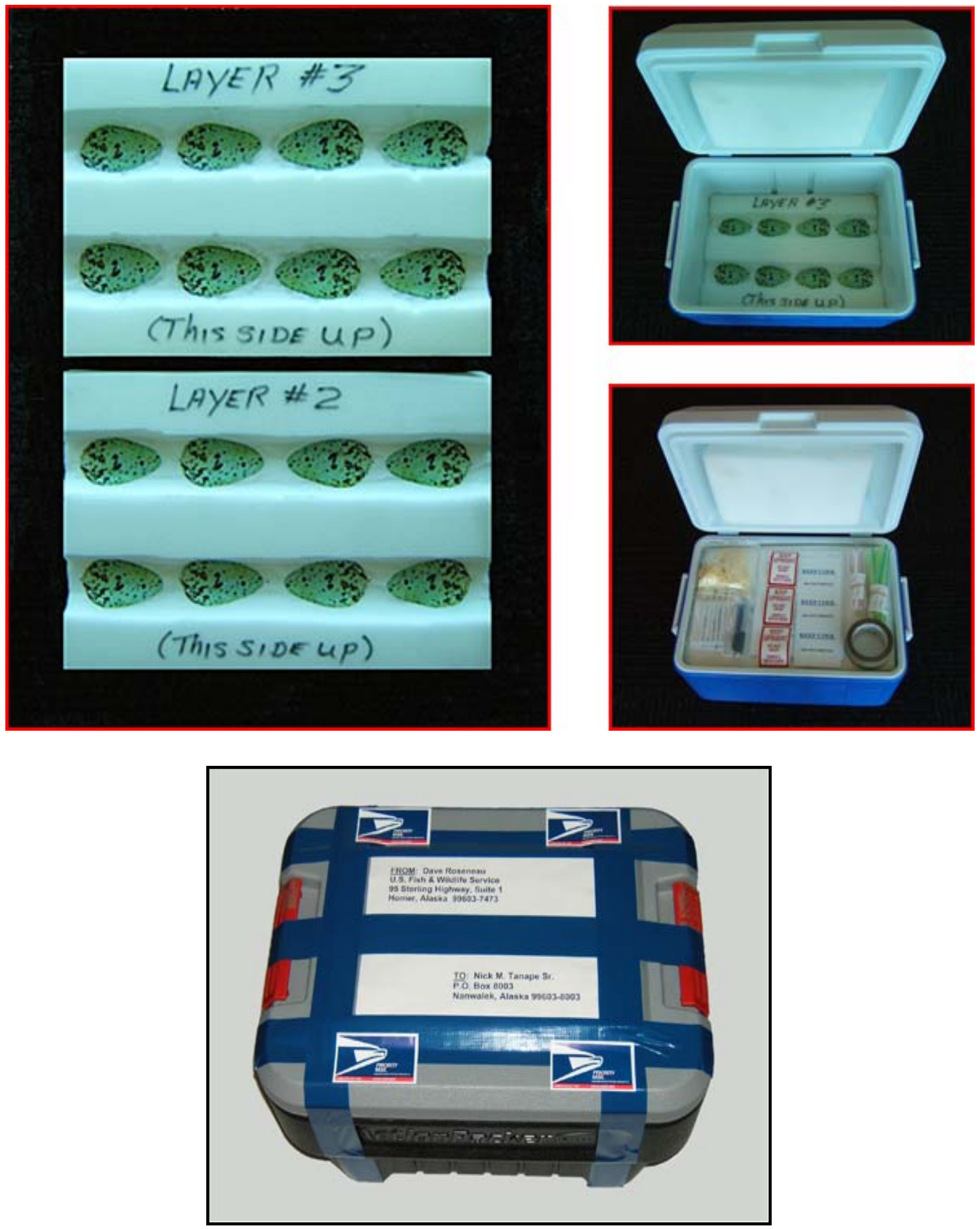
Appendix 2. Murre and gull egg samples banked in the Marine ESB in Charleston, South Carolina, that were used for polybrominated diphenyl ether (PBDE), polychlorinated biphenyl (PCB), organochlorine pesticide, total mercury (Hg), and carbon and nitrogen stable isotope analyses.

\begin{tabular}{|c|c|c|c|c|c|c|c|c|c|c|c|}
\hline \multicolumn{3}{|c|}{ ID } & \multirow[b]{2}{*}{ Species } & \multirow{2}{*}{$\begin{array}{l}\text { Colony } \\
\text { Location }\end{array}$} & \multirow{2}{*}{$\begin{array}{c}\text { Collection } \\
\text { Date }\end{array}$} & \multirow{2}{*}{\multicolumn{3}{|c|}{$\begin{array}{c}\text { Mass (g) } \\
\end{array}$}} & \multirow[b]{2}{*}{$\Pi$ Length $(\mathrm{cm})$} & \multirow[b]{2}{*}{ Width $(\mathrm{cm})$} & \multirow[b]{2}{*}{ Notes } \\
\hline Number & $\frac{\text { IV }}{\text { Storage }}$ & Field & & & & $\overline{\text { Whole Egs }}$ & & Eggshell & & & \\
\hline 1234 & ST09E1234C & STLA03COMU08 & Uria aalge & SE Gulf of Alaska, St. Lazaria I. & 7/9/2008 & 119.2 & 99.6 & 18.8 & not measured & not measured & \\
\hline 1235 & ST09E1235C & STLA04COMU08 & Uria aalge & SE Gulf of Alaska, St. Lazaria I. & $7 / 9 / 2008$ & 116.2 & 96.6 & 19.4 & not measured & not measured & \\
\hline 1236 & ST09E1236C & STLA05COMU08 & Uria aalge & SE Gulf of Alaska, St. Lazaria I. & $7 / 9 / 2008$ & 124.0 & 101.6 & 18.2 & not measured & not measured & \\
\hline 1238 & ST09E1238C & STLA07COMU08 & Uria aalge & SE Gulf of Alaska, St. Lazaria I. & $7 / 9 / 2008$ & 116.2 & 95.9 & 19.9 & not measured & not measured & \\
\hline 1240 & ST09E1240C & STLA09COMU08 & Uria aalge & SE Gulf of Alaska, St. Lazaria I. & $7 / 9 / 2008$ & 106.5 & 88.4 & 17.9 & not measured & not measured & \\
\hline 1242 & ST09E1242C & STLA01TBMU08 & Uria lomvia & SE Gulf of Alaska, St. Lazaria I. & $7 / 9 / 2008$ & 99.6 & 82.1 & 16.9 & not measured & not measured & \\
\hline 1243 & ST09E1243C & STLA02TBMU08 & Uria lomvia & SE Gulf of Alaska, St. Lazaria I. & $7 / 9 / 2008$ & 111.6 & 92.7 & 18.6 & not measured & not measured & \\
\hline 1244 & ST09E1244C & STLA03TBMU08 & Uria lomvia & SE Gulf of Alaska, St. Lazaria I. & $7 / 9 / 2008$ & 113.7 & 96.2 & 16.8 & not measured & not measured & \\
\hline 1245 & ST09E1245C & STLA04TBMU08 & Uria lomvia & SE Gulf of Alaska, St. Lazaria I. & $7 / 9 / 2008$ & 92.4 & 74.9 & 16.9 & not measured & not measured & \\
\hline 1246 & ST09E1246C & STLA05TBMU08 & Uria lomvia & SE Gulf of Alaska, St. Lazaria I. & $7 / 9 / 2008$ & 94.4 & 80.3 & 13.7 & not measured & not measured & \\
\hline 1250 & ST09E1250C & DIOM04TBMU08 & Uria lomvia & Bering Strait, Little Diomede I. & $7 / 2 / 2008$ & 129.8 & 104.1 & 21.3 & not measured & not measured & \\
\hline 1256 & ST09E1256C & DIOM10TBMU08 & Uria lomvia & Bering Strait, Little Diomede I. & $7 / 2 / 2008$ & 118.5 & 98.5 & 19.7 & not measured & not measured & \\
\hline 1257 & ST09E1257C & DIOM11TBMU08 & Uria lomvia & Bering Strait, Little Diomede I. & $7 / 2 / 2008$ & 111.5 & 90.3 & 20.8 & not measured & not measured & \\
\hline 1260 & ST09E1260C & DIOM14TBMU08 & Uria lomvia & Bering Strait, Little Diomede I. & $7 / 2 / 2008$ & 125.0 & 101.9 & 22.0 & not measured & not measured & \\
\hline 1261 & ST09E1261C & DIOM15TBMU08 & Uria lomvia & Bering Strait, Little Diomede I. & $7 / 2 / 2008$ & 120.2 & 98.3 & 21.5 & not measured & not measured & \\
\hline 1265 & ST09E1265C & STLW04COMU08 & Uria aalge & N Bering Sea, St. Lawrence I. & $6 / 29 / 2008$ & 126.5 & 104.9 & 17.2 & not measured & not measured & \\
\hline 1266 & ST09E1266C & STLW05COMU08 & Uria aalge & N Bering Sea, St. Lawrence I. & $6 / 29 / 2008$ & 106.0 & 84.3 & 21.1 & not measured & not measured & \\
\hline 1267 & ST09E1267C & STLW06COMU08 & Uria aalge & N Bering Sea, St. Lawrence I. & $6 / 29 / 2008$ & 129.5 & 99.5 & 29.0 & not measured & not measured & \\
\hline 1268 & ST09E1268C & STLW07COMU08 & Uria aalge & N Bering Sea, St. Lawrence I. & $6 / 29 / 2008$ & 122.0 & 100.9 & 20.6 & not measured & not measured & \\
\hline 1275 & ST09E1275C & STLW14COMU08 & Uria aalge & N Bering Sea, St. Lawrence I. & $6 / 29 / 2008$ & 137.0 & 107.2 & 29.1 & not measured & not measured & \\
\hline 1278 & ST09E1278C & STLW02TBMU08 & Uria lomvia & N Bering Sea, St. Lawrence I. & $6 / 29 / 2008$ & 130.3 & 108.9 & 21.2 & not measured & not measured & \\
\hline 1279 & ST09E1279C & STLW03TBMU08 & Uria lomvia & N Bering Sea, St. Lawrence I. & $6 / 29 / 2008$ & 117.2 & 98.1 & 18.5 & not measured & not measured & \\
\hline 1281 & ST09E1281C & STLW05TBMU08 & Uria lomvia & N Bering Sea, St. Lawrence I. & $6 / 29 / 2008$ & 127.1 & 104.9 & 22.0 & not measured & not measured & \\
\hline 1284 & ST09E1284C & STLW08TBMU08 & Uria lomvia & N Bering Sea, St. Lawrence I. & $6 / 29 / 2008$ & 123.6 & 100.1 & 19.8 & not measured & not measured & \\
\hline 1287 & ST09E1287C & STLW11TBMU08 & Uria lomvia & N Bering Sea, St. Lawrence I. & $6 / 29 / 2008$ & 123.8 & 104.3 & 19.0 & not measured & not measured & \\
\hline 1292 & ST09E1292C & SLED01COMU08 & Uria aalge & Norton Sound, Sledge I. & $6 / 21 / 2008$ & 121.7 & 94.0 & 24.1 & 7.92 & 4.75 & \\
\hline 1295 & ST09E1295C & SLED05COMU08 & Uria aalge & Norton Sound, Sledge I. & $6 / 21 / 2008$ & 126.3 & 100.9 & 22.8 & 7.80 & 4.18 & \\
\hline 1301 & ST09E1301C & SLED11COMU08 & Uria aalge & Norton Sound, Sledge I. & $6 / 21 / 2008$ & 123.3 & 103.1 & 18.1 & 7.62 & 4.26 & \\
\hline 1303 & ST09E1303C & SLED13COMU08 & Uria aalge & Norton Sound, Sledge I. & $6 / 21 / 2008$ & 113.0 & 92.6 & 17.9 & 7.17 & 4.13 & \\
\hline 1305 & ST09E1305C & SLED15COMU08 & Uria aalge & Norton Sound, Sledge I. & $6 / 21 / 2008$ & 121.2 & 100.6 & 19.3 & 7.28 & 4.30 & \\
\hline 1307 & ST09E1307C & BLUF02COMU08 & Uria aalge & Norton Sound, Bluff & $6 / 20 / 2008$ & 116.2 & 97.8 & 18.1 & not measured & not measured & \\
\hline 1309 & ST09E1309C & BLUF04COMU08 & Uria aalge & Norton Sound, Bluff & 6/20/2008 & 132.0 & 110.1 & 21.5 & not measured & not measured & \\
\hline 1314 & ST09E1314C & BLUF09COMU08 & Uria aalge & Norton Sound, Bluff & $6 / 20 / 2008$ & 122.1 & 101.2 & 19.8 & not measured & not measured & \\
\hline 1319 & ST09E1319C & BLUF14COMU08 & Uria aalge & Norton Sound, Bluff & 6/20/2008 & 117.8 & 97.8 & 19.9 & not measured & not measured & \\
\hline 1320 & ST09E1320C & BLUF15COMU08 & Uria aalge & Norton Sound, Bluff & 6/20/2008 & 121.3 & 100.1 & 20.8 & not measured & not measured & \\
\hline 1321 & ST09E1321C & STGE01TBMU08 & Uria lomvia & SE Bering Sea, St. George I. & $7 / 11 / 2008$ & 90.4 & 73.4 & 12.1 & 6.99 & 4.31 & Egg contained a developing embryo about $2.5 \mathrm{~cm}$ in diameter. \\
\hline 1331 & ST09E1331C & STGE11TBMU08 & Uria lomvia & SE Bering Sea, St. George I. & $7 / 11 / 2008$ & 106.0 & 89.1 & 16.1 & 6.94 & 4.22 & The egg contained an embryo that was about $2 \mathrm{~cm}$ in diameter \\
\hline 1333 & ST09E1333C & STGE13TBMU08 & Uria lomvia & SE Bering Sea, St. George I. & $7 / 11 / 2008$ & 116.2 & 97.9 & 18.1 & 7.04 & 4.37 & The egg contained a developing embryo. \\
\hline 1334 & ST09E1334C & STGE14TBMU08 & Uria lomvia & SE Bering Sea, St. George I. & $7 / 11 / 2008$ & 101.0 & 88.0 & 12.9 & 7.23 & 4.02 & \\
\hline 1335 & ST09E1335C & STGE15TBMU08 & Uria lomvia & SE Bering Sea, St. George I. & $7 / 11 / 2008$ & 107.3 & 91.9 & 14.9 & 7.05 & 4.14 & \\
\hline
\end{tabular}


Appendix 2 (continued).

\begin{tabular}{|c|c|c|c|c|c|c|c|c|c|c|c|}
\hline \multirow{2}{*}{ Number } & \multicolumn{2}{|l|}{ ID } & \multirow{2}{*}{ Species } & \multirow{2}{*}{$\begin{array}{l}\text { Colony } \\
\text { Location }\end{array}$} & \multirow{2}{*}{$\begin{array}{c}\text { Collection } \\
\text { Date }\end{array}$} & \multicolumn{3}{|c|}{ Mass (g) } & \multirow[b]{2}{*}{ Length $(\mathrm{cm})$} & \multirow[b]{2}{*}{ Width $(\mathrm{cm})$} & \multirow{2}{*}{ Notes } \\
\hline & Storage & Field & & & & Whole Egg & Contents & Eggshell & & & \\
\hline 1339 & ST09E1339C & SINU05GLGU08 & Larus hyperboreus & Norton Sound, Sinuk River Delta & $6 / 6 / 2008$ & 98.3 & 87.1 & 11.0 & 6.86 & 5.15 & \\
\hline 1340 & ST09E1340C & SINU06GLGU08 & Larus hyperboreus & Norton Sound, Sinuk River Delta & $6 / 6 / 2008$ & 92.5 & 80.8 & 11.4 & 7.21 & 4.96 & \\
\hline 1343 & ST09E1343C & SINU11GLGU08 & Larus hyperboreus & Norton Sound, Sinuk River Delta & $6 / 6 / 2008$ & 96.2 & 87.8 & 8.2 & 7.12 & 5.19 & \\
\hline 1344 & ST09E1344C & SINU12GLGU08 & Larus hyperboreus & Norton Sound, Sinuk River Delta & $6 / 6 / 2008$ & 95.6 & 85.6 & 9.9 & 7.05 & 5.12 & \\
\hline 1345 & ST09E1345C & SINU13GLGU08 & Larus hyperboreus & Norton Sound, Sinuk River Delta & $6 / 6 / 2008$ & 115.8 & 104.3 & 11.2 & 7.51 & 5.40 & \\
\hline 1349 & ST09E1349C & KUKP04GLGU08 & Larus hyperboreus & E Chukchi Sea, Kukpuk River Delta & $7 / 5 / 2008$ & 106.0 & 94.1 & 11.3 & 7.90 & 5.14 & \\
\hline 1351 & ST09E1351C & KUKP06GLGU08 & Larus hyperboreus & E Chukchi Sea, Kukpuk River Delta & $7 / 5 / 2008$ & 94.6 & 83.4 & 10.9 & 6.23 & 4.65 & \\
\hline 1354 & ST09E1354C & KUKP10GLGU08 & Larus hyperboreus & E Chukchi Sea, Kukpuk River Delta & $7 / 5 / 2008$ & 95.8 & 85.7 & 10.1 & 6.51 & 4.55 & \\
\hline 1357 & ST09E1357C & KUKP13GLGU08 & Larus hyperboreus & E Chukchi Sea, Kukpuk River Delta & $7 / 5 / 2008$ & 108.3 & 96.5 & 11.5 & 7.31 & 4.68 & \\
\hline 1358 & ST09E1358C & KUKP14GLGU08 & Larus hyperboreus & E Chukchi Sea, Kukpuk River Delta & $7 / 5 / 2008$ & 109.0 & 96.1 & 11.2 & 7.45 & 5.30 & \\
\hline 1365 & ST09E1365C & SAFE06GLGU08 & Larus hyperboreus & Norton Sound, Safety Sound & $6 / 12 / 2008$ & 101.6 & 88.1 & 11.1 & 7.27 & 5.13 & \\
\hline 1367 & ST09E1367C & SAFE08GLGU08 & Somateria mollissima? & Norton Sound, Safety Sound & $6 / 12 / 2008$ & 100.3 & 88.5 & 11.6 & 6.93 & 5.14 & \\
\hline 1368 & ST09E1368C & SAFE09GLGU08 & Larus hyperboreus & Norton Sound, Safety Sound & $6 / 12 / 2008$ & 112.6 & 100.2 & 12.3 & 7.72 & 5.19 & \\
\hline 1369 & ST09E1369C & SAFE10GLGU08 & Larus hyperboreus & Norton Sound, Safety Sound & $6 / 12 / 2008$ & 117.4 & 100.9 & 11.8 & 7.73 & 5.39 & \\
\hline 1370 & ST09E1370C & SAFE12GLGU08 & Larus hyperboreus & Norton Sound, Safety Sound & $6 / 12 / 2008$ & 113.5 & 96.2 & 16.5 & 7.17 & 5.44 & \\
\hline 1371 & ST09E1371C & CDAR01GLGU08 & Larus hyperboreus & Norton Sound, Cape Darby & $6 / 12 / 2008$ & 91.9 & 75.8 & 15.9 & 7.40 & 4.96 & \\
\hline 1374 & ST09E1374C & CDAR04GLGU08 & Larus hyperboreus & Norton Sound, Cape Darby & $6 / 12 / 2008$ & 101.7 & 91.3 & 9.6 & 7.28 & 5.09 & \\
\hline 1377 & ST09E1377C & CDAR07GLGU08 & Larus hyperboreus & Norton Sound, Cape Darby & $6 / 12 / 2008$ & 111.3 & 99.1 & 11.8 & 7.58 & 5.22 & \\
\hline 1379 & ST09E1379C & CDAR09GLGU08 & Larus hyperboreus & Norton Sound, Cape Darby & $6 / 12 / 2008$ & 115.5 & 102.8 & 12.5 & 7.59 & 5.35 & \\
\hline 1380 & ST09E1380C & CDAR10GLGU08 & Larus hyperboreus & Norton Sound, Cape Darby & $6 / 12 / 2008$ & 122.2 & 110.6 & 10.5 & 7.79 & 5.39 & \\
\hline 1384 & ST09E1384C & BLUF06GLGU08 & Larus hyperboreus & Norton Sound, Bluff & 6/9/2008 & 103.3 & 85.7 & 17.1 & 6.63 & 4.78 & Several grams of contents remained in the shell. \\
\hline 1385 & ST09E1385C & BLUF07GLGU08 & Larus hyperboreus & Norton Sound, Bluff & $6 / 9 / 2008$ & 108.4 & 81.8 & 25.5 & 7.18 & 4.68 & Several grams of contents remained in the shell. \\
\hline 1388 & ST09E1388C & BLUF10GLGU08 & Larus hyperboreus & Norton Sound, Bluff & 6/9/2008 & 104.4 & 92.6 & 11.0 & 7.47 & 4.57 & \\
\hline 1389 & ST09E1389C & BLUF11GLGU08 & Larus hyperboreus & Norton Sound, Bluff & 6/9/2008 & 113.7 & 102.3 & 10.7 & 7.28 & 4.88 & The egg contained a small embryo. \\
\hline 1390 & ST09E1390C & GOBA01GLGU08 & Larus hyperboreus & Norton Sound, Carolyn I. (Golovin Bay) & $6 / 12 / 2008$ & 97.1 & 87.2 & 9.8 & 7.37 & 4.97 & \\
\hline 1393 & ST09E1393C & GOBA04GLGU08 & Larus hyperboreus & Norton Sound, Carolyn I. (Golovin Bay) & $6 / 12 / 2008$ & 115.2 & 104.6 & 10.2 & 6.71 & 4.98 & \\
\hline 1394 & ST09E1394C & GOBA06GLGU08 & Larus hyperboreus & Norton Sound, Carolyn I. (Golovin Bay) & $6 / 12 / 2008$ & 120.7 & 106.3 & 13.9 & 7.44 & 4.83 & \\
\hline 1397 & ST09E1397C & GOBA09GLGU08 & Larus hyperboreus & Norton Sound, Carolyn I. (Golovin Bay) & $6 / 12 / 2008$ & 123.5 & 108.0 & 14.1 & 7.10 & 5.00 & \\
\hline 1398 & ST09E1398C & GOBA10GLGU08 & Larus hyperboreus & Norton Sound, Carolyn I. (Golovin Bay) & $6 / 12 / 2008$ & 98.1 & 88.3 & 9.5 & 6.69 & 4.50 & \\
\hline 1401 & ST09E1401C & SHAK02GLGU08 & Larus hyperboreus & Norton Sound, Shaktoolik South & $6 / 8 / 2008$ & 100.4 & 83.1 & 17.0 & 7.50 & 4.96 & Two egg clutch, 1 egg broken \\
\hline 1402 & ST09E1402C & SHAK03GLGU08 & Larus hyperboreus & Norton Sound, Shaktoolik South & $6 / 8 / 2008$ & 115.4 & 92.4 & 15.0 & 7.74 & 5.27 & Two egg clutch, 1 egg broken \\
\hline 1403 & ST09E1403C & SHAK04GLGU08 & Larus hyperboreus & Norton Sound, Shaktoolik South & $6 / 8 / 2008$ & 110.5 & 95.8 & 14.5 & 7.52 & 5.23 & Two egg clutch, 1 egg broken \\
\hline 1404 & ST09E1404C & SHAK05GLGU08 & Larus hyperboreus & Norton Sound, Shaktoolik South & $6 / 8 / 2008$ & 97.2 & 88.4 & 9.2 & 7.58 & 4.87 & Two egg clutch, 1 egg broken \\
\hline \multirow{2}{*}{1407} & ST09E1407C & TINC01GLGU08 & Larus hyperboreus & NW Seward Peninsula, Tin Creek (SE of Shishmaref) & $6 / 17 / 2008$ & 100.2 & 88.7 & 11.4 & 6.96 & 4.80 & \\
\hline & $\mathrm{S} 109 \mathrm{E} 140 / \mathrm{C}$ & MINCUIGLGUUO & Larus nyperboreus & NW SeWara Peninsula, Iincreek (SE or Snisminarer) & $0 / 1 / 1 / 2008$ & 89.9 & 79.8 & 9.8 & 6.79 & 4.61 & \\
\hline \multirow{3}{*}{1411} & & & & & & 90.8 & 81.6 & 9.2 & 6.75 & 4.70 & \\
\hline & ST09E1411C & TINC05GLGU08 & Larus hyperboreus & NW Seward Peninsula, Tin Creek (SE of Shishmaref) & $6 / 17 / 2008$ & 93.0 & 83.7 & 9.2 & 6.82 & 4.67 & \\
\hline & & & & & & 88.6 & 68.2 & 16.3 & 6.51 & 4.56 & \\
\hline \multirow{3}{*}{1414} & & & & & & 99.9 & 90.0 & 8.8 & 7.19 & 4.77 & \\
\hline & ST09E1414C & SHFB03GLGU08 & Larus hyperboreus & NW Seward Peninsula, Arctic Lagoon (SSE of Shishmaref) & $6 / 16 / 2008$ & 111.3 & 98.8 & 11.7 & 7.81 & 4.78 & \\
\hline & & & & & & 95.4 & 84.7 & 10.6 & 7.61 & 4.74 & \\
\hline \multirow{3}{*}{1415} & & & & & & 97.0 & 87.0 & 9.6 & 6.85 & 4.70 & \\
\hline & ST09E1415C & SHFB04GLGU08 & Larus hyperboreus & NW Seward Peninsula, Arctic Lagoon (SSE of Shishmaref) & $6 / 16 / 2008$ & 103.8 & 90.5 & 9.8 & 6.64 & 4.89 & \\
\hline & & & & & & 73.8 & 58.8 & 14.3 & 6.42 & 4.34 & \\
\hline 1416 & ST09E1416C & SHFB05GLGU08 & Larus hyperboreus & NW Seward Peninsula, Arctic Lagoon (SSE of Shishmaref) & 6/16/2008 & $\begin{array}{l}85.8 \\
88.8\end{array}$ & $\begin{array}{l}76.2 \\
79.9\end{array}$ & $\begin{array}{r}9.1 \\
83\end{array}$ & $\begin{array}{l}6.32 \\
648\end{array}$ & $\begin{array}{l}4.58 \\
458\end{array}$ & Three egg clutch, 1 egg broken \\
\hline
\end{tabular}


Appendix 2 (continued).

\begin{tabular}{|c|c|c|c|c|c|c|c|c|c|c|c|}
\hline \multicolumn{3}{|c|}{ ID } & \multirow{2}{*}{ Species } & \multirow{2}{*}{$\begin{array}{c}\begin{array}{c}\text { Colony } \\
\text { Location }\end{array} \\
\end{array}$} & \multirow{2}{*}{$\begin{array}{c}\text { Collection } \\
\text { Date }\end{array}$} & \multicolumn{3}{|c|}{ Mass (g) } & \multirow[b]{2}{*}{ Length $(\mathrm{cm})$} & \multirow[b]{2}{*}{ Width (cm) } & \multirow{2}{*}{ Notes } \\
\hline Number & Storage & Field & & & & Whole Egg & Contents & Eggshell & & & \\
\hline 1419 & ST10E1419C & $\begin{array}{l}\text { STUA03GLGU09 } \\
\end{array}$ & Larus hyperboreus & Norton Sound, Stuart Island (South River A) & $6 / 8 / 2009$ & 88.64 & 78.8 & 9.73 & 7.6 & 4.7 & Egg had a small, $2 \mathrm{~cm}$ embryo. \\
\hline 1420 & ST10E1420C & STUA04GLGU09 & Larus hyperboreus & Norton Sound, Stuart Island (South River A) & 6/8/2009 & $\begin{array}{r}103.93 \\
99.47\end{array}$ & $\begin{array}{l}90.51 \\
86.31\end{array}$ & $\begin{array}{l}12.86 \\
12.16\end{array}$ & $\begin{array}{l}7.44 \\
7.29\end{array}$ & $\begin{array}{l}5.26 \\
5.15\end{array}$ & Egg A had a small, $2 \mathrm{~cm}$ embryo and Egg B had a $1.5 \mathrm{~cm}$ embryo. \\
\hline 1421 & ST10E1421C & STUA05GLGU09 & Larus hyperboreus & Norton Sound, Stuart Island (South River A) & 6/8/2009 & 95.25 & 81.65 & 12.92 & 7.82 & 4.83 & Egg had a small, $2 \mathrm{~cm}$ embryo. \\
\hline 1422 & ST10E1422C & STUA06GLGU09 & Larus hyperboreus & Norton Sound, Stuart Island (South River A) & $6 / 8 / 2009$ & 105.49 & 91.14 & 13.57 & 7.62 & 5.2 & Egg A had a small, $2 \mathrm{~cm}$ embryo,Egg B was broken and discarded. \\
\hline 1423 & ST10E1423C & STUA07GLGU09 & Larus hyperboreus & Norton Sound, Stuart Island (South River A) & $6 / 8 / 2009$ & 99.33 & 87.9 & 10.94 & 7.38 & 5.28 & Egg had a $2.5-3.0 \mathrm{~cm}$ embryo with large developing veins and arteries. \\
\hline 1424 & ST10E1424C & SHAK01GLGU09 & Larus hyperboreus & Norton Sound Shaktoolik South & $6 / 22009$ & 116.26 & 101.92 & 11.16 & 7.81 & 5.25 & \\
\hline & & & & & & 113.54 & 101.75 & 8.88 & 7.62 & 5.27 & \\
\hline 1426 & ST10E1426C & SHAK03GLGU09 & Larus hyperboreus & Norton Sound, Shaktoolik South & $6 / 2 / 2009$ & 129.91 & 110.47 & 13.17 & 7.89 & 5.56 & \\
\hline 1427 & ST10E1427C & SHAK04GLGU09 & Larus hyperboreus & Norton Sound, Shaktoolik South & 6/2/2009 & 115.19 & 99.81 & 11.69 & 7.45 & 5.37 & \\
\hline 1428 & ST $10 \mathrm{E} 1428 \mathrm{C}$ & SHAK05GLGU09 & Larus hynerboreus & Norton Sound Shaktoolik South & $6 / 2 / 2009$ & 113.43 & 99.23 & 10.17 & 7.99 & 5.12 & \\
\hline 1720 & S1IVE14200 & 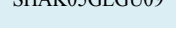 & Lartus iyperivoreus & Norton souna, Shaktoolik soutn & $6 / 2 / 2009$ & 107.93 & 91.58 & 11.71 & 7.61 & 5.17 & \\
\hline 1429 & ST10E1429C & SHAK06GLGU09 & Larus hyperboreus & Norton Sound, Shaktoolik South & $6 / 2 / 2009$ & 104.68 & 93.18 & 8.52 & 7.31 & 5.17 & \\
\hline & & & & & & 101.53 & 90.35 & 9.35 & 7.35 & 5.08 & \\
\hline 1433 & ST10E1433C & BREV03GLGU09 & Larus hyperboreus & Norton Sound, Brevig Mission KTS & $5 / 30 / 2009$ & 102.89 & 94.59 & 10.48 & 7.48 & 5.05 & \\
\hline & & & & & & 110.83 & 98.14 & 10.9 & 7.87 & 5.16 & \\
\hline 1435 & ST10E1435C & BREV05GLGU09 & Larus hyperboreus & Norton Sound, Brevig Mission KTS & $5 / 30 / 2009$ & 128.16 & 111 & 12.15 & 7.84 & 5.53 & \\
\hline 1436 & ST10E1436C & BREV06GLGU09 & Larus hyperboreus & Norton Sound, Brevig Mission KTS & $5 / 30 / 2009$ & $\begin{array}{l}103.12 \\
91.85\end{array}$ & $\begin{array}{l}89.6 \\
81.55\end{array}$ & $\begin{array}{l}13.52 \\
103\end{array}$ & 7.21 & $\begin{array}{l}5.19 \\
4.95\end{array}$ & \\
\hline & & & & & & $\begin{array}{l}91.85 \\
107.52\end{array}$ & 95.81 & 11.55 & 7.18 & 5.29 & \\
\hline 1439 & ST10E1439C & BREV09GLGU09 & Larus hyperboreus & Norton Sound, Brevig Mission KTS & $5 / 30 / 2009$ & 106.08 & 91.64 & 10.37 & 7.81 & 5.07 & \\
\hline 1441 & ST10E1441C & BREV11GLGU09 & Larus hyperboreus & Norton Sound, Brevig Mission KTS & $5 / 30 / 2009$ & 101.91 & 86.92 & 11.75 & 7.09 & 5.23 & \\
\hline 1443 & ST10E1443C & CDEN02COMU09 & Uria aalge & Norton Sound, Cape Denbigh & 6/19/2009 & 115.9 & 95.61 & 18.39 & 8.56 & 5.07 & \\
\hline 1446 & ST10E1446C & CDEN05COMU09 & Uria aalge & Norton Sound, Cape Denbigh & $6 / 19 / 2009$ & 119.28 & 99.4 & 17.89 & 8.26 & 5.28 & \\
\hline 1448 & ST10E1448C & CDEN07COMU09 & Uria aalge & Norton Sound, Cape Denbigh & 6/19/2009 & 123.21 & 102.02 & 18.81 & 8.86 & 5.17 & \\
\hline 1449 & ST10E1449C & CDEN08COMU09 & Uria aalge & Norton Sound, Cape Denbigh & 6/19/2009 & 113.68 & 95.48 & 15.75 & 8.41 & 5.07 & \\
\hline 1452 & ST10E1452C & CDEN11COMU09 & Uria aalge & Norton Sound, Cape Denbigh & 6/19/2009 & 119.68 & 98.91 & 18.63 & 8.34 & 5.22 & \\
\hline 1454 & ST10E1454C & CLIS01UNMU09 & Uria spp. & E Chukchi Sound, Cape Lisburne & $7 / 5 / 2009$ & 106.84 & 86.22 & 17.62 & 7.3 & 5.91 & \\
\hline 1455 & ST10E1455C & CLIS02UNMU09 & Uria spp. & E Chukchi Sound, Cape Lisburne & $7 / 5 / 2009$ & 109.48 & 90.29 & 17.1 & 8.24 & 5.11 & \\
\hline 1457 & ST10E1457C & CLIS04UNMU09 & Uria spp. & E Chukchi Sound, Cape Lisburne & $7 / 5 / 2009$ & 109.51 & 94.73 & 13.94 & 8.13 & 5.26 & \\
\hline 1458 & ST10E1458C & CLIS05UNMU09 & Uria spp. & E Chukchi Sound, Cape Lisburne & $7 / 5 / 2009$ & 86 & 73.64 & 12.04 & 7.77 & 4.74 & Egg had a $1.4 \mathrm{~cm}$ embryo with developing blood vessels. \\
\hline 1460 & ST10E1460C & CLIS07UNMU09 & Uria spp. & E Chukchi Sound, Cape Lisburne & $7 / 5 / 2009$ & 94.28 & 78.94 & 13.24 & 7.56 & 4.94 & Egg had a $1.5 \mathrm{~cm}$ embryo with developing blood vessels. \\
\hline 1463 & ST10E1463C & STGE03COMU09 & Uria aalge & SE Bering Sea, St. George Island & 6/24/2009 & 118.52 & 97.85 & 17.6 & 8.54 & 5.15 & \\
\hline 1466 & ST10E1466C & STGE06COMU09 & Uria aalge & SE Bering Sea, St. George Island & $6 / 24 / 2009$ & 107.55 & 90.22 & 16.04 & 8.11 & 5.11 & \\
\hline 1469 & ST10E1469C & STGE09COMU09 & Uria aalge & SE Bering Sea, St. George Island & $6 / 24 / 2009$ & 117.69 & 97.05 & 16.48 & 8.59 & 5.19 & \\
\hline 1470 & ST10E1470C & STGE10COMU09 & Uria aalge & SE Bering Sea, St. George Island & $6 / 24 / 2009$ & 119.21 & 100.59 & 16.8 & 8.88 & 5.07 & \\
\hline 1472 & ST10E1472C & STGE12COMU09 & Uria aalge & SE Bering Sea, St. George Island & $6 / 24 / 2009$ & 97.44 & 82.02 & 13.67 & 7.73 & 4.92 & \\
\hline 1473 & ST10E1473C & AIKT01GWGU09 & Larus glaucescens & E. Aleutian Islands, Aiktak Island & $6 / 21 / 2009$ & 111.52 & 96.28 & 11.18 & 7.53 & 5.24 & Egg B was rotten and thrown out. \\
\hline 1474 & ST10E1474C & AIKT02GWGU09 & Larus glaucescens & E. Aleutian Islands, Aiktak Island & $6 / 21 / 2009$ & $\begin{array}{r}99.65 \\
08.08\end{array}$ & 85.92 & 12.46 & 7.39 & 5.04 & \\
\hline 1475 & ST10F1475C & AKTO3GWGUOO & Latus graucescens & 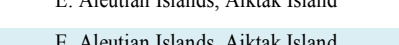 & $0 / 21 / 2009$ & 98.08 & 86.31 & 11.77 & 7 & 5.1 & For $\mathrm{R}$ we cotton ad broun ont \\
\hline 1477 & ST10E1477C & 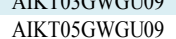 & $\begin{array}{l}\text { Larus glaucescens } \\
\text { Larus glaucescens }\end{array}$ & $\begin{array}{l}\text { E. Aleutan Isiands, Aiktak Iliand } \\
\text { E. Aleutian Islands. Aiktak Island }\end{array}$ & $\begin{array}{l}0 / 21 / 2009 \\
6 / 21 / 2009\end{array}$ & $\begin{array}{l}105.36 \\
9566\end{array}$ & $\begin{array}{r}84.3 \\
84.46\end{array}$ & $\begin{array}{c}13.59 \\
97\end{array}$ & $\begin{array}{l}1.10 \\
7.43\end{array}$ & $\begin{array}{l}5.18 \\
4.93\end{array}$ & $\begin{array}{l}\text { Egg } B \text { was rotten and thrown out. } \\
\text { Eg } B \text { was rotten and thrown out }\end{array}$ \\
\hline 1478 & ST10E1478C & AIKT06GWGU09 & Larus glaucescens & E. Aleutian Islands, Aiktak Island & $6 / 21 / 2009$ & 91.9 & 82.34 & 9.4 & 7.08 & 4.99 & Egg B was rotten and thrown out. \\
\hline 1479 & ST10E1479C & STPA01TBMU09 & Uria lomvia & SE Bering Sea, St. Paul Island & $6 / 24 / 2009$ & 123.82 & 98.98 & 21.06 & 8.41 & 5.31 & \\
\hline 1480 & ST10E1480C & STPA02TBMU09 & Uria lomvia & SE Bering Sea, St. Paul Island & $6 / 24 / 2009$ & 105.5 & 83.22 & 15.13 & 7.61 & 5.09 & \\
\hline 1482 & ST10E1482C & STPA04TBMU09 & Uria lomvia & SE Bering Sea, St. Paul Island & $6 / 24 / 2009$ & 114.3 & 92.18 & 18.49 & 8.61 & 5.06 & \\
\hline 1485 & ST10E1485C & STPA07TBMU09 & Uria lomvia & SE Bering Sea, St. Paul Island & $6 / 24 / 2009$ & 107.52 & 90.54 & 16.64 & 7.94 & 5.07 & \\
\hline 1486 & ST10E1486C & STPA08TBMU09 & Uria lomvia & SE Bering Sea, St. Paul Island & $6 / 24 / 2009$ & 121.1 & 96.97 & 19.86 & 8.18 & 5.35 & \\
\hline
\end{tabular}


Appendix 3. Hg levels (ng g ${ }^{-1}$, wet mass) and stable $\delta^{15} \mathrm{~N}, \delta^{13} \mathrm{C}$ isotopes in murre and gull eggs.

\begin{tabular}{|c|c|c|c|c|c|c|c|}
\hline NIST ID & Field ID & Species & Colony & Region & $\mathrm{Hg}(\mathrm{ng} / \mathrm{g})$ & $\delta^{15} \mathbf{N}$ & $\delta^{13} \mathrm{C}$ \\
\hline ST09E1234C & STLA03COMU08 & Common Murre & St. Lazaria I. & SE Alaska & 205 & 14.30 & -18.71 \\
\hline ST09E1235C & STLA04COMU08 & Common Murre & St. Lazaria I. & SE Alaska & 113 & 13.81 & -19.27 \\
\hline ST09E1236C & STLA05COMU08 & Common Murre & St. Lazaria I. & SE Alaska & 153 & 15.14 & -17.20 \\
\hline ST09E1238C & STLA07COMU08 & Common Murre & St. Lazaria I. & SE Alaska & 236 & 14.49 & -19.46 \\
\hline ST09E1240C & STLA09COMU08 & Common Murre & St. Lazaria I. & SE Alaska & 183 & 14.60 & -19.25 \\
\hline ST09E1242C & STLA01TBMU08 & Thick-billed Murre & St. Lazaria I. & SE Alaska & 158 & 13.29 & -19.06 \\
\hline ST09E1243C & STLA02TBMU08 & Thick-billed Murre & St. Lazaria I. & SE Alaska & 190 & 15.14 & -19.62 \\
\hline ST09E1244C & STLA03TBMU08 & Thick-billed Murre & St. Lazaria I. & SE Alaska & 76 & 13.29 & -19.40 \\
\hline ST09E1245C & STLA04TBMU08 & Thick-billed Murre & St. Lazaria I. & SE Alaska & 166 & 14.92 & -18.78 \\
\hline ST09E1246C & STLA05TBMU08 & Thick-billed Murre & St. Lazaria I. & SE Alaska & 135 & 14.30 & -19.80 \\
\hline ST09E1250C & DIOM04TBMU08 & Thick-billed Murre & Little Diomede & NBS/Chukchi Sea & 75 & 17.13 & -20.49 \\
\hline ST09E1256C & DIOM10TBMU08 & Thick-billed Murre & Little Diomede & NBS/Chukchi Sea & 56 & 17.41 & -19.57 \\
\hline ST09E1257C & DIOM11TBMU08 & Thick-billed Murre & Little Diomede & NBS/Chukchi Sea & 75 & 16.94 & -20.19 \\
\hline ST09E1260C & DIOM14TBMU08 & Thick-billed Murre & Little Diomede & NBS/Chukchi Sea & 97 & 17.30 & -20.10 \\
\hline ST09E1261C & DIOM15TBMU08 & Thick-billed Murre & Little Diomede & NBS/Chukchi Sea & 69 & 17.00 & -20.76 \\
\hline ST09E1265C & STLW04COMU08 & Common Murre & St. Lawrence I. & NBS/Chukchi Sea & 69 & 13.64 & -20.47 \\
\hline ST09E1266C & STLW05COMU08 & Common Murre & St. Lawrence I. & NBS/Chukchi Sea & 36 & 12.85 & -20.93 \\
\hline ST09E1267C & STLW06COMU08 & Common Murre & St. Lawrence I. & NBS/Chukchi Sea & 68 & 15.06 & -18.69 \\
\hline ST09E1268C & STLW07COMU08 & Common Murre & St. Lawrence I. & NBS/Chukchi Sea & 40 & 12.80 & -20.00 \\
\hline ST09E1275C & STLW14COMU08 & Common Murre & St. Lawrence I. & NBS/Chukchi Sea & 49 & 14.98 & -19.42 \\
\hline ST09E1278C & STLW02TBMU08 & Thick-billed Murre & St. Lawrence I. & NBS/Chukchi Sea & 31 & 13.29 & -19.12 \\
\hline ST09E1279C & STLW03TBMU08 & Thick-billed Murre & St. Lawrence I. & NBS/Chukchi Sea & 41 & 13.29 & -19.46 \\
\hline ST09E1281C & STLW05TBMU08 & Thick-billed Murre & St. Lawrence I. & NBS/Chukchi Sea & 36 & 13.62 & -20.86 \\
\hline ST09E1284C & STLW08TBMU08 & Thick-billed Murre & St. Lawrence I. & NBS/Chukchi Sea & 31 & 13.45 & -20.02 \\
\hline ST09E1287C & STLW11TBMU08 & Thick-billed Murre & St. Lawrence I. & NBS/Chukchi Sea & 12 & 13.42 & -19.01 \\
\hline ST09E1292C & SLED01COMU08 & Common Murre & Sledge I. & Norton Sound & 71 & 17.90 & -20.36 \\
\hline ST09E1295C & SLED05COMU08 & Common Murre & Sledge I. & Norton Sound & 92 & 18.39 & -20.34 \\
\hline
\end{tabular}


Appendix 3 (Continued).

\begin{tabular}{|c|c|c|c|c|c|c|c|}
\hline ST09E1301C & SLED11COMU08 & Common Murre & Sledge I. & Norton Sound & 102 & 17.79 & -20.89 \\
\hline ST09E1303C & SLED13COMU08 & Common Murre & Sledge I. & Norton Sound & 58 & 18.12 & -20.31 \\
\hline ST09E1305C & SLED15COMU08 & Common Murre & Sledge I. & Norton Sound & 52 & 18.61 & -19.76 \\
\hline ST09E1307C & BLUF02COMU08 & Common Murre & Bluff & Norton Sound & 143 & 19.07 & -20.99 \\
\hline ST09E1309C & BLUF04COMU08 & Common Murre & Bluff & Norton Sound & 136 & 18.72 & -21.89 \\
\hline ST09E1314C & BLUF09COMU08 & Common Murre & Bluff & Norton Sound & 144 & 19.23 & -19.97 \\
\hline ST09E1319C & BLUF14COMU08 & Common Murre & Bluff & Norton Sound & 82 & 18.80 & -21.61 \\
\hline ST09E1320C & BLUF15COMU08 & Common Murre & Bluff & Norton Sound & 112 & 19.23 & -20.92 \\
\hline ST09E1321C & STGE01TBMU08 & Thick-billed Murre & St. George I. & SBS & 56 & 12.20 & -21.09 \\
\hline ST09E1331C & STGE11TBMU08 & Thick-billed Murre & St. George I. & SBS & 55 & 12.28 & -20.60 \\
\hline ST09E1333C & STGE13TBMU08 & Thick-billed Murre & St. George I. & SBS & 91 & 11.49 & -23.14 \\
\hline ST09E1334C & STGE14TBMU08 & Thick-billed Murre & St. George I. & SBS & 192 & 11.51 & -23.13 \\
\hline ST09E1335C & STGE15TBMU08 & Thick-billed Murre & St. George I. & SBS & 67 & 11.92 & -20.48 \\
\hline ST09E1339C & SINU05GLGU08 & Glaucous Gull & Sinuk River Delta & NBS/Chukchi Sea & 185 & 17.52 & -20.59 \\
\hline ST09E1340C & SINU06GLGU08 & Glaucous Gull & Sinuk River Delta & NBS/Chukchi Sea & 213 & 14.05 & -23.72 \\
\hline ST09E1343C & SINU11GLGU08 & Glaucous Gull & Sinuk River Delta & NBS/Chukchi Sea & 644 & 15.14 & -24.81 \\
\hline ST09E1344C & SINU12GLGU08 & Glaucous Gull & Sinuk River Delta & NBS/Chukchi Sea & 200 & 16.15 & -21.03 \\
\hline ST09E1345C & SINU13GLGU08 & Glaucous Gull & Sinuk River Delta & NBS/Chukchi Sea & 125 & 18.25 & -19.72 \\
\hline ST09E1349C & KUKP04GLGU08 & Glaucous Gull & Kukpuk River Delta & NBS/Chukchi Sea & 77 & 16.40 & -19.54 \\
\hline ST09E1351C & KUKP06GLGU08 & Glaucous Gull & Kukpuk River Delta & NBS/Chukchi Sea & 107 & 15.42 & -20.86 \\
\hline ST09E1354C & KUKP10GLGU08 & Glaucous Gull & Kukpuk River Delta & NBS/Chukchi Sea & 70 & 15.33 & -20.05 \\
\hline ST09E1357C & KUKP13GLGU08 & Glaucous Gull & Kukpuk River Delta & NBS/Chukchi Sea & 63 & 16.40 & -19.46 \\
\hline ST09E1358C & KUKP14GLGU08 & Glaucous Gull & Kukpuk River Delta & NBS/Chukchi Sea & 55 & 15.55 & -20.78 \\
\hline ST09E1365C & SAFE06GLGU08 & Glaucous Gull & Safety Sound & Norton Sound & 132 & 17.19 & -19.96 \\
\hline ST09E1367C & SAFE08GLGU08 & Common Eider? & Safety Sound & Norton Sound & 157 & 18.88 & -19.48 \\
\hline ST09E1368C & SAFE09GLGU08 & Glaucous Gull & Safety Sound & Norton Sound & 165 & 19.21 & -19.58 \\
\hline ST09E1369C & SAFE10GLGU08 & Glaucous Gull & Safety Sound & Norton Sound & 104 & 18.93 & -20.37 \\
\hline ST09E1370C & SAFE12GLGU08 & Glaucous Gull & Safety Sound & Norton Sound & 117 & 18.03 & -21.31 \\
\hline
\end{tabular}


Appendix 3 (Continued).

\begin{tabular}{|c|c|c|c|c|c|c|c|}
\hline ST09E1371C & CDAR01GLGU08 & Glaucous Gull & Cape Darby & Norton Sound & 142 & 17.65 & -22.17 \\
\hline ST09E1374C & CDAR04GLGU08 & Glaucous Gull & Cape Darby & Norton Sound & 140 & 17.32 & -19.50 \\
\hline ST09E1377C & CDAR07GLGU08 & Glaucous Gull & Cape Darby & Norton Sound & 134 & 17.02 & -19.40 \\
\hline ST09E1379C & CDAR09GLGU08 & Glaucous Gull & Cape Darby & Norton Sound & 175 & 17.49 & -21.07 \\
\hline ST09E1380C & CDAR10GLGU08 & Glaucous Gull & Cape Darby & Norton Sound & 116 & 17.87 & -19.66 \\
\hline ST09E1384C & BLUF06GLGU08 & Glaucous Gull & Bluff & Norton Sound & 145 & 19.32 & -20.37 \\
\hline ST09E1385C & BLUF07GLGU08 & Glaucous Gull & Bluff & Norton Sound & 195 & 17.87 & -21.28 \\
\hline ST09E1388C & BLUF10GLGU08 & Glaucous Gull & Bluff & Norton Sound & 285 & 18.17 & -22.48 \\
\hline ST09E1389C & BLUF11GLGU08 & Glaucous Gull & Bluff & Norton Sound & 98 & 17.16 & -20.45 \\
\hline ST09E1390C & GOBA01GLGU08 & Glaucous Gull & Carolyn I. (Golovin Bay) & Norton Sound & 165 & 17.73 & -20.35 \\
\hline ST09E1393C & GOBA04GLGU08 & Glaucous Gull & Carolyn I. (Golovin Bay) & Norton Sound & 150 & 16.78 & -21.24 \\
\hline ST09E1394C & GOBA06GLGU08 & Glaucous Gull & Carolyn I. (Golovin Bay) & Norton Sound & 96 & 16.78 & -21.10 \\
\hline ST09E1397C & GOBA09GLGU08 & Glaucous Gull & Carolyn I. (Golovin Bay) & Norton Sound & 120 & 17.32 & -22.22 \\
\hline ST09E1398C & GOBA10GLGU08 & Glaucous Gull & Carolyn I. (Golovin Bay) & Norton Sound & 83 & 16.75 & -20.05 \\
\hline ST09E1401C & SHAK02GLGU08 & Glaucous Gull & Shaktoolik & Norton Sound & 209 & 18.25 & -20.28 \\
\hline ST09E1402C & SHAK03GLGU08 & Glaucous Gull & Shaktoolik & Norton Sound & 290 & 19.04 & -19.32 \\
\hline ST09E1403C & SHAK04GLGU08 & Glaucous Gull & Shaktoolik & Norton Sound & 250 & 17.87 & -21.48 \\
\hline ST09E1404C & SHAK05GLGU08 & Glaucous Gull & Shaktoolik & Norton Sound & 222 & 17.32 & -21.90 \\
\hline ST09E1407C & TINC01GLGU08 & Glaucous Gull & Shishmaref-Tin Creek & NBS/Chukchi Sea & 107 & 13.42 & -26.24 \\
\hline ST09E1411C & TINC05GLGU08 & Glaucous Gull & Shishmaref-Tin Creek & NBS/Chukchi Sea & 180 & 13.23 & -25.13 \\
\hline ST09E1414C & SHFB03GLGU08 & Glaucous Gull & Shishmaref-Egg I. & NBS/Chukchi Sea & 157 & 13.72 & -22.51 \\
\hline ST09E1415C & SHFB04GLGU08 & Glaucous Gull & Shishmaref-Egg I. & NBS/Chukchi Sea & 172 & 13.53 & -24.96 \\
\hline ST09E1416C & SHFB05GLGU08 & Glaucous Gull & Shishmaref-Egg I. & NBS/Chukchi Sea & 68 & 13.89 & -24.99 \\
\hline ST10E1419C & STUA03GLGU09 & Glaucous Gull & Stuart Island (Stebbins) & Norton Sound & 94 & 14.49 & -22.01 \\
\hline ST10E1420C & STUA04GLGU09 & Glaucous Gull & Stuart Island (Stebbins) & Norton Sound & 227 & 15.88 & -24.76 \\
\hline ST10E1421C & STUA05GLGU09 & Glaucous Gull & Stuart Island (Stebbins) & Norton Sound & 108 & 14.68 & -21.67 \\
\hline ST10E1422C & STUA06GLGU09 & Glaucous Gull & Stuart Island (Stebbins) & Norton Sound & 260 & 14.90 & -24.93 \\
\hline ST10E1423C & STUA07GLGU09 & Glaucous Gull & Stuart Island (Stebbins) & Norton Sound & 87 & 13.92 & -25.34 \\
\hline
\end{tabular}


Appendix 3 (Continued).

\begin{tabular}{|c|c|c|c|c|c|c|c|}
\hline ST10E1424C & SHAK01GLGU09 & Glaucous Gull & Shaktoolik (South) & Norton Sound & 104 & 13.92 & -25.18 \\
\hline ST10E1426C & SHAK03GLGU09 & Glaucous Gull & Shaktoolik (South) & Norton Sound & 158 & 18.61 & -22.12 \\
\hline ST10E1427C & SHAK04GLGU09 & Glaucous Gull & Shaktoolik (South) & Norton Sound & 123 & 15.28 & -23.88 \\
\hline ST10E1428C & SHAK05GLGU09 & Glaucous Gull & Shaktoolik (South) & Norton Sound & 154 & 17.38 & -23.95 \\
\hline ST10E1429C & SHAK06GLGU09 & Glaucous Gull & Shaktoolik (South) & Norton Sound & 164 & 17.41 & -22.98 \\
\hline ST10E1433C & BREV03GLGU09 & Glaucous Gull & Brevig Mission & NBS/Chukchi Sea & 246 & 13.53 & -26.15 \\
\hline ST10E1435C & BREV05GLGU09 & Glaucous Gull & Brevig Mission & NBS/Chukchi Sea & 191 & 15.85 & -20.62 \\
\hline ST10E1436C & BREV06GLGU09 & Glaucous Gull & Brevig Mission & NBS/Chukchi Sea & 162 & 15.63 & -22.31 \\
\hline ST10E1439C & BREV09GLGU09 & Glaucous Gull & Brevig Mission & NBS/Chukchi Sea & 160 & 14.57 & -23.70 \\
\hline ST10E1441C & BREV11GLGU09 & Glaucous Gull & Brevig Mission & NBS/Chukchi Sea & 125 & 13.29 & -25.39 \\
\hline ST10E1443C & CDEN02COMU09 & Common Murre & Cape Denbigh & Norton Sound & 156 & 18.28 & -23.16 \\
\hline ST10E1446C & CDEN05COMU09 & Common Murre & Cape Denbigh & Norton Sound & 92 & 18.03 & -23.33 \\
\hline ST10E1448C & CDEN07COMU09 & Common Murre & Cape Denbigh & Norton Sound & 100 & 18.09 & -23.34 \\
\hline ST10E1449C & CDEN08COMU09 & Common Murre & Cape Denbigh & Norton Sound & 122 & 18.47 & -22.20 \\
\hline ST10E1452C & CDEN11COMU09 & Common Murre & Cape Denbigh & Norton Sound & 189 & 18.63 & -21.92 \\
\hline ST10E1454C & CLIS01UNMU09 & Unknown Murre & Cape Lisburne & NBS/Chukchi Sea & 262 & 17.84 & -21.06 \\
\hline ST10E1455C & CLIS02UNMU09 & Unknown Murre & Cape Lisburne & NBS/Chukchi Sea & 2 & 15.61 & -21.32 \\
\hline ST10E1457C & CLIS04UNMU09 & Unknown Murre & Cape Lisburne & NBS/Chukchi Sea & 11 & 15.58 & -21.63 \\
\hline ST10E1458C & CLIS05UNMU09 & Unknown Murre & Cape Lisburne & NBS/Chukchi Sea & 20 & 15.47 & -22.52 \\
\hline ST10E1460C & CLIS07UNMU09 & Unknown Murre & Cape Lisburne & NBS/Chukchi Sea & 18 & 15.80 & -20.31 \\
\hline ST10E1463C & STGE03COMU09 & Common Murre & St. George I. & SBS & 7 & 11.95 & -22.65 \\
\hline ST10E1466C & STGE06COMU09 & Common Murre & St. George I. & SBS & 8 & 12.39 & -21.59 \\
\hline ST10E1469C & STGE09COMU09 & Common Murre & St. George I. & SBS & 10 & 12.31 & -20.50 \\
\hline ST10E1470C & STGE10COMU09 & Common Murre & St. George I. & SBS & 10 & 12.52 & -21.70 \\
\hline ST10E1472C & STGE12COMU09 & Common Murre & St. George I. & SBS & 10 & 12.39 & -21.06 \\
\hline ST10E1473C & AIKT01GWGU09 & Glaucous-Winged Gull & Aiktak I. & SBS & 125 & 15.28 & -19.89 \\
\hline ST10E1474C & AIKT02GWGU09 & Glaucous-Winged Gull & Aiktak I. & SBS & 98 & 14.82 & -22.15 \\
\hline ST10E1475C & AIKT03GWGU09 & Glaucous-Winged Gull & Aiktak I. & SBS & 55 & 15.01 & -19.03 \\
\hline
\end{tabular}


Appendix 3 (Continued).

\begin{tabular}{|l|l|l|l|l|l|l|l|}
\hline ST10E1477C & AIKT05GWGU09 & Glaucous-Winged Gull & Aiktak I. & SBS & 117 & 15.17 & -20.52 \\
\hline ST10E1478C & AIKT06GWGU09 & Glaucous-Winged Gull & Aiktak I. & SBS & 80 & 14.98 & -19.38 \\
\hline ST10E1479C & STPA01TBMU09 & Thick-billed Murre & St. Paul I. & SBS & 12 & 12.96 & -20.56 \\
\hline ST10E1480C & STPA02TBMU09 & Thick-billed Murre & St. Paul I. & SBS & 16 & 13.67 & -21.57 \\
\hline ST10E1482C & STPA04TBMU09 & Thick-billed Murre & St. Paul I. & SBS & 9 & 12.50 & -20.80 \\
\hline ST10E1485C & STPA07TBMU09 & Thick-billed Murre & St. Paul I. & SBS & 44 & 15.77 & -20.90 \\
\hline ST10E1486C & STPA08TBMU09 & Thick-billed Murre & St. Paul I. & SBS & 16 & 12.66 & -19.94 \\
\hline
\end{tabular}


Appendix 4. Hg isotopes measured in common and thick-billed murre eggs.

\begin{tabular}{|c|c|c|c|c|c|c|c|c|c|c|}
\hline NIST ID & Species & Colony & $\begin{array}{l}\mathrm{Hg} \\
\left(\mathrm{ng} \mathrm{g}^{-1}\right)\end{array}$ & $\begin{array}{l}\delta^{199} \mathrm{Hg} \\
(\%)\end{array}$ & $\begin{array}{l}\delta^{200} \mathrm{Hg} \\
(\%)\end{array}$ & $\begin{array}{l}\delta^{201} \mathrm{Hg} \\
(\%)\end{array}$ & $\begin{array}{l}\delta^{202} \mathrm{Hg} \\
(\%)\end{array}$ & $\begin{array}{l}\delta^{204} \mathrm{Hg} \\
(\%)\end{array}$ & $\begin{array}{l}\Delta^{199} \mathrm{Hg} \\
(\%)\end{array}$ & $\begin{array}{l}\Delta^{201} \mathrm{Hg} \\
(\% \mathrm{o})\end{array}$ \\
\hline ST09E1234C & $\begin{array}{l}\text { Common } \\
\text { Murre }\end{array}$ & St. Lazaria I. & 205 & 1.56 & 0.55 & 1.89 & 1.02 & 1.45 & 1.3 & 1.13 \\
\hline ST09E1235C & $\begin{array}{l}\text { Common } \\
\text { Murre }\end{array}$ & St. Lazaria I. & 113 & 1.52 & 0.51 & 1.62 & 0.85 & 1.12 & 1.30 & 0.98 \\
\hline ST09E1236C & $\begin{array}{l}\text { Common } \\
\text { Murre }\end{array}$ & St. Lazaria I. & 153 & 1.47 & 0.55 & 1.70 & 0.90 & 1.25 & 1.25 & 1.02 \\
\hline ST09E1238C & $\begin{array}{l}\text { Common } \\
\text { Murre }\end{array}$ & St. Lazaria I. & 236 & 1.53 & 0.64 & 1.9 & 1.18 & 1.73 & 1.23 & 1.01 \\
\hline ST09E1240C & \begin{tabular}{|l} 
Common \\
Murre
\end{tabular} & St. Lazaria I. & 183 & 1.31 & 0.39 & 1.57 & 0.75 & 1.03 & 1.12 & 1.00 \\
\hline ST09E1242C & $\begin{array}{l}\text { Thick-billed } \\
\text { Murre }\end{array}$ & St. Lazaria I. & 158 & 1.47 & 0.51 & 1.69 & 0.84 & 1.24 & 1.25 & 1.06 \\
\hline ST09E1243C & $\begin{array}{l}\text { Thick-billed } \\
\text { Murre }\end{array}$ & St. Lazaria I. & 190 & 1.58 & 0.49 & 1.77 & 0.84 & 1.07 & 1.36 & 1.14 \\
\hline ST09E1244C & $\begin{array}{l}\text { Thick-billed } \\
\text { Murre }\end{array}$ & St. Lazaria I. & 76 & 1.62 & 0.54 & 1.84 & 0.84 & 1.07 & 1.41 & 1.21 \\
\hline ST09E1245C & $\begin{array}{l}\text { Thick-billed } \\
\text { Murre }\end{array}$ & St. Lazaria I. & 166 & 1.47 & 0.61 & 1.88 & 0.98 & 1.41 & 1.23 & 1.14 \\
\hline ST09E1246C & $\begin{array}{l}\text { Thick-billed } \\
\text { Murre }\end{array}$ & St. Lazaria I. & 135 & 1.52 & 0.56 & 1.82 & 0.99 & 1.36 & 1.27 & 1.07 \\
\hline ST09E1250C & $\begin{array}{l}\text { Thick-billed } \\
\text { Murre }\end{array}$ & $\begin{array}{l}\text { Little } \\
\text { Diomede }\end{array}$ & 75 & 0.84 & 0.31 & 1.01 & 0.62 & 0.93 & 0.68 & 0.54 \\
\hline ST09E1256C & $\begin{array}{l}\text { Thick-billed } \\
\text { Murre }\end{array}$ & $\begin{array}{l}\text { Little } \\
\text { Diomede }\end{array}$ & 56 & 0.82 & 0.23 & 0.98 & 0.49 & 0.68 & 0.70 & 0.61 \\
\hline ST09E1257C & $\begin{array}{l}\text { Thick-billed } \\
\text { Murre }\end{array}$ & $\begin{array}{l}\text { Little } \\
\text { Diomede }\end{array}$ & 75 & 1.05 & 0.56 & 1.44 & 1.10 & 1.58 & 0.77 & 0.61 \\
\hline ST09E1260C & $\begin{array}{l}\text { Thick-billed } \\
\text { Murre }\end{array}$ & $\begin{array}{l}\text { Little } \\
\text { Diomede }\end{array}$ & 97 & 0.72 & 0.29 & 0.90 & 0.53 & 0.84 & 0.58 & 0.50 \\
\hline
\end{tabular}


Appendix 4 (Continued).

\begin{tabular}{|c|c|c|c|c|c|c|c|c|c|c|}
\hline ST09E1261C & $\begin{array}{l}\text { Thick-billed } \\
\text { Murre }\end{array}$ & $\begin{array}{l}\text { Little } \\
\text { Diomede }\end{array}$ & 69 & 0.90 & 0.32 & 1.01 & 0.59 & 0.85 & 0.75 & 0.56 \\
\hline ST09E1265C & $\begin{array}{l}\text { Common } \\
\text { Murre }\end{array}$ & $\begin{array}{l}\text { St. Lawrence } \\
\text { I. }\end{array}$ & 69 & 0.97 & 0.28 & 1.12 & 0.62 & 0.77 & 0.81 & 0.65 \\
\hline ST09E1266C & $\begin{array}{l}\text { Common } \\
\text { Murre }\end{array}$ & $\begin{array}{l}\text { St. Lawrence } \\
\text { I. }\end{array}$ & 36 & 1.10 & 0.33 & 1.17 & 0.61 & 0.73 & 0.95 & 0.70 \\
\hline ST09E1267C & $\begin{array}{l}\text { Common } \\
\text { Murre }\end{array}$ & $\begin{array}{ll}\text { St. Lawrence } \\
\text { I. }\end{array}$ & 68 & 1.03 & 0.50 & 1.36 & 0.95 & 1.32 & 0.78 & 0.64 \\
\hline ST09E1268C & $\begin{array}{l}\text { Common } \\
\text { Murre }\end{array}$ & $\begin{array}{ll}\text { St. Lawrence } \\
\text { I. }\end{array}$ & 40 & 1.01 & 0.40 & 1.14 & 0.69 & 0.88 & 0.84 & 0.61 \\
\hline ST09E1275C & $\begin{array}{l}\text { Common } \\
\text { Murre }\end{array}$ & $\begin{array}{ll}\text { St. Lawrence } \\
\text { I. }\end{array}$ & 49 & 0.89 & 0.37 & 1.06 & 0.76 & 1.07 & 0.70 & 0.49 \\
\hline ST09E1278C & $\begin{array}{l}\text { Thick-billed } \\
\text { Murre }\end{array}$ & $\begin{array}{l}\text { St. Lawrence } \\
\text { I. }\end{array}$ & 31 & 0.94 & 0.18 & 0.89 & 0.32 & 0.68 & 0.86 & 0.64 \\
\hline ST09E1279C & $\begin{array}{l}\text { Thick-billed } \\
\text { Murre }\end{array}$ & $\begin{array}{l}\text { St. Lawrence } \\
\text { I. }\end{array}$ & 41 & 1.15 & 0.74 & 1.69 & 1.15 & 1.63 & 0.86 & 0.83 \\
\hline ST09E1281C & $\begin{array}{l}\text { Thick-billed } \\
\text { Murre }\end{array}$ & $\begin{array}{l}\text { St. Lawrence } \\
\text { I. }\end{array}$ & 36 & 1.07 & 0.54 & 1.60 & 1.05 & 1.57 & 0.80 & 0.81 \\
\hline ST09E1284C & $\begin{array}{l}\text { Thick-billed } \\
\text { Murre }\end{array}$ & $\begin{array}{l}\text { St. Lawrence } \\
\text { I. }\end{array}$ & 31 & 1.04 & 0.44 & 1.45 & 1.08 & 1.49 & 0.76 & 0.64 \\
\hline ST09E1287C & $\begin{array}{l}\text { Thick-billed } \\
\text { Murre }\end{array}$ & $\begin{array}{l}\text { St. Lawrence } \\
\text { I. } \\
\end{array}$ & 12 & 1.30 & 0.48 & 1.48 & 0.91 & 1.25 & 1.07 & 0.79 \\
\hline ST09E1292C & \begin{tabular}{|l}
$\begin{array}{l}\text { Common } \\
\text { Murre }\end{array}$ \\
\end{tabular} & Sledge I. & 71 & 0.94 & 0.50 & 1.31 & 0.85 & 1.13 & 0.72 & 0.67 \\
\hline ST09E1295C & $\begin{array}{l}\text { Common } \\
\text { Murre }\end{array}$ & Sledge I. & 92 & 0.73 & 0.44 & 0.93 & 0.61 & 1.01 & 0.58 & 0.47 \\
\hline ST09E1301C & $\begin{array}{l}\text { Common } \\
\text { Murre }\end{array}$ & Sledge I. & 102 & 0.96 & 0.38 & 1.13 & 0.70 & 1.09 & 0.78 & 0.61 \\
\hline ST09E1303C & $\begin{array}{l}\text { Common } \\
\text { Murre }\end{array}$ & Sledge I. & 58 & 0.73 & 0.4 & 1.06 & 0.74 & 1.06 & 0.54 & 0.51 \\
\hline
\end{tabular}


Appendix 4 (Continued).

\begin{tabular}{|c|c|c|c|c|c|c|c|c|c|c|}
\hline ST09E1305C & $\begin{array}{l}\text { Common } \\
\text { Murre }\end{array}$ & Sledge I. & 52 & 0.63 & 0.36 & 0.72 & 0.51 & 0.76 & 0.5 & 0.33 \\
\hline ST09E1307C & $\begin{array}{l}\text { Common } \\
\text { Murre }\end{array}$ & Bluff I. & 143 & 0.63 & 0.17 & 0.61 & 0.26 & 0.32 & 0.56 & 0.41 \\
\hline ST09E1309C & $\begin{array}{l}\text { Common } \\
\text { Murre }\end{array}$ & Bluff I. & 136 & 0.79 & 0.28 & 0.88 & 0.48 & 0.68 & 0.67 & 0.52 \\
\hline ST09E1314C & $\begin{array}{l}\text { Common } \\
\text { Murre }\end{array}$ & Bluff I. & 144 & 0.63 & 0.29 & 0.7 & 0.45 & 0.65 & 0.51 & 0.36 \\
\hline ST09E1319C & $\begin{array}{l}\text { Common } \\
\text { Murre }\end{array}$ & Bluff I. & 82 & 0.88 & 0.25 & 0.85 & 0.33 & 0.46 & 0.79 & 0.61 \\
\hline ST09E1320C & $\begin{array}{l}\text { Common } \\
\text { Murre }\end{array}$ & Bluff I. & 112 & 0.59 & 0.16 & 0.59 & 0.28 & 0.44 & 0.52 & 0.38 \\
\hline ST09E1321C & $\begin{array}{l}\text { Thick-billed } \\
\text { Murre }\end{array}$ & St. George I. & 56 & 1.4 & 0.4 & 1.41 & 0.54 & 0.72 & 1.27 & 1.01 \\
\hline ST09E1331C & $\begin{array}{l}\text { Thick-billed } \\
\text { Murre }\end{array}$ & St. George I. & 55 & 1.24 & 0.29 & 1.21 & 0.43 & 0.43 & 1.13 & 0.88 \\
\hline ST09E1333C & $\begin{array}{l}\text { Thick-billed } \\
\text { Murre }\end{array}$ & St. George I. & 91 & 1.14 & 0.25 & 1.22 & 0.39 & 0.56 & 1.04 & 0.92 \\
\hline ST09E1334C & $\begin{array}{l}\text { Thick-billed } \\
\text { Murre }\end{array}$ & St. George I. & 192 & 1.3 & 0.5 & 1.52 & 0.82 & 1.01 & 1.1 & 0.91 \\
\hline ST09E1335C & $\begin{array}{l}\text { Thick-billed } \\
\text { Murre }\end{array}$ & St. George I. & 67 & 1.33 & 0.26 & 1.3 & 0.42 & 0.55 & 1.22 & 0.98 \\
\hline ST10E1443C & $\begin{array}{l}\text { Common } \\
\text { Murre }\end{array}$ & Cape Denbigh & 156 & 0.69 & 0.32 & 0.9 & 0.59 & 0.95 & 0.54 & 0.45 \\
\hline ST10E1446C & $\begin{array}{l}\text { Common } \\
\text { Murre }\end{array}$ & Cape Denbigh & 92 & 0.79 & 0.25 & 0.89 & 0.51 & 0.74 & 0.66 & 0.51 \\
\hline ST10E1448C & $\begin{array}{l}\text { Common } \\
\text { Murre }\end{array}$ & Cape Denbigh & 100 & 0.77 & 0.24 & 0.82 & 0.45 & 0.59 & 0.65 & 0.48 \\
\hline ST10E1449C & $\begin{array}{l}\text { Common } \\
\text { Murre }\end{array}$ & Cape Denbigh & 122 & 0.71 & 0.3 & 0.87 & 0.55 & 0.8 & 0.57 & 0.46 \\
\hline ST10E1452C & $\begin{array}{l}\text { Common } \\
\text { Murre }\end{array}$ & Cape Denbigh & 189 & 0.68 & 0.27 & 0.85 & 0.47 & 0.69 & 0.56 & 0.49 \\
\hline
\end{tabular}


Appendix 5. Lipids (\%) and organochlorine pesticide mass fractions ( $\mathrm{ng} \mathrm{g}^{-1}$ wet mass, mean \pm standard deviation) in murre egg control material compared to consensus values and maximum limits of detection.

\begin{tabular}{|c|c|c|c|c|c|c|c|c|c|}
\hline \multirow[b]{2}{*}{ Compound } & \multicolumn{5}{|c|}{ Murre Egg CM } & \multicolumn{4}{|c|}{ Max LOD or LOQ } \\
\hline & Consensus Values & \multicolumn{2}{|c|}{2008 Batch } & \multicolumn{2}{|c|}{2009 Batch } & \multicolumn{2}{|c|}{2008 Batch } & \multicolumn{2}{|c|}{ 2009 Batch } \\
\hline$\%$ lipid & $10.7 \pm 0.643$ & \multicolumn{2}{|c|}{10.9} & \multicolumn{2}{|c|}{$8.77 \pm 0.17$} & & & & \\
\hline 2,4'-DDD & $<0.100$ & \multicolumn{2}{|c|}{$<\mathrm{LOQ}$} & \multicolumn{2}{|c|}{$<\mathrm{LOD}$} & \multicolumn{2}{|c|}{0.197} & \multicolumn{2}{|r|}{0.0825} \\
\hline 2,4'-DDT & $0.108 \pm 0.10$ & \multicolumn{2}{|c|}{$<$ LOD } & \multicolumn{2}{|c|}{$<\mathrm{LOQ}$} & \multicolumn{2}{|c|}{0.196} & \multicolumn{2}{|r|}{0.393} \\
\hline 4,4,'-DDD & & \multicolumn{2}{|c|}{$<\mathrm{LOD}$} & \multicolumn{2}{|c|}{$<\mathrm{LOD}$} & \multicolumn{2}{|c|}{0.199} & \multicolumn{2}{|r|}{0.0833} \\
\hline 4,4'-DDE & $69.5 \pm 6.3$ & \multicolumn{2}{|c|}{67.7} & \multicolumn{2}{|c|}{$66.3 \pm 0.16$} & \multicolumn{2}{|c|}{0.242} & \multicolumn{2}{|r|}{0.381} \\
\hline 4,4'-DDT & $<0.100$ & \multicolumn{2}{|c|}{$<\mathrm{LOQ}$} & \multicolumn{2}{|c|}{$<\mathrm{LOD}$} & \multicolumn{2}{|c|}{0.197} & \multicolumn{2}{|r|}{0.0823} \\
\hline $\mathrm{HCB}$ & $34.0 \pm 5.3$ & \multicolumn{2}{|c|}{38.7} & \multicolumn{2}{|c|}{$39.3 \pm 0.26$} & \multicolumn{2}{|c|}{0.0741} & \multicolumn{2}{|r|}{0.0823} \\
\hline$\alpha-\mathrm{HCH}$ & $1.16 \pm 0.18$ & & 20 & & \pm 0.028 & & 02 & & 0.0846 \\
\hline$\beta-\mathrm{HCH}$ & $24.9 \pm 4.3$ & & 4.0 & & $.7 \pm 1.4$ & & 01 & & 0.0841 \\
\hline$\gamma-\mathrm{HCH}$ & $0.342 \pm 0.024$ & & 363 & & \pm 0.0074 & & 00 & & 0.0761 \\
\hline Octachlorosytrene & $0.913 \pm 0.087$ & & 15 & & $1 \pm 0.010$ & & 78 & & 0.0662 \\
\hline Oxychlordane & $7.16 \pm 0.7$ & & 55 & & \pm 0.027 & & 93 & & 0.0807 \\
\hline Pentachlorobenzene & $1.93 \pm 0.5$ & & 09 & & \pm 0.031 & & 650 & & 0.0569 \\
\hline Mirex & $1.58 \pm 0.16$ & & 62 & & \pm 0.028 & & 99 & & 0.0768 \\
\hline Compound & Consensus Values & Gulls & Murres & GLGUs & Murres \& GWGUs & Gulls & Murres & GLGUs & Murres \& GWGUs \\
\hline Cis-chlordane & $0.254 \pm 0.024$ & 0.177 & 0.257 & $0.241 \pm 0.012$ & $0.238 \pm 0.012$ & 0.0742 & 0.156 & 0.0883 & 0.0761 \\
\hline Cis -nonachlor & $1.94 \pm 0.48$ & 1.90 & 2.03 & $2.19 \pm 0.015$ & $2.38 \pm 0.064$ & 0.0746 & 0.0667 & 0.121 & 0.465 \\
\hline Trans-chlordane & $<0.100$ & 0.145 & 0.149 & $<$ LOD & $<\mathrm{LOD}$ & 0.0750 & 0.0671 & 0.0769 & 0.0769 \\
\hline Trans -nonachlor & $0.481 \pm 0.1$ & 0.402 & 0.400 & $0.437 \pm 0.0055$ & $0.418 \pm 0.0065$ & 0.0748 & 0.0669 & 0.0869 & 0.0767 \\
\hline Heptachlor epoxide & $4.41 \pm 0.3$ & 3.47 & 3.97 & $4.34 \pm 0.10$ & $4.64 \pm 0.16$ & 1.30 & 0.177 & 0.516 & 1.09 \\
\hline
\end{tabular}


Appendix 6. Brominated diphenyl ether (BDE) and polychlorinated biphenyl (PCB) massfractions (ng $\mathrm{g}^{-1}$ wet mass, mean \pm standard deviation) in murre egg control material compared to consensus values and maximum limits of detection (compounds shown in red and blue were above and below reference value ranges, respectively).

\begin{tabular}{|c|c|c|c|c|c|}
\hline \multirow[b]{2}{*}{ Compound } & \multicolumn{3}{|c|}{ Murre Egg Control Material } & \multicolumn{2}{|c|}{ Max LOD or LOQ } \\
\hline & Consensus Values & 2008 & 2009 & 2008 & 2009 \\
\hline BDE47 & $0.771 \pm 0.14$ & 0.817 & $0.733 \pm 0.023$ & 0.147 & 0.0874 \\
\hline BDE99 & $0.530 \pm 0.21$ & $<\mathrm{LOQ}$ & $0.267 \pm 0.022$ & 0.956 & 0.0797 \\
\hline BDE100 & $0.310 \pm 0.13$ & 0.479 & $0.288 \pm 0.017$ & 0.518 & 0.0873 \\
\hline PCB 8 & $<0.100$ & $<$ LOD & $<$ LOD & 0.0256 & 0.00709 \\
\hline PCB 18 & $<0.100$ & $<\mathrm{LOD}$ & $<\mathrm{LOD}$ & 0.0234 & 0.00650 \\
\hline PCB $28+31$ & $2.49 \pm 0.51$ & 2.95 & $2.02 \pm 0.011$ & 0.0737 & 0.0204 \\
\hline РCB 29 & $<0.100$ & $<\mathrm{LOQ}$ & $<\mathrm{LOD}$ & 0.0194 & 0.00117 \\
\hline РCB 44 & $<0.100$ & 0.0577 & $0.0754 \pm 0.0032$ & 0.0445 & 0.0605 \\
\hline PCB 45 & $<0.100$ & 0.00950 & $0.0306 \pm 0.0023$ & 0.00700 & 0.00905 \\
\hline PCB 49 & $<0.100$ & 0.106 & $0.0902 \pm 0.0023$ & 0.0566 & 0.0341 \\
\hline PCB 52 & $0.234 \pm 0.095$ & 0.161 & $0.192 \pm 0.0020$ & 0.0580 & 0.100 \\
\hline РCB 56 & $0.746 \pm 0.059$ & 0.707 & $0.585 \pm 0.023$ & 0.0491 & 0.145 \\
\hline PCB 63 & $0.500 \pm 0.043$ & 0.190 & $0.170 \pm 0.00098$ & 0.205 & 0.0324 \\
\hline PCB 66 & $2.41 \pm 0.12$ & 2.32 & $1.87 \pm 0.069$ & 0.346 & 0.146 \\
\hline PCB 70 & $0.205 \pm 0.018$ & 0.121 & $0.124 \pm 0.0050$ & 0.0260 & 0.0491 \\
\hline РCB 74 & $1.92 \pm 0.061$ & 1.97 & $1.44 \pm 0.041$ & 0.275 & 0.0969 \\
\hline РCB 79 & $0.165 \pm 0.026$ & 0.0221 & $0.0294 \pm 0.0025$ & 0.00740 & 0.0273 \\
\hline PCB 82 & $<0.100$ & 0.0284 & $0.0363 \pm 0.0018$ & 0.0104 & 0.0306 \\
\hline PCB 87 & $0.106 \pm 0.0051$ & 0.0880 & $0.105 \pm 0.0024$ & 0.0437 & 0.0121 \\
\hline РCB 92 & $<0.100$ & 0.0772 & $0.0942 \pm 0.0017$ & 0.0264 & 0.0886 \\
\hline PCB 95+121 & $<0.100$ & $<\mathrm{LOD}$ & $0.0608 \pm 0.0032$ & 0.0732 & 0.0203 \\
\hline PCB 99 & $3.93 \pm 0.17$ & 5.03 & $4.02 \pm 0.10$ & 0.151 & 0.0418 \\
\hline PCB 101 & $0.835 \pm 0.7$ & 0.261 & $0.420 \pm 0.011$ & 0.0868 & 0.142 \\
\hline PCB 105 & $1.84 \pm 0.47$ & 1.86 & $1.72 \pm 0.016$ & 0.0715 & 0.152 \\
\hline PCB 106 & $<0.100$ & 0.0279 & $0.0175 \pm 0.0012$ & 0.0102 & 0.0169 \\
\hline PCB 107 & $0.472 \pm 0.022$ & 0.478 & $0.414 \pm 0.012$ & 0.0226 & 0.0493 \\
\hline PCB 110 & $<0.100$ & $<\mathrm{LOD}$ & $0.0367 \pm 0.0023$ & 0.100 & 0.0278 \\
\hline PCB 112 & & $<\mathrm{LOD}$ & $0.0196 \pm 0.0013$ & 0.00650 & 0.00692 \\
\hline PCB 114 & $0.271 \pm 0.017$ & 0.254 & $0.186 \pm 0.0019$ & 0.0197 & 0.0338 \\
\hline PCB 118 & $6.53 \pm 1.1$ & 7.28 & $5.89 \pm 0.091$ & 0.258 & 0.497 \\
\hline PCB 119 & $<0.100$ & 0.0850 & $0.0870 \pm 0.0060$ & 0.00480 & 0.0101 \\
\hline PCB 127 & $<0.100$ & $<\mathrm{LOD}$ & $<\mathrm{LOQ}$ & 0.0104 & 0.0293 \\
\hline PCB 128 & $0.809 \pm 0.077$ & 0.895 & $0.749 \pm 0.013$ & 0.0660 & 0.0850 \\
\hline PCB 130 & $0.298 \pm 0.018$ & 0.362 & $0.297 \pm 0.012$ & 0.126 & 0.0386 \\
\hline PCB 137 & $1.12 \pm 2.2$ & 0.280 & $0.207 \pm 0.00095$ & 0.0116 & 0.0350 \\
\hline PCB 138 & $5.76 \pm 1.5$ & 5.22 & $4.88 \pm 0.16$ & 0.372 & 0.753 \\
\hline PCB 146 & $2.47 \pm 0.022$ & 2.74 & $2.21 \pm 0.0094$ & 0.0865 & 0.212 \\
\hline PCB 149 & $0.403 \pm 0.1$ & 0.450 & $0.409 \pm 0.019$ & 0.226 & 0.200 \\
\hline
\end{tabular}


Appendix 6 (Continued).

\begin{tabular}{|c|c|c|c|c|c|}
\hline \multirow[b]{2}{*}{ Compound } & \multicolumn{3}{|c|}{ Murre Egg Control Material } & \multicolumn{2}{|c|}{ Max LOD or LOQ } \\
\hline & Consensus Values & 2008 & 2009 & 2008 & 2009 \\
\hline PCB 151 & $<0.100$ & 0.0812 & $0.0152 \pm 0.00036$ & 0.0814 & 0.0155 \\
\hline PCB $153+132$ & $11.0 \pm 0.26$ & 12.8 & $11.1 \pm 0.045$ & 0.670 & 1.26 \\
\hline PCB 154 & $<0.100$ & 0.0994 & $0.0945 \pm 0.00078$ & 0.0725 & 0.0601 \\
\hline PCB 156 & $0.557 \pm 0.12$ & 0.694 & $0.461 \pm 0.0086$ & 0.0896 & 0.0848 \\
\hline PCB 157 & $0.210 \pm 0.014$ & 0.195 & $0.129 \pm 0.0011$ & 0.0415 & 0.0354 \\
\hline PCB 158 & $0.317 \pm 0.063$ & 0.344 & $0.221 \pm 0.014$ & 0.0181 & 0.0562 \\
\hline PCB 159 & $<0.100$ & $<\mathrm{LOQ}$ & $0.00319 \pm 0.00034$ & 0.00740 & 0.00257 \\
\hline PCB 163 & $2.00 \pm 0.16$ & 2.41 & $1.94 \pm 0.0098$ & 0.0852 & 0.205 \\
\hline PCB 165 & $0.117 \pm 0.0090$ & 0.0476 & $0.0406 \pm 0.0022$ & 0.00600 & 0.0360 \\
\hline PCB 166 & $0.253 \pm 0.023$ & 0.0602 & $0.117 \pm 0.0050$ & 0.00940 & 0.0281 \\
\hline PCB 167 & $0.468 \pm 0.037$ & 0.361 & $0.359 \pm 0.012$ & 0.0232 & 0.0542 \\
\hline PCB 170 & $1.47 \pm 0.72$ & 1.25 & $1.01 \pm 0.039$ & 0.0848 & 0.245 \\
\hline PCB 172 & $0.371 \pm 0.028$ & 0.397 & $0.313 \pm 0.0021$ & 0.0206 & 0.0505 \\
\hline PCB 174 & $<0.100$ & 0.0831 & $0.0922 \pm 0.00078$ & 0.0317 & 0.0693 \\
\hline PCB 175 & $0.266 \pm 0.019$ & 0.0669 & $0.0872 \pm 0.0037$ & 0.0122 & 0.0350 \\
\hline PCB 176 & $0.171 \pm 0.024$ & 0.0329 & $0.0345 \pm 0.0030$ & 0.00930 & 0.0339 \\
\hline PCB 177 & $0.395 \pm 0.092$ & 0.304 & $0.340 \pm 0.016$ & 0.0371 & 0.105 \\
\hline PCB 178 & $0.418 \pm 0.019$ & 0.301 & $0.424 \pm 0.0077$ & 0.0301 & 0.0878 \\
\hline PCB $180+193$ & $2.28 \pm 0.18$ & 2.48 & $2.28 \pm 0.017$ & 0.252 & 0.632 \\
\hline PCB 183 & $0.838 \pm 0.094$ & 0.712 & $0.721 \pm 0.019$ & 0.0407 & 0.156 \\
\hline PCB 185 & $<0.100$ & 0.0251 & $0.0229 \pm 0.00053$ & 0.0115 & 0.0149 \\
\hline PCB 187 & $2.94 \pm 0.09$ & 2.63 & $2.89 \pm 0.037$ & 0.198 & 0.151 \\
\hline PCB 188 & $0.194 \pm 0.019$ & 0.0370 & $0.0350 \pm 0.0020$ & 0.00510 & 0.0197 \\
\hline PCB 189 & $<0.100$ & 0.0214 & $<$ LOQ & 0.0196 & 0.0121 \\
\hline PCB 191 & $<0.100$ & 0.0298 & $<\mathrm{LOQ}$ & 0.0129 & 0.0270 \\
\hline PCB 194 & $0.316 \pm 0.029$ & 0.332 & $0.314 \pm 0.011$ & 0.0370 & 0.0775 \\
\hline PCB 195 & $0.148 \pm 0.019$ & 0.139 & $0.131 \pm 0.0023$ & 0.0450 & 0.0506 \\
\hline PCB 196 & $0.724 \pm 0.061$ & 0.758 & $0.558 \pm 0.025$ & 0.462 & 0.336 \\
\hline PCB 197 & $0.148 \pm 0.011$ & 0.0654 & $0.0492 \pm 0.0021$ & 0.00610 & 0.0265 \\
\hline PCB 199 & $0.631 \pm 0.022$ & 2.99 & $2.07 \pm 0.071$ & 0.732 & 0.543 \\
\hline PCB 200 & $<0.100$ & $<\mathrm{LOD}$ & $<\mathrm{LOQ}$ & 0.00490 & 0.0222 \\
\hline PCB 201 & $0.198 \pm 0.017$ & 0.948 & $0.839 \pm 0.022$ & 0.0345 & 0.207 \\
\hline PCB 202 & $<0.100$ & 0.0564 & $<$ LOQ & 0.0371 & 0.147 \\
\hline PCB 205 & $<0.100$ & 0.0257 & $0.0419 \pm 0.0034$ & 0.00520 & 0.0304 \\
\hline PCB 206 & $<0.100$ & 0.169 & $<$ LOQ & 0.0352 & 0.238 \\
\hline PCB 207 & $<0.100$ & 0.0725 & $0.0844 \pm 0.0037$ & 0.0137 & 0.0424 \\
\hline PCB 208 & $<0.100$ & 0.0598 & $<$ LOQ & 0.0249 & 0.0886 \\
\hline PCB 209 & $<0.100$ & 0.166 & $0.0835 \pm 0.0053$ & 0.0379 & 0.0609 \\
\hline
\end{tabular}


Appendix 7. Lipids (\%) and organochlorine pesticide mass fractions ( $\mathrm{ng} \mathrm{g}^{-1}$ wet mass) in unidentified murre eggs collected at Cape Lisburne, Alaska in 2009.

\begin{tabular}{lllllllll}
\hline Compound & $\mathbf{1 4 5 4}$ & $\mathbf{1 4 5 5}$ & $\mathbf{1 4 5 7}$ & $\mathbf{1 4 5 8}$ & $\mathbf{1 4 6 0}$ & Mean & SD & RSD \\
\% Lipid & 7.61 & 9.56 & 9.19 & 11.0 & 9.12 & $\mathbf{9 . 3 1}$ & 1.2 & 13 \\
& & & & & & & & \\
& & & & & & & & \\
& & & & & & & & \\
- & & & & & & & & \\
4,4 -DDE & 37.6 & 48.2 & 37.9 & 49.7 & 29.4 & $\mathbf{4 0 . 6}$ & 8.4 & 21 \\
& & & & & & & & \\
HCB & 53.4 & 76.4 & 52.7 & 65.1 & 42.9 & $\mathbf{5 8 . 1}$ & 13 & 22 \\
$\alpha$-HCH & $<$ LOD & 0.699 & 0.483 & 0.665 & 0.467 & $\mathbf{0 . 5 7 9}$ & 0.12 & 21 \\
$\beta$-HCH & 12.6 & 30.8 & 22.0 & 22.1 & 14.0 & $\mathbf{2 0 . 3}$ & 7.3 & 36 \\
$\gamma$-HCH & 0.574 & 0.160 & $<$ LOD & 0.167 & 0.110 & $\mathbf{0 . 2 5 3}$ & 0.22 & 85 \\
Octachlorosytrene & 1.63 & 2.09 & 1.49 & 1.98 & 1.32 & $\mathbf{1 . 7 0}$ & 0.33 & 19 \\
Oxychlordane & 4.95 & 7.46 & 5.37 & 6.78 & 3.92 & $\mathbf{5 . 7 0}$ & 1.4 & 25 \\
Pentachlorobenzene & 2.81 & 5.46 & 3.11 & 5.28 & 2.90 & $\mathbf{3 . 9 1}$ & 1.3 & 34 \\
Mirex & 1.10 & 2.00 & 1.05 & 1.27 & 0.763 & $\mathbf{1 . 2 4}$ & 0.46 & 37 \\
Cis-chlordane & 0.0794 & 0.134 & $<$ LOD & 0.135 & 0.0889 & $\mathbf{0 . 1 0 9}$ & 0.029 & 27 \\
Cis-nonachlor & 1.23 & 1.47 & 1.09 & 1.42 & 0.935 & $\mathbf{1 . 2 3}$ & 0.22 & 18 \\
& & & & & & & & \\
Trans-nonachlor & 0.165 & 0.149 & 0.0940 & 0.125 & 0.116 & $\mathbf{0 . 1 3 0}$ & 0.028 & 21 \\
Heptachlor epoxide & 2.17 & 4.27 & 3.08 & 3.58 & 2.54 & $\mathbf{3 . 1 3}$ & 0.83 & 27 \\
\hline & & & & & & & & \\
\hline
\end{tabular}


Appendix 8. Lipids (\%) and organochlorine pesticide mass fractions ( $\mathrm{ng} \mathrm{g}^{-1}$ wet mass) in thick-billed murre eggs collected at Little Diomede Island, Alaska in 2008.

\begin{tabular}{lllllllll}
\hline $\begin{array}{l}\text { Compound } \\
\text { \% Lipid }\end{array}$ & $\mathbf{1 2 5 0}$ & $\mathbf{1 2 5 6}$ & $\mathbf{1 2 5 7}$ & $\mathbf{1 2 6 0}$ & $\mathbf{1 2 6 1}$ & Mean & SD & RSD \\
& 8.84 & 10.3 & 9.77 & 9.74 & 10.3 & $\mathbf{9 . 8 0}$ & 0.61 & 6.2 \\
& & & & & & & & \\
& & & & & & & & \\
- & & & & & & & & \\
4,4 -DDE & & & & & & & & \\
& 41.6 & 54.7 & 49.8 & 50.5 & 46.4 & $\mathbf{4 8 . 6}$ & 4.9 & 10 \\
HCB & & & & & & & & \\
$\alpha$-HCH & 63.0 & 65.9 & 57.6 & 67.7 & 49.5 & $\mathbf{6 0 . 7}$ & 7.4 & 12 \\
$\beta$-HCH & 0.836 & 0.705 & 0.387 & 0.396 & 0.514 & $\mathbf{0 . 5 6 8}$ & 0.20 & 35 \\
& 19.5 & 21.7 & 16.2 & 17.8 & 20.5 & $\mathbf{1 9 . 1}$ & 2.2 & 11 \\
Octachlorosytrene & 1.76 & 2.02 & 1.72 & 2.02 & 1.21 & $\mathbf{1 . 7 5}$ & 0.33 & 19 \\
Oxychlordane & 6.18 & 6.46 & 4.83 & 5.16 & 5.00 & $\mathbf{5 . 5 2}$ & 0.74 & 13 \\
Pentachlorobenzene & 2.14 & 1.97 & 1.20 & 1.43 & 1.47 & $\mathbf{1 . 6 4}$ & 0.40 & 24 \\
Mirex & 1.72 & 1.75 & 1.20 & 1.52 & 1.49 & $\mathbf{1 . 5 4}$ & 0.22 & 14 \\
Cis-chlordane & 0.275 & 0.305 & 0.197 & 0.245 & 0.303 & $\mathbf{0 . 2 6 5}$ & 0.045 & 17 \\
Cis-nonachlor & 1.58 & 1.40 & 0.764 & 0.945 & 1.41 & $\mathbf{1 . 2 2}$ & 0.35 & 28 \\
$\begin{array}{l}\text { Trans-chlordane } \\
\text { Trans-nonachlor }\end{array}$ & 0.0673 & 0.0869 & $<$ LOD & $<$ LOD & 0.0669 & $\mathbf{0 . 0 7 3 7}$ & 0.011 & 15 \\
Heptachlor epoxide & 3.01 & 2.88 & 1.83 & 1.87 & 2.64 & $\mathbf{2 . 4 4}$ & 0.56 & 23 \\
\hline & & & & & & & & \\
\hline
\end{tabular}


Appendix 9. Lipids (\%) and organochlorine pesticide mass fractions ( $\mathrm{ng} \mathrm{g}^{-1}$ wet mass) in common murre eggs collected at St. Lawrence Island, Alaska in 2008.

\begin{tabular}{lllllllll}
\hline $\begin{array}{l}\text { Compound } \\
\text { \% Lipid }\end{array}$ & $\mathbf{1 2 6 5}$ & $\mathbf{1 2 6 6}$ & $\mathbf{1 2 6 7}$ & $\mathbf{1 2 6 8}$ & $\mathbf{1 2 7 5}$ & Mean & SD & RSD \\
& 8.29 & 10.6 & 9.58 & 9.13 & 9.11 & $\mathbf{9 . 3 5}$ & 0.86 & 9.2 \\
& & & & & & & & \\
& & & & & & & & \\
- & & & & & & & & \\
4,4'-DDE & 52.3 & 64.6 & 37.3 & 34.5 & 39.8 & $\mathbf{4 5 . 7}$ & 13 & 27 \\
& & & & & & & & \\
HCB & 17.0 & 26.3 & 49.0 & 32.7 & 50.8 & $\mathbf{3 5 . 1}$ & 15 & 42 \\
$\alpha$-HCH & 0.539 & 0.528 & 0.658 & 0.798 & 0.658 & $<$ LOQ & 0.11 & 17 \\
B-HCH & 5.93 & 6.98 & 12.0 & 11.5 & 12.4 & $<$ LOQ & 3.1 & 31 \\
& & & & & & & & \\
Octachlorosytrene & 0.702 & 0.912 & 1.51 & 1.03 & 1.37 & $\mathbf{1 . 1 1}$ & 0.33 & 30 \\
Oxychlordane & 3.11 & 2.64 & 4.28 & 4.18 & 4.63 & $\mathbf{3 . 7 7}$ & 0.85 & 22 \\
Pentachlorobenzene & 0.825 & 1.26 & 2.01 & 0.926 & 1.71 & $\mathbf{1 . 3 5}$ & 0.51 & 38 \\
Mirex & 0.728 & 0.775 & 0.879 & 1.16 & 1.02 & $\mathbf{0 . 9 1 2}$ & 0.18 & 19 \\
Cis-chlordane & 0.215 & 0.257 & 0.199 & 0.220 & 0.217 & $\mathbf{0 . 2 2 2}$ & 0.021 & 9.7 \\
Cis-nonachlor & 0.407 & 0.302 & 0.531 & 0.538 & 0.655 & $\mathbf{0 . 4 8 7}$ & 0.14 & 28 \\
& & & & & & & & \\
Trans-nonachlor & 0.0944 & 0.110 & 0.0665 & 0.0952 & $<$ LOD & $\mathbf{0 . 0 9 1 4}$ & 0.018 & 20 \\
Heptachlor epoxide & 0.865 & 1.22 & 1.43 & 1.54 & 1.40 & $\mathbf{1 . 2 9}$ & 0.26 & 20 \\
\hline & & & & & & & & \\
\hline
\end{tabular}


Appendix 10. Lipids (\%) and organochlorine pesticide mass fractions (ng g ${ }^{-1}$ wet mass) in thickbilled murre eggs collected at St. Lawrence Island, Alaska in 2008.

\begin{tabular}{lllllllll}
\hline $\begin{array}{l}\text { Compound } \\
\text { \% Lipid }\end{array}$ & $\mathbf{1 2 7 8}$ & $\mathbf{1 2 7 9}$ & $\mathbf{1 2 8 1}$ & $\mathbf{1 2 8 4}$ & $\mathbf{1 2 8 7}$ & Mean & SD & RSD \\
& 8.55 & 9.67 & 9.83 & 8.87 & 8.79 & $\mathbf{9 . 1 4}$ & 0.57 & 6.2 \\
& & & & & & & & \\
2,4'-DDT & 0.197 & 0.173 & 0.387 & 0.133 & $<$ LOD & $\mathbf{0 . 2 2 3}$ & 0.11 & 51 \\
- & & & & & & & & \\
4,4'-DDE & 44.7 & 35.4 & 27.5 & 38.8 & 39.9 & $\mathbf{3 7 . 2}$ & 6.4 & 17 \\
& & & & & & & & \\
HCB & 47.2 & 48.0 & 44.4 & 55.3 & 49.0 & $\mathbf{4 8 . 8}$ & 4.0 & 8.2 \\
$\alpha-H C H$ & 0.576 & 0.709 & 0.471 & 0.724 & 0.871 & $\mathbf{0 . 6 7 0}$ & 0.15 & 23 \\
$\beta$-HCH & 17.5 & 12.6 & 9.23 & 13.9 & 0.0808 & $\mathbf{1 0 . 7}$ & 6.6 & 62 \\
& & & & & & & & \\
Octachlorosytrene & 1.49 & 1.39 & 1.22 & 1.63 & 1.58 & $\mathbf{1 . 4 6}$ & 0.17 & 11 \\
Oxychlordane & 5.39 & 3.68 & 2.99 & 4.73 & 5.34 & $\mathbf{4 . 4 3}$ & 1.1 & 24 \\
Pentachlorobenzene & 1.21 & 1.37 & 0.998 & 1.68 & 1.03 & $\mathbf{1 . 2 6}$ & 0.28 & 22 \\
Mirex & 1.11 & 1.11 & 1.02 & 1.50 & 1.31 & $\mathbf{1 . 2 1}$ & 0.19 & 16 \\
Cis-chlordane & 0.206 & 0.188 & 0.185 & 0.220 & 0.200 & $\mathbf{0 . 2 0 0}$ & 0.014 & 7.2 \\
Cis-nonachlor & 0.739 & 0.415 & 0.302 & 0.597 & 0.680 & $\mathbf{0 . 5 4 7}$ & 0.18 & 34 \\
& & & & & & & & \\
Trans-nonachlor & $<$ LOD & 0.0732 & $<$ LOD & 0.0790 & 0.110 & $\mathbf{0 . 0 8 7 5}$ & 0.020 & 23 \\
Heptachlor epoxide & 2.25 & 1.33 & 1.06 & 1.66 & 0.901 & $\mathbf{1 . 4 4}$ & 0.53 & 37 \\
\hline & & & & & & & & \\
\hline
\end{tabular}


Appendix 11. Lipids (\%) and organochlorine pesticide mass fractions (ng $\mathrm{g}^{-1}$ wet mass) in common murre eggs collected at Sledge Island, Alaska in 2008.

\begin{tabular}{lllllllll}
\hline Compound & $\mathbf{1 2 9 2}$ & $\mathbf{1 2 9 5}$ & $\mathbf{1 3 0 1}$ & $\mathbf{1 3 0 3}$ & $\mathbf{1 3 0 5}$ & Mean & SD & RSD \\
\% Lipid & 8.66 & 7.57 & 9.66 & 9.95 & 9.83 & $\mathbf{9 . 1 4}$ & 1.0 & 11 \\
& & & & & & & & \\
& & & & & & & & \\
& & & & & & & & \\
$4,4, '$-DDD & $<$ LOD & $<$ LOD & 0.105 & 0.0777 & 0.155 & $\mathbf{0 . 1 1 3}$ & 0.039 & 35 \\
4,4 '-DDE & 31.2 & 34.6 & 45.3 & 37.8 & 45.8 & $\mathbf{3 8 . 9}$ & 6.5 & 17 \\
4,4 '-DDT & $<$ LOQ & $<$ LOQ & 0.174 & 0.142 & 0.128 & $\mathbf{0 . 1 4 8}$ & 0.023 & 16 \\
HCB & 42.7 & 54.9 & 37.7 & 51.5 & 64.6 & $\mathbf{5 0 . 3}$ & 11 & 21 \\
$\alpha$-HCH & 0.526 & 0.449 & 0.657 & 0.676 & 0.497 & $\mathbf{0 . 5 6 1}$ & 0.10 & 18 \\
$\beta$-HCH & 15.1 & 12.5 & 11.7 & 21.9 & 32.6 & $\mathbf{1 8 . 8}$ & 8.7 & 47 \\
& & & & & & & & \\
Octachlorosytrene & 1.12 & 1.76 & 1.18 & 1.38 & 1.88 & $\mathbf{1 . 4 6}$ & 0.34 & 23 \\
Oxychlordane & 3.75 & 4.10 & 3.83 & 4.85 & 7.65 & $\mathbf{4 . 8 3}$ & 1.6 & 34 \\
Pentachlorobenzene & 0.690 & 1.04 & 1.14 & 1.38 & 1.07 & $\mathbf{1 . 0 6}$ & 0.25 & 23 \\
Mirex & 1.06 & 1.55 & 1.20 & 1.59 & 2.67 & $\mathbf{1 . 6 1}$ & 0.63 & 39 \\
Cis-chlordane & 0.282 & 0.223 & 0.278 & 0.336 & 0.686 & $\mathbf{0 . 3 6 1}$ & 0.19 & 52 \\
Cis-nonachlor & 1.01 & 0.706 & 0.923 & 1.41 & 5.70 & $\mathbf{1 . 9 5}$ & 2.1 & 110 \\
Trans-chlordane & $<$ LOD & $<$ LOD & 0.112 & 0.0868 & 0.832 & $\mathbf{0 . 3 4 4}$ & 0.42 & 120 \\
Trans-nonachlor & 0.129 & 0.0742 & 0.197 & 0.261 & 3.86 & $\mathbf{0 . 9 0 4}$ & 1.7 & 180 \\
Heptachlor epoxide & 2.08 & 1.49 & 1.73 & 3.16 & 8.06 & $\mathbf{3 . 3 0}$ & 2.7 & 83 \\
\hline & & & & & & & & \\
\hline
\end{tabular}


Appendix 12. Lipids (\%) and organochlorine pesticide mass fractions (ng $\mathrm{g}^{-1}$ wet mass) in common murre eggs collected at Bluff, Alaska in 2008.

\begin{tabular}{lllllllll}
\hline Compound & $\mathbf{1 3 0 7}$ & $\mathbf{1 3 0 9}$ & $\mathbf{1 3 1 4}$ & $\mathbf{1 3 1 9}$ & $\mathbf{1 3 2 0}$ & Mean & SD & RSD \\
\% Lipid & 8.58 & 8.48 & 9.45 & 9.82 & 8.41 & $\mathbf{8 . 9 5}$ & 0.64 & 7.2 \\
& & & & & & & & \\
& & & & & & & & \\
& & & & & & & & \\
- & & & & & & & & \\
4,4 -DDE & 47.6 & 30.9 & 38.5 & 31.0 & 32.3 & $\mathbf{3 6 . 1}$ & 7.1 & 20 \\
& & & & & & & & \\
HCB & 72.6 & 32.7 & 46.3 & 44.4 & 42.4 & $\mathbf{4 7 . 7}$ & 15 & 31 \\
$\alpha-H C H$ & 0.537 & 0.318 & 0.224 & 0.299 & 0.330 & $\mathbf{0 . 3 4 2}$ & 0.12 & 34 \\
$\beta$-HCH & 22.6 & 21.3 & 10.0 & 16.1 & 19.3 & $\mathbf{1 7 . 9}$ & 5.0 & 28 \\
& & & & & & & & \\
Octachlorosytrene & 2.40 & 0.972 & 1.57 & 1.05 & 1.27 & $\mathbf{1 . 4 5}$ & 0.58 & 40 \\
Oxychlordane & 6.23 & 5.05 & 3.49 & 3.75 & 4.46 & $\mathbf{4 . 6 0}$ & 1.1 & 24 \\
Pentachlorobenzene & 1.22 & 0.622 & 0.763 & 1.03 & 0.730 & $\mathbf{0 . 8 7 2}$ & 0.24 & 28 \\
Mirex & 3.63 & 1.85 & 2.34 & 1.54 & 2.31 & $\mathbf{2 . 3 4}$ & 0.80 & 34 \\
Cis-chlordane & 0.234 & 0.318 & 0.167 & 0.200 & 0.200 & $\mathbf{0 . 2 2 4}$ & 0.058 & 26 \\
Cis-nonachlor & 1.35 & 5.51 & 0.480 & 1.05 & 1.61 & $\mathbf{2 . 0 0}$ & 2.0 & 100 \\
& & & & & & & & \\
Trans-nonachlor & 0.153 & 1.94 & $<$ LOD & 0.144 & 0.129 & $\mathbf{0 . 5 9 2}$ & 0.90 & 150 \\
Heptachlor epoxide & 2.76 & 4.84 & 0.870 & 2.10 & 2.94 & $\mathbf{2 . 7 0}$ & 1.4 & 53 \\
\hline
\end{tabular}


Appendix 13. Lipids (\%) and organochlorine pesticide mass fractions (ng $\mathrm{g}^{-1}$ wet mass) in common murre eggs collected at Cape Denbigh, Alaska in 2009.

\begin{tabular}{|c|c|c|c|c|c|c|c|c|}
\hline Compound & 1443 & 1446 & 1448 & 1449 & 1452 & Mean & SD & RSD \\
\hline$\%$ Lipid & 8.11 & 8.48 & 8.92 & 9.12 & 8.86 & 8.70 & 0.40 & 4.6 \\
\hline- & & & & & & & & \\
\hline 4,4'-DDE & 21.8 & 28.6 & 30.3 & 35.2 & 34.0 & 30.0 & 5.3 & 18 \\
\hline $\mathrm{HCB}$ & 47.2 & 41.8 & 49.1 & 51.8 & 52.8 & 48.5 & 4.4 & 9.0 \\
\hline$\beta-\mathrm{HCH}$ & 17.4 & 13.0 & 21.5 & 8.42 & 20.7 & 16.2 & 5.5 & 34 \\
\hline Octachlorosytrene & 1.26 & 1.12 & 1.39 & 1.48 & 1.27 & 1.30 & 0.14 & 11 \\
\hline Oxychlordane & 2.82 & 2.54 & 4.88 & 2.55 & 3.74 & 3.31 & 1.0 & 30 \\
\hline Pentachlorobenzene & 1.59 & 2.86 & 2.21 & 2.86 & 2.84 & 2.47 & 0.56 & 23 \\
\hline Mirex & 1.27 & 0.993 & 1.70 & 0.918 & 1.81 & 1.34 & 0.40 & 30 \\
\hline Cis-chlordane & 0.0782 & $<\mathrm{LOD}$ & 0.157 & 0.255 & 0.128 & 0.154 & 0.074 & 48 \\
\hline Cis-nonachlor & 1.14 & 0.860 & 1.42 & 0.792 & 1.98 & 1.24 & 0.48 & 39 \\
\hline Trans-nonachlor & 0.0826 & $<\mathrm{LOD}$ & 0.171 & $<\mathrm{LOD}$ & 0.267 & 0.173 & 0.092 & 53 \\
\hline Heptachlor epoxide & 2.26 & 1.79 & 3.00 & 1.57 & 2.94 & 2.31 & 0.65 & 28 \\
\hline
\end{tabular}


Appendix 14. Lipids (\%) and organochlorine pesticide mass fractions (ng g ${ }^{-1}$ wet mass) in thickbilled murre eggs collected at St. Paul Island Alaska in 2009.

\begin{tabular}{lllllllll}
\hline Compound & $\mathbf{1 4 7 9}$ & $\mathbf{1 4 8 0}$ & $\mathbf{1 4 8 2}$ & $\mathbf{1 4 8 5}$ & $\mathbf{1 4 8 6}$ & Mean & SD & RSD \\
\% Lipid & 9.46 & 9.55 & 10.0 & 9.45 & 9.00 & $\mathbf{9 . 5 0}$ & 0.36 & 3.8 \\
& & & & & & & & \\
& & & & & & & & \\
& & & & & & & & \\
- & & & & & & & & \\
4,4'-DDE & 52.2 & 77.3 & 39.4 & 28.6 & 38.3 & $\mathbf{4 7 . 2}$ & 19 & 40 \\
& & & & & & & & \\
HCB & 33.2 & 39.7 & 32.6 & 49.5 & 23.5 & $\mathbf{3 5 . 7}$ & 9.6 & 27 \\
$\alpha$-HCH & 0.648 & 0.571 & 0.361 & 0.413 & 0.466 & $\mathbf{0 . 4 9 2}$ & 0.12 & 24 \\
$\beta$-HCH & 16.0 & 13.3 & 15.0 & 24.2 & 7.62 & $\mathbf{1 5 . 2}$ & 6.0 & 39 \\
$\gamma$-HCH & 0.215 & 0.165 & 0.178 & 0.171 & 0.197 & $\mathbf{0 . 1 8 5}$ & 0.021 & 11 \\
Octachlorosytrene & 0.788 & 0.972 & 0.791 & 1.05 & 0.689 & $\mathbf{0 . 8 5 9}$ & 0.15 & 17 \\
Oxychlordane & 4.35 & 3.47 & 2.90 & 4.71 & 1.98 & $\mathbf{3 . 4 8}$ & 1.1 & 32 \\
Pentachlorobenzene & 3.98 & 2.47 & 1.61 & 4.31 & 2.62 & $\mathbf{3 . 0 0}$ & 1.1 & 37 \\
Mirex & 0.855 & 1.00 & 0.873 & 0.899 & 0.395 & $\mathbf{0 . 8 0 5}$ & 0.24 & 29 \\
& & & & & & & & \\
Cis-nonachlor & 0.889 & 0.635 & 0.874 & 1.17 & 0.535 & $\mathbf{0 . 8 2 1}$ & 0.25 & 30 \\
& & & & & & & & \\
$\begin{array}{l}\text { Trans-nonachlor } \\
\text { Heptachlor epoxide }\end{array}$ & 2.81 & 1.85 & 2.13 & 3.89 & 1.63 & $\mathbf{2 . 4 6}$ & 0.92 & 37 \\
\hline & & & & & & & & \\
\hline
\end{tabular}


Appendix 15. Lipids (\%) and organochlorine pesticide mass fractions (ng g ${ }^{-1}$ wet mass) in thickbilled murre eggs collected at St. George Island, Alaska in 2008.

\begin{tabular}{|c|c|c|c|c|c|c|c|c|}
\hline Compound & 1321 & 1331 & 1333 & 1334 & 1335 & Mean & SD & RSD \\
\hline$\%$ Lipid & 10.0 & 10.8 & 11.5 & 9.45 & 8.97 & 10.1 & 1.0 & 9.9 \\
\hline 2,4'-DDT & 0.186 & 0.0895 & $<\mathrm{LOD}$ & $<$ LOD & $<\mathrm{LOD}$ & 0.138 & 0.068 & 49 \\
\hline 4,4,'-DDD & 0.285 & 0.185 & $<\mathrm{LOD}$ & 0.163 & $<\mathrm{LOD}$ & 0.211 & 0.065 & 31 \\
\hline 4,4'-DDE & 117 & 98.1 & 99.4 & 91.6 & 98.9 & 101 & 9.3 & 9.2 \\
\hline 4,4'-DDT & 0.167 & 0.373 & $<\mathrm{LOQ}$ & $<\mathrm{LOQ}$ & 0.222 & 0.254 & 0.11 & 42 \\
\hline $\mathrm{HCB}$ & 28.8 & 19.0 & 33.5 & 16.5 & 21.4 & 23.8 & 7.1 & 30 \\
\hline$\alpha-\mathrm{HCH}$ & 0.782 & 1.42 & 0.954 & 0.998 & 1.15 & 1.06 & 0.24 & 23 \\
\hline$\beta-\mathrm{HCH}$ & 10.8 & 7.40 & 10.6 & 5.61 & 7.59 & 8.40 & 2.2 & 27 \\
\hline Octachlorosytrene & 1.14 & 0.865 & 1.05 & 0.834 & 0.922 & 0.962 & 0.13 & 14 \\
\hline Oxychlordane & 5.52 & 4.16 & 4.61 & 2.99 & 3.39 & 4.13 & 1.0 & 24 \\
\hline Pentachlorobenzene & 0.981 & 0.167 & 0.948 & 0.712 & 0.467 & 0.655 & 0.34 & 52 \\
\hline Mirex & 1.53 & 1.23 & 1.13 & 1.09 & 1.23 & 1.24 & 0.17 & 14 \\
\hline Cis-chlordane & 0.296 & 0.375 & 0.219 & 0.190 & 0.224 & 0.261 & 0.075 & 29 \\
\hline Cis-nonachlor & 0.694 & 0.810 & 0.162 & 0.135 & 0.541 & 0.468 & 0.31 & 66 \\
\hline Trans-nonachlor & 0.120 & 0.180 & 0.0754 & 0.0951 & 0.0700 & 0.108 & 0.045 & 41 \\
\hline Heptachlor epoxide & 1.50 & 1.24 & 1.42 & 0.997 & 1.25 & 1.28 & 0.20 & 15 \\
\hline
\end{tabular}


Appendix 16. Lipids (\%) and organochlorine pesticide mass fractions (ng $\mathrm{g}^{-1}$ wet mass) in common murre eggs collected at St. George Island, Alaska in 2009.

\begin{tabular}{|c|c|c|c|c|c|c|c|c|}
\hline Compound & 1463 & 1466 & 1469 & 1470 & 1472 & Mean & SD & RSD \\
\hline$\%$ Lipid & 8.23 & 9.39 & 8.25 & 8.92 & 10.1 & 8.97 & 0.78 & 8.7 \\
\hline 2,4'-DDT & $<$ LOQ & $<\mathrm{LOQ}$ & $<\mathrm{LOQ}$ & 0.436 & 0.580 & 0.508 & 0.10 & 20 \\
\hline $4,4^{\prime}-\mathrm{DDE}$ & 32.7 & 36.2 & 36.4 & 34.5 & 33.8 & 34.7 & 1.6 & 4.5 \\
\hline $\mathrm{HCB}$ & 41.5 & 42.1 & 34.5 & 41.5 & 45.1 & 40.9 & 3.9 & 9.5 \\
\hline$\alpha-\mathrm{HCH}$ & 0.932 & 1.10 & 0.448 & 1.05 & 0.744 & 0.854 & 0.26 & 31 \\
\hline$\beta-\mathrm{HCH}$ & 28.1 & 26.6 & 14.4 & 20.8 & 19.4 & 21.8 & 5.6 & 26 \\
\hline$\gamma-\mathrm{HCH}$ & 0.253 & 0.387 & 0.133 & 0.245 & 0.340 & 0.272 & 0.098 & 36 \\
\hline Octachlorosytrene & 1.02 & 1.15 & 1.07 & 1.21 & 1.21 & 1.13 & 0.083 & 7.4 \\
\hline Oxychlordane & 2.84 & 4.48 & 4.06 & 4.07 & 3.71 & 3.83 & 0.62 & 16 \\
\hline Pentachlorobenzene & 3.40 & 2.21 & 1.05 & 3.17 & 3.08 & 2.58 & 0.97 & 37 \\
\hline Mirex & 0.920 & 1.08 & 1.05 & 0.931 & 0.816 & 0.958 & 0.11 & 11 \\
\hline Cis-nonachlor & 0.840 & 1.04 & 0.563 & 1.02 & 0.867 & 0.867 & 0.19 & 22 \\
\hline Heptachlor epoxide & 2.42 & 3.15 & 2.51 & 2.84 & 2.70 & 2.72 & 0.29 & 11 \\
\hline
\end{tabular}


Appendix 17. Lipids (\%) and organochlorine pesticide mass fractions ( $\mathrm{ng} \mathrm{g}^{-1}$ wet mass) in common murre eggs collected at St. Lazaria Island Alaska in 2008.

\begin{tabular}{lllllllll}
\hline Compound & $\mathbf{1 2 3 4}$ & $\mathbf{1 2 3 5}$ & $\mathbf{1 2 3 6}$ & $\mathbf{1 2 3 8}$ & $\mathbf{1 2 4 0}$ & Mean & SD & RSD \\
\% Lipid & 8.86 & 8.24 & 8.11 & 9.52 & 10.0 & $\mathbf{8 . 9 5}$ & 0.82 & 9.2
\end{tabular}

\begin{tabular}{lllllllll}
$4,4 '-D D E$ & 99.9 & 77.3 & 124 & 303 & 115 & $\mathbf{1 4 4}$ & 91 & 63 \\
$4,4 '-D D T$ & $<$ LOQ & $<$ LOQ & 0.173 & 0.168 & 0.246 & $\mathbf{0 . 1 9 6}$ & 0.044 & 23 \\
HCB & 24.7 & 19.5 & 30.0 & 28.6 & 21.5 & $\mathbf{2 4 . 9}$ & 4.5 & 18 \\
$\alpha$-HCH & 0.478 & 0.815 & 1.38 & 0.966 & 1.66 & $\mathbf{1 . 0 6}$ & 0.47 & 44 \\
$\beta$-HCH & 12.2 & 6.75 & 11.1 & 14.7 & 21.1 & $\mathbf{1 3 . 2}$ & 5.3 & 40 \\
& & & & & & & & \\
Octachlorosytrene & 0.672 & 0.546 & 0.791 & 1.10 & 0.882 & $\mathbf{0 . 7 9 9}$ & 0.21 & 27 \\
Oxychlordane & 4.21 & 2.31 & 4.02 & 6.72 & 5.01 & $\mathbf{4 . 4 5}$ & 1.6 & 36 \\
Pentachlorobenzene & 0.564 & 0.499 & 0.783 & 0.774 & 0.653 & $\mathbf{0 . 6 5 5}$ & 0.13 & 19 \\
Mirex & 0.998 & 0.626 & 0.984 & 2.20 & 1.61 & $\mathbf{1 . 2 8}$ & 0.62 & 48 \\
Cis-chlordane & 0.211 & 0.154 & 0.201 & 0.248 & 0.511 & $\mathbf{0 . 2 6 5}$ & 0.14 & 53 \\
Cis-nonachlor & 0.967 & 0.268 & 0.483 & 1.15 & 7.90 & $\mathbf{2 . 1 5}$ & 3.2 & 150 \\
& & & & & & & & \\
Trans-nonachlor & 0.118 & $<$ LOD & $<$ LOD & 0.107 & 3.08 & $\mathbf{1 . 1 0}$ & 1.7 & 160 \\
Heptachlor epoxide & 2.17 & 0.913 & 1.29 & 2.57 & 5.76 & $\mathbf{2 . 5 4}$ & 1.9 & 76 \\
\hline
\end{tabular}


Appendix 18. Lipids (\%) and organochlorine pesticide mass fractions ( $\mathrm{ng} \mathrm{g}^{-1}$ wet mass) in thick-billed murre eggs collected at St. Lazaria Island Alaska in 2008.

\begin{tabular}{lllllllll}
\hline Compound & $\mathbf{1 2 4 2}$ & $\mathbf{1 2 4 3}$ & $\mathbf{1 2 4 4}$ & $\mathbf{1 2 4 5}$ & $\mathbf{1 2 4 6}$ & Mean & SD & RSD \\
\% Lipid & 9.92 & 8.98 & 9.98 & 9.30 & 8.46 & $\mathbf{9 . 3 3}$ & 0.64 & 6.9 \\
& & & & & & & & \\
& & & & & & & & \\
& & & & & & & & \\
- & & & & & & & & \\
4,4 '-DDE & 144 & 192 & 112 & 103 & 139 & $\mathbf{1 3 8}$ & 35 & 25 \\
4,4 '-DDT & $<$ LOQ & $<$ LOQ & $<$ LOQ & 0.172 & 0.146 & $\mathbf{0 . 1 5 9}$ & 0.018 & 11 \\
HCB & 27.1 & 24.3 & 26.6 & 28.6 & 23.7 & $\mathbf{2 6 . 1}$ & 2.1 & 7.9 \\
$\alpha-H C H$ & 0.644 & 0.300 & 0.547 & 0.869 & 0.561 & $\mathbf{0 . 5 8 4}$ & 0.20 & 35 \\
$\beta$-HCH & 9.44 & 6.00 & 11.1 & 14.0 & 9.24 & $\mathbf{9 . 9 6}$ & 2.9 & 29 \\
& & & & & & & & \\
Octachlorosytrene & 0.841 & 1.03 & 0.856 & 0.772 & 0.970 & $\mathbf{0 . 8 9 5}$ & 0.11 & 12 \\
Oxychlordane & 3.40 & 2.60 & 3.19 & 3.81 & 2.76 & $\mathbf{3 . 1 5}$ & 0.49 & 15 \\
Pentachlorobenzene & 0.655 & 0.492 & 0.921 & 1.03 & 0.771 & $\mathbf{0 . 7 7 4}$ & 0.21 & 28 \\
Mirex & 1.42 & 1.50 & 1.01 & 1.17 & 1.34 & $\mathbf{1 . 2 9}$ & 0.20 & 15 \\
Cis-chlordane & $<$ LOQ & $<$ LOQ & $<$ LOQ & 0.248 & 0.224 & $\mathbf{0 . 2 3 6}$ & 0.017 & 7.0 \\
Cis-nonachlor & 0.494 & 0.165 & 0.0766 & 0.854 & 0.532 & $\mathbf{0 . 4 2 4}$ & 0.31 & 74 \\
& & & & & & & & \\
Trans-nonachlor & $<$ LOD & $<$ LOD & $<$ LOD & 0.115 & 0.0768 & $\mathbf{0 . 0 9 6 0}$ & 0.027 & 28 \\
Heptachlor epoxide & 1.02 & 0.803 & 1.57 & 2.18 & 1.06 & $\mathbf{1 . 3 3}$ & 0.55 & 42 \\
\hline
\end{tabular}


Appendix 19. Lipids (\%) and organochlorine pesticide mass fractions (ng $\mathrm{g}^{-1}$ wet mass) in glaucous gull eggs collected at the Kukpuk River delta, Alaska in 2008.

\begin{tabular}{lllllllll}
\hline Compound & $\mathbf{1 3 4 9}$ & $\mathbf{1 3 5 1}$ & $\mathbf{1 3 5 4}$ & $\mathbf{1 3 5 7}$ & $\mathbf{1 3 5 8}$ & Mean & SD & RSD \\
\% Lipid & 5.22 & 6.76 & 6.99 & 5.41 & 6.22 & $\mathbf{6 . 0 9}$ & 0.91 & 15 \\
& & & & & & & & \\
& & & & & & & & \\
2,4'-DDT & $<$ LOD & 0.325 & 0.209 & $<$ LOD & $<$ LOD & $\mathbf{0 . 2 6 7}$ & 0.083 & 31 \\
4,4, '-DDD & 0.109 & 0.453 & 0.474 & 0.110 & 0.133 & $\mathbf{0 . 2 5 6}$ & 0.19 & 74 \\
4,4 '-DDE & 75.5 & 277 & 326 & 69.2 & 80.6 & $\mathbf{1 6 6}$ & 130 & 76 \\
$4,4 '$-DDT & 1.21 & 8.75 & 9.25 & 1.14 & 1.25 & $\mathbf{4 . 3 2}$ & 4.3 & 99 \\
HCB & 36.2 & 84.6 & 90.0 & 32.3 & 37.4 & $\mathbf{5 6 . 1}$ & 29 & 51 \\
$\alpha$-HCH & 0.217 & 0.222 & 0.185 & 0.174 & 0.245 & $\mathbf{0 . 2 0 9}$ & 0.029 & 14 \\
$\beta$-HCH & 15.2 & 41.0 & 45.8 & 15.2 & 17.0 & $\mathbf{2 6 . 8}$ & 15 & 57 \\
& & & & & & & & \\
Octachlorosytrene & 0.418 & 0.898 & 0.941 & 0.439 & 0.446 & $\mathbf{0 . 6 2 9}$ & 0.27 & 42 \\
Oxychlordane & 18.1 & 72.2 & 79.5 & 17.3 & 19.3 & $\mathbf{4 1 . 3}$ & 32 & 77 \\
Pentachlorobenzene & 0.848 & 2.34 & 1.68 & 0.610 & 0.992 & $\mathbf{1 . 2 9}$ & 0.71 & 55 \\
Mirex & 3.07 & 8.84 & 9.36 & 2.89 & 3.24 & $\mathbf{5 . 4 8}$ & 3.3 & 60 \\
Cis-chlordane & 0.405 & 1.07 & 1.13 & 0.387 & 0.371 & $\mathbf{0 . 6 7 3}$ & 0.39 & 58 \\
Cis-nonachlor & 1.10 & 9.41 & 10.5 & 1.03 & 1.18 & $\mathbf{4 . 6 5}$ & 4.9 & 110 \\
Trans-chlordane & 0.526 & 1.88 & 2.14 & 0.518 & 0.568 & $\mathbf{1 . 1 3}$ & 0.81 & 72 \\
Trans-nonachlor & 3.55 & 46.5 & 49.6 & 3.32 & 3.92 & $\mathbf{2 1 . 4}$ & 24 & 110 \\
Heptachlor epoxide & 3.82 & 9.37 & 10.5 & 3.60 & 4.27 & $\mathbf{6 . 3 1}$ & 3.3 & 53 \\
\hline & & & & & & & & \\
\hline
\end{tabular}


Appendix 20. Lipids (\%) and organochlorine pesticide mass fractions (ng $\mathrm{g}^{-1}$ wet mass) in glaucous gull eggs collected at Shishmaref Inlet Alaska in 2008.

\begin{tabular}{lllllllll}
\hline Compound & $\mathbf{1 4 0 7}$ & $\mathbf{1 4 1 1}$ & $\mathbf{1 4 1 4}$ & $\mathbf{1 4 1 5}$ & $\mathbf{1 4 1 6}$ & Mean & SD & RSD \\
\% Lipid & 7.42 & 6.79 & 6.31 & 6.37 & 7.49 & $\mathbf{6 . 7 2}$ & 0.51 & 7.7 \\
& & & & & & & & \\
& & & & & & & & \\
& & & & & & & & \\
$4,4, '-D D D$ & 1.31 & 0.501 & 0.573 & 0.713 & 0.328 & $\mathbf{0 . 6 8 5}$ & 0.38 & 55 \\
4,4 -DDE & 122 & 163 & 101 & 148 & 151 & $\mathbf{1 3 7}$ & 25 & 18 \\
4,4 -DDT & 3.86 & 4.63 & 1.63 & 7.80 & 4.47 & $\mathbf{4 . 4 8}$ & 2.2 & 49 \\
HCB & 45.1 & 48.0 & 36.7 & 44.2 & 55.8 & $\mathbf{4 6 . 0}$ & 6.9 & 15 \\
& & & & & & & & \\
$\beta$-HCH & 16.7 & 19.3 & 16.8 & 16.7 & 23.9 & $\mathbf{1 8 . 7}$ & 3.1 & 17 \\
& & & & & & & & \\
Octachlorosytrene & 0.680 & 0.914 & 0.627 & 0.877 & 0.697 & $\mathbf{0 . 7 5 9}$ & 0.13 & 17 \\
Oxychlordane & 15.1 & 22.6 & 24.0 & 23.6 & 17.7 & $\mathbf{2 0 . 6}$ & 4.0 & 19 \\
Pentachlorobenzene & 1.36 & 1.66 & 0.715 & 1.21 & 1.93 & $\mathbf{1 . 3 8}$ & 0.46 & 34 \\
Mirex & 3.19 & 4.02 & 4.04 & 4.09 & 3.48 & $\mathbf{3 . 7 7}$ & 0.41 & 11 \\
Cis-chlordane & 0.420 & 0.803 & 0.567 & 1.68 & 0.356 & $\mathbf{0 . 7 6 6}$ & 0.54 & 71 \\
Cis-nonachlor & 2.39 & 3.05 & 1.64 & 2.63 & 2.42 & $\mathbf{2 . 4 3}$ & 0.51 & 21 \\
Trans-chlordane & 1.62 & 2.61 & 1.72 & 2.18 & 2.11 & $\mathbf{2 . 0 5}$ & 0.39 & 19 \\
Trans-nonachlor & 4.61 & 7.72 & 6.61 & 6.85 & 5.39 & $\mathbf{6 . 2 4}$ & 1.2 & 20 \\
Heptachlor epoxide & 4.26 & 5.50 & 4.45 & 4.71 & 5.68 & $\mathbf{4 . 9 2}$ & 0.64 & 13 \\
\hline
\end{tabular}


Appendix 21. Lipids (\%) and organochlorine pesticide mass fractions (ng $\mathrm{g}^{-1}$ wet mass) in glaucous gull eggs collected at Brevig Mission Alaska, in 2009.

\begin{tabular}{lllllllll}
\hline Compound & $\mathbf{1 4 3 3}$ & $\mathbf{1 4 3 5}$ & $\mathbf{1 4 3 6}$ & $\mathbf{1 4 3 9}$ & $\mathbf{1 4 4 1}$ & Mean & SD & RSD \\
\% Lipid & 4.89 & 4.46 & 5.40 & 5.75 & 6.74 & $\mathbf{5 . 4 5}$ & 0.87 & 16 \\
& & & & & & & & \\
& & & & & & & & \\
& & & & & & & & \\
$4,4, '-D D D$ & 0.0998 & 0.313 & 0.392 & 1.96 & 0.0787 & $\mathbf{0 . 5 6 9}$ & 0.79 & 140 \\
4,4 -DDE & 165 & 88.7 & 237 & 286 & 177 & $\mathbf{1 9 1}$ & 75 & 39 \\
4,4 '-DDT & 0.591 & 3.95 & 2.22 & 3.37 & 0.691 & $\mathbf{2 . 1 6}$ & 1.5 & 70 \\
HCB & 44.4 & 23.5 & 58.8 & 49.3 & 67.3 & $\mathbf{4 8 . 7}$ & 17 & 34 \\
& & & & & & & & \\
$\beta$-HCH & 24.3 & 10.2 & 33.4 & 24.9 & 31.2 & $\mathbf{2 4 . 8}$ & 9.1 & 37 \\
& & & & & & & & \\
Octachlorosytrene & 0.755 & 0.517 & 0.877 & 0.924 & 1.16 & $\mathbf{0 . 8 4 6}$ & 0.24 & 28 \\
Oxychlordane & 32.0 & 14.5 & 46.1 & 34.1 & 33.3 & $\mathbf{3 2 . 0}$ & 11 & 35 \\
Pentachlorobenzene & 2.38 & 2.22 & 3.68 & 2.66 & 3.74 & $\mathbf{2 . 9 4}$ & 0.73 & 25 \\
Mirex & 5.48 & 2.31 & 5.42 & 8.22 & 5.83 & $\mathbf{5 . 4 5}$ & 2.1 & 39 \\
Cis-chlordane & 0.362 & 0.518 & 0.563 & 1.73 & 0.305 & $\mathbf{0 . 6 9 6}$ & 0.59 & 85 \\
Cis-nonachlor & 1.47 & 1.50 & 3.97 & 6.30 & 2.63 & $\mathbf{3 . 1 7}$ & 2.0 & 64 \\
Trans-chlordane & 1.83 & 1.01 & 2.41 & 2.02 & 2.97 & $\mathbf{2 . 0 5}$ & 0.72 & 35 \\
Trans-nonachlor & 3.89 & 2.48 & 11.5 & 37.9 & 5.30 & $\mathbf{1 2 . 2}$ & 15 & 120 \\
Heptachlor epoxide & 8.54 & 3.58 & 12.6 & 11.4 & 10.8 & $\mathbf{9 . 3 8}$ & 3.6 & 38 \\
\hline
\end{tabular}


Appendix 22. Lipids (\%) and organochlorine pesticide mass fractions (ng $\mathrm{g}^{-1}$ wet mass) in glaucous gull eggs collected at the Sinuk River delta, Alaska in 2008.

\begin{tabular}{|c|c|c|c|c|c|c|c|c|c|c|c|}
\hline Compound & 1339 & 1340 & 1340-2 & 1340 Mean & $\%$ difference & 1343 & 1344 & 1345 & Mean & SD & RSD \\
\hline \% Lipid & 7.23 & - & 7.04 & - & - & 7.45 & 7.22 & 6.32 & 7.24 & 0.17 & 2.4 \\
\hline 4,4,'-DDD & 0.328 & 0.405 & 0.413 & 0.409 & -1.9 & 0.105 & 0.419 & 0.231 & 0.298 & 0.13 & 44 \\
\hline 4,4'-DDE & 141 & 93.8 & 89.1 & 91.4 & 5.1 & 76.6 & 156 & 93.9 & 112 & 35 & 31 \\
\hline 4,4'-DDT & 4.73 & 6.43 & 6.14 & 6.28 & 4.6 & 1.77 & 4.70 & 3.10 & 4.12 & 1.7 & 42 \\
\hline $\mathrm{HCB}$ & 36.8 & 26.3 & 26.7 & 26.5 & -1.4 & 43.1 & 45.6 & 29.8 & 36.4 & 8.2 & 23 \\
\hline$\beta-\mathrm{HCH}$ & 12.0 & 8.13 & 7.54 & 7.84 & 7.6 & 24.4 & 18.1 & 8.89 & 14.2 & 6.9 & 49 \\
\hline Octachlorosytrene & 0.912 & 0.677 & 0.672 & 0.674 & 0.75 & 0.614 & 0.702 & 0.704 & 0.721 & 0.11 & 16 \\
\hline Oxychlordane & 17.6 & 14.2 & 13.6 & 13.9 & 4.3 & 25.2 & 21.5 & 9.92 & 17.6 & 6.0 & 34 \\
\hline Pentachlorobenzene & 0.738 & 0.719 & 0.778 & 0.749 & -8.0 & 0.956 & 0.880 & 0.213 & 0.707 & 0.29 & 41 \\
\hline Mirex & 3.51 & 2.67 & 2.59 & 2.63 & 2.9 & 3.92 & 5.11 & 2.00 & 3.43 & 1.2 & 35 \\
\hline Cis-chlordane & 0.449 & 1.05 & 1.06 & 1.06 & -1.0 & 0.202 & 0.637 & 0.605 & 0.590 & 0.31 & 53 \\
\hline Cis-nonachlor & 3.12 & 2.45 & 2.39 & 2.42 & 2.3 & 1.41 & 1.97 & 1.66 & 2.12 & 0.68 & 32 \\
\hline Trans-chlordane & 1.76 & 1.23 & 1.16 & 1.20 & 5.5 & 0.972 & 1.44 & 1.45 & 1.36 & 0.30 & 22 \\
\hline Trans-nonachlor & 4.61 & 6.76 & 6.46 & 6.61 & 4.6 & 1.59 & 3.56 & 4.66 & 4.21 & 1.8 & 44 \\
\hline Heptachlor epoxide & 3.69 & 3.12 & 3.09 & 3.11 & 0.70 & 4.91 & 5.06 & 3.21 & 4.00 & 0.93 & 23 \\
\hline
\end{tabular}


Appendix 23. Lipids (\%) and organochlorine pesticide mass fractions ( $\mathrm{ng} \mathrm{g}^{-1}$ wet mass) in glaucous gull eggs collected at Safety Sound, Alaska in 2008. Egg 1367 is believed to be a common eider.

\begin{tabular}{lllllllll}
\hline Compound & $\mathbf{1 3 6 5}$ & $\mathbf{1 3 6 7}$ & $\mathbf{1 3 6 8}$ & $\mathbf{1 3 6 9}$ & $\mathbf{1 3 7 0}$ & Mean & SD & RSD \\
\% Lipid & 6.07 & 4.95 & 3.88 & 3.27 & 5.44 & $\mathbf{4 . 5 4}$ & 1.2 & 27 \\
& & & & & & & & \\
& & & & & & & & \\
2,4'-DDT & 0.157 & $<$ LOD & $<$ LOD & $<$ LOD & 0.111 & $\mathbf{0 . 1 3 4}$ & 0.032 & 24 \\
$4,4, '-D D D$ & 0.274 & 0.0985 & 0.0709 & $<$ LOD & 0.312 & $\mathbf{0 . 1 8 9}$ & 0.12 & 64 \\
4,4'-DDE & 52.6 & 185 & 96.4 & 91.5 & 98.0 & $\mathbf{1 0 5}$ & 48 & 46 \\
4,4'-DDT & 0.932 & 0.195 & 3.24 & 0.387 & 3.31 & $\mathbf{1 . 6 1}$ & 1.5 & 96 \\
HCB & 34.2 & 65.3 & 37.1 & 40.5 & 31.1 & $\mathbf{4 1 . 6}$ & 14 & 33 \\
& & & & & & & & \\
B-HCH & 10.5 & 24.0 & 12.2 & 18.3 & 7.75 & $\mathbf{1 4 . 5}$ & 6.5 & 45 \\
& & & & & & & & \\
Octachlorosytrene & 0.628 & 1.15 & 0.750 & 0.713 & 0.690 & $\mathbf{0 . 7 8 6}$ & 0.21 & 26 \\
Oxychlordane & 10.7 & 34.6 & 12.9 & 13.6 & 20.3 & $\mathbf{1 8 . 4}$ & 9.7 & 53 \\
Pentachlorobenzene & 0.766 & 1.28 & 0.810 & 0.267 & 0.525 & $\mathbf{0 . 7 2 9}$ & 0.37 & 51 \\
Mirex & 2.25 & 7.49 & 3.19 & 2.34 & 2.61 & $\mathbf{3 . 5 7}$ & 2.2 & 62 \\
Cis-chlordane & 0.640 & 0.505 & 0.606 & 0.293 & 0.780 & $\mathbf{0 . 5 6 5}$ & 0.18 & 32 \\
Cis-nonachlor & 1.64 & 2.46 & 2.25 & 1.39 & 1.89 & $\mathbf{1 . 9 3}$ & 0.44 & 23 \\
Trans-chlordane & 1.27 & 1.52 & 1.63 & 1.16 & 0.887 & $\mathbf{1 . 2 9}$ & 0.30 & 23 \\
Trans-nonachlor & 4.13 & 3.40 & 6.13 & 2.43 & 2.53 & $\mathbf{3 . 7 3}$ & 1.5 & 41 \\
Heptachlor epoxide & 3.98 & 7.05 & 4.02 & 3.92 & 3.64 & $\mathbf{4 . 5 2}$ & 1.4 & 31 \\
\hline & & & & & & & & \\
\hline
\end{tabular}


Appendix 24. Lipids (\%) and organochlorine pesticide mass fractions ( $\mathrm{ng} \mathrm{g}^{-1}$ wet mass) in glaucous gull eggs collected at Bluff, Alaska in 2008.

\begin{tabular}{llllllll}
\hline Compound & $\mathbf{1 3 8 4}$ & $\mathbf{1 3 8 5}$ & $\mathbf{1 3 8 8}$ & $\mathbf{1 3 8 9}$ & Mean & SD & RSD \\
\% Lipid & 6.65 & 6.51 & 6.95 & 6.65 & $\mathbf{6 . 6 9}$ & 0.19 & 2.8 \\
& & & & & & & \\
& & & & & & & \\
2,4'-DDT & 0.785 & $<$ LOD & $<$ LOD & 0.0723 & $\mathbf{0 . 4 2 9}$ & 0.50 & 120 \\
4,4, '-DDD & 0.423 & $<$ LOD & $<$ LOD & 0.471 & $\mathbf{0 . 4 4 7}$ & 0.034 & 7.6 \\
4,4'-DDE & 101 & 68.4 & 87.1 & 126 & $\mathbf{9 5 . 6}$ & 24 & 26 \\
4,4'-DDT & 5.30 & 0.448 & 0.563 & 3.03 & $\mathbf{2 . 3 3}$ & 2.3 & 99 \\
HCB & 34.0 & 29.5 & 35.7 & 43.5 & $\mathbf{3 5 . 7}$ & 5.8 & 16 \\
& & & & & & & \\
$\beta$-HCH & 16.0 & 8.16 & 10.3 & 14.1 & $\mathbf{1 2 . 1}$ & 3.6 & 29 \\
& & & & & & & \\
Octachlorosytrene & 0.589 & 0.684 & 0.855 & 0.672 & $\mathbf{0 . 7 0 0}$ & 0.11 & 16 \\
Oxychlordane & 23.4 & 11.8 & 13.8 & 20.9 & $\mathbf{1 7 . 5}$ & 5.6 & 32 \\
Pentachlorobenzene & 0.842 & 0.707 & 1.05 & 1.17 & $\mathbf{0 . 9 4 2}$ & 0.21 & 22 \\
Mirex & 3.40 & 2.08 & 2.78 & 4.74 & $\mathbf{3 . 2 5}$ & 1.1 & 35 \\
Cis-chlordane & 1.54 & 0.501 & 0.535 & 0.693 & $\mathbf{0 . 8 1 8}$ & 0.49 & 60 \\
Cis-nonachlor & 2.06 & 1.69 & 2.05 & 2.51 & $\mathbf{2 . 0 8}$ & 0.34 & 16 \\
Trans-chlordane & 1.07 & 1.35 & 1.76 & 1.45 & $\mathbf{1 . 4 1}$ & 0.29 & 20 \\
Trans-nonachlor & 3.49 & 4.01 & 4.85 & 8.73 & $\mathbf{5 . 2 7}$ & 2.4 & 45 \\
Heptachlor epoxide & 4.66 & 3.59 & 3.93 & 5.94 & $\mathbf{4 . 5 3}$ & 1.0 & 23 \\
\hline
\end{tabular}


Appendix 25. Lipids (\%) and organochlorine pesticide mass fractions ( $\mathrm{ng} \mathrm{g}^{-1}$ wet mass) in glaucous gull eggs collected at Carolyn Island, Alaska in 2008.

\begin{tabular}{|c|c|c|c|c|c|c|c|c|}
\hline Compound & 1390 & 1393 & 1394 & 1397 & 1398 & Mean & SD & RSD \\
\hline$\%$ Lipid & 7.65 & 5.53 & 5.20 & 6.84 & 5.35 & 6.30 & 1.1 & 18 \\
\hline 4,4,'-DDD & 0.152 & 0.326 & 0.342 & 0.185 & 0.197 & 0.240 & 0.087 & 36 \\
\hline 4,4'-DDE & 105 & 93.7 & 102 & 67.4 & 102 & 94.1 & 15 & 16 \\
\hline 4,4'-DDT & 0.403 & 4.07 & 5.34 & 2.95 & 3.98 & 3.35 & 1.9 & 55 \\
\hline $\mathrm{HCB}$ & 29.1 & 37.9 & 31.9 & 34.5 & 38.2 & 34.3 & 3.9 & 11 \\
\hline$\alpha-\mathrm{HCH}$ & 0.222 & $<\mathrm{LOQ}$ & $<\mathrm{LOQ}$ & 0.219 & $<\mathrm{LOQ}$ & 0.221 & 0.0022 & 0.99 \\
\hline$\beta-\mathrm{HCH}$ & 8.22 & 13.5 & 9.82 & 11.1 & 12.6 & 11.0 & 2.1 & 19 \\
\hline Octachlorosytrene & 0.629 & 0.675 & 0.895 & 0.690 & 0.758 & 0.729 & 0.10 & 14 \\
\hline Oxychlordane & 17.8 & 12.4 & 14.8 & 10.8 & 21.5 & 15.5 & 4.3 & 28 \\
\hline Pentachlorobenzene & 0.454 & 0.988 & 0.196 & 1.02 & 0.306 & 0.592 & 0.39 & 65 \\
\hline Mirex & 3.95 & 2.41 & 2.51 & 1.72 & 3.06 & 2.73 & 0.83 & 31 \\
\hline Cis-chlordane & 0.611 & 0.995 & 0.909 & 0.630 & 0.694 & 0.768 & 0.17 & 23 \\
\hline Cis-nonachlor & 2.35 & 2.52 & 3.35 & 2.37 & 2.68 & 2.65 & 0.41 & 16 \\
\hline Trans-chlordane & 1.17 & 1.92 & 1.81 & 1.37 & 1.45 & 1.54 & 0.31 & 20 \\
\hline Trans-nonachlor & 3.35 & 8.05 & 6.70 & 5.07 & 4.27 & 5.49 & 1.9 & 34 \\
\hline Heptachlor epoxide & 3.69 & 5.01 & 3.49 & 3.91 & 4.54 & 4.13 & 0.63 & 15 \\
\hline
\end{tabular}


Appendix 26. Lipids (\%) and organochlorine pesticide mass fractions ( $\mathrm{ng} \mathrm{g}^{-1}$ wet mass) in glaucous gull eggs collected at Cape Darby, Alaska in 2008.

\begin{tabular}{lllllllll}
\hline Compound & $\mathbf{1 3 7 1}$ & $\mathbf{1 3 7 4}$ & $\mathbf{1 3 7 7}$ & $\mathbf{1 3 7 9}$ & $\mathbf{1 3 8 0}$ & Mean & SD & RSD \\
\% Lipid & 5.65 & 6.04 & 5.30 & 5.33 & 5.84 & $\mathbf{5 . 5 8}$ & 0.34 & 6.2 \\
& & & & & & & & \\
& & & & & & & & \\
& & & & & & & & \\
$4,4, '$-DDD & 0.180 & 0.231 & 0.371 & 0.211 & 0.277 & $\mathbf{0 . 2 5 4}$ & 0.074 & 29 \\
4,4 '-DDE & 155 & 104 & 93.1 & 72.7 & 57.8 & $\mathbf{9 6 . 7}$ & 37 & 39 \\
4,4 '-DDT & 2.74 & 0.414 & 2.51 & 0.986 & 1.36 & $\mathbf{1 . 6 0}$ & 1.0 & 62 \\
HCB & 34.0 & 9.5 & 30.5 & 36.4 & 32.7 & $\mathbf{3 2 . 6}$ & 2.8 & 8.4 \\
$\alpha$-HCH & 0.182 & 0.209 & $<$ LOQ & 0.174 & $<$ LOQ & $\mathbf{0 . 1 8 8}$ & 0.019 & 9.9 \\
$\beta$-HCH & 11.7 & 8.36 & 10.3 & 11.1 & 10.7 & $\mathbf{1 0 . 4}$ & 1.3 & 12 \\
& & & & & & & & \\
Octachlorosytrene & 0.731 & 0.621 & 0.604 & 0.894 & 0.605 & $\mathbf{0 . 6 9 1}$ & 0.13 & 18 \\
Oxychlordane & 20.3 & 17.0 & 13.4 & 10.2 & 9.02 & $\mathbf{1 4 . 0}$ & 4.7 & 34 \\
Pentachlorobenzene & 0.640 & 0.458 & 0.571 & 0.656 & 0.679 & $\mathbf{0 . 6 0 1}$ & 0.089 & 15 \\
Mirex & 5.24 & 3.37 & 2.58 & 2.02 & 1.58 & $\mathbf{2 . 9 6}$ & 1.4 & 49 \\
Cis-chlordane & 1.01 & 0.769 & 0.458 & 0.497 & 0.407 & $\mathbf{0 . 6 2 9}$ & 0.26 & 41 \\
Cis-nonachlor & 2.95 & 2.27 & 1.40 & 2.61 & 1.57 & $\mathbf{2 . 1 6}$ & 0.66 & 31 \\
Trans-chlordane & 1.84 & 1.23 & 0.875 & 1.38 & 0.787 & $\mathbf{1 . 2 2}$ & 0.42 & 35 \\
Trans-nonachlor & 7.94 & 3.66 & 1.85 & 4.70 & 1.94 & $\mathbf{4 . 0 2}$ & 2.5 & 62 \\
Heptachlor epoxide & 4.57 & 3.95 & 3.61 & 3.50 & 3.34 & $\mathbf{3 . 7 9}$ & 0.49 & 13 \\
\hline & & & & & & & & \\
\hline
\end{tabular}


Appendix 27. Lipids (\%) and organochlorine pesticide mass fractions (ng $\mathrm{g}^{-1}$ wet mass) in glaucous gull eggs collected at Shaktoolik, Alaska in 2008.

\begin{tabular}{|c|c|c|c|c|c|c|c|c|c|c|}
\hline Compound & 1401 & 1402 & 1403 & $1403-2$ & 1403 Mean & $\%$ difference & 1404 & Mean & SD & RSD \\
\hline \% Lipid & 6.24 & 6.34 & 5.52 & 5.49 & 5.50 & 0.55 & 6.58 & 6.39 & 0.18 & 2.8 \\
\hline 4,4,'-DDD & 0.175 & 0.207 & 0.244 & 0.257 & 0.251 & -5.4 & 0.115 & 0.187 & 0.057 & 31 \\
\hline 4,4'-DDE & 64.8 & 72.5 & 106 & 109 & 107 & -3.0 & 149 & 98.5 & 39 & 39 \\
\hline 4,4'-DDT & 2.24 & 2.38 & 2.94 & 2.98 & 2.96 & -1.5 & 1.04 & 2.15 & 0.81 & 37 \\
\hline $\mathrm{HCB}$ & 34.6 & 44.5 & 49.0 & 49.8 & 49.4 & -1.5 & 64.6 & 48.3 & 13 & 26 \\
\hline$\beta-\mathrm{HCH}$ & 14.4 & 15.5 & 15.6 & 15.1 & 15.3 & 3.1 & 21.7 & 16.7 & 3.4 & 20 \\
\hline Octachlorosytrene & 0.699 & 0.768 & 0.881 & 0.894 & 0.888 & -1.5 & 1.15 & 0.877 & 0.20 & 23 \\
\hline Oxychlordane & 15.6 & 20.4 & 17.7 & 17.3 & 17.5 & 2.2 & 17.0 & 17.6 & 2.0 & 11 \\
\hline Pentachlorobenzene & 0.801 & 1.07 & 1.17 & 1.12 & 1.14 & 4.4 & 1.66 & 1.17 & 0.36 & 31 \\
\hline Mirex & 2.73 & 4.30 & 3.89 & 3.95 & 3.92 & -1.6 & 4.55 & 3.88 & 0.81 & 21 \\
\hline Cis-chlordane & 0.336 & 1.48 & 0.362 & 0.369 & 0.365 & -1.9 & 0.508 & 0.671 & 0.54 & 81 \\
\hline Cis-nonachlor & 1.70 & 2.39 & 2.41 & 2.32 & 2.37 & 3.9 & 4.26 & 2.68 & 1.1 & 41 \\
\hline Trans-chlordane & 1.15 & 1.76 & 1.70 & 1.75 & 1.73 & -3.2 & 3.53 & 2.04 & 1.0 & 51 \\
\hline Trans-nonachlor & 4.36 & 7.56 & 3.76 & 3.82 & 3.79 & -1.6 & 13.9 & 7.41 & 4.7 & 63 \\
\hline Heptachlor epoxide & 5.05 & 5.24 & 4.89 & 4.86 & 4.88 & 0.56 & 6.34 & 5.38 & 0.66 & 12 \\
\hline
\end{tabular}


Appendix 28. Lipids (\%) and organochlorine pesticide mass fractions (ng $\mathrm{g}^{-1}$ wet mass) in glaucous gull eggs collected at Shaktoolik, Alaska in 2009.

\begin{tabular}{lllllllll}
\hline Compound & $\mathbf{1 4 2 4}$ & $\mathbf{1 4 2 6}$ & $\mathbf{1 4 2 7}$ & $\mathbf{1 4 2 8}$ & $\mathbf{1 4 2 9}$ & Mean & SD & RSD \\
\% Lipid & 5.84 & 6.17 & 6.29 & 6.29 & 6.47 & $\mathbf{6 . 2 1}$ & 0.23 & 3.7 \\
& & & & & & & & \\
& & & & & & & & \\
& & & & & & & & \\
$4,4, '-D D D$ & 1.10 & 0.108 & 0.146 & 3.28 & 0.496 & $\mathbf{1 . 0 3}$ & 1.3 & 130 \\
4,4 -DDE & 134 & 91.7 & 90.4 & 158 & 105 & $\mathbf{1 1 6}$ & 29 & 25 \\
4,4 '-DDT & 3.89 & 0.963 & 1.82 & 0.861 & 1.76 & $\mathbf{1 . 8 6}$ & 1.2 & 65 \\
HCB & 44.7 & 39.0 & 32.4 & 43.6 & 43.1 & $\mathbf{4 0 . 6}$ & 5.1 & 13 \\
& & & & & & & & \\
$\beta$-HCH & 18.4 & 15.2 & 11.5 & 4.90 & 15.4 & $\mathbf{1 3 . 1}$ & 5.2 & 40 \\
& & & & & & & & \\
Octachlorosytrene & 0.803 & 0.617 & 0.634 & 0.773 & 0.957 & $\mathbf{0 . 7 5 7}$ & 0.14 & 18 \\
Oxychlordane & 26.2 & 24.8 & 12.6 & 35.5 & 22.1 & $\mathbf{2 4 . 2}$ & 8.2 & 34 \\
Pentachlorobenzene & 4.57 & 2.40 & 2.89 & 4.28 & 3.23 & $\mathbf{3 . 4 7}$ & 0.93 & 27 \\
Mirex & 3.19 & 3.25 & 1.82 & 5.09 & 3.28 & $\mathbf{3 . 3 3}$ & 1.2 & 35 \\
Cis-chlordane & 0.618 & 0.269 & 0.294 & 0.482 & 0.457 & $\mathbf{0 . 4 2 4}$ & 0.14 & 34 \\
Cis-nonachlor & 2.91 & 0.962 & 1.61 & 2.03 & 2.33 & $\mathbf{1 . 9 7}$ & 0.74 & 37 \\
Trans-chlordane & 2.17 & 0.843 & 1.69 & 1.53 & 1.52 & $\mathbf{1 . 5 5}$ & 0.47 & 31 \\
Trans-nonachlor & 14.3 & 1.88 & 3.63 & 5.41 & 3.41 & $\mathbf{5 . 7 3}$ & 5.0 & 87 \\
Heptachlor epoxide & 7.27 & 5.89 & 3.90 & 7.90 & 5.66 & $\mathbf{6 . 1 3}$ & 1.6 & 25 \\
\hline
\end{tabular}


Appendix 29. Lipids (\%) and organochlorine pesticide mass fractions (ng $\mathrm{g}^{-1}$ wet mass) in glaucous gull eggs collected at Stuart Island, Alaska in 2009.

\begin{tabular}{lllllllll}
\hline Compound & $\mathbf{1 4 1 9}$ & $\mathbf{1 4 2 0}$ & $\mathbf{1 4 2 1}$ & $\mathbf{1 4 2 2}$ & $\mathbf{1 4 2 3}$ & Mean & SD & RSD \\
\% Lipid & 6.87 & 5.62 & 6.35 & 5.38 & 6.40 & $\mathbf{6 . 1 2}$ & 0.61 & 10 \\
& & & & & & & & \\
& & & & & & & & \\
& & & & & & & & \\
$4,4, '$-DDD & 0.106 & 0.265 & 0.116 & 0.193 & 1.25 & $\mathbf{0 . 3 8 6}$ & 0.49 & 130 \\
4,4 -DDE & 83.9 & 391 & 64.9 & 356 & 113 & $\mathbf{2 0 2}$ & 160 & 78 \\
4,4'-DDT & 0.676 & 4.06 & 0.519 & 3.98 & 5.34 & $\mathbf{2 . 9 2}$ & 2.2 & 75 \\
HCB & 10.9 & 39.1 & 8.42 & 37.3 & 41.5 & $\mathbf{2 7 . 4}$ & 16 & 60 \\
& & & & & & & & \\
$\beta$-HCH & 4.77 & 23.4 & 3.45 & 20.8 & 15.8 & $\mathbf{1 3 . 7}$ & 9.2 & 67 \\
& & & & & & & & \\
Octachlorosytrene & 0.278 & 0.877 & 0.214 & 0.843 & 0.729 & $\mathbf{0 . 5 8 8}$ & 0.32 & 54 \\
Oxychlordane & 1.49 & 39.4 & 1.19 & 36.3 & 21.2 & $\mathbf{1 9 . 9}$ & 18 & 92 \\
Pentachlorobenzene & 1.29 & 2.67 & 0.819 & 2.86 & 2.78 & $\mathbf{2 . 0 8}$ & 0.96 & 46 \\
Mirex & 0.492 & 8.34 & 0.362 & 7.85 & 2.54 & $\mathbf{3 . 9 2}$ & 3.9 & 100 \\
Cis-chlordane & 0.389 & 0.351 & 0.359 & 0.382 & 0.629 & $\mathbf{0 . 4 2 2}$ & 0.12 & 28 \\
Cis-nonachlor & 0.938 & 3.28 & 0.715 & 2.89 & 2.26 & $\mathbf{2 . 0 2}$ & 1.1 & 57 \\
Trans-chlordane & 0.847 & 2.19 & 0.583 & 1.92 & 2.62 & $\mathbf{1 . 6 3}$ & 0.88 & 54 \\
Trans-nonachlor & 4.08 & 7.53 & 3.15 & 7.02 & 5.57 & $\mathbf{5 . 4 7}$ & 1.9 & 34 \\
Heptachlor epoxide & 1.53 & 7.78 & 1.34 & 7.28 & 6.26 & $\mathbf{4 . 8 4}$ & 3.2 & 65 \\
\hline & & & & & & & &
\end{tabular}


Appendix 30. Lipids (\%) and organochlorine pesticide mass fractions ( $\mathrm{ng} \mathrm{g}^{-1}$ wet mass) in glaucous-winged gull eggs collected at Aiktak Island, Alaska in 2009.

\begin{tabular}{|c|c|c|c|c|c|c|c|c|}
\hline Compound & 1473 & 1474 & 1475 & 1477 & 1478 & Mean & SD & RSD \\
\hline \% Lipid & 7.03 & 6.20 & 6.51 & 7.32 & 7.17 & 6.85 & 0.47 & 6.8 \\
\hline 4,4,'-DDD & 0.0886 & $<\mathrm{LOD}$ & $<\mathrm{LOD}$ & 0.328 & 0.0883 & 0.168 & 0.14 & 82 \\
\hline 4,4'-DDE & 17.5 & 324 & 39.8 & 84.4 & 98.4 & 113 & 120 & 110 \\
\hline 4,4'-DDT & 0.125 & $<\mathrm{LOD}$ & 0.256 & 0.218 & 0.134 & 0.183 & 0.064 & 35 \\
\hline $\mathrm{HCB}$ & 6.38 & 21.6 & 25.4 & 28.0 & 20.4 & 20.3 & 8.4 & 41 \\
\hline$\beta-\mathrm{HCH}$ & 4.36 & 25.2 & 13.9 & 14.7 & 11.5 & 13.9 & 7.5 & 54 \\
\hline Octachlorosytrene & 0.144 & 0.699 & 0.443 & 0.396 & 0.456 & 0.428 & 0.20 & 46 \\
\hline Oxychlordane & 3.59 & 29.8 & 9.06 & 17.3 & 13.6 & 14.7 & 9.9 & 67 \\
\hline Pentachlorobenzene & 0.592 & 1.74 & 1.64 & 1.45 & 0.749 & 1.24 & 0.53 & 43 \\
\hline Mirex & 0.718 & 8.46 & 2.17 & 4.24 & 4.03 & 3.93 & 2.9 & 74 \\
\hline Cis-chlordane & 0.334 & 0.556 & 0.557 & 0.516 & 0.314 & 0.456 & 0.12 & 27 \\
\hline Cis-nonachlor & 0.803 & 1.51 & 1.92 & 1.11 & 1.03 & 1.28 & 0.44 & 35 \\
\hline Trans-chlordane & 0.141 & 1.60 & 1.00 & 0.571 & 0.946 & 0.851 & 0.54 & 64 \\
\hline Trans-nonachlor & 1.03 & 3.06 & 3.04 & 1.23 & 1.06 & 1.89 & 1.1 & 57 \\
\hline Heptachlor epoxide & 2.59 & 7.51 & 4.33 & 5.74 & 4.41 & 4.91 & 1.8 & 37 \\
\hline
\end{tabular}


Appendix 31. Brominated diphenyl ether (BDE) and polychlorinated biphenyl (PCB) mass fractions (ng g ${ }^{-1}$ wet mass) in unidentified murre eggs collected at Cape Lisburne, Alaska in 2009 (compounds shown in red and blue were above and below reference value ranges, respectively).

\begin{tabular}{|c|c|c|c|c|c|c|c|c|}
\hline Compound & 1454 & 1455 & 1457 & 1458 & 1460 & Mean & SD & RSD \\
\hline BDE47 & $<$ LOQ & 0.267 & 0.556 & 0.306 & 0.193 & 0.331 & 0.16 & 48 \\
\hline BDE99 & $<\mathrm{LOQ}$ & $<\mathrm{LOQ}$ & 0.0902 & $<\mathrm{LOQ}$ & $<$ LOQ & $<\mathrm{LOQ}$ & & \\
\hline BDE100 & $<\mathrm{LOD}$ & 0.150 & 0.169 & 0.164 & 0.100 & 0.146 & 0.032 & 22 \\
\hline PCB 8 & $<\mathrm{LOD}$ & $<\mathrm{LOD}$ & $<\mathrm{LOD}$ & $<\mathrm{LOD}$ & $<\mathrm{LOD}$ & $<$ LOD & & \\
\hline PCB 18 & $<\mathrm{LOD}$ & $<\mathrm{LOD}$ & $<\mathrm{LOD}$ & $<\mathrm{LOD}$ & $<\mathrm{LOD}$ & $<$ LOD & & \\
\hline PCB28+31 & 1.94 & 3.50 & 2.50 & 2.79 & 1.81 & 2.51 & 0.68 & 27 \\
\hline PCB 29 & $<\mathrm{LOD}$ & $<\mathrm{LOD}$ & $<\mathrm{LOD}$ & $<\mathrm{LOD}$ & $<$ LOD & $<$ LOD & & \\
\hline PCB 44 & $<\mathrm{LOQ}$ & $<\mathrm{LOQ}$ & $<\mathrm{LOQ}$ & $<\mathrm{LOQ}$ & $<$ LOQ & $<\mathbf{L O Q}$ & & \\
\hline PCB 45 & $<\mathrm{LOQ}$ & $<\mathrm{LOQ}$ & $<\mathrm{LOQ}$ & $<$ LOQ & $<$ LOQ & $<\mathbf{L O Q}$ & & \\
\hline PCB 49 & 0.0336 & 0.0679 & 0.0432 & 0.0405 & 0.0463 & 0.0463 & 0.013 & 28 \\
\hline PCB 52 & 0.0999 & 0.197 & 0.147 & 0.136 & 0.141 & 0.144 & 0.035 & 24 \\
\hline PCB 56 & $<\mathrm{LOQ}$ & 0.178 & 0.152 & 0.191 & 0.185 & 0.176 & 0.017 & 9.7 \\
\hline РCB 63 & 0.106 & 0.182 & 0.150 & 0.211 & 0.152 & 0.160 & 0.039 & 25 \\
\hline PCB 66 & 1.50 & 2.20 & 1.64 & 2.01 & 1.49 & 1.77 & 0.32 & 18 \\
\hline PCB 70 & 0.0494 & 2.07 & 0.0527 & 0.0482 & 0.0573 & 0.456 & 0.90 & 200 \\
\hline PCB 74 & 1.04 & 1.76 & 1.23 & 1.59 & 1.13 & 1.35 & 0.31 & 23 \\
\hline PCB 79 & $<\mathrm{LOQ}$ & $<\mathrm{LOQ}$ & $<$ LOQ & $<\mathrm{LOQ}$ & $<\mathrm{LOQ}$ & $<\mathrm{LOQ}$ & & \\
\hline PCB 82 & $<\mathrm{LOQ}$ & 0.0309 & 0.0291 & 0.0401 & 0.0296 & 0.0324 & 0.0052 & 16 \\
\hline PCB 87 & 0.0491 & 0.159 & 0.0950 & 0.166 & 0.105 & 0.115 & 0.048 & 42 \\
\hline РCB 92 & 0.0812 & 0.0965 & 0.0833 & 0.0915 & 0.0847 & 0.0874 & 0.0064 & 7.3 \\
\hline PCB 95+121 & $<\mathrm{LOD}$ & 0.0568 & 0.0199 & $<\mathrm{LOD}$ & $<\mathrm{LOD}$ & 0.0383 & 0.026 & 68 \\
\hline PCB 99 & 1.88 & 7.71 & 3.97 & 4.38 & 3.86 & 4.36 & 2.1 & 48 \\
\hline PCB 101 & 0.142 & 0.248 & 0.162 & 0.345 & 0.188 & 0.217 & 0.082 & 38 \\
\hline PCB 105 & 1.32 & 2.03 & 1.33 & 2.05 & 1.33 & 1.61 & 0.39 & 24 \\
\hline PCB 106 & 0.0200 & 0.104 & 0.0151 & 0.0367 & 0.0176 & 0.0387 & 0.037 & 97 \\
\hline PCB 107 & 0.256 & 0.337 & 0.212 & 0.379 & 0.331 & 0.303 & 0.067 & 22 \\
\hline PCB 110 & $<\mathrm{LOD}$ & $<\mathrm{LOD}$ & $<\mathrm{LOD}$ & $<\mathrm{LOD}$ & $<\mathrm{LOD}$ & $<$ LOD & & \\
\hline PCB 112 & $<\mathrm{LOQ}$ & 0.0161 & 0.0178 & 0.0258 & 0.0101 & 0.0175 & 0.0065 & 37 \\
\hline PCB 114 & 0.148 & 0.235 & 0.142 & 0.244 & 0.134 & 0.181 & 0.054 & 30 \\
\hline PCB 118 & 4.02 & 7.29 & 4.40 & 5.83 & 4.50 & 5.21 & 1.3 & 26 \\
\hline PCB 119 & 0.0283 & 0.151 & 0.0926 & 0.135 & 0.0797 & 0.0974 & 0.049 & 50 \\
\hline PCB 127 & $<$ LOQ & $<$ LOQ & $<\mathrm{LOQ}$ & $<\mathrm{LOQ}$ & $<\mathrm{LOQ}$ & $<\mathbf{L O Q}$ & & \\
\hline PCB 128 & 0.278 & 0.856 & 0.512 & 0.807 & 0.524 & 0.595 & 0.24 & 40 \\
\hline PCB 130 & 0.127 & 0.329 & 0.233 & 0.367 & 0.210 & 0.253 & 0.096 & 38 \\
\hline PCB 137 & 0.0592 & 0.257 & 0.169 & 0.187 & 0.158 & 0.166 & 0.071 & 43 \\
\hline PCB 138 & 2.18 & 6.54 & 4.05 & 4.41 & 4.22 & 4.28 & 1.5 & 36 \\
\hline PCB 146 & 1.64 & 3.14 & 1.91 & 2.29 & 1.83 & 2.16 & 0.60 & 28 \\
\hline PCB 149 & 0.224 & 0.366 & 0.307 & 0.354 & 0.273 & 0.305 & 0.058 & 19 \\
\hline
\end{tabular}


Appendix 31 (Continued).

\begin{tabular}{|c|c|c|c|c|c|c|c|c|}
\hline Compound & 1454 & 1455 & 1457 & 1458 & 1460 & Mean & SD & RSD \\
\hline PCB 151 & $<\mathrm{LOQ}$ & $<\mathrm{LOQ}$ & $<\mathrm{LOQ}$ & $<$ LOQ & $<$ LOQ & $<\mathbf{L O Q}$ & & \\
\hline PCB $153+132$ & 6.12 & 16.2 & 9.57 & 11.4 & 9.48 & 10.6 & 3.7 & 35 \\
\hline PCB 154 & $<\mathrm{LOQ}$ & 0.0924 & 0.0883 & 0.0912 & 0.0717 & 0.0859 & 0.0096 & 11 \\
\hline PCB 156 & 0.375 & 0.461 & 0.339 & 0.520 & 0.342 & 0.407 & 0.080 & 20 \\
\hline PCB 157 & 0.0934 & 0.139 & 0.0972 & 0.142 & 0.0962 & 0.113 & 0.024 & 22 \\
\hline PCB 158 & 0.178 & 0.434 & 0.209 & 0.292 & 0.249 & 0.272 & 0.10 & 37 \\
\hline РCB 159 & $<\mathrm{LOQ}$ & $<\mathrm{LOQ}$ & $<\mathrm{LOQ}$ & $<$ LOQ & $<\mathrm{LOQ}$ & $<\mathbf{L O Q}$ & & \\
\hline PCB 163 & 1.29 & 2.54 & 1.56 & 2.39 & 1.62 & 1.88 & 0.55 & 29 \\
\hline PCB 165 & $<\mathrm{LOQ}$ & 0.0366 & 0.0340 & 0.0363 & 0.0339 & 0.0352 & 0.0015 & 4.1 \\
\hline PCB 166 & 0.0342 & 0.0459 & 0.0342 & 0.0316 & 0.0370 & 0.0366 & 0.0055 & 15 \\
\hline PCB 167 & 0.248 & 0.395 & 0.264 & 0.314 & 0.243 & 0.293 & 0.064 & 22 \\
\hline PCB 170 & 0.689 & 1.20 & 0.782 & 1.03 & 0.686 & 0.877 & 0.23 & 26 \\
\hline PCB 172 & 0.269 & 0.380 & 0.269 & 0.336 & 0.203 & 0.291 & 0.068 & 23 \\
\hline PCB 174 & $<\mathrm{LOQ}$ & 0.0689 & $<\mathrm{LOQ}$ & 0.0652 & $<$ LOQ & 0.0670 & 0.0026 & 3.8 \\
\hline PCB 175 & 0.0614 & 0.117 & 0.0790 & 0.0994 & 0.0527 & 0.0818 & 0.026 & 32 \\
\hline PCB 176 & 0.0302 & 0.0314 & 0.0312 & 0.0391 & 0.0301 & 0.0324 & 0.0038 & 12 \\
\hline PCB 177 & 0.119 & 0.332 & 0.268 & 0.317 & 0.240 & 0.255 & 0.085 & 33 \\
\hline PCB 178 & 0.372 & 0.530 & 0.394 & 0.509 & 0.304 & 0.422 & 0.096 & 23 \\
\hline PCB $180+193$ & 1.09 & 2.79 & 1.82 & 2.02 & 1.57 & 1.86 & 0.62 & 34 \\
\hline РCB 183 & 0.595 & 0.893 & 0.616 & 0.782 & 0.503 & 0.678 & 0.16 & 23 \\
\hline PCB 185 & $<\mathrm{LOQ}$ & 0.0220 & $<\mathrm{LOQ}$ & 0.0138 & $<\mathrm{LOQ}$ & 0.0179 & 0.0058 & 33 \\
\hline PCB 187 & 1.60 & 4.35 & 2.55 & 3.59 & 2.34 & 2.88 & 1.1 & 38 \\
\hline PCB 188 & 0.0321 & 0.0442 & 0.0425 & 0.0440 & 0.0301 & 0.0386 & 0.0069 & 18 \\
\hline PCB 189 & 0.0397 & 0.0516 & 0.0203 & 0.0151 & 0.0358 & 0.0325 & 0.015 & 46 \\
\hline PCB 191 & $<\mathrm{LOQ}$ & $<\mathrm{LOQ}$ & $<\mathrm{LOQ}$ & $<$ LOQ & $<$ LOQ & $<\mathrm{LOQ}$ & & \\
\hline PCB 194 & 0.271 & 0.396 & 0.321 & 0.307 & 0.182 & 0.296 & 0.078 & 26 \\
\hline PCB 195 & 0.101 & 0.136 & 0.103 & 0.126 & 0.0700 & 0.107 & 0.025 & 24 \\
\hline PCB 196 & 0.452 & 0.735 & 0.515 & 0.577 & 0.435 & 0.543 & 0.12 & 22 \\
\hline PCB 197 & 0.0337 & 0.0556 & 0.0459 & 0.0841 & 0.0346 & 0.0508 & 0.021 & 41 \\
\hline PCB 199 & 1.91 & 3.14 & 2.18 & 2.35 & 1.45 & 2.21 & 0.63 & 28 \\
\hline PCB 200 & $<\mathrm{LOQ}$ & $<\mathrm{LOQ}$ & $<$ LOQ & $<$ LOQ & $<\mathrm{LOQ}$ & $<\mathbf{L O Q}$ & & \\
\hline PCB 201 & 0.582 & 1.24 & 0.802 & 0.928 & 0.530 & 0.816 & 0.29 & 35 \\
\hline PCB 202 & $<\mathrm{LOQ}$ & $<\mathrm{LOQ}$ & $<\mathrm{LOQ}$ & $<\mathrm{LOQ}$ & $<\mathrm{LOQ}$ & $<\mathbf{L O Q}$ & & \\
\hline PCB 205 & 0.0350 & 0.0364 & 0.0415 & 0.0516 & 0.0278 & 0.0385 & 0.0088 & 23 \\
\hline PCB 206 & $<\mathrm{LOQ}$ & 0.254 & 0.233 & $<\mathrm{LOQ}$ & $<\mathrm{LOQ}$ & 0.244 & 0.015 & 6.0 \\
\hline PCB 207 & 0.0492 & 0.0975 & 0.0577 & 0.0660 & 0.0531 & 0.0647 & 0.019 & 30 \\
\hline РCB 208 & 0.106 & 0.146 & 0.129 & 0.111 & 0.0870 & 0.116 & 0.023 & 19 \\
\hline PCB 209 & $<\mathrm{LOQ}$ & 0.139 & 0.0764 & 0.0731 & 0.0566 & 0.0864 & 0.036 & 42 \\
\hline
\end{tabular}


Appendix 32. Brominated diphenyl ether (BDE) and polychlorinated biphenyl (PCB) mass fractions (ng g ${ }^{-1}$ wet mass) in thick-billed murre eggs collected at Little Diomede Island, Alaska in 2008 (compounds shown in red and blue were above and below reference value ranges, respectively).

\begin{tabular}{|c|c|c|c|c|c|c|c|c|}
\hline Compound & 1250 & 1256 & 1257 & 1260 & 1261 & Mean & SD & RSD \\
\hline BDE47 & 0.597 & 0.589 & 0.408 & 0.520 & 0.536 & 0.530 & 0.076 & 14 \\
\hline BDE99 & $<\mathrm{LOQ}$ & $<\mathrm{LOQ}$ & $<\mathrm{LOQ}$ & $<\mathrm{LOQ}$ & 0.870 & $<$ LOQ & & \\
\hline BDE100 & 0.565 & 0.564 & 0.610 & 0.532 & 0.604 & 0.575 & 0.032 & 5.6 \\
\hline PCB 8 & $<\mathrm{LOD}$ & $<\mathrm{LOD}$ & $<\mathrm{LOD}$ & $<\mathrm{LOD}$ & $<\mathrm{LOD}$ & $<$ LOD & & \\
\hline PCB 18 & $<\mathrm{LOD}$ & $<\mathrm{LOD}$ & $<\mathrm{LOD}$ & $<\mathrm{LOD}$ & $<\mathrm{LOD}$ & $<$ LOD & & \\
\hline PCB $28+31$ & 4.25 & 5.12 & 4.02 & 5.09 & 3.28 & 4.35 & 0.77 & 18 \\
\hline PCB 29 & $<\mathrm{LOQ}$ & $<\mathrm{LOQ}$ & $<\mathrm{LOQ}$ & $<$ LOQ & $<\mathrm{LOQ}$ & $<\mathrm{LOQ}$ & & \\
\hline PCB 44 & 0.0826 & 0.0577 & 0.0569 & 0.0806 & 0.0689 & 0.0693 & 0.012 & 18 \\
\hline PCB 45 & $<\mathrm{LOQ}$ & $<\mathrm{LOQ}$ & $<\mathrm{LOQ}$ & $<\mathrm{LOQ}$ & $<\mathrm{LOQ}$ & $<$ LOQ & & \\
\hline PCB 49 & 0.0981 & 0.127 & 0.0779 & 0.0778 & 0.125 & 0.101 & 0.024 & 24 \\
\hline PCB 52 & 0.244 & 0.252 & 0.118 & 0.131 & 0.219 & 0.193 & 0.064 & 33 \\
\hline PCB 56 & $<\mathrm{LOQ}$ & $<$ LOQ & $<\mathrm{LOQ}$ & $<\mathrm{LOQ}$ & $<\mathrm{LOQ}$ & $<$ LOQ & & \\
\hline PCB 63 & 0.250 & 0.241 & 0.238 & 0.257 & 0.194 & 0.236 & 0.025 & 10 \\
\hline PCB 66 & 2.91 & 3.37 & 2.83 & 3.31 & 2.36 & 2.96 & 0.41 & 14 \\
\hline РCB 70 & 0.101 & 0.103 & 0.0394 & 0.0498 & 0.111 & 0.0807 & 0.033 & 41 \\
\hline РCB 74 & 2.42 & 2.73 & 2.23 & 2.60 & 2.00 & 2.40 & 0.29 & 12 \\
\hline РCB 79 & $<\mathrm{LOQ}$ & $<$ LOQ & $<$ LOQ & $<\mathrm{LOQ}$ & $<\mathrm{LOQ}$ & $<$ LOQ & & \\
\hline PCB 82 & 0.00533 & $<\mathrm{LOD}$ & $<\mathrm{LOD}$ & $<\mathrm{LOD}$ & 0.0167 & 0.0110 & 0.0081 & 73 \\
\hline PCB 87 & 0.151 & 0.175 & 0.0790 & 0.126 & 0.149 & 0.136 & 0.036 & 27 \\
\hline РCB 92 & 0.0783 & 0.113 & 0.0579 & 0.0650 & 0.0847 & 0.0798 & 0.021 & 27 \\
\hline PCB 95+121 & $<\mathrm{LOD}$ & $<\mathrm{LOD}$ & $<\mathrm{LOD}$ & $<\mathrm{LOD}$ & $<\mathrm{LOD}$ & $<$ LOD & & \\
\hline PCB 99 & 7.28 & 8.14 & 6.19 & 7.29 & 6.17 & 7.01 & 0.83 & 12 \\
\hline PCB 101 & 0.129 & 0.220 & $<\mathrm{LOD}$ & 0.0500 & 0.196 & 0.149 & 0.076 & 51 \\
\hline PCB 105 & 2.00 & 2.55 & 1.97 & 2.46 & 1.73 & 2.14 & 0.35 & 16 \\
\hline PCB 106 & 0.0168 & $<$ LOQ & $<$ LOQ & $<$ LOQ & $<$ LOQ & $<$ LOQ & & \\
\hline PCB 107 & 0.468 & 0.524 & 0.489 & 0.520 & 0.399 & 0.480 & 0.051 & 11 \\
\hline PCB 110 & $<\mathrm{LOD}$ & $<\mathrm{LOD}$ & $<\mathrm{LOD}$ & $<\mathrm{LOD}$ & $<\mathrm{LOD}$ & $<$ LOD & & \\
\hline PCB 112 & $<\mathrm{LOD}$ & $<\mathrm{LOD}$ & $<\mathrm{LOD}$ & $<\mathrm{LOD}$ & $<\mathrm{LOD}$ & $<$ LOD & & \\
\hline PCB 114 & 0.224 & 0.292 & 0.243 & 0.272 & 0.224 & 0.251 & 0.030 & 12 \\
\hline PCB 118 & 7.76 & 9.23 & 7.19 & 8.25 & 7.00 & 7.89 & 0.90 & 11 \\
\hline PCB 119 & 0.171 & 0.191 & 0.146 & 0.167 & 0.148 & 0.165 & 0.018 & 11 \\
\hline PCB 127 & $<\mathrm{LOD}$ & $<\mathrm{LOD}$ & $<\mathrm{LOD}$ & $<\mathrm{LOD}$ & $<\mathrm{LOD}$ & $<$ LOD & & \\
\hline PCB 128 & 1.13 & 1.14 & 0.766 & 0.945 & 0.804 & 0.957 & 0.18 & 18 \\
\hline PCB 130 & 0.353 & 0.433 & 0.272 & 0.330 & 0.315 & 0.340 & 0.059 & 17 \\
\hline PCB 137 & 0.365 & 0.372 & 0.261 & 0.296 & 0.309 & 0.321 & 0.047 & 15 \\
\hline PCB 138 & 7.45 & 7.79 & 5.56 & 6.59 & 6.18 & 6.71 & 0.91 & 14 \\
\hline PCB 146 & 3.23 & 3.71 & 3.03 & 3.34 & 3.03 & 3.27 & 0.28 & 8.7 \\
\hline PCB 149 & 0.483 & 0.524 & 0.400 & 0.373 & 0.479 & 0.452 & 0.063 & 14 \\
\hline
\end{tabular}


Appendix 32 (Continued).

\begin{tabular}{|c|c|c|c|c|c|c|c|c|}
\hline Compound & 1250 & 1256 & 1257 & 1260 & 1261 & Mean & SD & RSD \\
\hline PCB 151 & 0.0861 & 0.0834 & $<$ LOQ & $<$ LOQ & $<\mathrm{LOQ}$ & 0.0847 & 0.0019 & 2.2 \\
\hline РCB $153+132$ & 17.0 & 18.7 & 13.7 & 15.2 & 15.4 & 16.0 & 1.9 & 12 \\
\hline РCB 154 & 0.127 & 0.126 & 0.0871 & 0.0962 & 0.122 & 0.112 & 0.019 & 17 \\
\hline PCB 156 & 0.575 & 0.749 & 0.599 & 0.619 & 0.536 & 0.615 & 0.081 & 13 \\
\hline PCB 157 & 0.196 & 0.241 & 0.187 & 0.182 & 0.151 & 0.191 & 0.033 & 17 \\
\hline PCB 158 & 0.379 & 0.371 & 0.200 & 0.218 & 0.302 & 0.294 & 0.083 & 28 \\
\hline PCB 159 & $<\mathrm{LOQ}$ & $<$ LOQ & $<\mathrm{LOQ}$ & $<\mathrm{LOQ}$ & $<\mathrm{LOQ}$ & $<$ LOQ & & \\
\hline PCB 163 & 2.83 & 3.04 & 2.54 & 2.77 & 2.64 & 2.76 & 0.19 & 7.0 \\
\hline PCB 165 & 0.0297 & 0.0248 & 0.0287 & 0.0319 & 0.0148 & 0.0260 & 0.0068 & 26 \\
\hline PCB 166 & 0.0591 & 0.0574 & 0.0599 & 0.0543 & 0.0485 & 0.0558 & 0.0047 & 8.3 \\
\hline PCB 167 & 0.365 & 0.418 & 0.304 & 0.346 & 0.311 & 0.349 & 0.046 & 13 \\
\hline PCB 170 & 1.12 & 1.35 & 1.11 & 1.18 & 1.11 & 1.18 & 0.10 & 8.8 \\
\hline PCB 172 & 0.384 & 0.439 & 0.380 & 0.402 & 0.345 & 0.390 & 0.034 & 8.8 \\
\hline PCB 174 & 0.0367 & 0.0665 & 0.0340 & 0.0595 & 0.0500 & 0.0493 & 0.014 & 29 \\
\hline PCB 175 & 0.0930 & 0.100 & 0.0613 & 0.0795 & 0.0768 & 0.0821 & 0.015 & 18 \\
\hline PCB 176 & 0.00649 & $<\mathrm{LOQ}$ & 0.00896 & 0.00890 & 0.00802 & 0.00809 & 0.0012 & 14 \\
\hline PCB 177 & 0.278 & 0.288 & 0.171 & 0.207 & 0.261 & 0.241 & 0.050 & 21 \\
\hline PCB 178 & 0.530 & 0.430 & 0.194 & 0.384 & 0.267 & 0.361 & 0.13 & 37 \\
\hline РCB $180+193$ & 2.87 & 3.17 & 2.35 & 2.61 & 2.81 & 2.76 & 0.31 & 11 \\
\hline РCB 183 & 0.793 & 0.918 & 0.754 & 0.834 & 0.763 & 0.812 & 0.067 & 8.2 \\
\hline PCB 185 & 0.0377 & 0.0419 & 0.0268 & 0.0423 & 0.0367 & 0.0371 & 0.0062 & 17 \\
\hline PCB 187 & 3.53 & 3.80 & 2.77 & 3.14 & 3.21 & 3.29 & 0.39 & 12 \\
\hline PCB 188 & 0.0259 & 0.0263 & 0.0194 & 0.0240 & 0.0191 & 0.0229 & 0.0035 & 15 \\
\hline PCB 189 & 0.0500 & 0.0266 & $<\mathrm{LOQ}$ & $<\mathrm{LOQ}$ & $<\mathrm{LOQ}$ & 0.0383 & 0.017 & 43 \\
\hline PCB 191 & 0.0280 & 0.0223 & 0.0381 & 0.0369 & 0.0288 & 0.0308 & 0.0066 & 21 \\
\hline PCB 194 & 0.336 & 0.409 & 0.340 & 0.380 & 0.296 & 0.352 & 0.044 & 12 \\
\hline PCB 195 & 0.175 & 0.186 & 0.144 & 0.166 & 0.160 & 0.166 & 0.016 & 9.6 \\
\hline РCB 196 & 0.898 & 0.859 & 0.773 & 0.862 & 0.811 & 0.841 & 0.049 & 5.8 \\
\hline PCB 197 & 0.0652 & 0.0688 & 0.0503 & 0.0513 & 0.0440 & 0.0560 & 0.011 & 19 \\
\hline PCB 199 & 3.34 & 3.47 & 3.17 & 3.55 & 3.08 & 3.32 & 0.20 & 5.9 \\
\hline PCB 200 & $<\mathrm{LOD}$ & $<\mathrm{LOD}$ & $<\mathrm{LOD}$ & $<\mathrm{LOD}$ & $<\mathrm{LOD}$ & $<$ LOD & & \\
\hline PCB 201 & 1.34 & 1.08 & 0.922 & 1.23 & 0.932 & 1.10 & 0.18 & 17 \\
\hline PCB 202 & 0.0663 & 0.0705 & 0.0639 & 0.0488 & 0.0533 & 0.0606 & 0.0091 & 15 \\
\hline PCB 205 & 0.0215 & 0.0336 & 0.0259 & 0.0296 & 0.0290 & 0.0279 & 0.0045 & 16 \\
\hline PCB 206 & 0.266 & 0.210 & 0.242 & 0.325 & 0.221 & 0.253 & 0.046 & 18 \\
\hline PCB 207 & 0.0755 & 0.0857 & 0.0546 & 0.0680 & 0.0632 & 0.0694 & 0.012 & 17 \\
\hline PCB 208 & 0.121 & 0.0865 & 0.0896 & 0.154 & 0.148 & 0.120 & 0.031 & 26 \\
\hline PCB 209 & 0.134 & 0.115 & 0.125 & 0.185 & 0.140 & 0.140 & 0.027 & 19 \\
\hline
\end{tabular}


Appendix 33. Brominated diphenyl ether (BDE) and polychlorinated biphenyl (PCB) mass fractions (ng g ${ }^{-1}$ wet mass) in common murre eggs collected at St. Lawrence Island, Alaska in 2008 (compounds shown in red and blue were above and below reference value ranges, respectively).

\begin{tabular}{|c|c|c|c|c|c|c|c|c|}
\hline Compound & 1265 & 1266 & 1267 & 1268 & 1275 & Mean & SD & RSD \\
\hline BDE47 & 0.326 & 0.297 & 0.278 & 0.223 & 0.348 & 0.294 & 0.048 & 16 \\
\hline BDE99 & $<\mathrm{LOQ}$ & $<\mathrm{LOQ}$ & $<\mathrm{LOQ}$ & $<\mathrm{LOQ}$ & $<\mathrm{LOQ}$ & $<\mathrm{LOQ}$ & & \\
\hline BDE100 & 0.579 & 0.495 & 0.538 & 0.542 & 0.585 & 0.548 & 0.037 & 6.7 \\
\hline PCB 8 & 0.154 & $<$ LOD & 0.0908 & 0.0182 & 0.116 & 0.0948 & 0.057 & 60 \\
\hline PCB 18 & $<\mathrm{LOD}$ & $<$ LOD & $<\mathrm{LOD}$ & $<\mathrm{LOD}$ & $<\mathrm{LOD}$ & $<$ LOD & & \\
\hline PCB $28+31$ & 1.77 & 2.51 & 3.63 & 2.57 & 3.23 & 2.74 & 0.72 & 26 \\
\hline PCB 29 & $<\mathrm{LOQ}$ & $<\mathrm{LOQ}$ & $<\mathrm{LOQ}$ & $<\mathrm{LOQ}$ & $<\mathrm{LOQ}$ & $<\mathrm{LOQ}$ & & \\
\hline PCB 44 & 0.0613 & 0.0727 & 0.0853 & 0.0604 & 0.0724 & 0.0704 & 0.010 & 14 \\
\hline РCB 45 & 0.519 & $<\mathrm{LOQ}$ & $<\mathrm{LOQ}$ & $<\mathrm{LOQ}$ & $<\mathrm{LOQ}$ & $<\mathrm{LOQ}$ & & \\
\hline РCB 49 & 0.0792 & 0.0723 & 0.0636 & 0.0903 & 0.0899 & 0.0791 & 0.011 & 15 \\
\hline РCB 52 & 0.130 & 0.148 & 0.0801 & 0.130 & 0.135 & 0.125 & 0.026 & 21 \\
\hline РCB 56 & $<$ LOQ & $<\mathrm{LOQ}$ & $<\mathrm{LOQ}$ & $<\mathrm{LOQ}$ & $<\mathrm{LOQ}$ & $<\mathbf{L O Q}$ & & \\
\hline PCB 63 & $<\mathrm{LOQ}$ & $<$ LOQ & $<\mathrm{LOQ}$ & $<$ LOQ & $<\mathrm{LOQ}$ & $<\mathrm{LOQ}$ & & \\
\hline РCB 66 & 2.27 & 2.77 & 2.47 & 2.16 & 2.29 & 2.39 & 0.24 & 10 \\
\hline РCB 70 & 0.0543 & 0.0662 & 0.0292 & 0.0664 & 0.0560 & 0.0544 & 0.015 & 28 \\
\hline РCB 74 & 1.87 & 2.25 & 2.01 & 1.82 & 1.85 & 1.96 & 0.18 & 9.0 \\
\hline РCB 79 & $<\mathrm{LOQ}$ & $<\mathrm{LOQ}$ & $<\mathrm{LOQ}$ & $<\mathrm{LOQ}$ & $<\mathrm{LOQ}$ & $<\mathrm{LOQ}$ & & \\
\hline РCB 82 & $<\mathrm{LOD}$ & $<\mathrm{LOD}$ & $<\mathrm{LOD}$ & $<\mathrm{LOD}$ & $<\mathrm{LOD}$ & $<$ LOD & & \\
\hline РCB 87 & 0.0454 & 0.108 & 0.0766 & 0.0665 & 0.0526 & 0.0698 & 0.024 & 35 \\
\hline РCB 92 & 0.0485 & 0.0642 & 0.0375 & 0.0435 & 0.0589 & 0.0505 & 0.011 & 22 \\
\hline PCB 95+121 & $<\mathrm{LOD}$ & $<\mathrm{LOD}$ & $<\mathrm{LOD}$ & $<\mathrm{LOD}$ & $<\mathrm{LOD}$ & $<$ LOD & & \\
\hline PCB 99 & 4.59 & 5.79 & 5.00 & 4.49 & 4.18 & 4.81 & 0.62 & 13 \\
\hline PCB 101 & $<\mathrm{LOD}$ & 0.0397 & $<\mathrm{LOD}$ & $<\mathrm{LOD}$ & $<\mathrm{LOD}$ & $<$ LOD & & \\
\hline PCB 105 & 1.63 & 2.34 & 1.59 & 1.34 & 1.44 & 1.67 & 0.39 & 24 \\
\hline PCB 106 & 0.0124 & $<$ LOQ & $<$ LOQ & 0.0128 & 0.0125 & 0.0126 & 0.00021 & 1.7 \\
\hline PCB 107 & 0.219 & 0.371 & 0.341 & 0.232 & 0.296 & 0.292 & 0.066 & 23 \\
\hline PCB 110 & $<\mathrm{LOD}$ & $<\mathrm{LOD}$ & $<\mathrm{LOD}$ & $<\mathrm{LOD}$ & $<\mathrm{LOD}$ & $<$ LOD & & \\
\hline PCB 112 & $<\mathrm{LOD}$ & $<$ LOD & $<\mathrm{LOD}$ & $<\mathrm{LOD}$ & $<\mathrm{LOD}$ & $<$ LOD & & \\
\hline PCB 114 & 0.181 & 0.260 & 0.175 & 0.181 & 0.174 & 0.194 & 0.037 & 19 \\
\hline PCB 118 & 6.36 & 8.44 & 5.71 & 5.61 & 5.23 & 6.27 & 1.3 & 20 \\
\hline PCB 119 & 0.109 & 0.140 & 0.108 & 0.108 & 0.0925 & 0.111 & 0.017 & 15 \\
\hline PCB 127 & $<\mathrm{LOD}$ & $<\mathrm{LOD}$ & $<\mathrm{LOD}$ & $<\mathrm{LOD}$ & $<\mathrm{LOD}$ & $<$ LOD & & \\
\hline PCB 128 & 0.679 & 0.795 & 0.645 & 0.611 & 0.551 & 0.656 & 0.091 & 14 \\
\hline PCB 130 & 0.328 & 0.324 & 0.231 & 0.363 & 0.188 & 0.287 & 0.074 & 26 \\
\hline PCB 137 & 0.248 & 0.343 & 0.207 & 0.253 & 0.189 & 0.248 & 0.060 & 24 \\
\hline PCB 138 & 4.62 & 6.27 & 4.15 & 4.15 & 3.80 & 4.60 & 0.98 & 21 \\
\hline PCB 146 & 2.06 & 2.85 & 2.33 & 2.18 & 2.18 & 2.32 & 0.31 & 13 \\
\hline PCB 149 & 0.326 & 0.373 & 0.325 & 0.314 & 0.351 & 0.338 & 0.024 & 7.1 \\
\hline
\end{tabular}


Appendix 33 (Continued).

\begin{tabular}{|c|c|c|c|c|c|c|c|c|}
\hline Compound & 1265 & 1266 & 1267 & 1268 & 1275 & Mean & SD & RSD \\
\hline PCB 151 & 0.0784 & $<\mathrm{LOQ}$ & $<$ LOQ & $<$ LOQ & $<$ LOQ & $<$ LOQ & & \\
\hline PCB $153+132$ & 10.2 & 13.9 & 9.99 & 10.6 & 9.30 & 10.8 & 1.8 & 17 \\
\hline PCB 154 & 0.100 & 0.0918 & 0.0714 & 0.0927 & 0.0847 & 0.0882 & 0.011 & 12 \\
\hline PCB 156 & 0.508 & 0.664 & 0.472 & 0.430 & 0.446 & 0.504 & 0.094 & 19 \\
\hline PCB 157 & 0.158 & 0.182 & 0.141 & 0.123 & 0.124 & 0.146 & 0.025 & 17 \\
\hline PCB 158 & 0.176 & 0.360 & 0.271 & 0.229 & 0.188 & 0.245 & 0.074 & 30 \\
\hline PCB 159 & $<\mathrm{LOQ}$ & $<\mathrm{LOQ}$ & $<\mathrm{LOQ}$ & $<\mathrm{LOQ}$ & $<\mathrm{LOQ}$ & $<$ LOQ & & \\
\hline PCB 163 & 1.84 & 2.33 & 1.75 & 1.81 & 1.68 & 1.88 & 0.26 & 14 \\
\hline PCB 165 & 0.0259 & 0.0359 & 0.0228 & 0.0268 & 0.0174 & 0.0258 & 0.0068 & 26 \\
\hline PCB 166 & 0.0374 & 0.0471 & 0.0410 & 0.0358 & 0.0511 & 0.0425 & 0.0065 & 15 \\
\hline PCB 167 & 0.241 & 0.401 & 0.222 & 0.220 & 0.212 & 0.259 & 0.080 & 31 \\
\hline PCB 170 & 0.787 & 1.09 & 0.739 & 0.789 & 0.782 & $\mathbf{0 . 8 3 7}$ & 0.14 & 17 \\
\hline PCB 172 & 0.279 & 0.383 & 0.282 & 0.281 & 0.324 & 0.310 & 0.045 & 14 \\
\hline PCB 174 & 0.0399 & 0.0410 & 0.0477 & 0.0376 & 0.0344 & 0.0401 & 0.0049 & 12 \\
\hline PCB 175 & 0.0358 & 0.0844 & 0.0519 & 0.0526 & 0.0566 & 0.0563 & 0.018 & 31 \\
\hline PCB 176 & $<\mathrm{LOQ}$ & $<\mathrm{LOQ}$ & 0.00496 & 0.0106 & $<\mathrm{LOQ}$ & 0.00777 & 0.0040 & 51 \\
\hline PCB 177 & 0.157 & 0.203 & 0.137 & 0.162 & 0.125 & 0.157 & 0.030 & 19 \\
\hline РCB 178 & 0.145 & 0.279 & 0.183 & 0.159 & 0.119 & 0.177 & 0.062 & 35 \\
\hline PCB $180+193$ & 1.87 & 2.58 & 1.68 & 1.95 & 1.77 & 1.97 & 0.35 & 18 \\
\hline PCB 183 & 0.394 & 0.617 & 0.517 & 0.393 & 0.500 & 0.484 & 0.094 & 19 \\
\hline PCB 185 & 0.0180 & 0.0128 & 0.0176 & 0.0179 & 0.0169 & 0.0166 & 0.0022 & 13 \\
\hline PCB 187 & 1.41 & 2.74 & 1.69 & 1.74 & 1.69 & 1.85 & 0.51 & 28 \\
\hline PCB 188 & 0.00784 & 0.0314 & 0.0197 & 0.0151 & 0.0200 & 0.0188 & 0.0086 & 46 \\
\hline PCB 189 & $<\mathrm{LOQ}$ & 0.0211 & 0.0548 & 0.0627 & 0.0574 & 0.0490 & 0.019 & 39 \\
\hline PCB 191 & 0.0258 & 0.0195 & 0.0177 & 0.0229 & 0.0255 & 0.0223 & 0.0036 & 16 \\
\hline PCB 194 & 0.133 & 0.220 & 0.218 & 0.143 & 0.251 & 0.193 & 0.052 & 27 \\
\hline PCB 195 & 0.108 & 0.119 & 0.140 & 0.121 & 0.134 & 0.124 & 0.013 & 10 \\
\hline PCB 196 & 0.612 & 0.699 & 0.683 & 0.652 & 0.751 & 0.679 & 0.052 & 7.6 \\
\hline PCB 197 & 0.0483 & 0.0408 & 0.0547 & 0.0469 & 0.0557 & 0.0493 & 0.0061 & 12 \\
\hline PCB 199 & 1.91 & 2.68 & 2.71 & 2.49 & 2.83 & 2.52 & 0.37 & 15 \\
\hline PCB 200 & $<\mathrm{LOD}$ & $<$ LOD & $<\mathrm{LOD}$ & $<\mathrm{LOD}$ & $<\mathrm{LOD}$ & $<$ LOD & & \\
\hline PCB 201 & 0.491 & 0.614 & 0.835 & 0.847 & 0.806 & 0.719 & 0.16 & 22 \\
\hline PCB 202 & 0.0388 & 0.0620 & $<\mathrm{LOQ}$ & 0.0548 & 0.0405 & 0.0490 & 0.011 & 23 \\
\hline PCB 205 & 0.0216 & 0.0185 & 0.0258 & 0.0307 & 0.0316 & 0.0256 & 0.0057 & 22 \\
\hline PCB 206 & 0.170 & 0.364 & 0.199 & 0.321 & 0.216 & 0.254 & 0.084 & 33 \\
\hline PCB 207 & 0.0508 & 0.0611 & 0.0631 & 0.0898 & 0.0718 & 0.0673 & 0.015 & 22 \\
\hline РCB 208 & 0.111 & 0.203 & 0.164 & 0.208 & 0.130 & 0.163 & 0.043 & 26 \\
\hline PCB 209 & 0.106 & 0.151 & 0.138 & 0.182 & 0.183 & 0.152 & 0.032 & 21 \\
\hline
\end{tabular}


Appendix 34. Brominated diphenyl ether (BDE) and polychlorinated biphenyl (PCB) mass fractions (ng g ${ }^{-1}$ wet mass) in thick-billed murre eggs collected at St. Lawrence Island, Alaska in 2008 (compounds shown in red and blue were above and below reference value ranges, respectively).

\begin{tabular}{|c|c|c|c|c|c|c|c|c|}
\hline Compound & 1278 & 1279 & 1281 & 1284 & 1287 & Mean & SD & RSD \\
\hline BDE47 & 0.501 & 0.174 & 0.282 & 0.187 & 0.549 & 0.339 & 0.18 & 52 \\
\hline BDE99 & 0.875 & $<\mathrm{LOQ}$ & $<\mathrm{LOQ}$ & $<\mathrm{LOQ}$ & 0.929 & 0.902 & 0.038 & 4.2 \\
\hline BDE100 & 0.513 & 0.511 & 0.460 & 0.585 & 0.746 & 0.563 & 0.11 & 20 \\
\hline PCB 8 & 0.0344 & $<\mathrm{LOD}$ & 0.0400 & $<\mathrm{LOD}$ & $<\mathrm{LOD}$ & 0.0372 & 0.0039 & 11 \\
\hline PCB 18 & $<\mathrm{LOD}$ & $<\mathrm{LOD}$ & $<\mathrm{LOD}$ & $<\mathrm{LOD}$ & $<\mathrm{LOD}$ & $<$ LOD & & \\
\hline PCB $28+31$ & 3.73 & 3.15 & 2.65 & 3.33 & 3.34 & 3.24 & 0.39 & 12 \\
\hline PCB 29 & $<\mathrm{LOQ}$ & $<\mathrm{LOQ}$ & $<\mathrm{LOQ}$ & $<\mathrm{LOQ}$ & $<\mathrm{LOQ}$ & $<$ LOQ & & \\
\hline PCB 44 & 0.0548 & 0.0489 & 0.0541 & 0.0549 & 0.0592 & 0.0544 & 0.0037 & 6.7 \\
\hline PCB 45 & $<\mathrm{LOQ}$ & $<\mathrm{LOQ}$ & $<\mathrm{LOQ}$ & $<\mathrm{LOQ}$ & $<\mathrm{LOQ}$ & $<$ LOQ & & \\
\hline PCB 49 & 0.0617 & 0.0586 & 0.0538 & 0.0734 & 0.0827 & 0.0661 & 0.012 & 18 \\
\hline PCB 52 & 0.0909 & 0.0821 & 0.0668 & 0.0876 & 0.118 & 0.0891 & 0.019 & 21 \\
\hline PCB 56 & $<$ LOQ & $<\mathrm{LOQ}$ & $<\mathrm{LOQ}$ & $<\mathrm{LOQ}$ & $<$ LOQ & $<$ LOQ & & \\
\hline PCB 63 & 0.213 & $<\mathrm{LOQ}$ & $<$ LOQ & 0.191 & $<\mathrm{LOQ}$ & 0.202 & 0.016 & 7.7 \\
\hline PCB 66 & 2.63 & 2.29 & 1.87 & 2.60 & 2.56 & 2.39 & 0.32 & 13 \\
\hline PCB 70 & 0.0298 & 0.0335 & 0.0161 & 0.0271 & 0.0511 & 0.0315 & 0.013 & 40 \\
\hline PCB 74 & 2.24 & 1.90 & 1.50 & 2.14 & 2.20 & 2.00 & 0.31 & 15 \\
\hline PCB 79 & $<\mathrm{LOQ}$ & $<\mathrm{LOQ}$ & $<\mathrm{LOQ}$ & $<\mathrm{LOQ}$ & $<$ LOQ & $<$ LOQ & & \\
\hline PCB 82 & $<\mathrm{LOD}$ & $<\mathrm{LOD}$ & $<\mathrm{LOD}$ & $<\mathrm{LOD}$ & $<\mathrm{LOD}$ & $<$ LOD & & \\
\hline PCB 87 & 0.0935 & 0.0408 & 0.0296 & 0.0767 & 0.0797 & 0.0641 & 0.027 & 43 \\
\hline PCB 92 & 0.0371 & 0.0333 & 0.0450 & 0.0645 & 0.0636 & 0.0487 & 0.015 & 30 \\
\hline PCB 95+121 & $<\mathrm{LOD}$ & $<\mathrm{LOD}$ & $<\mathrm{LOD}$ & $<\mathrm{LOD}$ & $<\mathrm{LOD}$ & $<$ LOD & & \\
\hline РCB 99 & 6.17 & 4.36 & 3.97 & 5.81 & 5.43 & 5.15 & 0.94 & 18 \\
\hline PCB 101 & $<\mathrm{LOD}$ & $<\mathrm{LOD}$ & $<\mathrm{LOD}$ & $<\mathrm{LOD}$ & $<\mathrm{LOD}$ & $<$ LOD & & \\
\hline PCB 105 & 1.78 & 1.65 & 1.22 & 1.97 & 1.36 & 1.60 & 0.30 & 19 \\
\hline PCB 106 & 0.00986 & 0.0264 & 0.0298 & $<\mathrm{LOQ}$ & 0.00971 & 0.0189 & 0.011 & 56 \\
\hline PCB 107 & 0.363 & 0.308 & 0.288 & 0.358 & 0.332 & 0.330 & 0.032 & 9.7 \\
\hline PCB 110 & $<\mathrm{LOD}$ & $<\mathrm{LOD}$ & $<\mathrm{LOD}$ & $<\mathrm{LOD}$ & $<\mathrm{LOD}$ & $<$ LOD & & \\
\hline PCB 112 & $<\mathrm{LOD}$ & $<\mathrm{LOD}$ & $<\mathrm{LOD}$ & $<\mathrm{LOD}$ & $<\mathrm{LOD}$ & $<$ LOD & & \\
\hline PCB 114 & 0.220 & 0.183 & 0.145 & 0.225 & 0.183 & 0.191 & 0.033 & 17 \\
\hline PCB 118 & 6.81 & 5.49 & 4.59 & 7.13 & 6.08 & 6.02 & 1.0 & 17 \\
\hline PCB 119 & 0.156 & 0.0828 & 0.0896 & 0.117 & 0.134 & 0.116 & 0.030 & 26 \\
\hline PCB 127 & 2.18 & $<\mathrm{LOD}$ & $<\mathrm{LOD}$ & $<\mathrm{LOD}$ & $<\mathrm{LOD}$ & $<$ LOD & & \\
\hline PCB 128 & 0.818 & 0.593 & 0.506 & 0.804 & 0.824 & 0.709 & 0.15 & 21 \\
\hline PCB 130 & 0.334 & 0.221 & 0.170 & 0.304 & 0.334 & 0.273 & 0.073 & 27 \\
\hline PCB 137 & 0.295 & 0.192 & 0.142 & 0.245 & 0.308 & 0.236 & 0.070 & 30 \\
\hline PCB 138 & 5.74 & 4.13 & 3.29 & 5.32 & 5.56 & 4.81 & 1.1 & 22 \\
\hline PCB 146 & 2.60 & 2.32 & 1.83 & 3.01 & 2.54 & 2.46 & 0.43 & 18 \\
\hline РCB 149 & 0.359 & 0.297 & 0.256 & 0.331 & 0.368 & 0.322 & 0.046 & 14 \\
\hline
\end{tabular}


Appendix 34 (Continued).

\begin{tabular}{|c|c|c|c|c|c|c|c|c|}
\hline Compound & 1278 & 1279 & 1281 & 1284 & 1287 & Mean & SD & RSD \\
\hline PCB 151 & $<\mathrm{LOQ}$ & $<\mathrm{LOQ}$ & $<\mathrm{LOQ}$ & $<\mathrm{LOQ}$ & $<\mathrm{LOQ}$ & $<$ LOQ & & \\
\hline РCB $153+132$ & 13.0 & 10.2 & 7.97 & 13.4 & 13.0 & 11.5 & 2.3 & 20 \\
\hline РCB 154 & 0.106 & 0.0703 & 0.0741 & 0.0775 & 0.117 & 0.0890 & 0.021 & 24 \\
\hline PCB 156 & 0.493 & 0.432 & 0.385 & 0.572 & 0.444 & 0.465 & 0.071 & 15 \\
\hline PCB 157 & 0.138 & 0.124 & 0.114 & 0.175 & 0.130 & 0.136 & 0.024 & 17 \\
\hline PCB 158 & 0.254 & 0.126 & 0.133 & 0.207 & 0.242 & 0.192 & 0.060 & 31 \\
\hline PCB 159 & $<\mathrm{LOQ}$ & $<\mathrm{LOQ}$ & $<$ LOQ & $<\mathrm{LOQ}$ & $<$ LOQ & $<$ LOQ & & \\
\hline PCB 163 & 2.16 & 1.73 & 1.42 & 2.39 & 2.27 & 1.99 & 0.41 & 20 \\
\hline PCB 165 & 0.0164 & 0.0263 & 0.0274 & 0.0253 & 0.0133 & 0.0217 & 0.0064 & 29 \\
\hline PCB 166 & 0.0405 & 0.0439 & 0.0470 & 0.0529 & 0.0381 & 0.0445 & 0.0058 & 13 \\
\hline PCB 167 & 0.268 & 0.252 & 0.168 & 0.296 & 0.246 & 0.246 & 0.048 & 19 \\
\hline PCB 170 & 0.846 & 0.718 & 0.582 & 0.904 & 0.856 & 0.781 & 0.13 & 17 \\
\hline PCB 172 & 0.292 & 0.315 & 0.197 & 0.313 & 0.285 & 0.281 & 0.048 & 17 \\
\hline PCB 174 & 0.0303 & 0.0311 & 0.0324 & 0.0454 & 0.0401 & 0.0358 & 0.0066 & 18 \\
\hline PCB 175 & 0.0712 & 0.0625 & 0.0406 & 0.0714 & 0.0668 & 0.0625 & 0.013 & 20 \\
\hline PCB 176 & 0.00714 & 0.00913 & 0.0118 & 0.00763 & 0.00537 & 0.00821 & 0.0024 & 29 \\
\hline PCB 177 & 0.272 & 0.126 & 0.118 & 0.203 & 0.299 & 0.204 & 0.082 & 40 \\
\hline PCB 178 & 0.278 & 0.136 & 0.122 & 0.299 & 0.220 & 0.211 & 0.081 & 38 \\
\hline PCB $180+193$ & 2.26 & 1.70 & 1.35 & 2.20 & 2.44 & 1.99 & 0.45 & 23 \\
\hline РCB 183 & 0.571 & 0.562 & 0.373 & 0.627 & 0.510 & 0.529 & 0.096 & 18 \\
\hline PCB 185 & 0.0323 & 0.0263 & 0.0210 & 0.0253 & 0.0296 & 0.0269 & 0.0043 & 16 \\
\hline PCB 187 & 2.45 & 2.28 & 1.41 & 2.89 & 2.63 & 2.33 & 0.56 & 24 \\
\hline PCB 188 & 0.0214 & 0.0245 & 0.0189 & 0.0131 & 0.0147 & 0.0185 & 0.0047 & 25 \\
\hline PCB 189 & 0.0606 & 0.0518 & 0.0199 & 0.0636 & 0.0607 & 0.0513 & 0.018 & 35 \\
\hline PCB 191 & 0.0301 & 0.0221 & 0.0187 & 0.0170 & 0.0354 & 0.0247 & 0.0078 & 32 \\
\hline PCB 194 & 0.182 & 0.162 & 0.155 & 0.268 & 0.232 & 0.200 & 0.049 & 24 \\
\hline PCB 195 & 0.0823 & 0.0983 & 0.0763 & 0.121 & 0.110 & 0.0976 & 0.019 & 19 \\
\hline PCB 196 & 0.698 & 0.687 & 0.610 & 0.787 & 0.734 & 0.703 & 0.065 & 9.2 \\
\hline PCB 197 & 0.0617 & 0.0680 & 0.0336 & 0.0510 & 0.0648 & 0.0558 & 0.014 & 25 \\
\hline PCB 199 & 2.56 & 2.60 & 2.06 & 3.15 & 2.72 & 2.62 & 0.39 & 15 \\
\hline PCB 200 & $<\mathrm{LOD}$ & $<\mathrm{LOD}$ & $<\mathrm{LOD}$ & $<\mathrm{LOD}$ & $<\mathrm{LOD}$ & $<$ LOD & & \\
\hline PCB 201 & 0.747 & 0.896 & 0.648 & 1.12 & 0.786 & 0.839 & 0.18 & 21 \\
\hline PCB 202 & 0.0530 & 0.0420 & 0.0504 & 0.0368 & 0.0378 & 0.0440 & 0.0073 & 17 \\
\hline PCB 205 & 0.0320 & 0.0492 & 0.0426 & 0.0248 & 0.0475 & 0.0392 & 0.010 & 27 \\
\hline PCB 206 & 0.183 & 0.178 & 0.314 & 0.174 & 0.356 & 0.241 & 0.087 & 36 \\
\hline PCB 207 & 0.0582 & 0.0615 & 0.0510 & 0.0824 & 0.0660 & 0.0638 & 0.012 & 18 \\
\hline PCB 208 & 0.0855 & 0.119 & 0.166 & 0.105 & 0.171 & 0.129 & 0.038 & 29 \\
\hline PCB 209 & 0.102 & 0.133 & 0.0873 & 0.230 & 0.118 & 0.134 & 0.056 & 42 \\
\hline
\end{tabular}


Appendix 35. Brominated diphenyl ether (BDE) and polychlorinated biphenyl (PCB) mass fractions ( $\mathrm{ng} \mathrm{g}^{-1}$ wet mass) in common murre eggs collected at Sledge Island, Alaska in 2008 (compounds shown in red and blue were above and below reference value ranges, respectively).

\begin{tabular}{|c|c|c|c|c|c|c|c|c|}
\hline Compound & 1292 & 1295 & 1301 & 1303 & 1305 & Mean & SD & RSD \\
\hline BDE47 & 0.739 & 0.839 & 0.753 & 0.665 & 1.10 & 0.819 & 0.17 & 20 \\
\hline BDE99 & $<\mathrm{LOQ}$ & $<\mathrm{LOQ}$ & $<\mathrm{LOQ}$ & 0.988 & 1.25 & 1.12 & 0.18 & 17 \\
\hline BDE100 & 0.600 & 0.601 & 0.635 & 0.679 & 0.845 & 0.672 & 0.10 & 15 \\
\hline PCB 8 & $<\mathrm{LOD}$ & 0.0401 & 0.0316 & 0.0955 & 0.0945 & 0.0654 & 0.034 & 52 \\
\hline PCB 18 & $<\mathrm{LOD}$ & $<\mathrm{LOD}$ & 0.0103 & $<\mathrm{LOD}$ & $<\mathrm{LOD}$ & $<$ LOD & & \\
\hline PCB 28+31 & 2.21 & 3.02 & 2.37 & 3.10 & 4.06 & 2.95 & 0.73 & 25 \\
\hline PCB 29 & $<\mathrm{LOQ}$ & $<$ LOQ & $<\mathrm{LOQ}$ & $<$ LOQ & $<$ LOQ & $<$ LOQ & & \\
\hline PCB 44 & 0.0622 & 0.0643 & 0.110 & 0.0989 & 0.0633 & 0.0797 & 0.023 & 29 \\
\hline PCB 45 & $<\mathrm{LOQ}$ & $<\mathrm{LOQ}$ & 0.0683 & $<\mathrm{LOQ}$ & 0.0645 & 0.0664 & 0.0027 & 4.0 \\
\hline РCB 49 & 0.0892 & 0.0726 & 0.138 & 0.163 & 0.351 & 0.163 & 0.11 & 68 \\
\hline PCB 52 & 0.188 & 0.105 & 0.234 & 0.284 & 0.318 & 0.226 & 0.084 & 37 \\
\hline PCB 56 & $<\mathrm{LOQ}$ & $<\mathrm{LOQ}$ & 0.0229 & $<\mathrm{LOQ}$ & $<\mathrm{LOQ}$ & $<$ LOQ & & \\
\hline РCB 63 & $<\mathrm{LOQ}$ & $<$ LOQ & 0.201 & $<$ LOQ & 0.227 & 0.214 & 0.018 & 8.4 \\
\hline PCB 66 & 1.88 & 2.58 & 2.07 & 2.28 & 2.98 & 2.36 & 0.43 & 18 \\
\hline PCB 70 & 0.0894 & 0.0478 & 0.147 & 0.159 & 0.198 & 0.128 & 0.060 & 46 \\
\hline РCB 74 & 1.57 & 2.08 & 1.66 & 1.90 & 2.66 & 1.98 & 0.43 & 22 \\
\hline РCB 79 & $<\mathrm{LOQ}$ & $<\mathrm{LOQ}$ & $<\mathrm{LOQ}$ & $<$ LOQ & $<\mathrm{LOQ}$ & $<\mathrm{LOQ}$ & & \\
\hline PCB 82 & $<\mathrm{LOD}$ & $<\mathrm{LOD}$ & 0.0580 & 0.00375 & 0.0162 & 0.0260 & 0.028 & 110 \\
\hline PCB 87 & 0.0700 & 0.0451 & 0.113 & 0.137 & 0.361 & 0.145 & 0.13 & 87 \\
\hline РCB 92 & 0.0657 & 0.0434 & 0.132 & 0.101 & 0.103 & 0.0891 & 0.035 & 39 \\
\hline PCB 95+121 & $<\mathrm{LOD}$ & $<\mathrm{LOD}$ & 0.0709 & $<\mathrm{LOD}$ & $<\mathrm{LOD}$ & $<$ LOD & & \\
\hline PCB 99 & 3.64 & 5.56 & 3.69 & 4.88 & 8.51 & 5.26 & 2.0 & 38 \\
\hline PCB 101 & 0.0700 & $<\mathrm{LOD}$ & 0.146 & 0.199 & 2.13 & 0.635 & 1.0 & 160 \\
\hline PCB 105 & 1.10 & 2.01 & 1.30 & 1.36 & 2.03 & 1.56 & 0.43 & 28 \\
\hline PCB 106 & 0.0254 & 0.0239 & 0.0681 & 0.0310 & 0.0125 & 0.0322 & 0.021 & 66 \\
\hline PCB 107 & 0.233 & 0.305 & 0.366 & 0.236 & 0.468 & 0.321 & 0.099 & 31 \\
\hline PCB 110 & $<\mathrm{LOD}$ & $<\mathrm{LOD}$ & $<\mathrm{LOD}$ & $<\mathrm{LOD}$ & 0.672 & $<$ LOD & & \\
\hline PCB 112 & $<\mathrm{LOD}$ & $<\mathrm{LOD}$ & 0.0528 & $<$ LOD & $<\mathrm{LOD}$ & $<$ LOD & & \\
\hline PCB 114 & 0.154 & 0.230 & 0.224 & 0.188 & 0.263 & 0.212 & 0.042 & 20 \\
\hline PCB 118 & 4.54 & 7.13 & 4.88 & 5.57 & 8.85 & 6.20 & 1.8 & 29 \\
\hline PCB 119 & 0.0956 & 0.113 & 0.124 & 0.123 & 0.244 & 0.140 & 0.059 & 42 \\
\hline PCB 127 & $<\mathrm{LOD}$ & $<\mathrm{LOD}$ & $<\mathrm{LOD}$ & $<\mathrm{LOD}$ & $<\mathrm{LOD}$ & $<$ LOD & & \\
\hline PCB 128 & 0.626 & 0.919 & 0.641 & 0.757 & 1.56 & 0.901 & 0.39 & 43 \\
\hline PCB 130 & 0.200 & 0.268 & 0.322 & 0.299 & 0.837 & 0.385 & 0.26 & 67 \\
\hline PCB 137 & 0.249 & 0.287 & 0.265 & 0.271 & 0.659 & 0.346 & 0.18 & 51 \\
\hline PCB 138 & 4.38 & 6.27 & 4.11 & 4.97 & 10.1 & 5.97 & 2.5 & 41 \\
\hline PCB 146 & 2.02 & 2.97 & 2.10 & 2.42 & 3.73 & 2.65 & 0.71 & 27 \\
\hline PCB 149 & 0.361 & 0.309 & 0.401 & 0.497 & 1.34 & 0.582 & 0.43 & 74 \\
\hline
\end{tabular}


Appendix 35 (Continued).

\begin{tabular}{|c|c|c|c|c|c|c|c|c|}
\hline Compound & 1292 & 1295 & 1301 & 1303 & 1305 & Mean & SD & RSD \\
\hline PCB 151 & 0.0781 & 0.0763 & 0.126 & 0.0898 & 0.102 & 0.0946 & 0.021 & 22 \\
\hline PCB $153+132$ & 10.3 & 14.8 & 9.97 & 12.4 & 23.8 & 14.3 & 5.7 & 40 \\
\hline PCB 154 & 0.102 & 0.0955 & 0.154 & 0.126 & 0.387 & 0.173 & 0.12 & 70 \\
\hline PCB 156 & 0.383 & 0.615 & 0.471 & 0.421 & 0.620 & 0.502 & 0.11 & 22 \\
\hline PCB 157 & 0.121 & 0.175 & 0.195 & 0.141 & 0.197 & 0.166 & 0.034 & 20 \\
\hline PCB 158 & 0.236 & 0.398 & 0.350 & 0.343 & 0.904 & 0.446 & 0.26 & 59 \\
\hline PCB 159 & $<$ LOQ & $<\mathrm{LOQ}$ & 0.0570 & $<\mathrm{LOQ}$ & $<\mathrm{LOQ}$ & $<\mathbf{L O Q}$ & & \\
\hline PCB 163 & 1.66 & 2.17 & 1.83 & 1.98 & 3.13 & 2.15 & 0.58 & 27 \\
\hline PCB 165 & 0.0208 & 0.0213 & 0.0574 & 0.0144 & 0.0366 & 0.0301 & 0.017 & 58 \\
\hline PCB 166 & 0.0397 & 0.0496 & 0.135 & 0.0388 & 0.0776 & 0.0681 & 0.041 & 60 \\
\hline PCB 167 & 0.192 & 0.325 & 0.335 & 0.241 & 0.428 & 0.304 & 0.091 & 30 \\
\hline PCB 170 & 0.888 & 1.07 & 0.888 & 0.931 & 1.65 & 1.09 & 0.33 & 30 \\
\hline PCB 172 & 0.251 & 0.314 & 0.345 & 0.318 & 0.432 & 0.332 & 0.066 & 20 \\
\hline PCB 174 & 0.0431 & 0.0539 & 0.103 & 0.0686 & 0.122 & 0.0781 & 0.033 & 43 \\
\hline PCB 175 & 0.0635 & 0.0872 & 0.150 & 0.0753 & 0.140 & 0.103 & 0.039 & 38 \\
\hline PCB 176 & 0.0167 & 0.0138 & 0.0869 & 0.0151 & 0.0221 & 0.0309 & 0.031 & 100 \\
\hline PCB 177 & 0.206 & 0.155 & 0.203 & 0.266 & 0.970 & 0.360 & 0.34 & 95 \\
\hline PCB 178 & 0.191 & 0.370 & 0.207 & 0.216 & 0.695 & 0.336 & 0.21 & 63 \\
\hline PCB 180+193 & 2.15 & 2.64 & 2.14 & 2.40 & 4.57 & 2.78 & 1.0 & 37 \\
\hline PCB 183 & 0.526 & 0.706 & 0.583 & 0.591 & 1.79 & 0.839 & 0.53 & 64 \\
\hline PCB 185 & 0.0273 & 0.0175 & 0.0905 & 0.0229 & 0.0488 & 0.0414 & 0.030 & 72 \\
\hline PCB 187 & 1.93 & 2.78 & 1.91 & 2.48 & 5.65 & 2.95 & 1.6 & 53 \\
\hline PCB 188 & 0.0141 & 0.0289 & 0.0738 & 0.0171 & 0.0347 & 0.0337 & 0.024 & 71 \\
\hline PCB 189 & 0.0458 & $<\mathrm{LOQ}$ & 0.108 & 0.0200 & 0.0205 & 0.0486 & 0.041 & 85 \\
\hline PCB 191 & 0.0135 & 0.0381 & 0.0544 & 0.0197 & 0.0521 & 0.0355 & 0.019 & 52 \\
\hline PCB 194 & 0.225 & 0.339 & 0.353 & 0.237 & 0.409 & 0.312 & 0.079 & 25 \\
\hline PCB 195 & 0.147 & 0.159 & 0.227 & 0.132 & 0.211 & 0.175 & 0.042 & 24 \\
\hline PCB 196 & 0.715 & 0.863 & 0.790 & 0.826 & 1.00 & 0.839 & 0.11 & 13 \\
\hline РCB 197 & 0.0409 & 0.0531 & 0.121 & 0.0579 & 0.0698 & 0.0686 & 0.031 & 46 \\
\hline РСВ 199 & 2.41 & 3.29 & 2.69 & 2.92 & 3.64 & 2.99 & 0.49 & 16 \\
\hline PCB 200 & $<\mathrm{LOD}$ & $<\mathrm{LOD}$ & 0.00357 & $<\mathrm{LOD}$ & $<\mathrm{LOD}$ & $<$ LOD & & \\
\hline РCB 201 & 0.899 & 1.08 & 1.39 & 0.924 & 1.19 & 1.10 & 0.20 & 19 \\
\hline PCB 202 & $<\mathrm{LOQ}$ & 0.0608 & 0.104 & 0.0587 & 0.217 & 0.110 & 0.074 & 67 \\
\hline PCB 205 & 0.0104 & 0.0605 & 0.0927 & 0.0232 & 0.0488 & 0.0471 & 0.032 & 69 \\
\hline PCB 206 & 0.121 & 0.436 & 0.321 & 0.285 & 0.385 & 0.310 & 0.12 & 39 \\
\hline PCB 207 & 0.0378 & 0.0685 & 0.0866 & 0.0490 & 0.0874 & 0.0659 & 0.022 & 34 \\
\hline PCB 208 & 0.0620 & 0.137 & 0.122 & 0.140 & 0.184 & 0.129 & 0.044 & 34 \\
\hline PCB 209 & 0.0938 & 0.160 & 0.196 & 0.110 & 0.196 & 0.151 & 0.048 & 32 \\
\hline
\end{tabular}


Appendix 36. Brominated diphenyl ether (BDE) and polychlorinated biphenyl (PCB) mass fractions (ng g ${ }^{-1}$ wet mass) in common murre eggs collected at Bluff, Alaska in 2008 (compounds shown in red and blue were above and below reference value ranges, respectively).

\begin{tabular}{|c|c|c|c|c|c|c|c|c|}
\hline Compound & 1307 & 1309 & 1314 & 1319 & 1320 & Mean & SD & RSD \\
\hline BDE47 & 0.801 & 0.641 & 0.357 & 0.676 & 1.05 & 0.704 & 0.25 & 36 \\
\hline BDE99 & 1.06 & $<\mathrm{LOQ}$ & $<$ LOQ & $<\mathrm{LOQ}$ & 0.935 & 0.998 & 0.089 & 8.9 \\
\hline BDE100 & 0.818 & 0.570 & 0.538 & 0.595 & 0.740 & 0.652 & 0.12 & 19 \\
\hline PCB 8 & $<\mathrm{LOD}$ & 0.0445 & 0.0310 & 0.0625 & 0.0313 & 0.0423 & 0.015 & 35 \\
\hline PCB 18 & $<\mathrm{LOD}$ & $<\mathrm{LOD}$ & $<\mathrm{LOD}$ & $<$ LOD & $<\mathrm{LOD}$ & $<$ LOD & & \\
\hline PCB $28+31$ & 4.20 & 2.52 & 2.66 & 2.27 & 2.64 & 2.86 & 0.76 & 27 \\
\hline PCB 29 & $<$ LOQ & $<\mathrm{LOQ}$ & $<\mathrm{LOQ}$ & $<$ LOQ & $<\mathrm{LOQ}$ & $<\mathrm{LOQ}$ & & \\
\hline PCB 44 & 0.0553 & $<\mathrm{LOQ}$ & $<\mathrm{LOQ}$ & 0.0455 & 0.0461 & 0.0490 & 0.0055 & 11 \\
\hline PCB 45 & $<$ LOQ & $<\mathrm{LOQ}$ & 0.0294 & $<$ LOQ & $<\mathrm{LOQ}$ & $<$ LOQ & & \\
\hline РCB 49 & 0.0848 & 0.207 & 0.0617 & 0.0696 & 0.0848 & 0.102 & 0.060 & 59 \\
\hline PCB 52 & 0.0929 & 0.120 & 0.0564 & 0.102 & 0.0801 & 0.0903 & 0.024 & 27 \\
\hline РCB 56 & 1.10 & $<\mathrm{LOQ}$ & $<\mathrm{LOQ}$ & $<$ LOQ & $<\mathrm{LOQ}$ & $<\mathrm{LOQ}$ & & \\
\hline PCB 63 & 0.230 & $<\mathrm{LOQ}$ & $<$ LOQ & $<$ LOQ & $<\mathrm{LOQ}$ & $<\mathrm{LOQ}$ & & \\
\hline РCB 66 & 3.27 & 1.93 & 2.35 & 1.72 & 2.10 & 2.27 & 0.60 & 27 \\
\hline РCB 70 & 0.0132 & 0.103 & 0.0265 & 0.0438 & 0.0269 & 0.0427 & 0.035 & 83 \\
\hline РCB 74 & 2.70 & 1.66 & 1.87 & 1.43 & 1.82 & 1.90 & 0.48 & 25 \\
\hline РCB 79 & $<\mathrm{LOQ}$ & $<\mathrm{LOQ}$ & $<\mathrm{LOQ}$ & $<$ LOQ & $<\mathrm{LOQ}$ & $<\mathrm{LOQ}$ & & \\
\hline РCB 82 & $<$ LOD & 0.00448 & 0.00513 & $<\mathrm{LOD}$ & $<\mathrm{LOD}$ & 0.00480 & 0.00046 & 9.6 \\
\hline РCB 87 & 0.141 & 0.244 & 0.0476 & 0.0877 & 0.105 & 0.125 & 0.074 & 59 \\
\hline РCB 92 & 0.0423 & 0.0511 & 0.0468 & 0.0798 & 0.0588 & 0.0558 & 0.015 & 26 \\
\hline PCB 95+121 & 0.0247 & $<\mathrm{LOD}$ & $<\mathrm{LOD}$ & $<\mathrm{LOD}$ & $<\mathrm{LOD}$ & $<$ LOD & & \\
\hline РCB 99 & 8.73 & 5.18 & 4.96 & 4.04 & 5.38 & 5.66 & 1.8 & 32 \\
\hline PCB 101 & 0.0383 & 1.52 & $<\mathrm{LOD}$ & 0.0843 & 0.0612 & 0.426 & 0.73 & 170 \\
\hline PCB 105 & 2.47 & 1.18 & 1.83 & 0.964 & 1.21 & 1.53 & 0.62 & 40 \\
\hline PCB 106 & 0.0417 & $<$ LOQ & $<\mathrm{LOQ}$ & $<$ LOQ & $<$ LOQ & $<\mathrm{LOQ}$ & & \\
\hline PCB 107 & 0.519 & 0.272 & 0.338 & 0.262 & 0.376 & 0.353 & 0.10 & 29 \\
\hline PCB 110 & $<$ LOD & 0.123 & $<\mathrm{LOD}$ & $<\mathrm{LOD}$ & $<\mathrm{LOD}$ & $<$ LOD & & \\
\hline PCB 112 & $<\mathrm{LOD}$ & $<\mathrm{LOD}$ & $<\mathrm{LOD}$ & $<\mathrm{LOD}$ & $<\mathrm{LOD}$ & $<$ LOD & & \\
\hline PCB 114 & 0.262 & 0.150 & 0.246 & 0.141 & 0.171 & 0.194 & 0.056 & 29 \\
\hline PCB 118 & 9.77 & 5.36 & 6.57 & 4.47 & 5.63 & 6.36 & 2.0 & 32 \\
\hline PCB 119 & 0.221 & 0.145 & 0.0966 & 0.107 & 0.136 & 0.141 & 0.049 & 35 \\
\hline PCB 127 & $<$ LOD & $<\mathrm{LOD}$ & $<\mathrm{LOD}$ & $<\mathrm{LOD}$ & $<\mathrm{LOD}$ & $<$ LOD & & \\
\hline PCB 128 & 1.44 & 0.972 & 0.812 & 0.713 & 0.902 & 0.968 & 0.28 & 29 \\
\hline PCB 130 & 0.570 & 0.459 & 0.241 & 0.260 & 0.376 & 0.381 & 0.14 & 36 \\
\hline PCB 137 & 0.455 & 0.402 & 0.240 & 0.231 & 0.339 & 0.333 & 0.098 & 30 \\
\hline PCB 138 & 9.81 & 6.51 & 5.33 & 4.28 & 6.01 & 6.39 & 2.1 & 33 \\
\hline PCB 146 & 4.45 & 2.33 & 3.00 & 2.03 & 2.50 & 2.86 & 0.96 & 33 \\
\hline PCB 149 & 0.417 & 0.755 & 0.289 & 0.388 & 0.377 & 0.445 & 0.18 & 40 \\
\hline
\end{tabular}


Appendix 36 (Continued).

\begin{tabular}{|c|c|c|c|c|c|c|c|c|}
\hline Compound & 1307 & 1309 & 1314 & 1319 & 1320 & Mean & SD & RSD \\
\hline PCB 151 & 0.0971 & $<\mathrm{LOQ}$ & $<\mathrm{LOQ}$ & 0.0781 & $<\mathrm{LOQ}$ & 0.0876 & 0.013 & 15 \\
\hline PCB $153+132$ & 23.9 & 15.1 & 13.9 & 10.8 & 14.8 & 15.7 & 4.9 & 31 \\
\hline PCB 154 & 0.158 & 0.256 & 0.0966 & 0.108 & 0.144 & 0.153 & 0.063 & 41 \\
\hline PCB 156 & 0.816 & 0.373 & 0.658 & 0.401 & 0.444 & 0.538 & 0.19 & 36 \\
\hline PCB 157 & 0.271 & 0.105 & 0.180 & 0.117 & 0.128 & 0.160 & 0.068 & 43 \\
\hline PCB 158 & 0.429 & 0.564 & 0.164 & 0.280 & 0.319 & 0.351 & 0.15 & 43 \\
\hline PCB 159 & 0.0136 & $<\mathrm{LOQ}$ & $<\mathrm{LOQ}$ & $<\mathrm{LOQ}$ & $<\mathrm{LOQ}$ & $<\mathbf{L O Q}$ & & \\
\hline PCB 163 & 3.67 & 2.06 & 2.42 & 1.73 & 2.35 & 2.45 & 0.74 & 30 \\
\hline PCB 165 & 0.0339 & 0.0190 & 0.0286 & 0.0196 & 0.0206 & 0.0243 & 0.0066 & 27 \\
\hline PCB 166 & 0.0815 & 0.0468 & 0.0655 & 0.0374 & 0.0379 & 0.0538 & 0.019 & 36 \\
\hline PCB 167 & 0.499 & 0.256 & 0.336 & 0.192 & 0.251 & $\mathbf{0 . 3 0 7}$ & 0.12 & 39 \\
\hline PCB 170 & 1.88 & 0.999 & 1.27 & 0.974 & 1.07 & 1.24 & 0.38 & 30 \\
\hline PCB 172 & 0.533 & 0.254 & 0.419 & 0.274 & 0.309 & 0.358 & 0.12 & 33 \\
\hline PCB 174 & 0.0951 & 0.126 & 0.0694 & 0.0463 & 0.0443 & 0.0762 & 0.034 & 45 \\
\hline PCB 175 & 0.0958 & 0.105 & 0.0839 & 0.0637 & 0.0830 & 0.0862 & 0.015 & 18 \\
\hline PCB 176 & $<\mathrm{LOQ}$ & 0.0101 & 0.0129 & 0.0102 & $<$ LOQ & 0.0111 & 0.0016 & 14 \\
\hline PCB 177 & 0.449 & 0.644 & 0.152 & 0.235 & 0.380 & 0.372 & 0.19 & 52 \\
\hline PCB 178 & 0.427 & 0.295 & 0.284 & 0.223 & 0.343 & 0.314 & 0.076 & 24 \\
\hline PCB $180+193$ & 4.34 & 2.96 & 2.66 & 2.32 & 2.95 & 3.05 & 0.77 & 25 \\
\hline PCB 183 & 1.17 & 1.08 & 0.814 & 0.571 & 0.698 & 0.867 & 0.25 & 29 \\
\hline PCB 185 & 0.0347 & 0.0432 & 0.0274 & 0.0334 & 0.0457 & 0.0369 & 0.0075 & 20 \\
\hline PCB 187 & 5.14 & 3.17 & 2.83 & 2.10 & 2.82 & 3.21 & 1.1 & 36 \\
\hline PCB 188 & 0.0460 & 0.0116 & 0.0267 & 0.0206 & 0.0178 & 0.0245 & 0.013 & 54 \\
\hline PCB 189 & 0.0266 & $<\mathrm{LOQ}$ & 0.0713 & $<\mathrm{LOQ}$ & $<\mathrm{LOQ}$ & 0.0490 & 0.032 & 64 \\
\hline PCB 191 & 0.0534 & 0.0405 & 0.0328 & 0.0246 & 0.0213 & 0.0345 & 0.013 & 37 \\
\hline PCB 194 & 0.627 & 0.242 & 0.507 & 0.296 & 0.293 & 0.393 & 0.17 & 42 \\
\hline PCB 195 & 0.283 & 0.104 & 0.225 & 0.151 & 0.148 & 0.182 & 0.071 & 39 \\
\hline PCB 196 & 1.28 & 0.666 & 0.969 & 0.730 & 0.844 & 0.897 & 0.24 & 27 \\
\hline PCB 197 & 0.135 & 0.0572 & 0.0808 & 0.0784 & 0.0807 & 0.0864 & 0.029 & 33 \\
\hline PCB 199 & 5.14 & 2.32 & 4.01 & 2.56 & 3.09 & 3.43 & 1.2 & 34 \\
\hline PCB 200 & $<\mathrm{LOD}$ & $<\mathrm{LOD}$ & $<\mathrm{LOD}$ & $<\mathrm{LOD}$ & $<\mathrm{LOD}$ & $<$ LOD & & \\
\hline PCB 201 & 1.73 & 0.693 & 1.26 & 1.01 & 1.01 & 1.14 & 0.38 & 34 \\
\hline PCB 202 & 0.0826 & 0.0966 & 0.0630 & 0.0639 & 0.0837 & 0.0780 & 0.014 & 18 \\
\hline PCB 205 & 0.0485 & 0.0147 & 0.0281 & 0.0313 & 0.0344 & 0.0314 & 0.012 & 39 \\
\hline PCB 206 & 0.370 & 0.197 & 0.361 & 0.179 & 0.767 & 0.375 & 0.24 & 63 \\
\hline PCB 207 & 0.143 & 0.0498 & 0.116 & 0.0599 & 0.0642 & 0.0866 & 0.041 & 47 \\
\hline PCB 208 & 0.187 & 0.116 & 0.127 & 0.0427 & 0.0806 & 0.111 & 0.054 & 49 \\
\hline PCB 209 & 0.262 & 0.106 & 0.200 & 0.0923 & 0.135 & 0.159 & 0.071 & 45 \\
\hline
\end{tabular}


Appendix 37. Brominated diphenyl ether (BDE) and polychlorinated biphenyl (PCB) mass fractions (ng g ${ }^{-1}$ wet mass) in common murre eggs collected at Cape Denbigh, Alaska in 2009 (compounds shown in red and blue were above and below reference value ranges, respectively).

\begin{tabular}{|c|c|c|c|c|c|c|c|c|}
\hline Compound & 1443 & 1446 & 1448 & 1449 & 1452 & Mean & SD & RSD \\
\hline BDE47 & 0.726 & 0.458 & 0.524 & 0.320 & 0.580 & 0.522 & 0.15 & 29 \\
\hline BDE99 & 0.141 & $<$ LOQ & 0.0993 & $<$ LOQ & 0.163 & 0.134 & 0.032 & 24 \\
\hline BDE100 & 0.210 & 0.165 & 0.190 & 0.124 & 0.240 & 0.186 & 0.044 & 24 \\
\hline PCB 8 & $<\mathrm{LOD}$ & 0.00688 & 0.0375 & 0.0147 & $<\mathrm{LOD}$ & 0.0197 & 0.016 & 81 \\
\hline PCB 18 & $<\mathrm{LOD}$ & $<\mathrm{LOD}$ & $<$ LOD & $<\mathrm{LOD}$ & $<$ LOD & $<$ LOD & & \\
\hline PCB28+31 & 1.27 & 1.60 & 2.07 & 1.70 & 1.74 & 1.67 & 0.29 & 17 \\
\hline PCB 29 & $<\mathrm{LOD}$ & $<\mathrm{LOD}$ & $<\mathrm{LOD}$ & $<\mathrm{LOD}$ & $<\mathrm{LOD}$ & $<$ LOD & & \\
\hline PCB 44 & $<$ LOQ & $<$ LOQ & $<$ LOQ & $<\mathrm{LOQ}$ & $<$ LOQ & $<\mathrm{LOQ}$ & & \\
\hline PCB 45 & $<\mathrm{LOQ}$ & $<$ LOQ & $<$ LOQ & $<$ LOQ & $<$ LOQ & $<\mathrm{LOQ}$ & & \\
\hline PCB 49 & 0.0661 & 0.0500 & 0.0700 & 0.0455 & 0.0429 & 0.0549 & 0.012 & 23 \\
\hline PCB 52 & 0.154 & 0.149 & 0.196 & 0.125 & 0.196 & 0.164 & 0.031 & 19 \\
\hline PCB 56 & 0.151 & 0.180 & 0.196 & 0.197 & 0.177 & 0.180 & 0.019 & 10 \\
\hline РCB 63 & 0.0796 & 0.0992 & 0.125 & 0.0680 & 0.109 & 0.0962 & 0.023 & 24 \\
\hline PCB 66 & 1.00 & 1.29 & 1.46 & 1.45 & 1.29 & 1.30 & 0.19 & 14 \\
\hline PCB 70 & 0.0708 & 0.0663 & 0.0735 & 0.0509 & 0.0694 & 0.0662 & 0.0089 & 13 \\
\hline PCB 74 & 0.791 & 0.920 & 1.13 & 1.01 & 1.14 & 0.999 & 0.15 & 15 \\
\hline РCB 79 & 0.0254 & $<$ LOQ & $<$ LOQ & 0.0287 & 0.0370 & 0.0304 & 0.006 & 20 \\
\hline PCB 82 & 0.0303 & 0.0353 & 0.0300 & $<\mathrm{LOQ}$ & $<$ LOQ & 0.0319 & 0.0029 & 9.3 \\
\hline PCB 87 & 0.0256 & 0.0637 & 0.110 & 0.0228 & 0.0832 & 0.0611 & 0.037 & 61 \\
\hline PCB 92 & 0.0936 & 0.0897 & 0.114 & 0.0886 & 0.0859 & 0.0943 & 0.011 & 12 \\
\hline PCB 95+121 & $<\mathrm{LOD}$ & $<\mathrm{LOD}$ & 0.0243 & $<\mathrm{LOD}$ & $<\mathrm{LOD}$ & $<$ LOD & & \\
\hline PCB 99 & 2.75 & 2.74 & 4.32 & 3.03 & 3.97 & 3.36 & 0.73 & 22 \\
\hline PCB 101 & 0.227 & 0.197 & 0.287 & 0.155 & 0.263 & 0.226 & 0.052 & 23 \\
\hline PCB 105 & 0.849 & 0.974 & 1.22 & 1.31 & 1.11 & 1.09 & 0.18 & 17 \\
\hline PCB 106 & 0.0206 & 0.0167 & 0.0211 & 0.0272 & 0.0173 & 0.0206 & 0.0042 & 20 \\
\hline PCB 107 & 0.153 & 0.176 & 0.241 & 0.148 & 0.198 & 0.183 & 0.038 & 21 \\
\hline PCB 110 & $<\mathrm{LOD}$ & $<\mathrm{LOD}$ & $<$ LOD & $<\mathrm{LOD}$ & $<\mathrm{LOD}$ & $<$ LOD & & \\
\hline PCB 112 & 0.00984 & 0.0105 & 0.0130 & 0.00982 & 0.0157 & 0.0118 & 0.0025 & 22 \\
\hline PCB 114 & 0.0904 & 0.109 & 0.131 & 0.131 & 0.113 & 0.115 & 0.017 & 15 \\
\hline PCB 118 & 3.01 & 3.25 & 4.52 & 3.80 & 4.09 & 3.74 & 0.62 & 16 \\
\hline РCB 119 & 0.0643 & 0.0598 & 0.105 & 0.0613 & 0.106 & 0.0792 & 0.024 & 30 \\
\hline PCB 127 & $<\mathrm{LOQ}$ & $<\mathrm{LOQ}$ & $<$ LOQ & $<$ LOQ & $<\mathrm{LOQ}$ & $<$ LOQ & & \\
\hline PCB 128 & 0.460 & 0.419 & 0.658 & 0.423 & 0.702 & 0.532 & 0.14 & 26 \\
\hline PCB 130 & 0.144 & 0.156 & 0.228 & 0.129 & 0.249 & 0.181 & 0.054 & 30 \\
\hline PCB 137 & 0.153 & 0.121 & 0.228 & 0.133 & 0.256 & 0.178 & 0.060 & 34 \\
\hline PCB 138 & 3.46 & 3.27 & 4.80 & 3.39 & 4.93 & 3.97 & 0.82 & 21 \\
\hline PCB 146 & 1.21 & 1.39 & 1.78 & 1.58 & 1.69 & 1.53 & 0.23 & 15 \\
\hline РCB 149 & 0.247 & 0.267 & 0.316 & 0.238 & 0.298 & 0.273 & 0.033 & 12 \\
\hline
\end{tabular}


Appendix 37 (Continued).

\begin{tabular}{|c|c|c|c|c|c|c|c|c|}
\hline Compound & 1443 & 1446 & 1448 & 1449 & 1452 & Mean & SD & RSD \\
\hline PCB 151 & $<\mathrm{LOQ}$ & 0.0142 & 0.0204 & $<\mathrm{LOQ}$ & 0.0225 & 0.0190 & 0.0043 & 22 \\
\hline PCB $153+132$ & 7.68 & 7.43 & 11.2 & 7.74 & 11.0 & 9.01 & 1.9 & 21 \\
\hline PCB 154 & 0.0842 & 0.0700 & 0.0930 & 0.0682 & 0.113 & 0.0856 & 0.018 & 21 \\
\hline PCB 156 & 0.246 & 0.274 & 0.301 & 0.343 & 0.336 & 0.300 & 0.041 & 14 \\
\hline PCB 157 & 0.0805 & 0.0883 & 0.0939 & 0.105 & 0.100 & 0.0936 & 0.0097 & 10 \\
\hline PCB 158 & 0.135 & 0.181 & 0.326 & 0.165 & 0.176 & 0.197 & 0.075 & 38 \\
\hline PCB 159 & $<\mathrm{LOQ}$ & $<\mathrm{LOQ}$ & $<$ LOQ & $<$ LOQ & $<$ LOQ & $<\mathbf{L O Q}$ & & \\
\hline PCB 163 & 1.02 & 1.19 & 1.51 & 1.13 & 1.48 & 1.27 & 0.22 & 17 \\
\hline PCB 165 & $<$ LOQ & 0.0369 & 0.0341 & 0.0372 & $<$ LOQ & 0.0361 & 0.0017 & 4.6 \\
\hline PCB 166 & 0.0293 & 0.0280 & 0.0311 & 0.0338 & 0.0296 & 0.0304 & 0.0022 & 7.3 \\
\hline PCB 167 & 0.206 & 0.210 & 0.262 & 0.258 & 0.244 & 0.236 & 0.026 & 11 \\
\hline PCB 170 & 0.669 & 0.674 & 0.810 & 0.713 & 0.895 & 0.752 & 0.098 & 13 \\
\hline PCB 172 & 0.155 & 0.213 & 0.209 & 0.234 & 0.202 & 0.203 & 0.029 & 14 \\
\hline PCB 174 & 0.0698 & 0.0630 & 0.0714 & 0.0696 & 0.0667 & 0.0681 & 0.0033 & 4.9 \\
\hline PCB 175 & 0.0528 & 0.0580 & 0.0703 & 0.0645 & 0.0709 & 0.0633 & 0.0078 & 12 \\
\hline PCB 176 & 0.0320 & 0.0305 & 0.0333 & 0.0326 & 0.0312 & 0.0319 & 0.0011 & 3.5 \\
\hline PCB 177 & 0.199 & 0.177 & 0.275 & 0.140 & 0.305 & 0.219 & 0.069 & 32 \\
\hline PCB 178 & 0.295 & 0.281 & 0.445 & 0.242 & 0.317 & 0.316 & 0.077 & 24 \\
\hline PCB $180+193$ & 1.63 & 1.52 & 2.10 & 1.53 & 2.32 & 1.82 & 0.37 & 20 \\
\hline PCB 183 & 0.473 & 0.530 & 0.606 & 0.582 & 0.603 & 0.559 & 0.057 & 10 \\
\hline PCB 185 & 0.0164 & 0.0152 & 0.0173 & $<\mathrm{LOQ}$ & 0.0186 & 0.0169 & 0.0015 & 8.6 \\
\hline PCB 187 & 1.51 & 1.73 & 2.44 & 1.71 & 2.21 & 1.92 & 0.39 & 20 \\
\hline PCB 188 & 0.0261 & 0.0269 & 0.0278 & 0.0355 & 0.0271 & 0.0287 & 0.0039 & 13 \\
\hline PCB 189 & 0.0313 & 0.0314 & 0.0405 & 0.0520 & 0.0491 & 0.0409 & 0.0097 & 24 \\
\hline РCB 191 & $<\mathrm{LOQ}$ & $<\mathrm{LOQ}$ & $<\mathrm{LOQ}$ & $<\mathrm{LOQ}$ & $<$ LOQ & $<\mathbf{L O Q}$ & & \\
\hline РCB 194 & 0.245 & 0.257 & 0.266 & 0.262 & 0.295 & 0.265 & 0.019 & 7.0 \\
\hline PCB 195 & 0.0949 & 0.0811 & 0.0980 & 0.106 & 0.109 & 0.0979 & 0.011 & 11 \\
\hline РCB 196 & 0.430 & 0.415 & 0.468 & 0.525 & 0.528 & 0.473 & 0.052 & 11 \\
\hline РCB 197 & 0.0378 & 0.0376 & 0.0487 & 0.0349 & 0.0453 & 0.0409 & 0.0059 & 14 \\
\hline РCB 199 & 1.18 & 1.49 & 1.45 & 1.77 & 1.61 & 1.50 & 0.22 & 14 \\
\hline РCB 200 & $<\mathrm{LOQ}$ & $<\mathrm{LOQ}$ & $<\mathrm{LOQ}$ & $<\mathrm{LOQ}$ & $<\mathrm{LOQ}$ & $<\mathrm{LOQ}$ & & \\
\hline PCB 201 & 0.489 & 0.588 & 0.820 & 0.709 & 0.608 & 0.643 & 0.13 & 20 \\
\hline PCB 202 & $<\mathrm{LOQ}$ & $<\mathrm{LOQ}$ & $<$ LOQ & $<$ LOQ & $<$ LOQ & $<$ LOQ & & \\
\hline PCB 205 & $<\mathrm{LOQ}$ & $<\mathrm{LOQ}$ & $<\mathrm{LOQ}$ & $<\mathrm{LOQ}$ & $<$ LOQ & $<$ LOQ & & \\
\hline РCB 206 & $<\mathrm{LOQ}$ & $<\mathrm{LOQ}$ & $<\mathrm{LOQ}$ & $<\mathrm{LOQ}$ & $<$ LOQ & $<\mathrm{LOQ}$ & & \\
\hline РCB 207 & 0.0553 & 0.0601 & 0.0669 & 0.0640 & 0.0639 & 0.0620 & 0.0045 & 7.2 \\
\hline РCB 208 & 0.0941 & 0.102 & 0.113 & 0.120 & 0.105 & 0.107 & 0.0099 & 9.2 \\
\hline РСB 209 & 0.0733 & 0.0756 & 0.115 & 0.118 & 0.0830 & 0.0930 & 0.022 & 24 \\
\hline
\end{tabular}


Appendix 38. Brominated diphenyl ether (BDE) and polychlorinated biphenyl (PCB) mass fractions (ng g ${ }^{-1}$ wet mass) in common murre eggs collected at St. Paul Island, Alaska in 2009 (compounds shown in red and blue were above and below reference value ranges, respectively).

\begin{tabular}{|c|c|c|c|c|c|c|c|c|}
\hline Compound & 1479 & 1480 & 1482 & 1485 & 1486 & Mean & SD & RSD \\
\hline BDE47 & 0.313 & 0.0809 & 0.101 & 0.358 & 0.184 & 0.207 & 0.12 & 60 \\
\hline BDE99 & 0.0847 & $<\mathrm{LOQ}$ & $<$ LOQ & 0.0722 & $<$ LOQ & 0.0785 & 0.0088 & 11 \\
\hline BDE100 & 0.152 & 0.106 & $<\mathrm{LOD}$ & 0.162 & 0.0977 & 0.129 & 0.032 & 25 \\
\hline PCB 8 & $<\mathrm{LOD}$ & $<\mathrm{LOD}$ & $<\mathrm{LOD}$ & $<$ LOD & $<\mathrm{LOD}$ & $<$ LOD & & \\
\hline PCB 18 & $<\mathrm{LOD}$ & $<\mathrm{LOD}$ & $<\mathrm{LOD}$ & $<$ LOD & $<\mathrm{LOD}$ & $<$ LOD & & \\
\hline PCB28+31 & 1.85 & 2.17 & 1.41 & 2.38 & 1.41 & 1.84 & 0.44 & 24 \\
\hline PCB 29 & $<$ LOD & $<\mathrm{LOD}$ & $<\mathrm{LOD}$ & $<\mathrm{LOD}$ & $<$ LOD & $<$ LOD & & \\
\hline PCB 44 & 0.0698 & $<\mathrm{LOQ}$ & 0.0563 & 0.0850 & $<$ LOQ & 0.0704 & 0.014 & 20 \\
\hline PCB 45 & $<$ LOQ & $<$ LOQ & $<\mathrm{LOQ}$ & $<$ LOQ & $<$ LOQ & $<\mathbf{L O Q}$ & & \\
\hline PCB 49 & 0.0405 & $<$ LOQ & 0.0306 & 0.0802 & 0.0362 & 0.0469 & 0.023 & 48 \\
\hline PCB 52 & 0.131 & 0.0936 & 0.106 & 0.222 & 0.112 & 0.133 & 0.052 & 39 \\
\hline PCB 56 & 0.234 & 0.163 & 0.158 & 0.197 & 0.173 & 0.185 & 0.031 & 17 \\
\hline PCB 63 & 0.124 & 0.139 & 0.0982 & 0.156 & 0.117 & 0.127 & 0.022 & 17 \\
\hline PCB 66 & 1.55 & 1.70 & 1.01 & 1.65 & 1.26 & 1.43 & 0.29 & 21 \\
\hline PCB 70 & 0.0551 & $<$ LOQ & 0.0492 & 0.103 & 0.0495 & 0.0641 & 0.026 & 40 \\
\hline PCB 74 & 1.19 & 1.20 & 0.670 & 1.26 & 0.908 & 1.05 & 0.25 & 24 \\
\hline PCB 79 & $<$ LOQ & $<\mathrm{LOQ}$ & $<\mathrm{LOQ}$ & $<$ LOQ & $<\mathrm{LOQ}$ & $<\mathrm{LOQ}$ & & \\
\hline PCB 82 & 0.0337 & 0.0367 & 0.0319 & 0.0314 & 0.0337 & 0.0335 & 0.0021 & 6.2 \\
\hline PCB 87 & 0.0679 & 0.0343 & 0.0270 & 0.0972 & 0.0173 & 0.0488 & 0.033 & 68 \\
\hline PCB 92 & 0.0910 & $<\mathrm{LOQ}$ & 0.0826 & 0.116 & $<\mathrm{LOQ}$ & 0.0964 & 0.017 & 18 \\
\hline PCB 95+121 & $<\mathrm{LOD}$ & $<\mathrm{LOD}$ & $<\mathrm{LOD}$ & 0.0332 & 0.0195 & 0.0263 & 0.0097 & 37 \\
\hline РCB 99 & 3.38 & 1.55 & 0.632 & 4.10 & 2.27 & 2.39 & 1.4 & 58 \\
\hline PCB 101 & 0.166 & $<\mathrm{LOQ}$ & 0.145 & 0.298 & 0.146 & 0.189 & 0.074 & 39 \\
\hline PCB 105 & 1.35 & 1.49 & 0.839 & 1.25 & 1.01 & 1.19 & 0.26 & 22 \\
\hline PCB 106 & 0.0178 & 0.0155 & 0.0154 & 0.0167 & 0.0153 & 0.0161 & 0.0011 & 6.6 \\
\hline PCB 107 & 0.227 & 0.274 & 0.183 & 0.236 & 0.231 & 0.230 & 0.032 & 14 \\
\hline PCB 110 & $<\mathrm{LOD}$ & $<\mathrm{LOD}$ & $<\mathrm{LOD}$ & $<\mathrm{LOD}$ & $<\mathrm{LOD}$ & $<$ LOD & & \\
\hline PCB 112 & 0.00848 & $<$ LOQ & $<\mathrm{LOQ}$ & 0.00933 & 0.00671 & 0.00818 & 0.0013 & 16 \\
\hline PCB 114 & 0.143 & 0.182 & 0.115 & 0.138 & 0.114 & 0.138 & 0.028 & 20 \\
\hline PCB 118 & 4.77 & 4.57 & 2.65 & 4.33 & 3.31 & 3.92 & 0.91 & 23 \\
\hline PCB 119 & 0.0769 & 0.0208 & 0.0180 & 0.105 & 0.0436 & 0.0529 & 0.038 & 71 \\
\hline PCB 127 & $<$ LOQ & $<\mathrm{LOQ}$ & $<\mathrm{LOQ}$ & $<\mathrm{LOQ}$ & $<\mathrm{LOQ}$ & $<\mathbf{L O Q}$ & & \\
\hline PCB 128 & 0.521 & 0.227 & 0.155 & 0.581 & 0.308 & 0.359 & 0.19 & 52 \\
\hline PCB 130 & 0.203 & 0.122 & 0.0830 & 0.239 & 0.104 & 0.150 & 0.067 & 45 \\
\hline PCB 137 & 0.178 & 0.0486 & 0.0457 & 0.188 & 0.0986 & 0.112 & 0.068 & 61 \\
\hline PCB 138 & 4.05 & 1.79 & 1.09 & 4.31 & 2.45 & 2.74 & 1.4 & 51 \\
\hline PCB 146 & 1.70 & 1.59 & 0.960 & 1.73 & 1.18 & 1.43 & 0.34 & 24 \\
\hline PCB 149 & 0.256 & 0.191 & 0.186 & 0.311 & 0.207 & 0.230 & 0.053 & 23 \\
\hline
\end{tabular}


Appendix 38 (Continued).

\begin{tabular}{|c|c|c|c|c|c|c|c|c|}
\hline Compound & 1479 & 1480 & 1482 & 1485 & 1486 & Mean & SD & RSD \\
\hline PCB 151 & $<\mathrm{LOQ}$ & $<\mathrm{LOQ}$ & $<\mathrm{LOQ}$ & $<\mathrm{LOQ}$ & $<\mathrm{LOQ}$ & $<\mathrm{LOQ}$ & & \\
\hline PCB $153+132$ & 8.79 & 4.80 & 2.76 & 9.53 & 5.38 & 6.25 & 2.8 & 45 \\
\hline PCB 154 & 0.0774 & $<\mathrm{LOQ}$ & $<\mathrm{LOQ}$ & 0.0878 & 0.0600 & 0.0751 & 0.014 & 19 \\
\hline PCB 156 & 0.348 & 0.434 & 0.267 & 0.263 & 0.266 & 0.316 & 0.075 & 24 \\
\hline PCB 157 & 0.0974 & 0.100 & 0.0723 & 0.0910 & 0.0752 & 0.0873 & 0.013 & 15 \\
\hline PCB 158 & 0.225 & 0.129 & 0.0693 & 0.176 & 0.120 & 0.144 & 0.059 & 41 \\
\hline РCB 159 & $<\mathrm{LOQ}$ & 0.00400 & $<\mathrm{LOQ}$ & $<\mathrm{LOQ}$ & $<\mathrm{LOQ}$ & $<\mathrm{LOQ}$ & & \\
\hline PCB 163 & 1.36 & 1.31 & 0.725 & 1.45 & 0.914 & 1.15 & 0.32 & 27 \\
\hline PCB 165 & 0.0325 & $<\mathrm{LOQ}$ & $<\mathrm{LOQ}$ & $<\mathrm{LOQ}$ & $<\mathrm{LOQ}$ & $<\mathrm{LOQ}$ & & \\
\hline PCB 166 & 0.0289 & 0.0454 & 0.0278 & 0.0439 & 0.0299 & 0.0352 & 0.0087 & 25 \\
\hline PCB 167 & 0.284 & 0.285 & 0.171 & 0.266 & 0.193 & 0.240 & 0.054 & 22 \\
\hline PCB 170 & 0.589 & 0.706 & 0.453 & 0.673 & 0.471 & 0.578 & 0.11 & 20 \\
\hline PCB 172 & 0.228 & 0.292 & 0.200 & 0.196 & 0.169 & 0.217 & 0.047 & 22 \\
\hline PCB 174 & 0.0953 & 0.0818 & 0.0736 & 0.0752 & 0.0782 & 0.0808 & 0.0087 & 11 \\
\hline PCB 175 & 0.0525 & 0.0680 & 0.0565 & 0.0811 & 0.0442 & 0.0605 & 0.014 & 24 \\
\hline PCB 176 & 0.0347 & $<\mathrm{LOQ}$ & 0.0318 & 0.0368 & $<\mathrm{LOQ}$ & 0.0344 & 0.0025 & 7.4 \\
\hline PCB 177 & 0.212 & 0.116 & 0.111 & 0.269 & 0.133 & 0.168 & 0.069 & 41 \\
\hline PCB 178 & 0.279 & 0.323 & 0.251 & 0.393 & 0.197 & 0.289 & 0.074 & 26 \\
\hline PCB 180+193 & 1.90 & 1.11 & 0.719 & 1.75 & 1.13 & 1.32 & 0.49 & 37 \\
\hline РCB 183 & 0.462 & 0.545 & 0.360 & 0.518 & 0.360 & 0.449 & 0.086 & 19 \\
\hline PCB 185 & $<\mathrm{LOQ}$ & $<\mathrm{LOQ}$ & 0.0199 & 0.0147 & $<\mathrm{LOQ}$ & 0.0173 & 0.0037 & 21 \\
\hline PCB 187 & 1.88 & 1.64 & 0.680 & 2.32 & 1.20 & 1.54 & 0.63 & 41 \\
\hline PCB 188 & 0.0277 & 0.0269 & 0.0210 & 0.0364 & 0.0247 & 0.0274 & 0.0057 & 21 \\
\hline PCB 189 & $<$ LOQ & $<\mathrm{LOQ}$ & $<\mathrm{LOQ}$ & $<\mathrm{LOQ}$ & $<\mathrm{LOQ}$ & $<\mathrm{LOQ}$ & & \\
\hline РCB 191 & $<\mathrm{LOQ}$ & $<\mathrm{LOQ}$ & $<\mathrm{LOQ}$ & $<\mathrm{LOQ}$ & $<\mathrm{LOQ}$ & $<\mathrm{LOQ}$ & & \\
\hline РCB 194 & 0.250 & 0.296 & 0.273 & 0.206 & 0.170 & 0.239 & 0.051 & 21 \\
\hline PCB 195 & 0.0945 & 0.103 & 0.0712 & 0.103 & 0.0488 & 0.0840 & 0.024 & 28 \\
\hline РCB 196 & 0.415 & 0.440 & 0.309 & 0.456 & 0.336 & 0.391 & 0.065 & 17 \\
\hline PCB 197 & 0.0360 & 0.0469 & 0.0251 & 0.0411 & 0.0309 & 0.0360 & 0.0085 & 24 \\
\hline РСВ 199 & 1.44 & 1.90 & 1.31 & 1.68 & 1.27 & 1.52 & 0.26 & 17 \\
\hline PCB 200 & $<$ LOQ & $<\mathrm{LOQ}$ & $<\mathrm{LOQ}$ & $<$ LOQ & $<\mathrm{LOQ}$ & $<\mathrm{LOQ}$ & & \\
\hline PCB 201 & 0.500 & 0.534 & 0.432 & 0.825 & 0.380 & 0.534 & 0.17 & 32 \\
\hline PCB 202 & $<\mathrm{LOQ}$ & $<\mathrm{LOQ}$ & $<\mathrm{LOQ}$ & 0.132 & $<\mathrm{LOQ}$ & $<\mathrm{LOQ}$ & & \\
\hline PCB 205 & 0.0298 & 0.0456 & 0.0353 & 0.0292 & $<\mathrm{LOQ}$ & 0.0350 & 0.0076 & 22 \\
\hline PCB 206 & $<\mathrm{LOQ}$ & $<\mathrm{LOQ}$ & $<\mathrm{LOQ}$ & $<\mathrm{LOQ}$ & $<\mathrm{LOQ}$ & $<\mathrm{LOQ}$ & & \\
\hline РCB 207 & 0.0615 & 0.0624 & 0.0499 & 0.0643 & 0.0468 & 0.0570 & 0.0080 & 14 \\
\hline РCB 208 & 0.0854 & 0.102 & 0.0995 & 0.107 & $<\mathrm{LOQ}$ & 0.0987 & 0.0094 & 9.6 \\
\hline PCB 209 & 0.0805 & 0.132 & 0.0955 & 0.0936 & $<\mathrm{LOQ}$ & 0.101 & 0.022 & 22 \\
\hline
\end{tabular}


Appendix 39. Brominated diphenyl ether (BDE) and polychlorinated biphenyl (PCB) mass fractions (ng $\mathrm{g}^{-1}$ wet mass) in thick-billed murre eggs collected at St. George Island, Alaska in 2008 (compounds shown in red and blue were above and below reference value ranges, respectively).

\begin{tabular}{|c|c|c|c|c|c|c|c|c|}
\hline Compound & 1321 & 1331 & 1333 & 1334 & 1335 & Mean & SD & RSD \\
\hline BDE47 & 0.325 & 0.618 & 0.206 & 0.193 & 0.595 & 0.388 & 0.21 & 53 \\
\hline BDE99 & $<\mathrm{LOQ}$ & $<\mathrm{LOQ}$ & $<\mathrm{LOQ}$ & $<\mathrm{LOQ}$ & 0.932 & $<\mathrm{LOQ}$ & & \\
\hline BDE100 & 0.510 & 0.500 & 0.467 & 0.478 & 0.573 & 0.506 & 0.041 & 8.1 \\
\hline PCB 8 & $<\mathrm{LOD}$ & $<\mathrm{LOD}$ & $<\mathrm{LOD}$ & $<\mathrm{LOD}$ & $<\mathrm{LOD}$ & $<$ LOD & & \\
\hline РCB 18 & $<\mathrm{LOD}$ & $<\mathrm{LOD}$ & $<\mathrm{LOD}$ & $<\mathrm{LOD}$ & $<\mathrm{LOD}$ & $<$ LOD & & \\
\hline PCB $28+31$ & 2.18 & 1.88 & 2.66 & 1.78 & 2.28 & 2.15 & 0.35 & 16 \\
\hline PCB 29 & $<$ LOQ & $<\mathrm{LOQ}$ & $<$ LOQ & $<$ LOQ & $<\mathrm{LOQ}$ & $<$ LOQ & & \\
\hline PCB 44 & 0.0873 & 0.126 & 0.0491 & 0.0397 & 0.0665 & 0.0737 & 0.035 & 47 \\
\hline PCB 45 & $<$ LOQ & $<$ LOQ & $<$ LOQ & $<\mathrm{LOQ}$ & $<\mathrm{LOQ}$ & $<$ LOQ & & \\
\hline РCB 49 & 0.0515 & 0.129 & $<\mathrm{LOQ}$ & 0.0514 & 0.0970 & 0.0821 & 0.038 & 46 \\
\hline PCB 52 & 0.0561 & 0.288 & 0.0436 & 0.0514 & 0.176 & 0.123 & 0.11 & 87 \\
\hline PCB 56 & $<$ LOQ & $<$ LOQ & $<$ LOQ & $<\mathrm{LOQ}$ & $<\mathrm{LOQ}$ & $<$ LOQ & & \\
\hline PCB 63 & 0.276 & $<\mathrm{LOQ}$ & 0.200 & $<$ LOQ & 0.192 & 0.223 & 0.047 & 21 \\
\hline PCB 66 & 2.38 & 3.02 & 3.17 & 2.43 & 3.19 & 2.84 & 0.40 & 14 \\
\hline PCB 70 & $<\mathrm{LOD}$ & 0.125 & $<\mathrm{LOD}$ & $<\mathrm{LOD}$ & 0.0708 & 0.0981 & 0.039 & 39 \\
\hline PCB 74 & 2.19 & 2.53 & 2.80 & 2.23 & 2.79 & 2.51 & 0.29 & 12 \\
\hline РСB 79 & $<$ LOQ & $<$ LOQ & $<$ LOQ & $<\mathrm{LOQ}$ & $<$ LOQ & $<$ LOQ & & \\
\hline PCB 82 & $<\mathrm{LOD}$ & 0.0173 & $<\mathrm{LOD}$ & 0.00450 & $<\mathrm{LOD}$ & 0.0109 & 0.0091 & 83 \\
\hline PCB 87 & 0.135 & 0.185 & 0.115 & 0.0941 & 0.0966 & 0.125 & 0.037 & 30 \\
\hline PCB 92 & 0.0304 & 0.0953 & 0.0367 & 0.0452 & 0.0729 & 0.0561 & 0.027 & 49 \\
\hline PCB 95+121 & $<\mathrm{LOD}$ & $<\mathrm{LOD}$ & $<\mathrm{LOD}$ & $<\mathrm{LOD}$ & $<\mathrm{LOD}$ & $<$ LOD & & \\
\hline PCB 99 & 1.70 & 6.85 & 4.94 & 3.75 & 7.05 & 4.86 & 2.2 & 46 \\
\hline PCB 101 & 0.145 & 0.143 & 0.164 & $<\mathrm{LOD}$ & $<\mathrm{LOD}$ & 0.151 & 0.012 & 7.7 \\
\hline PCB 105 & 2.98 & 2.66 & 2.62 & 2.30 & 2.54 & 2.62 & 0.24 & 9.3 \\
\hline PCB 106 & $<\mathrm{LOQ}$ & $<$ LOQ & $<$ LOQ & $<$ LOQ & 0.0287 & $<$ LOQ & & \\
\hline PCB 107 & 0.634 & 0.385 & 0.583 & 0.345 & 0.586 & 0.507 & 0.13 & 26 \\
\hline PCB 110 & $<\mathrm{LOD}$ & $<\mathrm{LOD}$ & $<\mathrm{LOD}$ & $<\mathrm{LOD}$ & $<\mathrm{LOD}$ & $<$ LOD & & \\
\hline PCB 112 & $<\mathrm{LOD}$ & $<\mathrm{LOD}$ & $<\mathrm{LOD}$ & $<\mathrm{LOD}$ & $<\mathrm{LOD}$ & $<$ LOD & & \\
\hline PCB 114 & 0.360 & 0.311 & 0.289 & 0.276 & 0.279 & 0.303 & 0.035 & 11 \\
\hline PCB 118 & 6.91 & 9.98 & 9.39 & 8.11 & 10.2 & 8.93 & 1.4 & 16 \\
\hline PCB 119 & 0.139 & 0.153 & 0.103 & 0.0739 & 0.158 & 0.125 & 0.036 & 29 \\
\hline PCB 127 & $<\mathrm{LOD}$ & $<\mathrm{LOD}$ & $<\mathrm{LOD}$ & $<\mathrm{LOD}$ & $<\mathrm{LOD}$ & $<$ LOD & & \\
\hline PCB 128 & 1.20 & 1.16 & 1.11 & 0.991 & 1.17 & 1.13 & 0.083 & 7.4 \\
\hline PCB 130 & 0.580 & 0.480 & 0.495 & 0.447 & 0.497 & 0.500 & 0.049 & 9.9 \\
\hline PCB 137 & 0.133 & 0.490 & 0.245 & 0.223 & 0.450 & 0.308 & 0.15 & 50 \\
\hline PCB 138 & 1.33 & 8.05 & 5.59 & 5.05 & 8.12 & 5.63 & 2.8 & 49 \\
\hline PCB 146 & 2.35 & 3.42 & 2.95 & 2.67 & 3.45 & 2.97 & 0.48 & 16 \\
\hline PCB 149 & 0.378 & 0.459 & 0.344 & 0.284 & 0.417 & 0.376 & 0.067 & 18 \\
\hline
\end{tabular}


Appendix 39 (Continued).

\begin{tabular}{|c|c|c|c|c|c|c|c|c|}
\hline Compound & 1321 & 1331 & 1333 & 1334 & 1335 & Mean & SD & RSD \\
\hline PCB 151 & $<$ LOQ & $<$ LOQ & $<\mathrm{LOQ}$ & 0.0879 & 0.0810 & 0.0844 & 0.0049 & 5.8 \\
\hline РCB $153+132$ & 7.12 & 17.3 & 10.8 & 9.33 & 17.4 & 12.4 & 4.7 & 38 \\
\hline PCB 154 & 0.0705 & 0.108 & 0.0926 & 0.0878 & 0.109 & 0.0936 & 0.016 & 17 \\
\hline PCB 156 & 0.824 & 0.670 & 0.706 & 0.633 & 0.695 & 0.706 & 0.072 & 10 \\
\hline PCB 157 & 0.252 & 0.207 & 0.201 & 0.184 & 0.216 & 0.212 & 0.025 & 12 \\
\hline PCB 158 & 0.305 & 0.297 & 0.288 & 0.237 & 0.365 & 0.299 & 0.046 & 15 \\
\hline PCB 159 & $<\mathrm{LOQ}$ & $<\mathrm{LOQ}$ & $<\mathrm{LOQ}$ & $<\mathrm{LOQ}$ & $<\mathrm{LOQ}$ & $<$ LOQ & & \\
\hline PCB 163 & 3.07 & 2.49 & 2.61 & 2.71 & 2.54 & 2.68 & 0.23 & 8.5 \\
\hline PCB 165 & 0.0328 & 0.0354 & 0.0183 & 0.0291 & 0.0269 & 0.0285 & 0.0066 & 23 \\
\hline PCB 166 & 0.0770 & 0.0760 & 0.0492 & 0.0563 & 0.0595 & 0.0636 & 0.012 & 19 \\
\hline PCB 167 & 0.277 & 0.504 & 0.330 & 0.296 & 0.438 & 0.369 & 0.098 & 27 \\
\hline PCB 170 & 1.39 & 1.26 & 1.24 & 1.07 & 1.29 & 1.25 & 0.11 & 9.1 \\
\hline PCB 172 & 0.472 & 0.426 & 0.423 & 0.415 & 0.377 & 0.422 & 0.034 & 8.0 \\
\hline PCB 174 & 0.0513 & 0.0569 & 0.0445 & 0.0514 & 0.0430 & 0.0494 & 0.0057 & 11 \\
\hline PCB 175 & 0.0974 & 0.105 & 0.0972 & 0.0941 & 0.0667 & 0.0920 & 0.015 & 16 \\
\hline PCB 176 & $<\mathrm{LOQ}$ & 0.0167 & $<\mathrm{LOQ}$ & 0.00721 & $<\mathrm{LOQ}$ & 0.0120 & 0.0067 & 56 \\
\hline PCB 177 & 0.350 & 0.350 & 0.368 & 0.309 & 0.292 & 0.334 & 0.032 & 9.6 \\
\hline РCB 178 & 0.513 & 0.442 & 0.403 & 0.447 & 0.360 & 0.433 & 0.057 & 13 \\
\hline PCB $180+193$ & 1.75 & 3.22 & 2.11 & 1.88 & 3.32 & 2.46 & 0.75 & 31 \\
\hline PCB 183 & 0.839 & 0.747 & 0.575 & 0.520 & 0.633 & 0.663 & 0.13 & 20 \\
\hline PCB 185 & 0.0410 & 0.0427 & 0.0198 & 0.0208 & 0.0226 & 0.0294 & 0.011 & 39 \\
\hline PCB 187 & 3.96 & 3.49 & 3.00 & 2.92 & 3.19 & 3.31 & 0.43 & 13 \\
\hline PCB 188 & 0.0326 & 0.0226 & 0.0276 & 0.0190 & 0.0214 & 0.0246 & 0.0054 & 22 \\
\hline PCB 189 & 0.0762 & 0.0721 & 0.0239 & 0.0724 & 0.0656 & 0.0620 & 0.022 & 35 \\
\hline PCB 191 & 0.0279 & 0.0145 & 0.0290 & 0.0330 & 0.0188 & 0.0246 & 0.0077 & 31 \\
\hline PCB 194 & 0.344 & 0.222 & 0.315 & 0.248 & 0.262 & 0.278 & 0.050 & 18 \\
\hline PCB 195 & 0.162 & 0.136 & 0.114 & 0.130 & 0.168 & 0.142 & 0.022 & 16 \\
\hline PCB 196 & 0.700 & 0.651 & 0.716 & 0.613 & 0.766 & 0.689 & 0.059 & 8.6 \\
\hline PCB 197 & 0.0508 & 0.0712 & 0.0568 & 0.0263 & 0.0459 & 0.0502 & 0.016 & 33 \\
\hline PCB 199 & 3.14 & 2.70 & 3.19 & 2.50 & 2.97 & 2.90 & 0.29 & 10 \\
\hline PCB 200 & $<\mathrm{LOD}$ & $<\mathrm{LOD}$ & $<\mathrm{LOD}$ & $<\mathrm{LOD}$ & $<\mathrm{LOD}$ & $<$ LOD & & \\
\hline PCB 201 & 0.968 & 0.818 & 1.08 & 0.742 & 0.796 & 0.880 & 0.14 & 16 \\
\hline PCB 202 & 0.0383 & 0.0472 & 0.0545 & 0.0595 & $<\mathrm{LOQ}$ & 0.0499 & 0.0092 & 18 \\
\hline PCB 205 & 0.0324 & 0.0278 & 0.0197 & 0.0234 & 0.0214 & 0.0249 & 0.0051 & 21 \\
\hline PCB 206 & 0.200 & 0.139 & 0.248 & 0.271 & 0.172 & 0.206 & 0.054 & 26 \\
\hline PCB 207 & 0.0475 & 0.0475 & 0.0598 & 0.0466 & 0.0712 & 0.0545 & 0.011 & 20 \\
\hline PCB 208 & 0.129 & 0.0731 & 0.120 & 0.166 & 0.149 & 0.127 & 0.035 & 28 \\
\hline РCB 209 & 0.0927 & 0.0852 & 0.120 & 0.117 & 0.140 & 0.111 & 0.022 & 20 \\
\hline
\end{tabular}


Appendix 40. Brominated diphenyl ether (BDE) and polychlorinated biphenyl (PCB) mass fractions ( $\mathrm{ng} \mathrm{g}^{-1}$ wet mass) in common murre eggs collected at St. George Island, Alaska in 2009 (compounds shown in red and blue were above and below reference value ranges, respectively).

\begin{tabular}{|c|c|c|c|c|c|c|c|c|}
\hline Compound & 1463 & 1466 & 1469 & 1470 & 1472 & Mean & SD & RSD \\
\hline BDE47 & 0.319 & 0.426 & 0.101 & 0.464 & 0.336 & 0.329 & 0.14 & 43 \\
\hline BDE99 & 0.0955 & 0.116 & $<\mathrm{LOQ}$ & 0.139 & 0.110 & 0.115 & 0.018 & 16 \\
\hline BDE100 & 0.221 & 0.147 & $<$ LOD & 0.299 & 0.212 & 0.220 & 0.062 & 28 \\
\hline PCB 8 & $<\mathrm{LOD}$ & $<\mathrm{LOD}$ & $<\mathrm{LOD}$ & $<\mathrm{LOD}$ & $<\mathrm{LOD}$ & $<$ LOD & & \\
\hline PCB 18 & $<\mathrm{LOD}$ & $<$ LOD & $<\mathrm{LOD}$ & $<\mathrm{LOD}$ & $<\mathrm{LOD}$ & $<$ LOD & & \\
\hline PCB28+31 & 1.86 & 2.42 & 1.93 & 1.85 & 2.12 & 2.03 & 0.24 & 12 \\
\hline РCB 29 & $<\mathrm{LOD}$ & $<$ LOD & $<$ LOD & $<\mathrm{LOD}$ & $<$ LOD & $<$ LOD & & \\
\hline PCB 44 & 0.0553 & 0.0603 & 0.0682 & 0.0776 & 0.0672 & 0.0657 & 0.0085 & 13 \\
\hline PCB 45 & $<$ LOQ & $<\mathrm{LOQ}$ & $<$ LOQ & $<\mathrm{LOQ}$ & $<\mathrm{LOQ}$ & $<\mathbf{L O Q}$ & & \\
\hline РCB 49 & 0.0441 & 0.0535 & 0.0372 & 0.0626 & 0.0885 & 0.0572 & 0.020 & 35 \\
\hline PCB 52 & 0.137 & 0.156 & 0.114 & 0.162 & 0.164 & 0.147 & 0.021 & 14 \\
\hline PCB 56 & 0.140 & 0.159 & 0.146 & 0.150 & 0.147 & 0.148 & 0.0068 & 4.6 \\
\hline PCB 63 & 0.0749 & 0.130 & 0.107 & 0.116 & 0.140 & 0.113 & 0.025 & 22 \\
\hline PCB 66 & 0.878 & 1.66 & 1.52 & 1.69 & 1.54 & 1.46 & 0.33 & 23 \\
\hline PCB 70 & 0.0489 & 0.0588 & 0.0458 & 0.0871 & 0.0751 & 0.0631 & 0.018 & 28 \\
\hline РСB 74 & 0.729 & 1.26 & 1.16 & 1.25 & 1.23 & 1.12 & 0.22 & 20 \\
\hline PCB 79 & 0.0248 & 0.0296 & 0.0303 & 0.0331 & 0.0431 & 0.0322 & 0.0068 & 21 \\
\hline PCB 82 & 0.0292 & 0.0408 & 0.0376 & 0.0444 & 0.0387 & 0.0381 & 0.0056 & 15 \\
\hline РCB 87 & 0.0140 & 0.102 & 0.0574 & 0.0966 & 0.0897 & 0.0719 & 0.037 & 51 \\
\hline РCB 92 & 0.105 & 0.272 & 0.0866 & 0.101 & 0.0959 & 0.132 & 0.079 & 60 \\
\hline РCB 95+121 & 0.0188 & 0.0617 & $<\mathrm{LOD}$ & 0.0384 & 0.0453 & 0.0411 & 0.018 & 43 \\
\hline PCB 99 & 5.67 & 4.02 & 3.10 & 3.60 & 3.30 & 3.94 & 1.0 & 26 \\
\hline PCB 101 & 0.199 & 0.203 & 0.152 & 0.211 & 0.191 & 0.191 & 0.023 & 12 \\
\hline PCB 105 & 1.05 & 1.25 & 1.14 & 1.24 & 1.12 & 1.16 & 0.084 & 7.3 \\
\hline PCB 106 & 0.0229 & 0.0493 & 0.0237 & 0.0274 & 0.0186 & 0.0284 & 0.012 & 43 \\
\hline PCB 107 & 0.193 & 0.258 & 0.241 & 0.187 & 0.251 & 0.226 & 0.033 & 15 \\
\hline PCB 110 & $<\mathrm{LOD}$ & $<\mathrm{LOD}$ & $<\mathrm{LOD}$ & $<$ LOD & $<$ LOD & $<$ LOD & & \\
\hline PCB 112 & 0.00695 & 0.0106 & 0.00818 & 0.0119 & 0.0129 & 0.0101 & 0.0025 & 25 \\
\hline PCB 114 & 0.136 & 0.141 & 0.138 & 0.137 & 0.140 & 0.138 & 0.0023 & 1.7 \\
\hline PCB 118 & 4.00 & 4.51 & 4.14 & 4.30 & 3.89 & 4.17 & 0.24 & 5.9 \\
\hline PCB 119 & 0.103 & 0.103 & 0.0417 & 0.100 & 0.0927 & 0.0881 & 0.026 & 30 \\
\hline PCB 127 & $<$ LOQ & $<\mathrm{LOQ}$ & $<$ LOQ & $<\mathrm{LOQ}$ & $<\mathrm{LOQ}$ & $<\mathbf{L O Q}$ & & \\
\hline PCB 128 & 0.481 & 0.553 & 0.422 & 0.517 & 0.468 & 0.488 & 0.049 & 10 \\
\hline PCB 130 & 0.189 & 0.237 & 0.200 & 0.228 & 0.215 & 0.214 & 0.020 & 9.1 \\
\hline PCB 137 & 0.151 & 0.193 & 0.131 & 0.171 & 0.184 & 0.166 & 0.025 & 15 \\
\hline PCB 138 & 3.59 & 4.13 & 3.51 & 3.96 & 3.61 & 3.76 & 0.27 & 7.2 \\
\hline PCB 146 & 1.53 & 1.69 & 1.53 & 1.69 & 1.52 & 1.59 & 0.090 & 5.6 \\
\hline PCB 149 & 0.239 & 0.262 & 0.227 & 0.280 & 0.262 & 0.254 & 0.021 & 8.3 \\
\hline
\end{tabular}


Appendix 40 (Continued).

\begin{tabular}{|c|c|c|c|c|c|c|c|c|}
\hline Compound & 1463 & 1466 & 1469 & 1470 & 1472 & Mean & SD & RSD \\
\hline PCB 151 & $<$ LOQ & $<$ LOQ & $<\mathrm{LOQ}$ & $<$ LOQ & 0.0170 & $<$ LOQ & & \\
\hline PCB $153+132$ & 7.96 & 9.13 & 7.07 & 8.79 & 7.76 & 8.14 & 0.82 & 10 \\
\hline PCB 154 & 0.0707 & 0.0810 & 0.0660 & 0.0861 & 0.0838 & 0.0775 & 0.0087 & 11 \\
\hline PCB 156 & 0.193 & 0.303 & 0.311 & 0.293 & 0.298 & 0.280 & 0.049 & 18 \\
\hline PCB 157 & 0.0632 & 0.0814 & 0.0813 & 0.0943 & 0.0975 & 0.0835 & 0.014 & 16 \\
\hline PCB 158 & 0.175 & 0.199 & 0.212 & 0.245 & 0.216 & 0.209 & 0.025 & 12 \\
\hline PCB 159 & $<$ LOQ & 0.00628 & 0.00381 & 0.00261 & 0.0273 & 0.0100 & 0.012 & 120 \\
\hline PCB 163 & 1.23 & 1.36 & 1.40 & 1.42 & 1.27 & 1.34 & 0.083 & 6.2 \\
\hline PCB 165 & 0.0333 & 0.0375 & 0.0390 & 0.0325 & 0.0486 & 0.0382 & 0.0064 & 17 \\
\hline PCB 166 & 0.0354 & 0.0394 & 0.0288 & 0.0689 & 0.0473 & 0.0440 & 0.015 & 35 \\
\hline PCB 167 & 0.168 & 0.265 & 0.250 & 0.269 & 0.282 & 0.247 & 0.046 & 18 \\
\hline PCB 170 & 0.381 & 0.741 & 0.590 & 0.699 & 0.578 & 0.598 & 0.14 & 23 \\
\hline PCB 172 & 0.188 & 0.223 & 0.224 & 0.220 & 0.224 & 0.216 & 0.016 & 7.2 \\
\hline PCB 174 & 0.0627 & 0.0798 & 0.0690 & 0.0649 & 0.0949 & 0.0742 & 0.013 & 18 \\
\hline PCB 175 & 0.0578 & 0.0747 & 0.0542 & 0.0653 & 0.0970 & 0.0698 & 0.017 & 25 \\
\hline PCB 176 & $<\mathrm{LOQ}$ & 0.0318 & 0.0328 & 0.0307 & 0.0573 & 0.0381 & 0.013 & 33 \\
\hline PCB 177 & 0.221 & 0.262 & 0.257 & 0.276 & 0.257 & 0.255 & 0.020 & 7.9 \\
\hline PCB 178 & 0.386 & 0.366 & 0.330 & 0.291 & 0.256 & 0.326 & 0.053 & 16 \\
\hline PCB 180+193 & 1.62 & 1.87 & 1.50 & 1.88 & 1.72 & 1.72 & 0.16 & 9.6 \\
\hline PCB 183 & 0.442 & 0.490 & 0.460 & 0.502 & 0.464 & 0.472 & 0.024 & 5.2 \\
\hline PCB 185 & $<$ LOQ & 0.0232 & 0.0146 & 0.0178 & 0.0378 & 0.0234 & 0.010 & 44 \\
\hline PCB 187 & 2.02 & 2.26 & 2.35 & 2.24 & 2.03 & 2.18 & 0.15 & 6.8 \\
\hline PCB 188 & 0.0294 & 0.0359 & 0.0378 & 0.0332 & 0.0482 & 0.0369 & 0.0071 & 19 \\
\hline PCB 189 & $<$ LOQ & 0.0415 & 0.0330 & $<$ LOQ & $<$ LOQ & 0.0372 & 0.0060 & 16 \\
\hline PCB 191 & $<$ LOQ & $<\mathrm{LOQ}$ & $<\mathrm{LOQ}$ & $<\mathrm{LOQ}$ & $<$ LOQ & $<\mathbf{L O Q}$ & & \\
\hline PCB 194 & 0.222 & 0.281 & 0.271 & 0.317 & 0.247 & 0.268 & 0.036 & 13 \\
\hline PCB 195 & 0.0560 & 0.100 & 0.0797 & 0.0539 & 0.0840 & 0.0748 & 0.020 & 26 \\
\hline PCB 196 & 0.444 & 0.448 & 0.455 & 0.459 & 0.439 & 0.449 & 0.0079 & 1.7 \\
\hline PCB 197 & 0.0466 & 0.0309 & 0.0453 & 0.0269 & 0.0741 & 0.0448 & 0.019 & 41 \\
\hline РCB 199 & 1.72 & 1.66 & 1.85 & 1.88 & 1.65 & 1.75 & 0.11 & 6.1 \\
\hline PCB 200 & $<$ LOQ & $<\mathrm{LOQ}$ & $<\mathrm{LOQ}$ & $<$ LOQ & $<$ LOQ & $<\mathbf{L O Q}$ & & \\
\hline PCB 201 & 0.667 & 0.779 & 0.604 & 0.856 & 0.749 & 0.731 & 0.098 & 13 \\
\hline PCB 202 & $<$ LOQ & $<\mathrm{LOQ}$ & $<\mathrm{LOQ}$ & $<$ LOQ & $<$ LOQ & $<\mathrm{LOQ}$ & & \\
\hline PCB 205 & $<\mathrm{LOQ}$ & 0.0640 & 0.0398 & 0.0346 & 0.0599 & 0.0496 & 0.015 & 29 \\
\hline PCB 206 & $<\mathrm{LOQ}$ & $<\mathrm{LOQ}$ & $<\mathrm{LOQ}$ & $<\mathrm{LOQ}$ & $<\mathrm{LOQ}$ & $<\mathbf{L O Q}$ & & \\
\hline PCB 207 & 0.0683 & 0.0778 & 0.0537 & 0.0752 & 0.0773 & 0.0704 & 0.010 & 14 \\
\hline PCB 208 & 0.0999 & 0.137 & 0.124 & 0.109 & 0.126 & 0.119 & 0.015 & 12 \\
\hline PCB 209 & 0.0976 & 0.127 & 0.117 & 0.108 & 0.119 & 0.114 & 0.011 & 10 \\
\hline
\end{tabular}


Appendix 41. Brominated diphenyl ether (BDE) and polychlorinated biphenyl (PCB) mass Fractions (ng g ${ }^{-1}$ wet mass) in common murre eggs collected at St. Lazaria Island, Alaska in 2008 (compounds shown in red and blue were above and below reference value ranges, respectively).

\begin{tabular}{|c|c|c|c|c|c|c|c|c|}
\hline Compound & 1234 & 1235 & 1236 & 1238 & 1240 & Mean & SD & RSD \\
\hline BDE47 & 4.50 & 3.28 & 7.92 & 49.0 & 9.19 & 14.8 & 19 & 130 \\
\hline BDE99 & 1.52 & 1.02 & 2.90 & 6.39 & 4.34 & 3.23 & 2.2 & 68 \\
\hline BDE100 & 1.77 & 0.972 & 2.26 & 14.2 & 3.38 & 4.51 & 5.5 & 120 \\
\hline PCB 8 & 0.0315 & 0.0245 & $<\mathrm{LOD}$ & 0.0116 & $<\mathrm{LOD}$ & 0.0225 & 0.010 & 45 \\
\hline PCB 18 & $<\mathrm{LOD}$ & $<\mathrm{LOD}$ & $<\mathrm{LOD}$ & $<\mathrm{LOD}$ & $<\mathrm{LOD}$ & $<$ LOD & & \\
\hline PCB $28+31$ & 1.66 & 1.56 & 2.41 & 3.56 & 2.92 & 2.42 & 0.85 & 35 \\
\hline PCB 29 & $<\mathrm{LOQ}$ & $<\mathrm{LOQ}$ & $<\mathrm{LOQ}$ & $<\mathrm{LOQ}$ & $<\mathrm{LOQ}$ & $<\mathrm{LOQ}$ & & \\
\hline РCB 44 & 0.0482 & 0.0613 & 0.0885 & 0.0733 & 0.0805 & 0.0703 & 0.016 & 23 \\
\hline PCB 45 & $<\mathrm{LOQ}$ & $<\mathrm{LOQ}$ & $<\mathrm{LOQ}$ & $<\mathrm{LOQ}$ & $<\mathrm{LOQ}$ & $<$ LOQ & & \\
\hline РCB 49 & 0.0544 & 0.0664 & 0.0966 & 0.120 & 0.441 & 0.156 & 0.16 & 100 \\
\hline PCB 52 & $<\mathrm{LOD}$ & 0.0987 & 0.196 & 0.229 & 0.543 & 0.267 & 0.19 & 72 \\
\hline PCB 56 & $<$ LOQ & $<\mathrm{LOQ}$ & $<\mathrm{LOQ}$ & $<\mathrm{LOQ}$ & $<\mathrm{LOQ}$ & $<$ LOQ & & \\
\hline PCB 63 & 0.191 & $<\mathrm{LOQ}$ & $<$ LOQ & 0.475 & 0.202 & 0.289 & 0.16 & 56 \\
\hline PCB 66 & 1.56 & 1.90 & 2.61 & 5.64 & 2.83 & 2.91 & 1.6 & 55 \\
\hline PCB 70 & $<\mathrm{LOD}$ & 0.0305 & 0.0847 & 0.103 & 0.453 & 0.168 & 0.19 & 120 \\
\hline PCB 74 & 1.37 & 1.36 & 1.97 & 4.72 & 2.33 & 2.35 & 1.4 & 59 \\
\hline РCB 79 & $<$ LOQ & $<\mathrm{LOQ}$ & $<$ LOQ & $<\mathrm{LOQ}$ & $<\mathrm{LOQ}$ & $<\mathrm{LOQ}$ & & \\
\hline PCB 82 & $<\mathrm{LOD}$ & $<\mathrm{LOD}$ & $<\mathrm{LOD}$ & 0.00448 & 0.0288 & 0.0166 & 0.017 & 100 \\
\hline PCB 87 & 0.105 & $<\mathrm{LOD}$ & 0.134 & 0.643 & 0.598 & 0.370 & 0.29 & 78 \\
\hline РCB 92 & 0.0298 & 0.0631 & 0.109 & 0.0861 & 0.150 & 0.0876 & 0.046 & 52 \\
\hline PCB 95+121 & $<\mathrm{LOD}$ & $<\mathrm{LOD}$ & $<\mathrm{LOD}$ & $<\mathrm{LOD}$ & 0.188 & $<$ LOD & & \\
\hline РCB 99 & 1.48 & 3.35 & 6.47 & 21.4 & 8.72 & 8.28 & 7.8 & 95 \\
\hline PCB 101 & $<\mathrm{LOD}$ & $<\mathrm{LOD}$ & 0.166 & 0.184 & 4.01 & 1.45 & 2.2 & 150 \\
\hline PCB 105 & 2.14 & 1.63 & 2.89 & 10.9 & 2.80 & 4.08 & 3.9 & 95 \\
\hline PCB 106 & $<\mathrm{LOQ}$ & $<\mathrm{LOQ}$ & $<\mathrm{LOQ}$ & 0.0272 & $<\mathrm{LOQ}$ & $<$ LOQ & & \\
\hline PCB 107 & 0.552 & 0.285 & 0.509 & 2.14 & 0.751 & 0.847 & 0.74 & 87 \\
\hline PCB 110 & $<\mathrm{LOD}$ & $<\mathrm{LOD}$ & $<\mathrm{LOD}$ & $<\mathrm{LOD}$ & 0.624 & $<$ LOD & & \\
\hline PCB 112 & $<\mathrm{LOD}$ & $<\mathrm{LOD}$ & $<\mathrm{LOD}$ & $<\mathrm{LOD}$ & $<\mathrm{LOD}$ & $<$ LOD & & \\
\hline PCB 114 & 0.233 & 0.161 & 0.262 & 0.856 & 0.267 & 0.356 & 0.28 & 79 \\
\hline PCB 118 & 5.12 & 5.29 & 9.74 & 30.8 & 11.2 & 12.4 & 11 & 85 \\
\hline PCB 119 & 0.120 & 0.0739 & 0.161 & 0.546 & 0.288 & 0.238 & 0.19 & 80 \\
\hline PCB 127 & $<\mathrm{LOD}$ & $<\mathrm{LOD}$ & $<\mathrm{LOD}$ & $<\mathrm{LOD}$ & $<\mathrm{LOD}$ & $<$ LOD & & \\
\hline PCB 128 & 1.31 & 0.612 & 1.29 & 6.25 & 2.25 & 2.34 & 2.3 & 97 \\
\hline PCB 130 & 0.641 & 0.296 & 0.594 & 2.63 & 1.21 & 1.07 & 0.93 & 87 \\
\hline PCB 137 & 0.103 & 0.150 & 0.308 & 1.43 & 0.751 & 0.549 & 0.56 & 100 \\
\hline PCB 138 & 1.89 & 4.46 & 9.85 & 41.4 & 15.7 & 14.7 & 16 & 110 \\
\hline PCB 146 & 3.00 & 2.62 & 5.35 & 16.5 & 5.69 & 6.62 & 5.7 & 85 \\
\hline PCB 149 & 0.502 & 0.318 & 0.666 & 0.927 & 2.64 & 1.01 & 0.94 & 93 \\
\hline
\end{tabular}


Appendix 41 (Continued).

\begin{tabular}{|c|c|c|c|c|c|c|c|c|}
\hline Compound & 1234 & 1235 & 1236 & 1238 & 1240 & Mean & SD & RSD \\
\hline PCB 151 & 0.0755 & $<$ LOQ & 0.142 & 0.202 & 0.381 & 0.200 & 0.13 & 66 \\
\hline PCB $153+132$ & 9.12 & 10.6 & 23.0 & 85.9 & 34.4 & 32.6 & 32 & 97 \\
\hline PCB 154 & 0.116 & 0.0787 & 0.140 & 0.294 & 0.509 & 0.227 & 0.18 & 78 \\
\hline PCB 156 & 0.979 & 0.645 & 1.33 & 3.13 & 1.06 & 1.43 & 0.98 & 69 \\
\hline PCB 157 & 0.238 & 0.154 & 0.290 & 0.845 & 0.296 & 0.365 & 0.27 & 75 \\
\hline PCB 158 & 0.585 & 0.155 & 0.564 & 2.29 & 1.17 & 0.954 & 0.83 & 87 \\
\hline PCB 159 & $<\mathrm{LOQ}$ & $<\mathrm{LOQ}$ & $<\mathrm{LOQ}$ & $<\mathrm{LOQ}$ & $<\mathrm{LOQ}$ & $<$ LOQ & & \\
\hline PCB 163 & 4.49 & 2.26 & 4.42 & 15.1 & 5.51 & 6.35 & 5.0 & 79 \\
\hline PCB 165 & 0.0430 & 0.0294 & 0.0356 & 0.150 & 0.0641 & 0.0645 & 0.050 & 77 \\
\hline PCB 166 & 0.0474 & 0.0327 & 0.0512 & 0.164 & 0.0807 & 0.0752 & 0.053 & 70 \\
\hline PCB 167 & 0.232 & 0.286 & 0.660 & 1.74 & 0.684 & 0.720 & 0.61 & 84 \\
\hline PCB 170 & 3.63 & 1.67 & 3.14 & 10.7 & 4.10 & 4.65 & 3.5 & 75 \\
\hline PCB 172 & 0.909 & 0.512 & 1.17 & 2.51 & 0.889 & 1.20 & 0.77 & 64 \\
\hline PCB 174 & 0.0735 & 0.0412 & 0.118 & 0.156 & 0.494 & 0.176 & 0.18 & 100 \\
\hline PCB 175 & 0.151 & 0.0876 & 0.174 & 0.501 & 0.238 & 0.230 & 0.16 & 70 \\
\hline PCB 176 & $<$ LOQ & 0.00515 & 0.00503 & 0.0213 & 0.0544 & 0.0215 & 0.023 & 110 \\
\hline PCB 177 & 0.738 & 0.137 & 0.631 & 2.86 & 2.50 & 1.37 & 1.2 & 89 \\
\hline PCB 178 & 0.653 & 0.141 & 0.517 & 3.48 & 1.00 & 1.16 & 1.3 & 120 \\
\hline PCB $180+193$ & 3.97 & 3.31 & 7.90 & 24.1 & 11.2 & 10.1 & 8.5 & 84 \\
\hline PCB 183 & 1.84 & 0.952 & 2.22 & 6.54 & 3.16 & 2.94 & 2.2 & 73 \\
\hline PCB 185 & $<\mathrm{LOQ}$ & 0.0160 & 0.0636 & 0.122 & 0.136 & 0.0844 & 0.055 & 66 \\
\hline PCB 187 & 6.90 & 2.56 & 6.47 & 31.1 & 9.47 & 11.3 & 11 & 100 \\
\hline PCB 188 & 0.0174 & 0.0148 & 0.0344 & 0.0906 & 0.0361 & 0.0386 & 0.031 & 79 \\
\hline PCB 189 & 0.181 & 0.102 & $<\mathrm{LOQ}$ & 0.412 & 0.0222 & 0.179 & 0.17 & 94 \\
\hline PCB 191 & 0.0679 & 0.0147 & 0.0619 & 0.158 & 0.151 & 0.0908 & 0.062 & 68 \\
\hline PCB 194 & 1.73 & 0.826 & 2.50 & 5.02 & 1.60 & 2.33 & 1.6 & 69 \\
\hline PCB 195 & 0.571 & 0.304 & 0.653 & 1.37 & 0.479 & 0.676 & 0.41 & 61 \\
\hline PCB 196 & 1.60 & 0.985 & 1.86 & 4.58 & 1.70 & 2.15 & 1.4 & 65 \\
\hline PCB 197 & 0.115 & 0.0471 & 0.0965 & 0.323 & 0.191 & 0.154 & 0.11 & 70 \\
\hline PCB 199 & 8.04 & 4.35 & 9.08 & 24.0 & 6.96 & 10.5 & 7.7 & 74 \\
\hline PCB 200 & $<\mathrm{LOD}$ & $<\mathrm{LOD}$ & $<\mathrm{LOD}$ & $<\mathrm{LOD}$ & $<\mathrm{LOD}$ & $<$ LOD & & \\
\hline PCB 201 & 1.87 & 1.09 & 2.01 & 5.57 & 1.88 & 2.48 & 1.8 & 71 \\
\hline PCB 202 & 0.0649 & $<$ LOQ & 0.0529 & 0.120 & 0.295 & 0.133 & 0.11 & 84 \\
\hline PCB 205 & 0.0918 & 0.0278 & 0.101 & 0.206 & 0.0700 & 0.0993 & 0.066 & 67 \\
\hline PCB 206 & 0.609 & 0.434 & 0.747 & 2.15 & 0.651 & 0.918 & 0.70 & 76 \\
\hline PCB 207 & 0.0868 & 0.0796 & 0.136 & 0.302 & 0.140 & 0.149 & 0.090 & 60 \\
\hline PCB 208 & 0.213 & 0.0654 & 0.182 & 0.681 & 0.179 & 0.264 & 0.24 & 91 \\
\hline PCB 209 & 0.316 & 0.298 & 0.376 & 1.12 & 0.346 & 0.490 & 0.35 & 72 \\
\hline
\end{tabular}


Appendix 42. Brominated diphenyl ether (BDE) and polychlorinated biphenyl (PCB) mass fractions (ng g ${ }^{-1}$ wet mass) in thick-billed murre eggs collected at St. Lazaria Island, Alaska in 2008 (compounds shown in red and blue were above and below reference value ranges, respectively).

\begin{tabular}{|c|c|c|c|c|c|c|c|c|}
\hline Compound & 1242 & 1243 & 1244 & 1245 & 1246 & Mean & SD & RSD \\
\hline BDE47 & 0.806 & 1.17 & 0.877 & 10.7 & 6.82 & 4.09 & 4.5 & 110 \\
\hline BDE99 & 0.994 & 1.48 & 1.07 & 3.26 & 3.17 & 1.99 & 1.1 & 57 \\
\hline BDE100 & 0.734 & 0.703 & 0.501 & 2.94 & 1.98 & 1.37 & 1.1 & 77 \\
\hline PCB 8 & 0.0126 & 0.0222 & $<\mathrm{LOD}$ & $<$ LOD & $<\mathrm{LOD}$ & 0.0174 & 0.0067 & 39 \\
\hline PCB 18 & $<\mathrm{LOD}$ & $<\mathrm{LOD}$ & $<\mathrm{LOD}$ & $<\mathrm{LOD}$ & 0.0324 & $<$ LOD & & \\
\hline PCB 28+31 & 2.11 & 1.60 & 1.97 & 2.26 & 2.32 & 2.05 & 0.29 & 14 \\
\hline РCB 29 & $<$ LOQ & $<\mathrm{LOQ}$ & $<\mathrm{LOQ}$ & $<$ LOQ & $<\mathrm{LOQ}$ & $<$ LOQ & & \\
\hline РCB 44 & $<$ LOQ & $<\mathrm{LOQ}$ & $<\mathrm{LOQ}$ & 0.0960 & 0.0740 & 0.0850 & 0.016 & 18 \\
\hline РCB 45 & $<\mathrm{LOQ}$ & $<\mathrm{LOQ}$ & $<\mathrm{LOQ}$ & $<$ LOQ & $<$ LOQ & $<$ LOQ & & \\
\hline PCB 49 & $<\mathrm{LOQ}$ & $<\mathrm{LOQ}$ & $<\mathrm{LOQ}$ & 0.124 & 0.121 & 0.122 & 0.0019 & 1.6 \\
\hline PCB 52 & 0.0380 & 0.0317 & 0.0227 & 0.281 & 0.246 & 0.124 & 0.13 & 100 \\
\hline PCB 56 & $<\mathrm{LOQ}$ & $<\mathrm{LOQ}$ & $<\mathrm{LOQ}$ & $<\mathrm{LOQ}$ & $<\mathrm{LOQ}$ & $<\mathbf{L O Q}$ & & \\
\hline PCB 63 & $<$ LOQ & $<$ LOQ & $<\mathrm{LOQ}$ & 0.196 & $<$ LOQ & 0.196 & & \\
\hline PCB 66 & 2.36 & 2.11 & 2.11 & 2.64 & 3.34 & 2.51 & 0.51 & 20 \\
\hline PCB 70 & 0.0227 & $<\mathrm{LOD}$ & $<\mathrm{LOD}$ & 0.155 & 0.120 & 0.0992 & 0.069 & 69 \\
\hline PCB 74 & 1.69 & 1.55 & 1.71 & 2.04 & 2.49 & 1.90 & 0.38 & 20 \\
\hline РCB 79 & $<\mathrm{LOQ}$ & $<\mathrm{LOQ}$ & $<\mathrm{LOQ}$ & $<\mathrm{LOQ}$ & $<\mathrm{LOQ}$ & $<$ LOQ & & \\
\hline PCB 82 & $<\mathrm{LOD}$ & $<\mathrm{LOD}$ & $<\mathrm{LOD}$ & $<\mathrm{LOD}$ & $<\mathrm{LOD}$ & $<$ LOD & & \\
\hline РCB 87 & 0.0387 & 0.0524 & 0.0865 & 0.190 & 0.131 & 0.0997 & 0.062 & 62 \\
\hline РCB 92 & 0.0333 & 0.0335 & 0.0281 & 0.0951 & 0.100 & 0.0581 & 0.036 & 62 \\
\hline PCB 95+121 & $<\mathrm{LOD}$ & $<\mathrm{LOD}$ & $<\mathrm{LOD}$ & $<\mathrm{LOD}$ & $<\mathrm{LOD}$ & $<$ LOD & & \\
\hline PCB 99 & 2.12 & 1.80 & 3.29 & 7.14 & 7.35 & 4.34 & 2.7 & 62 \\
\hline PCB 101 & $<\mathrm{LOD}$ & $<$ LOD & $<\mathrm{LOD}$ & 0.228 & 0.262 & 0.245 & 0.024 & 9.6 \\
\hline PCB 105 & 2.27 & 2.94 & 2.40 & 3.19 & 3.28 & 2.82 & 0.46 & 16 \\
\hline PCB 106 & 0.0216 & $<\mathrm{LOQ}$ & 0.0207 & 0.0163 & $<\mathrm{LOQ}$ & 0.0196 & 0.0029 & 15 \\
\hline PCB 107 & 0.468 & 0.641 & 0.680 & 0.699 & 0.598 & 0.617 & 0.092 & 15 \\
\hline PCB 110 & $<\mathrm{LOD}$ & $<\mathrm{LOD}$ & $<\mathrm{LOD}$ & $<\mathrm{LOD}$ & $<\mathrm{LOD}$ & $<$ LOD & & \\
\hline PCB 112 & $<$ LOD & $<\mathrm{LOD}$ & $<$ LOD & $<\mathrm{LOD}$ & $<$ LOD & $<$ LOD & & \\
\hline PCB 114 & 0.277 & 0.351 & 0.232 & 0.299 & 0.394 & 0.310 & 0.063 & 20 \\
\hline PCB 118 & 7.12 & 8.34 & 7.80 & 11.1 & 11.0 & 9.07 & 1.9 & 20 \\
\hline PCB 119 & 0.0390 & 0.0508 & 0.0772 & 0.203 & 0.192 & 0.113 & 0.079 & 70 \\
\hline PCB 127 & $<\mathrm{LOD}$ & $<\mathrm{LOD}$ & $<\mathrm{LOD}$ & $<\mathrm{LOD}$ & $<\mathrm{LOD}$ & $<$ LOD & & \\
\hline PCB 128 & 0.466 & 0.699 & 1.27 & 1.82 & 1.55 & 1.16 & 0.57 & 49 \\
\hline PCB 130 & 0.345 & 0.545 & 0.657 & 0.875 & 0.610 & 0.606 & 0.19 & 32 \\
\hline PCB 137 & 0.0447 & 0.0729 & 0.166 & 0.419 & 0.427 & 0.226 & 0.19 & 82 \\
\hline PCB 138 & 2.78 & 3.49 & 5.99 & 13.9 & 10.4 & 7.32 & 4.8 & 65 \\
\hline PCB 146 & 3.17 & 4.36 & 4.10 & 6.44 & 5.37 & 4.69 & 1.3 & 27 \\
\hline PCB 149 & 0.263 & 0.348 & 0.294 & 0.747 & 0.681 & 0.467 & 0.23 & 49 \\
\hline
\end{tabular}


Appendix 42 (Continued).

\begin{tabular}{|c|c|c|c|c|c|c|c|c|}
\hline Compound & 1242 & 1243 & 1244 & 1245 & 1246 & Mean & SD & RSD \\
\hline PCB 151 & $<$ LOQ & 0.0810 & $<$ LOQ & 0.159 & 0.169 & 0.136 & 0.048 & 35 \\
\hline PCB $153+132$ & 8.37 & 10.0 & 12.4 & 32.3 & 23.1 & 17.2 & 10 & 59 \\
\hline PCB 154 & $<\mathrm{LOQ}$ & 0.0719 & 0.109 & 0.151 & 0.160 & 0.123 & 0.041 & 33 \\
\hline PCB 156 & 1.00 & 1.55 & 1.00 & 1.39 & 1.31 & 1.25 & 0.24 & 19 \\
\hline PCB 157 & 0.213 & 0.302 & 0.248 & 0.330 & 0.320 & 0.283 & 0.050 & 18 \\
\hline PCB 158 & 0.156 & 0.282 & 0.340 & 0.763 & 0.536 & 0.415 & 0.24 & 57 \\
\hline РCB 159 & $<\mathrm{LOQ}$ & $<\mathrm{LOQ}$ & $<\mathrm{LOQ}$ & $<\mathrm{LOQ}$ & 0.0324 & $<\mathrm{LOQ}$ & & \\
\hline PCB 163 & 2.24 & 3.99 & 4.35 & 6.03 & 4.37 & 4.19 & 1.3 & 32 \\
\hline PCB 165 & 0.0355 & 0.0669 & 0.0428 & 0.0593 & 0.0613 & 0.0532 & 0.013 & 25 \\
\hline PCB 166 & 0.0536 & 0.0817 & 0.0410 & 0.0592 & 0.0747 & 0.0620 & 0.016 & 26 \\
\hline PCB 167 & 0.447 & 0.529 & 0.379 & 0.819 & 0.860 & 0.607 & 0.22 & 36 \\
\hline PCB 170 & 2.09 & 4.24 & 3.19 & 5.85 & 3.53 & 3.78 & 1.4 & 37 \\
\hline PCB 172 & 0.983 & 1.60 & 0.899 & 1.51 & 1.25 & 1.25 & 0.31 & 25 \\
\hline PCB 174 & 0.0519 & 0.0784 & 0.0515 & 0.104 & 0.0987 & 0.0769 & 0.025 & 32 \\
\hline PCB 175 & 0.106 & 0.171 & 0.161 & 0.236 & 0.193 & 0.173 & 0.047 & 27 \\
\hline PCB 176 & $<\mathrm{LOQ}$ & 0.00780 & 0.00801 & 0.0210 & 0.0309 & 0.0169 & 0.011 & 66 \\
\hline PCB 177 & 0.139 & 0.326 & 0.810 & 1.03 & 0.712 & 0.603 & 0.36 & 60 \\
\hline PCB 178 & 0.431 & 1.14 & 0.732 & 0.934 & 0.819 & 0.811 & 0.26 & 32 \\
\hline PCB $180+193$ & 2.57 & 4.51 & 4.19 & 12.2 & 7.39 & 6.17 & 3.8 & 61 \\
\hline PCB 183 & 1.39 & 2.01 & 1.31 & 3.03 & 2.36 & 2.02 & 0.71 & 35 \\
\hline PCB 185 & 0.0254 & 0.0339 & 0.0107 & 0.0537 & 0.0741 & 0.0395 & 0.025 & 63 \\
\hline PCB 187 & 2.17 & 4.65 & 6.74 & 10.7 & 7.18 & 6.29 & 3.2 & 50 \\
\hline PCB 188 & 0.0311 & 0.0400 & 0.0223 & 0.0297 & 0.0440 & 0.0334 & 0.0086 & 26 \\
\hline PCB 189 & 0.181 & 0.345 & 0.0258 & 0.310 & 0.236 & 0.219 & 0.13 & 57 \\
\hline PCB 191 & $<\mathrm{LOQ}$ & 0.0382 & 0.0524 & 0.0733 & 0.0651 & 0.0573 & 0.015 & 27 \\
\hline PCB 194 & 1.67 & 3.36 & 1.94 & 3.22 & 2.09 & 2.46 & 0.78 & 32 \\
\hline PCB 195 & 0.487 & 0.980 & 0.516 & 0.851 & 0.682 & 0.703 & 0.21 & 30 \\
\hline РCВ 196 & 1.16 & 1.88 & 1.35 & 2.44 & 1.83 & 1.73 & 0.50 & 29 \\
\hline PCB 197 & 0.0889 & 0.110 & 0.0887 & 0.170 & 0.118 & 0.115 & 0.033 & 29 \\
\hline PCB 199 & 6.14 & 11.7 & 7.42 & 11.9 & 9.11 & 9.24 & 2.5 & 27 \\
\hline PCB 200 & $<\mathrm{LOD}$ & $<\mathrm{LOD}$ & $<$ LOD & $<\mathrm{LOD}$ & $<$ LOD & $<$ LOD & & \\
\hline РCB 201 & 0.938 & 2.00 & 1.48 & 2.97 & 1.98 & 1.87 & 0.75 & 40 \\
\hline PCB 202 & 0.0501 & 0.155 & 0.0697 & 0.0628 & 0.0771 & 0.0829 & 0.041 & 50 \\
\hline PCB 205 & 0.103 & 0.153 & 0.0634 & 0.138 & 0.117 & 0.115 & 0.035 & 30 \\
\hline PCB 206 & 0.556 & 1.13 & 0.680 & 1.18 & 0.773 & 0.863 & 0.28 & 32 \\
\hline PCB 207 & 0.0791 & 0.128 & 0.0857 & 0.163 & 0.130 & 0.117 & 0.035 & 30 \\
\hline РCB 208 & 0.167 & 0.323 & 0.194 & 0.360 & 0.203 & 0.249 & 0.086 & 34 \\
\hline РСВ 209 & 0.277 & 0.547 & 0.296 & 0.608 & 0.385 & 0.423 & 0.15 & 35 \\
\hline
\end{tabular}


Appendix 43. Brominated diphenyl ether (BDE) and polychlorinated biphenyl (PCB) mass fractions (ng $\mathrm{g}^{-1}$ wet mass) in glaucous gull eggs collected at the Kukpuk River delta, Alaska in 2008 (compounds shown in red and blue were above and below reference value ranges, respectively).

\begin{tabular}{|c|c|c|c|c|c|c|c|c|}
\hline Compound & 1349 & 1351 & 1354 & 1357 & 1358 & Mean & SD & RSD \\
\hline BDE47 & 141 & 5.48 & 6.12 & 126 & 152 & 86.0 & 74 & 86 \\
\hline BDE99 & 156 & 5.42 & 5.29 & 134 & 147 & 89.5 & 77 & 86 \\
\hline BDE100 & 30.0 & 2.03 & 2.03 & 25.9 & 28.5 & 17.7 & 14 & 81 \\
\hline PCB 8 & $<\mathrm{LOD}$ & $<\mathrm{LOD}$ & $<\mathrm{LOD}$ & $<\mathrm{LOD}$ & $<\mathrm{LOD}$ & $<$ LOD & & \\
\hline PCB 18 & $<\mathrm{LOD}$ & $<\mathrm{LOD}$ & $<\mathrm{LOD}$ & $<\mathrm{LOD}$ & $<\mathrm{LOD}$ & $<$ LOD & & \\
\hline PCB $28+31$ & 1.72 & 3.78 & 3.96 & 1.53 & 1.70 & 2.53 & 1.2 & 48 \\
\hline PCB 29 & $<$ LOQ & $<\mathrm{LOQ}$ & $<\mathrm{LOQ}$ & $<$ LOQ & $<$ LOQ & $<$ LOQ & & \\
\hline PCB 44 & 0.0593 & 0.325 & 0.259 & 0.0939 & 0.0606 & 0.159 & 0.12 & 78 \\
\hline PCB 45 & $<\mathrm{LOQ}$ & $<$ LOQ & $<$ LOQ & $<$ LOQ & $<$ LOQ & $<$ LOQ & & \\
\hline РCB 49 & 0.370 & 1.77 & 1.82 & 0.331 & 0.376 & 0.933 & 0.79 & 84 \\
\hline РCB 52 & 0.762 & 15.8 & 17.0 & 0.705 & 0.789 & 7.02 & 8.6 & 120 \\
\hline РCB 56 & $<$ LOQ & $<$ LOQ & $<\mathrm{LOQ}$ & $<$ LOQ & $<$ LOQ & $<$ LOQ & & \\
\hline РCB 63 & $<$ LOQ & $<$ LOQ & $<\mathrm{LOQ}$ & $<$ LOQ & $<$ LOQ & $<$ LOQ & & \\
\hline РCB 66 & 2.30 & 6.94 & 7.15 & 2.32 & 2.40 & 4.22 & 2.6 & 61 \\
\hline PCB 70 & $<\mathrm{LOD}$ & 0.0676 & 0.0247 & 0.0237 & $<\mathrm{LOD}$ & 0.0387 & 0.025 & 65 \\
\hline РCB 74 & 2.26 & 8.04 & 8.44 & 2.22 & 2.34 & 4.66 & 3.3 & 70 \\
\hline PCB 79 & $<$ LOQ & 0.0144 & $<$ LOQ & $<\mathrm{LOQ}$ & $<$ LOQ & $<$ LOQ & & \\
\hline PCB 82 & 0.0190 & 0.0939 & 0.0409 & $<\mathrm{LOD}$ & $<\mathrm{LOD}$ & 0.0513 & 0.039 & 75 \\
\hline PCB 87 & 0.546 & 3.48 & 3.29 & 0.452 & 0.504 & 1.65 & 1.6 & 96 \\
\hline PCB 92 & 0.152 & 5.49 & 5.52 & 0.147 & 0.157 & 2.29 & 2.9 & 130 \\
\hline PCB 95+121 & 0.162 & 3.80 & 3.58 & 0.0995 & 0.188 & 1.56 & 1.9 & 120 \\
\hline РCB 99 & 14.8 & 48.8 & 48.3 & 12.9 & 16.2 & 28.2 & 19 & 66 \\
\hline PCB 101 & 2.56 & 18.7 & 18.5 & 2.20 & 2.68 & 8.92 & 8.8 & 99 \\
\hline PCB 105 & 2.93 & 12.1 & 14.3 & 2.58 & 3.10 & 7.00 & 5.7 & 82 \\
\hline PCB 106 & 0.0172 & $<\mathrm{LOQ}$ & 0.0871 & $<\mathrm{LOQ}$ & $<$ LOQ & 0.0521 & 0.049 & 95 \\
\hline PCB 107 & 0.0697 & 0.388 & 0.445 & 0.0389 & 0.0642 & 0.201 & 0.20 & 98 \\
\hline PCB 110 & 1.83 & 7.39 & 8.35 & 1.58 & 1.90 & 4.21 & 3.4 & 80 \\
\hline PCB 112 & $<\mathrm{LOD}$ & $<\mathrm{LOD}$ & $<$ LOD & $<\mathrm{LOD}$ & $<\mathrm{LOD}$ & $<$ LOD & & \\
\hline PCB 114 & 0.336 & 1.11 & 1.29 & 0.301 & 0.316 & 0.670 & 0.49 & 73 \\
\hline PCB 118 & 13.0 & 48.8 & 55.3 & 11.8 & 13.9 & 28.5 & 22 & 76 \\
\hline PCB 119 & 0.324 & 1.19 & 1.18 & 0.292 & 0.342 & 0.666 & 0.47 & 71 \\
\hline PCB 127 & $<\mathrm{LOD}$ & $<\mathrm{LOD}$ & $<\mathrm{LOD}$ & $<\mathrm{LOD}$ & $<\mathrm{LOD}$ & $<$ LOD & & \\
\hline PCB 128 & 2.38 & 9.37 & 10.1 & 2.33 & 2.56 & 5.35 & 4.0 & 75 \\
\hline PCB 130 & 0.780 & 2.57 & 2.69 & 0.693 & 0.732 & 1.49 & 1.0 & 70 \\
\hline PCB 137 & 1.37 & 4.25 & 4.64 & 1.22 & 1.35 & 2.57 & 1.7 & 67 \\
\hline PCB 138 & 19.8 & 68.3 & 76.4 & 18.4 & 21.6 & 40.9 & 29 & 71 \\
\hline PCB 146 & 4.79 & 15.4 & 16.9 & 4.49 & 5.07 & 9.33 & 6.3 & 67 \\
\hline PCB 149 & 1.82 & 13.7 & 14.3 & 1.66 & 1.91 & 6.67 & 6.7 & 100 \\
\hline
\end{tabular}


Appendix 43 (Continued).

\begin{tabular}{|c|c|c|c|c|c|c|c|c|}
\hline Compound & 1349 & 1351 & 1354 & 1357 & 1358 & Mean & SD & RSD \\
\hline PCB 151 & 0.209 & 4.41 & 4.64 & 0.231 & 0.238 & 1.95 & 2.4 & 120 \\
\hline PCB $153+132$ & 48.8 & 138 & 154 & 44.4 & 51.0 & 87.3 & 54 & 62 \\
\hline PCB 154 & 0.445 & 1.45 & 1.59 & 0.392 & 0.487 & 0.872 & 0.59 & 68 \\
\hline PCB 156 & 1.29 & 3.38 & 3.58 & 1.13 & 1.29 & 2.14 & 1.2 & 58 \\
\hline PCB 157 & 0.463 & 1.10 & 1.14 & 0.424 & 0.462 & 0.718 & 0.37 & 51 \\
\hline PCB 158 & 1.14 & 5.30 & 5.04 & 1.37 & 1.18 & 2.81 & 2.2 & 77 \\
\hline PCB 159 & $<\mathrm{LOQ}$ & $<\mathrm{LOQ}$ & $<\mathrm{LOQ}$ & $<$ LOQ & $<\mathrm{LOQ}$ & $<\mathrm{LOQ}$ & & \\
\hline PCB 163 & 4.47 & 15.2 & 16.7 & 4.52 & 5.22 & 9.22 & 6.2 & 67 \\
\hline PCB 165 & 0.0482 & 0.112 & 0.125 & 0.0307 & 0.0377 & 0.0707 & 0.044 & 63 \\
\hline PCB 166 & 0.102 & 0.284 & 0.315 & 0.0879 & 0.0902 & 0.176 & 0.11 & 65 \\
\hline PCB 167 & 0.651 & 2.80 & 3.14 & 0.551 & 0.691 & 1.57 & 1.3 & 82 \\
\hline PCB 170 & 4.75 & 10.4 & 11.2 & 4.35 & 4.78 & 7.11 & 3.4 & 48 \\
\hline PCB 172 & 0.520 & 1.74 & 1.74 & 0.511 & 0.556 & 1.01 & 0.66 & 65 \\
\hline PCB 174 & 0.276 & 1.74 & 1.85 & 0.230 & 0.255 & 0.870 & 0.85 & 97 \\
\hline PCB 175 & 0.188 & 0.675 & 0.721 & 0.179 & 0.193 & 0.391 & 0.28 & 72 \\
\hline PCB 176 & 0.0133 & 0.115 & 0.121 & 0.0306 & 0.0324 & 0.0624 & 0.051 & 82 \\
\hline PCB 177 & 0.392 & 1.78 & 1.92 & 0.351 & 0.385 & 0.966 & 0.81 & 84 \\
\hline PCB 178 & 0.322 & 3.57 & 4.01 & 0.260 & 0.394 & 1.71 & 1.9 & 110 \\
\hline PCB $180+193$ & 11.9 & 28.8 & 30.6 & 10.8 & 12.0 & 18.8 & 10 & 53 \\
\hline PCB 183 & 3.04 & 10.2 & 11.3 & 2.64 & 3.07 & 6.06 & 4.3 & 71 \\
\hline PCB 185 & 0.0238 & 0.220 & 0.267 & $<\mathrm{LOQ}$ & $<\mathrm{LOQ}$ & 0.170 & 0.13 & 76 \\
\hline PCB 187 & 4.51 & 20.8 & 23.2 & 3.79 & 4.48 & 11.4 & 9.7 & 86 \\
\hline PCB 188 & 0.0154 & 0.0602 & 0.0817 & 0.00323 & 0.0134 & 0.0348 & 0.034 & 98 \\
\hline PCB 189 & 0.147 & 0.0501 & 0.0224 & $<\mathrm{LOQ}$ & 0.0448 & 0.0659 & 0.055 & 83 \\
\hline PCB 191 & 0.104 & 0.349 & 0.356 & 0.124 & 0.138 & 0.214 & 0.13 & 59 \\
\hline PCB 194 & 1.64 & 2.51 & 2.69 & 1.43 & 1.71 & 2.00 & 0.57 & 28 \\
\hline PCB 195 & 0.272 & 0.611 & 0.606 & 0.250 & 0.265 & 0.401 & 0.19 & 47 \\
\hline PCB 196 & 1.36 & 3.22 & 3.24 & 1.27 & 1.38 & 2.10 & 1.0 & 50 \\
\hline PCB 197 & 0.131 & 0.307 & 0.286 & 0.137 & 0.117 & 0.195 & 0.093 & 47 \\
\hline PCB 199 & 3.69 & 9.78 & 10.1 & 3.17 & 3.25 & 6.01 & 3.6 & 60 \\
\hline PCB 200 & $<\mathrm{LOD}$ & $<\mathrm{LOD}$ & $<\mathrm{LOD}$ & $<\mathrm{LOD}$ & $<\mathrm{LOD}$ & $<$ LOD & & \\
\hline PCB 201 & 0.706 & 3.28 & 2.85 & 0.799 & 0.648 & 1.66 & 1.3 & 78 \\
\hline PCB 202 & 0.181 & 1.07 & 1.12 & 0.185 & 0.191 & 0.550 & 0.50 & 91 \\
\hline PCB 205 & 0.0923 & 0.102 & 0.124 & 0.0644 & 0.0631 & 0.0891 & 0.026 & 29 \\
\hline PCB 206 & 0.357 & 0.636 & 0.636 & 0.350 & 0.291 & 0.454 & 0.17 & 37 \\
\hline PCB 207 & 0.0885 & 0.176 & 0.214 & 0.0819 & 0.0932 & 0.131 & 0.060 & 46 \\
\hline PCB 208 & 0.0757 & 0.152 & 0.224 & 0.0261 & 0.0597 & 0.107 & 0.080 & 74 \\
\hline PCB 209 & 0.118 & 0.250 & 0.256 & 0.101 & 0.125 & 0.170 & 0.076 & 45 \\
\hline
\end{tabular}


Appendix 44. Brominated diphenyl ether (BDE) and polychlorinated biphenyl (PCB) mass fractions (ng g ${ }^{-1}$ wet mass) in glaucous gull eggs collected at Shishmaref Inlet, Alaska in 2008 (compounds shown in red and blue were above and below reference value ranges, respectively).

\begin{tabular}{|c|c|c|c|c|c|c|c|c|}
\hline Compound & 1407 & 1411 & 1414 & 1415 & 1416 & Mean & SD & RSD \\
\hline BDE47 & 1.53 & 2.16 & 82.9 & 1.95 & 1.66 & 18.0 & 36 & 200 \\
\hline BDE99 & 1.06 & 1.12 & 86.8 & 1.40 & 1.32 & 18.3 & 38 & 210 \\
\hline BDE100 & 0.741 & 0.824 & 19.7 & 0.920 & 0.835 & 4.59 & 8.4 & 180 \\
\hline PCB 8 & $<\mathrm{LOD}$ & $<\mathrm{LOD}$ & $<\mathrm{LOD}$ & $<\mathrm{LOD}$ & $<\mathrm{LOD}$ & $<$ LOD & & \\
\hline PCB 18 & $<\mathrm{LOD}$ & 0.0869 & $<\mathrm{LOD}$ & 0.157 & $<\mathrm{LOD}$ & 0.122 & 0.050 & 41 \\
\hline PCB $28+31$ & 4.20 & 5.82 & 4.19 & 5.11 & 4.26 & 4.72 & 0.73 & 15 \\
\hline РCB 29 & $<\mathrm{LOQ}$ & $<\mathrm{LOQ}$ & $<\mathrm{LOQ}$ & $<\mathrm{LOQ}$ & $<\mathrm{LOQ}$ & $<$ LOQ & & \\
\hline PCB 44 & 0.0576 & 0.102 & 0.130 & 0.345 & 0.0736 & 0.142 & 0.12 & 83 \\
\hline PCB 45 & $<\mathrm{LOQ}$ & $<\mathrm{LOQ}$ & $<\mathrm{LOQ}$ & $<\mathrm{LOQ}$ & $<\mathrm{LOQ}$ & $<$ LOQ & & \\
\hline РCB 49 & 0.381 & 0.252 & 0.392 & 0.889 & 0.395 & 0.462 & 0.25 & 53 \\
\hline PCB 52 & 2.65 & 4.00 & 2.65 & 4.04 & 3.68 & 3.40 & 0.70 & 21 \\
\hline РCB 56 & $<\mathrm{LOQ}$ & $<$ LOQ & $<\mathrm{LOQ}$ & $<\mathrm{LOQ}$ & $<\mathrm{LOQ}$ & $<$ LOQ & & \\
\hline PCB 63 & $<\mathrm{LOQ}$ & 0.218 & $<\mathrm{LOQ}$ & 0.250 & $<\mathrm{LOQ}$ & 0.234 & 0.023 & 9.7 \\
\hline PCB 66 & 4.45 & 7.41 & 3.95 & 5.72 & 5.10 & 5.33 & 1.3 & 25 \\
\hline PCB 70 & 0.380 & 0.423 & 0.644 & 0.639 & 0.148 & 0.447 & 0.21 & 46 \\
\hline РCB 74 & 3.99 & 6.49 & 4.28 & 5.26 & 4.54 & 4.91 & 1.0 & 20 \\
\hline РCB 79 & $<$ LOQ & $<$ LOQ & $<\mathrm{LOQ}$ & $<\mathrm{LOQ}$ & $<$ LOQ & $<$ LOQ & & \\
\hline PCB 82 & 0.109 & 0.0713 & 0.0574 & 0.230 & 0.0563 & 0.105 & 0.073 & 70 \\
\hline РCB 87 & 0.834 & 1.29 & 0.762 & 1.61 & 1.02 & 1.10 & 0.35 & 32 \\
\hline PCB 92 & 0.887 & 1.86 & 1.02 & 1.84 & 1.28 & 1.38 & 0.45 & 33 \\
\hline PCB 95+121 & 0.336 & 0.541 & 0.397 & 0.919 & 0.369 & 0.512 & 0.24 & 47 \\
\hline PCB 99 & 16.6 & 31.2 & 19.2 & 20.0 & 19.8 & 21.3 & 5.7 & 27 \\
\hline PCB 101 & 4.88 & 5.73 & 4.32 & 7.10 & 6.71 & 5.75 & 1.2 & 21 \\
\hline PCB 105 & 4.45 & 11.4 & 4.47 & 6.37 & 5.23 & 6.39 & 2.9 & 46 \\
\hline PCB 106 & 0.0923 & 0.345 & 0.0523 & 0.0855 & $<$ LOQ & 0.144 & 0.14 & 94 \\
\hline PCB 107 & 0.364 & 0.683 & 0.433 & 0.540 & 0.267 & 0.458 & 0.16 & 35 \\
\hline PCB 110 & 3.77 & 6.36 & 2.50 & 4.76 & 3.93 & 4.27 & 1.4 & 33 \\
\hline PCB 112 & $<\mathrm{LOD}$ & $<\mathrm{LOD}$ & $<\mathrm{LOD}$ & $<\mathrm{LOD}$ & $<\mathrm{LOD}$ & $<$ LOD & & \\
\hline PCB 114 & 0.452 & 0.915 & 0.399 & 0.632 & 0.494 & 0.578 & 0.21 & 36 \\
\hline PCB 118 & 17.7 & 40.1 & 17.0 & 23.4 & 21.1 & 23.8 & 9.4 & 40 \\
\hline PCB 119 & 0.365 & 0.776 & 0.375 & 0.484 & 0.465 & 0.493 & 0.17 & 34 \\
\hline PCB 127 & $<\mathrm{LOD}$ & $<\mathrm{LOD}$ & $<\mathrm{LOD}$ & 0.0156 & $<\mathrm{LOD}$ & $<$ LOD & & \\
\hline PCB 128 & 3.12 & 6.67 & 3.25 & 4.04 & 3.71 & 4.16 & 1.4 & 35 \\
\hline PCB 130 & 1.02 & 1.86 & 0.995 & 1.52 & 1.22 & 1.32 & 0.37 & 28 \\
\hline PCB 137 & 1.38 & 3.12 & 1.26 & 2.01 & 1.54 & 1.86 & 0.76 & 41 \\
\hline PCB 138 & 22.7 & 45.6 & 27.7 & 31.1 & 26.5 & 30.7 & 8.8 & 29 \\
\hline PCB 146 & 5.68 & 9.88 & 6.47 & 8.36 & 6.89 & 7.45 & 1.7 & 22 \\
\hline PCB 149 & 3.05 & 4.52 & 2.50 & 4.29 & 3.36 & 3.55 & 0.85 & 24 \\
\hline
\end{tabular}


Appendix 44 (Continued).

\begin{tabular}{|c|c|c|c|c|c|c|c|c|}
\hline Compound & 1407 & 1411 & 1414 & 1415 & 1416 & Mean & SD & RSD \\
\hline PCB 151 & 0.373 & 0.787 & 0.575 & 1.19 & 0.460 & 0.677 & 0.33 & 48 \\
\hline PCB $153+132$ & 44.3 & 82.2 & 60.5 & 63.3 & 52.6 & 60.6 & 14 & 23 \\
\hline PCB 154 & 0.589 & 1.06 & 0.657 & 0.805 & 0.693 & 0.761 & 0.19 & 24 \\
\hline PCB 156 & 1.29 & 3.08 & 1.38 & 1.63 & 1.40 & 1.76 & 0.75 & 43 \\
\hline PCB 157 & 0.379 & 0.911 & 0.472 & 0.497 & 0.462 & 0.544 & 0.21 & 39 \\
\hline PCB 158 & 1.58 & 2.85 & 1.77 & 2.32 & 1.72 & 2.05 & 0.53 & 26 \\
\hline РCB 159 & $<\mathrm{LOQ}$ & $<\mathrm{LOQ}$ & $<\mathrm{LOQ}$ & $<\mathrm{LOQ}$ & $<\mathrm{LOQ}$ & $<$ LOQ & & \\
\hline PCB 163 & 5.72 & 9.45 & 5.94 & 6.84 & 6.02 & 6.79 & 1.5 & 23 \\
\hline PCB 165 & 0.0493 & 0.0620 & 0.0489 & 0.0762 & 0.0516 & 0.0576 & 0.012 & 20 \\
\hline PCB 166 & 0.0813 & 0.180 & 0.0848 & 0.147 & 0.0952 & 0.118 & 0.044 & 37 \\
\hline PCB 167 & 0.826 & 2.16 & 0.810 & 1.33 & 0.953 & 1.22 & 0.57 & 47 \\
\hline PCB 170 & 3.31 & 5.90 & 3.96 & 4.33 & 3.49 & 4.20 & 1.0 & 25 \\
\hline PCB 172 & 0.728 & 1.09 & 0.659 & 0.903 & 0.771 & 0.829 & 0.17 & 20 \\
\hline PCB 174 & 0.382 & 0.430 & 0.253 & 0.502 & 0.377 & 0.389 & 0.091 & 23 \\
\hline PCB 175 & 0.228 & 0.335 & 0.178 & 0.267 & 0.229 & 0.248 & 0.058 & 24 \\
\hline PCB 176 & $<\mathrm{LOQ}$ & 0.0332 & $<\mathrm{LOQ}$ & 0.0443 & 0.0477 & 0.0417 & 0.0076 & 18 \\
\hline РCB 177 & 0.755 & 0.920 & 0.644 & 0.859 & 0.653 & 0.766 & 0.12 & 16 \\
\hline РCB 178 & 0.672 & 1.28 & 0.825 & 1.27 & 0.919 & 0.993 & 0.27 & 27 \\
\hline PCB $180+193$ & 9.62 & 15.9 & 11.2 & 12.9 & 10.3 & 12.0 & 2.5 & 21 \\
\hline PCB 183 & 3.34 & 5.48 & 3.96 & 5.25 & 3.72 & 4.35 & 0.95 & 22 \\
\hline PCB 185 & 0.0565 & 0.0613 & 0.0430 & 0.0626 & 0.0336 & 0.0514 & 0.013 & 25 \\
\hline PCB 187 & 6.44 & 9.40 & 6.26 & 9.87 & 7.16 & 7.83 & 1.7 & 22 \\
\hline PCB 188 & 0.0172 & 0.0241 & 0.0145 & 0.0175 & 0.0214 & 0.0189 & 0.0038 & 20 \\
\hline РCB 189 & 0.0934 & 0.189 & 0.103 & 0.147 & 0.0414 & 0.115 & 0.056 & 49 \\
\hline РCB 191 & 0.117 & 0.216 & 0.0932 & 0.157 & 0.113 & 0.139 & 0.049 & 35 \\
\hline РCB 194 & 0.845 & 1.33 & 1.01 & 0.991 & 0.890 & 1.01 & 0.19 & 19 \\
\hline РCB 195 & 0.316 & 0.338 & 0.312 & 0.338 & 0.277 & 0.316 & 0.025 & 7.9 \\
\hline РCB 196 & 1.49 & 1.93 & 1.64 & 1.78 & 1.44 & 1.66 & 0.21 & 12 \\
\hline РCB 197 & 0.110 & 0.152 & 0.120 & 0.163 & 0.125 & 0.134 & 0.022 & 17 \\
\hline РСВ 199 & 4.50 & 5.23 & 3.91 & 5.14 & 4.28 & 4.61 & 0.56 & 12 \\
\hline PCB 200 & $<\mathrm{LOD}$ & $<\mathrm{LOD}$ & $<\mathrm{LOD}$ & $<\mathrm{LOD}$ & $<\mathrm{LOD}$ & $<$ LOD & & \\
\hline РCB 201 & 0.947 & 0.964 & 0.741 & 0.899 & 0.846 & 0.879 & 0.090 & 10 \\
\hline PCB 202 & 0.269 & 0.395 & 0.380 & 0.389 & 0.291 & 0.345 & 0.060 & 17 \\
\hline РCB 205 & 0.0749 & 0.0670 & 0.0199 & 0.0471 & 0.0311 & 0.0480 & 0.023 & 48 \\
\hline PCB 206 & 0.436 & 0.346 & 0.311 & 0.414 & 0.266 & 0.355 & 0.070 & 20 \\
\hline РCB 207 & 0.0906 & 0.139 & 0.108 & 0.107 & 0.101 & 0.109 & 0.018 & 17 \\
\hline РCB 208 & 0.322 & 0.119 & 0.0576 & 0.0622 & 0.0787 & 0.128 & 0.11 & 87 \\
\hline РCB 209 & 0.0889 & 0.137 & 0.161 & 0.143 & 0.0888 & 0.124 & 0.033 & 27 \\
\hline
\end{tabular}


Appendix 45. Brominated diphenyl ether (BDE) and polychlorinated biphenyl (PCB) mass fractions ( $\mathrm{ng} \mathrm{g}^{-1}$ wet mass) in glaucous gull eggs collected at Brevig Mission, Alaska in 2009 (compounds shown in red and blue were above and below reference value ranges, respectively).

\begin{tabular}{|c|c|c|c|c|c|c|c|c|}
\hline Compound & 1433 & 1435 & 1436 & 1439 & 1441 & Mean & SD & RSD \\
\hline BDE47 & 1.86 & 1.16 & 2.49 & 2.51 & 2.47 & 2.10 & 0.59 & 28 \\
\hline BDE99 & 0.404 & 0.241 & 0.376 & 0.524 & 0.407 & 0.391 & 0.10 & 26 \\
\hline BDE100 & 0.462 & 0.295 & 0.558 & 0.527 & 0.548 & 0.478 & 0.11 & 23 \\
\hline PCB 8 & $<$ LOD & $<\mathrm{LOD}$ & $<\mathrm{LOD}$ & $<\mathrm{LOD}$ & $<\mathrm{LOD}$ & $<$ LOD & & \\
\hline PCB 18 & $<$ LOD & $<\mathrm{LOD}$ & $<$ LOD & $<\mathrm{LOD}$ & $<\mathrm{LOD}$ & $<$ LOD & & \\
\hline PCB28+31 & 2.72 & 1.93 & 3.88 & 3.03 & 4.72 & 3.26 & 1.1 & 33 \\
\hline PCB 29 & $<$ LOD & $<$ LOD & $<\mathrm{LOD}$ & $<$ LOD & $<\mathrm{LOD}$ & $<$ LOD & & \\
\hline PCB 44 & 0.0682 & 0.114 & 0.0792 & 0.298 & 0.0624 & 0.124 & 0.099 & 80 \\
\hline PCB 45 & $<$ LOQ & $<$ LOQ & $<\mathrm{LOQ}$ & 0.00832 & 0.00864 & $<\mathrm{LOQ}$ & & \\
\hline PCB 49 & 0.0499 & 0.304 & 0.314 & 0.689 & 0.0581 & 0.283 & 0.26 & 92 \\
\hline PCB 52 & 0.574 & 1.77 & 1.45 & 6.15 & 1.38 & 2.27 & 2.2 & 98 \\
\hline PCB 56 & 0.338 & 0.143 & 0.250 & 0.253 & 0.347 & 0.266 & 0.083 & 31 \\
\hline PCB 63 & 0.0733 & 0.0855 & 0.115 & 0.122 & 0.182 & 0.115 & 0.042 & 37 \\
\hline PCB 66 & 4.41 & 2.75 & 5.98 & 5.39 & 6.20 & 4.95 & 1.4 & 28 \\
\hline PCB 70 & 0.0498 & 0.141 & 0.0931 & 0.161 & 0.0939 & 0.108 & 0.044 & 41 \\
\hline PCB 74 & 4.01 & 2.25 & 5.62 & 5.45 & 5.57 & 4.58 & 1.5 & 32 \\
\hline PCB 79 & $<$ LOQ & $<$ LOQ & 0.0297 & 0.0263 & 0.0267 & 0.0276 & 0.0018 & 6.6 \\
\hline PCB 82 & 0.0362 & 0.0469 & 0.0426 & 0.162 & 0.0279 & 0.0632 & 0.056 & 88 \\
\hline PCB 87 & 0.524 & 0.753 & 1.08 & 1.51 & 0.701 & 0.915 & 0.39 & 43 \\
\hline PCB 92 & 0.476 & 0.824 & 1.07 & 2.51 & 0.600 & 1.10 & 0.82 & 75 \\
\hline PCB 95+121 & 0.164 & 0.194 & 0.209 & 2.38 & 0.0605 & 0.601 & 0.99 & 170 \\
\hline РCB 99 & 20.5 & 11.7 & 30.0 & 29.1 & 27.0 & 23.6 & 7.6 & 32 \\
\hline PCB 101 & 1.86 & 4.38 & 3.73 & 11.0 & 2.39 & 4.67 & 3.7 & 79 \\
\hline PCB 105 & 5.12 & 3.38 & 7.66 & 6.92 & 6.94 & 6.01 & 1.7 & 29 \\
\hline PCB 106 & $<$ LOQ & $<\mathrm{LOQ}$ & 0.0297 & 0.0445 & 0.0710 & 0.0484 & 0.021 & 43 \\
\hline PCB 107 & 0.240 & 0.163 & 0.250 & 0.465 & 0.386 & 0.301 & 0.12 & 41 \\
\hline PCB 110 & 1.49 & 2.24 & 2.84 & 3.27 & 2.69 & 2.51 & 0.68 & 27 \\
\hline PCB 112 & 0.0333 & 0.0305 & 0.0643 & 0.0388 & 0.0458 & 0.0425 & 0.013 & 32 \\
\hline PCB 114 & 0.504 & 0.319 & 0.661 & 0.638 & 0.605 & 0.545 & 0.14 & 26 \\
\hline PCB 118 & 20.0 & 12.3 & 27.0 & 26.1 & 25.3 & 22.1 & 6.1 & 28 \\
\hline PCB 119 & 0.462 & 0.279 & 0.684 & 0.634 & 0.628 & 0.537 & 0.17 & 31 \\
\hline PCB 127 & $<$ LOQ & $<$ LOQ & $<$ LOQ & $<$ LOQ & $<\mathrm{LOQ}$ & $<\mathbf{L O Q}$ & & \\
\hline PCB 128 & 3.87 & 2.11 & 4.86 & 5.42 & 4.56 & 4.16 & 1.3 & 31 \\
\hline PCB 130 & 1.04 & 0.542 & 1.41 & 1.73 & 1.24 & 1.19 & 0.44 & 37 \\
\hline PCB 137 & 1.64 & 0.868 & 2.07 & 2.47 & 1.93 & 1.80 & 0.60 & 33 \\
\hline PCB 138 & 26.9 & 13.9 & 33.2 & 36.9 & 30.3 & 28.2 & 8.8 & 31 \\
\hline PCB 146 & 6.66 & 3.50 & 8.17 & 9.36 & 7.83 & 7.10 & 2.2 & 31 \\
\hline PCB 149 & 2.25 & 1.91 & 4.50 & 9.33 & 2.53 & 4.10 & 3.1 & 75 \\
\hline
\end{tabular}


Appendix 45 (Continued).

\begin{tabular}{|c|c|c|c|c|c|c|c|c|}
\hline Compound & 1433 & 1435 & 1436 & 1439 & 1441 & Mean & SD & RSD \\
\hline PCB 151 & 0.178 & 0.328 & 0.578 & 2.93 & 0.142 & 0.831 & 1.2 & 140 \\
\hline PCB $153+132$ & 55.5 & 27.6 & 64.3 & 78.7 & 61.6 & $\mathbf{5 7 . 5}$ & 19 & 33 \\
\hline РCB 154 & 0.664 & 0.388 & 0.857 & 0.966 & 0.820 & 0.739 & 0.22 & 30 \\
\hline PCB 156 & 1.35 & 0.836 & 1.81 & 1.77 & 1.71 & 1.49 & 0.41 & 28 \\
\hline PCB 157 & 0.395 & 0.238 & 0.471 & 0.558 & 0.482 & 0.429 & 0.12 & 28 \\
\hline PCB 158 & 0.992 & 0.619 & 1.49 & 1.76 & 1.54 & 1.28 & 0.46 & 36 \\
\hline PCB 159 & $<\mathrm{LOQ}$ & $<\mathrm{LOQ}$ & $<\mathrm{LOQ}$ & $<\mathrm{LOQ}$ & $<\mathrm{LOQ}$ & $<\mathbf{L O Q}$ & & \\
\hline PCB 163 & 5.82 & 2.84 & 7.96 & 9.01 & 6.68 & 6.46 & 2.4 & 37 \\
\hline PCB 165 & 0.0723 & 0.0400 & 0.0694 & 0.0912 & 0.0774 & 0.0700 & 0.019 & 27 \\
\hline PCB 166 & 0.0555 & 0.0688 & 0.169 & 0.130 & 0.177 & 0.120 & 0.056 & 47 \\
\hline PCB 167 & 1.07 & 0.664 & 1.23 & 1.43 & 1.29 & 1.14 & 0.29 & 26 \\
\hline PCB 170 & 4.28 & 2.21 & 4.24 & 6.17 & 4.40 & 4.26 & 1.4 & 33 \\
\hline PCB 172 & 0.822 & 0.412 & 0.914 & 1.29 & 0.855 & 0.858 & 0.31 & 36 \\
\hline PCB 174 & 0.357 & 0.271 & 0.575 & 1.48 & 0.342 & 0.605 & 0.50 & 83 \\
\hline PCB 175 & 0.327 & 0.163 & 0.354 & 0.472 & 0.354 & 0.334 & 0.11 & 33 \\
\hline PCB 176 & 0.0341 & 0.0422 & 0.0487 & 0.183 & 0.0385 & 0.0694 & 0.064 & 92 \\
\hline PCB 177 & 0.882 & 0.422 & 1.43 & 2.23 & 0.948 & 1.18 & 0.68 & 58 \\
\hline PCB 178 & 0.981 & 0.501 & 1.54 & 2.49 & 1.12 & 1.33 & 0.75 & 56 \\
\hline PCB 180+193 & 12.9 & 6.25 & 13.9 & 19.9 & 12.9 & 13.2 & 4.9 & 37 \\
\hline РCB 183 & 4.39 & 2.08 & 4.31 & 6.32 & 4.51 & 4.32 & 1.5 & 35 \\
\hline PCB 185 & 0.0146 & 0.0291 & 0.0303 & 0.175 & 0.0170 & 0.0532 & 0.069 & 130 \\
\hline PCB 187 & 8.82 & 3.86 & 10.4 & 14.8 & 9.48 & 9.47 & 3.9 & 41 \\
\hline PCB 188 & 0.0346 & 0.0264 & 0.0500 & 0.0687 & 0.0388 & 0.0437 & 0.016 & 38 \\
\hline PCB 189 & 0.133 & 0.0820 & 0.0143 & 0.203 & 0.169 & 0.120 & 0.074 & 62 \\
\hline PCB 191 & 0.144 & 0.0680 & 0.147 & 0.195 & 0.165 & 0.144 & 0.047 & 33 \\
\hline PCB 194 & 1.24 & 0.536 & 1.46 & 2.13 & 1.15 & 1.31 & 0.58 & 44 \\
\hline PCB 195 & 0.295 & 0.183 & 0.303 & 0.311 & 0.293 & 0.277 & 0.053 & 19 \\
\hline PCB 196 & 2.12 & 0.928 & 2.07 & 3.29 & 1.96 & 2.07 & 0.84 & 40 \\
\hline PCB 197 & 0.170 & 0.0748 & 0.164 & 0.242 & 0.151 & 0.160 & 0.060 & 37 \\
\hline PCB 199 & 6.11 & 2.26 & 7.24 & 12.4 & 5.70 & 6.74 & 3.7 & 54 \\
\hline PCB 200 & $<\mathrm{LOQ}$ & $<\mathrm{LOQ}$ & $<\mathrm{LOQ}$ & $<$ LOQ & $<\mathrm{LOQ}$ & $<\mathrm{LOQ}$ & & \\
\hline PCB 201 & 1.34 & 0.537 & 1.92 & 3.50 & 1.31 & 1.72 & 1.1 & 64 \\
\hline PCB 202 & 0.481 & 0.238 & 0.721 & 1.34 & 0.510 & 0.658 & 0.42 & 64 \\
\hline PCB 205 & 0.0622 & 0.0319 & 0.0689 & 0.0737 & 0.0547 & 0.0583 & 0.016 & 28 \\
\hline PCB 206 & 0.443 & $<\mathrm{LOQ}$ & 0.435 & 0.747 & 0.371 & 0.499 & 0.17 & 34 \\
\hline PCB 207 & 0.168 & 0.0822 & 0.171 & 0.309 & 0.149 & 0.176 & 0.083 & 47 \\
\hline PCB 208 & 0.222 & 0.0952 & 0.232 & 0.474 & 0.197 & 0.244 & 0.14 & 57 \\
\hline PCB 209 & 0.264 & 0.0797 & 0.284 & 0.615 & 0.180 & 0.285 & 0.20 & 71 \\
\hline
\end{tabular}


Appendix 46. Brominated diphenyl ether (BDE) and polychlorinated biphenyl (PCB) mass fractions (ng g ${ }^{-1}$ wet mass) in glaucous gull eggs collected at the Sinuk River delta, Alaska in 2008 (compounds shown in red and blue were above and below reference value ranges, respectively).

\begin{tabular}{|c|c|c|c|c|c|c|c|c|c|c|c|}
\hline Compound & 1339 & 1340 & $1340-2$ & 1340 Mean & $\%$ difference & 1343 & 1344 & 1345 & Mean & SD & RSD \\
\hline BDE47 & 1.74 & 1.83 & 1.81 & 1.82 & 0.98 & 2.06 & 2.18 & 0.997 & 1.76 & 0.46 & 26 \\
\hline BDE99 & 0.941 & 1.60 & 1.64 & 1.62 & -2.3 & 1.02 & 1.28 & 1.02 & 1.18 & 0.28 & 24 \\
\hline BDE100 & 0.731 & 0.955 & 0.937 & 0.946 & 1.9 & 0.913 & 1.14 & 0.660 & 0.877 & 0.19 & 21 \\
\hline PCB 8 & $<\mathrm{LOD}$ & $<\mathrm{LOD}$ & $<\mathrm{LOD}$ & $<$ LOD & & $<\mathrm{LOD}$ & $<\mathrm{LOD}$ & $<\mathrm{LOD}$ & $<$ LOD & & \\
\hline PCB 18 & $<\mathrm{LOD}$ & $<\mathrm{LOD}$ & $<\mathrm{LOD}$ & $<$ LOD & & $<\mathrm{LOD}$ & $<\mathrm{LOD}$ & $<\mathrm{LOD}$ & $<$ LOD & & \\
\hline PCB $28+31$ & 3.82 & 3.38 & 3.22 & 3.30 & 4.8 & 3.59 & 4.35 & 2.81 & 3.57 & 0.58 & 16 \\
\hline PCB 29 & $<\mathrm{LOQ}$ & $<$ LOQ & $<\mathrm{LOQ}$ & $<$ LOQ & & $<\mathrm{LOQ}$ & $<$ LOQ & $<\mathrm{LOQ}$ & $<$ LOQ & & \\
\hline PCB 44 & 0.0695 & 0.140 & 0.142 & 0.141 & -1.4 & 0.0830 & 0.171 & 0.165 & 0.126 & 0.047 & 37 \\
\hline PCB 45 & $<\mathrm{LOQ}$ & $<\mathrm{LOQ}$ & $<\mathrm{LOQ}$ & $<$ LOQ & & $<\mathrm{LOQ}$ & $<\mathrm{LOQ}$ & $<\mathrm{LOQ}$ & $<$ LOQ & & \\
\hline PCB 49 & 0.202 & 0.545 & 0.527 & 0.536 & 3.3 & 0.168 & 0.697 & 0.264 & 0.373 & 0.23 & 62 \\
\hline PCB 52 & 1.29 & 2.71 & 2.59 & 2.65 & 4.5 & 1.86 & 3.48 & 2.41 & 2.34 & 0.82 & 35 \\
\hline PCB 56 & $<$ LOQ & $<\mathrm{LOQ}$ & $<$ LOQ & $<$ LOQ & & $<\mathrm{LOQ}$ & 0.0284 & 0.0258 & $<\mathbf{L O Q}$ & & \\
\hline PCB 63 & $<\mathrm{LOQ}$ & $<\mathrm{LOQ}$ & $<\mathrm{LOQ}$ & $<$ LOQ & & $<\mathrm{LOQ}$ & $<\mathrm{LOQ}$ & $<\mathrm{LOQ}$ & $<\mathbf{L O Q}$ & & \\
\hline PCB 66 & 5.36 & 4.01 & 3.80 & 3.91 & 5.4 & 3.49 & 5.58 & 3.80 & 4.43 & 0.97 & 22 \\
\hline PCB 70 & 0.196 & 0.760 & 0.753 & 0.756 & 0.89 & 0.419 & 0.378 & 0.184 & 0.387 & 0.23 & 60 \\
\hline PCB 74 & 0.381 & 3.51 & 3.29 & 3.40 & 6.5 & 3.36 & 4.77 & 3.19 & 3.02 & 1.6 & 53 \\
\hline PCB 79 & $<\mathrm{LOQ}$ & $<$ LOQ & $<$ LOQ & $<$ LOQ & & $<$ LOQ & $<$ LOQ & $<\mathrm{LOQ}$ & $<$ LOQ & & \\
\hline PCB 82 & 0.0847 & 0.289 & 0.288 & 0.288 & 0.14 & 0.0140 & 0.145 & 0.0848 & 0.123 & 0.10 & 84 \\
\hline PCB 87 & 0.739 & 0.814 & 0.846 & 0.830 & -3.8 & 0.522 & 1.28 & 0.566 & 0.787 & 0.30 & 38 \\
\hline PCB 92 & 0.386 & 0.903 & 0.864 & 0.884 & 4.4 & 0.739 & 1.14 & 0.884 & 0.806 & 0.28 & 34 \\
\hline PCB 95+121 & 0.230 & 0.567 & 0.578 & 0.572 & -1.9 & 0.197 & 0.729 & 0.530 & 0.452 & 0.23 & 51 \\
\hline PCB 99 & 19.7 & 12.7 & 12.4 & 12.6 & 2.4 & 14.7 & 19.9 & 11.7 & 15.7 & 3.9 & 25 \\
\hline PCB 101 & 4.81 & 4.76 & 4.53 & 4.64 & 4.8 & 2.46 & 6.28 & 2.59 & 4.16 & 1.6 & 39 \\
\hline PCB 105 & 6.98 & 3.99 & 3.72 & 3.86 & 7.0 & 4.10 & 6.45 & 4.13 & 5.10 & 1.5 & 29 \\
\hline PCB 106 & 0.107 & $<\mathrm{LOQ}$ & $<\mathrm{LOQ}$ & $<$ LOQ & & 0.104 & 0.0430 & $<\mathrm{LOQ}$ & $<$ LOQ & & \\
\hline PCB 107 & 0.307 & 0.515 & 0.506 & 0.510 & 1.9 & 0.520 & 0.365 & 0.279 & 0.396 & 0.11 & 29 \\
\hline PCB 110 & 4.87 & 3.92 & 3.80 & 3.86 & 3.4 & 2.64 & 3.97 & 2.56 & 3.58 & 0.98 & 27 \\
\hline PCB 112 & $<\mathrm{LOD}$ & $<\mathrm{LOD}$ & $<\mathrm{LOD}$ & $<$ LOD & & $<\mathrm{LOD}$ & $<\mathrm{LOD}$ & $<\mathrm{LOD}$ & $<$ LOD & & \\
\hline PCB 114 & 0.596 & 0.379 & 0.383 & 0.381 & -0.99 & 0.376 & 0.628 & 0.372 & 0.471 & 0.13 & 28 \\
\hline PCB 118 & 25.2 & 15.5 & 14.8 & 15.1 & 5.0 & 16.7 & 25.5 & 14.5 & 19.4 & 5.5 & 28 \\
\hline PCB 119 & 0.503 & 0.319 & 0.317 & 0.318 & 0.68 & 0.370 & 0.478 & 0.328 & 0.399 & 0.086 & 22 \\
\hline PCB 127 & $<\mathrm{LOD}$ & $<\mathrm{LOD}$ & $<\mathrm{LOD}$ & $<$ LOD & & $<\mathrm{LOD}$ & $<\mathrm{LOD}$ & $<\mathrm{LOD}$ & $<$ LOD & & \\
\hline PCB 128 & 4.36 & 2.73 & 2.61 & 2.67 & 4.6 & 2.93 & 4.61 & 2.41 & 3.40 & 1.0 & 30 \\
\hline PCB 130 & 1.40 & 0.817 & 0.791 & 0.804 & 3.2 & 0.848 & 1.62 & 0.892 & 1.11 & 0.37 & 34 \\
\hline PCB 137 & 2.01 & 1.13 & 1.12 & 1.12 & 0.25 & 1.24 & 2.12 & 1.05 & 1.51 & 0.51 & 34 \\
\hline PCB 138 & 30.5 & 18.4 & 17.5 & 17.9 & 4.9 & 21.8 & 33.2 & 16.1 & 23.9 & 7.6 & 32 \\
\hline PCB 146 & 7.18 & 4.27 & 4.09 & 4.18 & 4.4 & 5.60 & 8.92 & 4.27 & 6.03 & 2.0 & 34 \\
\hline PCB 149 & 3.64 & 3.68 & 3.55 & 3.61 & 3.5 & 2.04 & 3.36 & 1.99 & 2.93 & 0.84 & 29 \\
\hline
\end{tabular}


Appendix 46 (Continued).

\begin{tabular}{|c|c|c|c|c|c|c|c|c|c|c|c|}
\hline Compound & 1339 & 1340 & 1340-2 & 1340 Mean & $\%$ difference & 1343 & 1344 & 1345 & Mean & SD & RSD \\
\hline PCB 151 & 0.327 & 0.584 & 0.585 & 0.584 & -0.17 & 0.300 & 0.571 & 0.423 & 0.441 & 0.13 & 30 \\
\hline PCB $153+132$ & 55.2 & 33.7 & 32.1 & 32.9 & 4.9 & 51.3 & 69.3 & 29.4 & 47.6 & 17 & 35 \\
\hline РCB 154 & 0.732 & 0.498 & 0.493 & 0.496 & 1.1 & 0.551 & 0.864 & 0.479 & 0.624 & 0.17 & 27 \\
\hline РCB 156 & 1.80 & 1.10 & 1.07 & 1.09 & 3.0 & 1.32 & 2.00 & 0.949 & 1.43 & 0.45 & 32 \\
\hline PCB 157 & 0.540 & 0.333 & 0.324 & 0.328 & 3.0 & 0.366 & 0.545 & 0.277 & 0.411 & 0.12 & 30 \\
\hline PCB 158 & 1.89 & 1.18 & 1.19 & 1.18 & -1.5 & 1.42 & 2.11 & 1.01 & 1.52 & 0.47 & 31 \\
\hline PCB 159 & $<\mathrm{LOQ}$ & $<\mathrm{LOQ}$ & $<\mathrm{LOQ}$ & $<\mathbf{L O Q}$ & & $<\mathrm{LOQ}$ & $<\mathrm{LOQ}$ & $<\mathrm{LOQ}$ & $<$ LOQ & & \\
\hline PCB 163 & 6.70 & 4.00 & 3.88 & 3.94 & 3.0 & 5.10 & 7.23 & 3.57 & 5.31 & 1.6 & 31 \\
\hline PCB 165 & 0.0357 & 0.0360 & 0.0358 & 0.0359 & 0.70 & 0.0449 & 0.0676 & 0.0382 & 0.0445 & 0.013 & 30 \\
\hline PCB 166 & 0.113 & 0.0833 & 0.0800 & 0.0817 & 4.0 & 0.0783 & 0.126 & 0.0654 & 0.0929 & 0.026 & 28 \\
\hline PCB 167 & 1.21 & 0.749 & 0.723 & 0.736 & 3.5 & 0.877 & 1.61 & 0.771 & 1.04 & 0.37 & 36 \\
\hline PCB 170 & 3.91 & 2.43 & 2.34 & 2.38 & 3.8 & 3.65 & 5.51 & 2.07 & 3.50 & 1.4 & 39 \\
\hline PCB 172 & 0.810 & 0.470 & 0.451 & 0.461 & 4.0 & 0.693 & 1.16 & 0.436 & 0.712 & 0.30 & 42 \\
\hline PCB 174 & 0.473 & 0.382 & 0.369 & 0.376 & 3.6 & 0.230 & 0.430 & 0.207 & 0.343 & 0.12 & 35 \\
\hline PCB 175 & 0.290 & 0.162 & 0.171 & 0.167 & -5.6 & 0.183 & 0.388 & 0.168 & 0.239 & 0.098 & 41 \\
\hline PCB 176 & 0.0348 & 0.0262 & 0.0300 & 0.0281 & -14 & 0.0333 & 0.0365 & $<\mathrm{LOQ}$ & 0.0332 & 0.0036 & 11 \\
\hline PCB 177 & 0.851 & 0.666 & 0.650 & 0.658 & 2.4 & 0.554 & 1.00 & 0.500 & 0.713 & 0.21 & 29 \\
\hline РCB 178 & 0.850 & 0.547 & 0.531 & 0.539 & 3.1 & 0.910 & 1.18 & 0.617 & 0.819 & 0.25 & 31 \\
\hline PCB $180+193$ & 11.0 & 6.95 & 6.60 & 6.78 & 5.3 & 9.82 & 16.7 & 5.77 & 10.0 & 4.3 & 43 \\
\hline PCB 183 & 3.90 & 2.33 & 2.25 & 2.29 & 3.4 & 3.38 & 5.92 & 2.20 & 3.54 & 1.5 & 43 \\
\hline PCB 185 & 0.0691 & 0.0610 & 0.0586 & 0.0598 & 4.1 & 0.0360 & 0.0604 & 0.0509 & 0.0553 & 0.013 & 23 \\
\hline PCB 187 & 8.01 & 4.58 & 4.27 & 4.42 & 6.9 & 5.30 & 10.4 & 4.26 & 6.48 & 2.7 & 41 \\
\hline PCB 188 & 0.0175 & 0.0201 & 0.0201 & 0.0201 & 0.41 & 0.0158 & 0.0207 & 0.0128 & 0.0174 & 0.0032 & 19 \\
\hline PCB 189 & 0.147 & 0.0955 & 0.0947 & 0.0951 & 0.87 & 0.133 & 0.229 & 0.0451 & 0.130 & 0.068 & 52 \\
\hline PCB 191 & 0.127 & 0.0824 & 0.0822 & 0.0823 & 0.33 & 0.103 & 0.195 & 0.0756 & 0.116 & 0.048 & 41 \\
\hline РCB 194 & 0.813 & 0.478 & 0.477 & 0.477 & 0.17 & 1.09 & 1.53 & 0.500 & 0.883 & 0.44 & 50 \\
\hline PCB 195 & 0.278 & 0.226 & 0.222 & 0.224 & 1.9 & 0.311 & 0.418 & 0.180 & 0.282 & 0.091 & 32 \\
\hline PCB 196 & 1.40 & 1.18 & 1.14 & 1.16 & 3.5 & 1.51 & 2.24 & 1.03 & 1.47 & 0.47 & 32 \\
\hline PCB 197 & 0.107 & 0.111 & 0.110 & 0.110 & 0.79 & 0.0938 & 0.191 & 0.0764 & 0.116 & 0.044 & 38 \\
\hline PCB 199 & 4.30 & 3.22 & 3.21 & 3.21 & 0.47 & 4.06 & 6.50 & 2.66 & 4.15 & 1.5 & 35 \\
\hline PCB 200 & $<\mathrm{LOD}$ & $<$ LOD & $<\mathrm{LOD}$ & $<$ LOD & & $<$ LOD & $<\mathrm{LOD}$ & $<\mathrm{LOD}$ & $<$ LOD & & \\
\hline PCB 201 & 1.20 & 0.777 & 0.794 & 0.785 & -2.1 & 0.704 & 1.08 & 0.589 & 0.873 & 0.26 & 30 \\
\hline PCB 202 & 0.293 & 0.266 & 0.272 & 0.269 & -2.0 & 0.408 & 0.378 & 0.201 & 0.310 & 0.084 & 27 \\
\hline PCB 205 & 0.0403 & 0.0369 & 0.0356 & 0.0362 & 3.6 & 0.0405 & 0.0409 & 0.0465 & 0.0409 & 0.0037 & 9.0 \\
\hline PCB 206 & 0.201 & 0.310 & 0.323 & 0.316 & -4.0 & 0.366 & 0.314 & 0.232 & 0.286 & 0.068 & 24 \\
\hline PCB 207 & 0.0961 & 0.0937 & 0.0965 & 0.0951 & -3.0 & 0.0930 & 0.134 & 0.0582 & 0.0952 & 0.027 & 28 \\
\hline PCB 208 & 0.0800 & 0.0949 & 0.0955 & 0.0952 & -0.62 & 0.110 & 0.109 & 0.0287 & 0.0844 & 0.033 & 40 \\
\hline РCB 209 & 0.190 & 0.192 & 0.202 & 0.197 & -5.0 & 0.127 & 0.172 & 0.112 & 0.160 & 0.038 & 24 \\
\hline
\end{tabular}


Appendix 47. Brominated diphenyl ether (BDE) and polychlorinated biphenyl (PCB) mass fractions ( $\mathrm{ng} \mathrm{g}^{-1}$ wet mass) in glaucous gull eggs collected at Safety Sound, Alaska in 2008 (compounds shown in red and blue were above and below reference value ranges, respectively). Egg 1367 is believed to be a common eider.

\begin{tabular}{|c|c|c|c|c|c|c|c|c|}
\hline Compound & 1365 & 1367 & 1368 & 1369 & 1370 & Mean & SD & RSD \\
\hline BDE47 & 1.22 & 2.62 & 1.54 & 1.17 & 1.68 & 1.65 & 0.58 & 36 \\
\hline BDE99 & 1.11 & 1.10 & 0.987 & 1.06 & 1.07 & 1.06 & 0.047 & 4.4 \\
\hline BDE100 & 0.725 & 0.993 & 0.722 & 0.838 & 0.794 & 0.814 & 0.11 & 14 \\
\hline PCB 8 & $<\mathrm{LOD}$ & $<\mathrm{LOD}$ & 0.0189 & $<\mathrm{LOD}$ & 0.0537 & 0.0363 & 0.025 & 68 \\
\hline PCB 18 & $<\mathrm{LOD}$ & $<\mathrm{LOD}$ & $<\mathrm{LOD}$ & $<\mathrm{LOD}$ & $<\mathrm{LOD}$ & $<$ LOD & & \\
\hline PCB $28+31$ & 2.38 & 4.12 & 3.77 & 2.65 & 2.92 & 3.17 & 0.75 & 24 \\
\hline РCB 29 & $<\mathrm{LOQ}$ & $<\mathrm{LOQ}$ & $<\mathrm{LOQ}$ & $<\mathrm{LOQ}$ & $<\mathrm{LOQ}$ & $<$ LOQ & & \\
\hline РCB 44 & 0.146 & 0.0637 & 0.103 & 0.0453 & 0.124 & 0.0963 & 0.042 & 43 \\
\hline PCB 45 & $<\mathrm{LOQ}$ & $<\mathrm{LOQ}$ & $<\mathrm{LOQ}$ & $<\mathrm{LOQ}$ & $<\mathrm{LOQ}$ & $<$ LOQ & & \\
\hline PCB 49 & 0.257 & 0.0553 & 0.269 & 0.0915 & 0.146 & 0.164 & 0.096 & 59 \\
\hline PCB 52 & 1.89 & 0.652 & 3.36 & 0.765 & 2.28 & 1.79 & 1.1 & 63 \\
\hline PCB 56 & $<\mathrm{LOQ}$ & $<\mathrm{LOQ}$ & $<\mathrm{LOQ}$ & 0.0256 & $<\mathrm{LOQ}$ & $<$ LOQ & & \\
\hline PCB 63 & $<\mathrm{LOQ}$ & $<\mathrm{LOQ}$ & 0.198 & $<\mathrm{LOQ}$ & $<\mathrm{LOQ}$ & $<\mathrm{LOQ}$ & & \\
\hline PCB 66 & 2.54 & 7.66 & 4.87 & 3.69 & 4.49 & 4.65 & 1.9 & 41 \\
\hline PCB 70 & 0.0943 & 0.0462 & 0.263 & 0.0397 & 0.207 & 0.130 & 0.10 & 77 \\
\hline PCB 74 & 2.30 & 6.91 & 4.26 & 3.27 & 3.80 & 4.11 & 1.7 & 42 \\
\hline РCB 79 & $<\mathrm{LOQ}$ & $<\mathrm{LOQ}$ & $<\mathrm{LOQ}$ & $<\mathrm{LOQ}$ & $<\mathrm{LOQ}$ & $<$ LOQ & & \\
\hline PCB 82 & 0.0397 & 0.0239 & 0.0277 & 0.00762 & 0.247 & 0.0692 & 0.10 & 150 \\
\hline PCB 87 & 0.437 & 0.938 & 0.601 & 0.289 & 0.504 & 0.554 & 0.24 & 44 \\
\hline PCB 92 & 0.857 & 0.410 & 1.13 & 0.381 & 0.922 & 0.740 & 0.33 & 45 \\
\hline PCB 95+121 & 0.283 & 0.249 & 0.372 & $<\mathrm{LOD}$ & 0.441 & 0.336 & 0.087 & 26 \\
\hline РCB 99 & 10.1 & 33.0 & 15.2 & 11.9 & 15.1 & 17.1 & 9.2 & 54 \\
\hline PCB 101 & 2.81 & 0.431 & 3.74 & 0.394 & 2.20 & 1.92 & 1.5 & 77 \\
\hline PCB 105 & 2.33 & 9.05 & 4.63 & 2.94 & 4.64 & 4.72 & 2.6 & 56 \\
\hline PCB 106 & 0.0248 & 0.0231 & 0.235 & 0.0431 & 0.0603 & 0.0773 & 0.090 & 120 \\
\hline РCB 107 & 0.141 & 0.110 & 0.479 & 0.175 & 0.307 & 0.243 & 0.15 & 63 \\
\hline PCB 110 & 2.16 & 1.76 & 3.23 & 0.845 & 3.38 & 2.27 & 1.1 & 46 \\
\hline PCB 112 & $<\mathrm{LOD}$ & $<\mathrm{LOD}$ & $<\mathrm{LOD}$ & $<\mathrm{LOD}$ & $<\mathrm{LOD}$ & $<$ LOD & & \\
\hline PCB 114 & 0.253 & 0.843 & 0.428 & 0.267 & 0.423 & 0.443 & 0.24 & 54 \\
\hline PCB 118 & 10.2 & 36.1 & 18.0 & 12.9 & 17.8 & 19.0 & 10 & 53 \\
\hline РCB 119 & 0.261 & 0.838 & 0.396 & 0.292 & 0.388 & 0.435 & 0.23 & 53 \\
\hline РCB 127 & $<\mathrm{LOD}$ & $<\mathrm{LOD}$ & $<\mathrm{LOD}$ & $<\mathrm{LOD}$ & $<\mathrm{LOD}$ & $<$ LOD & & \\
\hline PCB 128 & 1.80 & 6.61 & 3.01 & 2.36 & 3.18 & 3.39 & 1.9 & 55 \\
\hline PCB 130 & 0.411 & 1.62 & 0.862 & 0.794 & 0.971 & 0.932 & 0.44 & 47 \\
\hline PCB 137 & 0.753 & 2.90 & 1.40 & 1.17 & 1.48 & 1.54 & 0.81 & 53 \\
\hline PCB 138 & 12.7 & 50.3 & 20.4 & 17.3 & 22.4 & 24.6 & 15 & 60 \\
\hline PCB 146 & 3.31 & 12.8 & 5.03 & 4.72 & 5.40 & 6.26 & 3.8 & 60 \\
\hline PCB 149 & 1.50 & 2.53 & 2.51 & 1.37 & 2.94 & 2.17 & 0.70 & 32 \\
\hline
\end{tabular}


Appendix 47 (Continued).

\begin{tabular}{|c|c|c|c|c|c|c|c|c|}
\hline Compound & 1365 & 1367 & 1368 & 1369 & 1370 & Mean & SD & RSD \\
\hline PCB 151 & 0.400 & 0.262 & 0.448 & 0.180 & 0.581 & 0.374 & 0.16 & 42 \\
\hline PCB $153+132$ & 25.8 & 104 & 39.2 & 37.1 & 39.9 & 49.3 & 31 & 64 \\
\hline PCB 154 & 0.414 & 1.31 & 0.572 & 0.504 & 0.624 & 0.685 & 0.36 & 52 \\
\hline PCB 156 & 0.758 & 2.89 & 1.33 & 0.986 & 1.36 & 1.46 & 0.83 & 57 \\
\hline PCB 157 & 0.215 & 0.764 & 0.400 & 0.307 & 0.403 & 0.418 & 0.21 & 50 \\
\hline PCB 158 & 0.942 & 4.05 & 1.70 & 1.31 & 1.31 & 1.86 & 1.3 & 67 \\
\hline PCB 159 & $<$ LOQ & $<\mathrm{LOQ}$ & $<\mathrm{LOQ}$ & $<\mathrm{LOQ}$ & $<\mathrm{LOQ}$ & $<\mathbf{L O Q}$ & & \\
\hline PCB 163 & 3.11 & 10.5 & 4.54 & 4.31 & 4.95 & 5.49 & 2.9 & 53 \\
\hline PCB 165 & 0.0315 & 0.104 & 0.0542 & 0.0557 & 0.0418 & 0.0575 & 0.028 & 48 \\
\hline PCB 166 & 0.0733 & 0.177 & 0.0862 & 0.0903 & 0.0999 & 0.105 & 0.041 & 39 \\
\hline PCB 167 & 0.413 & 2.14 & 0.927 & 0.669 & 0.886 & 1.01 & 0.67 & 66 \\
\hline PCB 170 & 1.71 & 8.60 & 2.97 & 2.63 & 2.75 & 3.73 & 2.8 & 74 \\
\hline PCB 172 & 0.336 & 1.58 & 0.538 & 0.537 & 0.602 & 0.719 & 0.49 & 69 \\
\hline PCB 174 & 0.154 & 0.308 & 0.200 & 0.149 & 0.304 & 0.223 & 0.078 & 35 \\
\hline PCB 175 & 0.0814 & 0.509 & 0.247 & 0.199 & 0.182 & 0.244 & 0.16 & 66 \\
\hline PCB 176 & 0.0161 & $<$ LOQ & 0.0421 & $<\mathrm{LOQ}$ & 0.0296 & 0.0292 & 0.013 & 44 \\
\hline PCB 177 & 0.278 & 1.16 & 0.470 & 0.507 & 0.576 & 0.599 & 0.33 & 56 \\
\hline PCB 178 & 0.409 & 1.80 & 0.635 & 0.631 & 0.553 & 0.806 & 0.56 & 70 \\
\hline PCB $180+193$ & 4.89 & 23.0 & 8.24 & 7.32 & 7.68 & 10.2 & 7.2 & 71 \\
\hline PCB 183 & 1.70 & 8.29 & 2.80 & 2.67 & 2.72 & 3.64 & 2.6 & 73 \\
\hline PCB 185 & 0.0519 & 0.0316 & 0.0440 & $<$ LOQ & 0.0139 & 0.0354 & 0.017 & 47 \\
\hline PCB 187 & 2.56 & 15.1 & 4.53 & 4.51 & 4.97 & 6.33 & 5.0 & 79 \\
\hline PCB 188 & 0.0119 & 0.0596 & 0.0122 & 0.0198 & 0.0202 & 0.0248 & 0.020 & 80 \\
\hline PCB 189 & 0.0749 & 0.281 & 0.141 & 0.111 & 0.0990 & 0.141 & 0.082 & 58 \\
\hline PCB 191 & 0.0808 & 0.277 & 0.114 & 0.138 & 0.111 & 0.144 & 0.077 & 53 \\
\hline PCB 194 & 0.398 & 2.35 & 0.768 & 0.612 & 0.544 & 0.934 & 0.80 & 86 \\
\hline PCB 195 & 0.168 & 0.764 & 0.241 & 0.259 & 0.223 & 0.331 & 0.24 & 74 \\
\hline РCB 196 & 1.01 & 3.22 & 1.31 & 1.14 & 1.19 & 1.57 & 0.92 & 59 \\
\hline PCB 197 & 0.0968 & 0.258 & 0.141 & 0.0804 & 0.116 & 0.138 & 0.070 & 51 \\
\hline PCB 199 & 2.27 & 9.94 & 3.35 & 3.26 & 3.26 & 4.41 & 3.1 & 71 \\
\hline PCB 200 & $<\mathrm{LOD}$ & $<\mathrm{LOD}$ & $<\mathrm{LOD}$ & $<\mathrm{LOD}$ & $<\mathrm{LOD}$ & $<$ LOD & & \\
\hline PCB 201 & 0.472 & 1.94 & 0.945 & 1.23 & 0.728 & 1.06 & 0.56 & 53 \\
\hline PCB 202 & 0.213 & 0.567 & 0.224 & 0.284 & 0.193 & 0.296 & 0.16 & 52 \\
\hline PCB 205 & 0.0434 & 0.123 & 0.0892 & 0.117 & 0.0868 & 0.0919 & 0.032 & 34 \\
\hline PCB 206 & 0.183 & 0.721 & 0.277 & 0.374 & 0.195 & 0.350 & 0.22 & 63 \\
\hline PCB 207 & 0.0495 & 0.234 & 0.0969 & 0.0922 & 0.101 & 0.115 & 0.070 & 61 \\
\hline PCB 208 & 0.0790 & 0.233 & 0.0605 & 0.0867 & 0.0521 & 0.102 & 0.074 & 73 \\
\hline РCB 209 & 0.0987 & 0.173 & 0.188 & 0.115 & 0.118 & 0.138 & 0.039 & 28 \\
\hline
\end{tabular}


Appendix 48. Brominated diphenyl ether (BDE) and polychlorinated biphenyl (PCB) mass fractions ( $\mathrm{ng} \mathrm{g}^{-1}$ wet mass) in glaucous gull eggs collected at Bluff, Alaska in 2008 (compounds shown in red and blue were above and below reference value ranges, respectively).

\begin{tabular}{|c|c|c|c|c|c|c|c|}
\hline Compound & 1384 & 1385 & 1388 & 1389 & Mean & SD & RSD \\
\hline BDE47 & 1.29 & 4.92 & 6.17 & 7.03 & 4.85 & 2.5 & 52 \\
\hline BDE99 & 1.01 & 4.62 & 6.82 & 7.35 & 4.95 & 2.9 & 58 \\
\hline BDE100 & 0.811 & 1.39 & 1.92 & 2.21 & 1.58 & 0.62 & 39 \\
\hline PCB 8 & $<\mathrm{LOD}$ & $<\mathrm{LOD}$ & $<\mathrm{LOD}$ & $<\mathrm{LOD}$ & $<$ LOD & & \\
\hline PCB 18 & $<\mathrm{LOD}$ & $<\mathrm{LOD}$ & $<$ LOD & $<$ LOD & $<$ LOD & & \\
\hline PCB $28+31$ & 3.79 & 2.85 & 3.77 & 3.32 & 3.43 & 0.45 & 13 \\
\hline PCB 29 & $<\mathrm{LOQ}$ & $<\mathrm{LOQ}$ & $<\mathrm{LOQ}$ & $<\mathrm{LOQ}$ & $<$ LOQ & & \\
\hline PCB 44 & 0.199 & 0.0605 & $<\mathrm{LOQ}$ & 0.116 & 0.125 & 0.070 & 56 \\
\hline PCB 45 & $<\mathrm{LOQ}$ & $<\mathrm{LOQ}$ & $<\mathrm{LOQ}$ & $<\mathrm{LOQ}$ & $<$ LOQ & & \\
\hline РCB 49 & 0.171 & 0.0656 & 0.0866 & 0.531 & 0.214 & 0.22 & 100 \\
\hline РCB 52 & 2.94 & 0.546 & 0.668 & 2.45 & 1.65 & 1.2 & 74 \\
\hline РСB 56 & $<\mathrm{LOQ}$ & $<$ LOQ & $<\mathrm{LOQ}$ & $<$ LOQ & $<$ LOQ & & \\
\hline PCB 63 & $<\mathrm{LOQ}$ & $<\mathrm{LOQ}$ & 0.203 & $<\mathrm{LOQ}$ & $<$ LOQ & & \\
\hline PCB 66 & 3.74 & 3.50 & 4.22 & 4.31 & 3.94 & 0.39 & 9.8 \\
\hline PCB 70 & 0.583 & 0.0595 & 0.109 & 0.167 & 0.230 & 0.24 & 100 \\
\hline PCB 74 & 3.43 & 3.11 & 3.74 & 3.88 & 3.54 & 0.34 & 9.6 \\
\hline РCB 79 & $<\mathrm{LOQ}$ & $<\mathrm{LOQ}$ & $<\mathrm{LOQ}$ & $<\mathrm{LOQ}$ & $<\mathrm{LOQ}$ & & \\
\hline PCB 82 & 0.190 & 0.0528 & 0.0496 & 0.0737 & 0.0916 & 0.067 & 73 \\
\hline PCB 87 & 0.533 & 0.286 & 0.401 & 0.716 & 0.484 & 0.18 & 38 \\
\hline РCВ 92 & 1.19 & 0.332 & 0.448 & 0.759 & 0.681 & 0.38 & 56 \\
\hline РCB 95+121 & 0.915 & 0.0425 & 0.0652 & 0.400 & 0.356 & 0.41 & 110 \\
\hline РCB 99 & 14.7 & 10.2 & 13.4 & 17.3 & 13.9 & 2.9 & 21 \\
\hline РCB 101 & 2.72 & 0.188 & 0.214 & 4.42 & 1.89 & 2.1 & 110 \\
\hline PCB 105 & 4.36 & 3.49 & 4.81 & 5.90 & 4.64 & 1.0 & 22 \\
\hline PCB 106 & 0.0102 & 0.117 & 0.0655 & 0.116 & 0.0772 & 0.051 & 66 \\
\hline PCB 107 & 0.524 & 0.344 & 0.530 & 0.326 & 0.431 & 0.11 & 26 \\
\hline PCB 110 & 3.79 & 1.54 & 2.16 & 3.91 & 2.85 & 1.2 & 42 \\
\hline PCB 112 & $<\mathrm{LOD}$ & $<\mathrm{LOD}$ & $<\mathrm{LOD}$ & $<\mathrm{LOD}$ & $<$ LOD & & \\
\hline PCB 114 & 0.429 & 0.324 & 0.428 & 0.585 & 0.442 & 0.11 & 24 \\
\hline PCB 118 & 17.6 & 12.6 & 16.5 & 21.7 & 17.1 & 3.7 & 22 \\
\hline PCB 119 & 0.373 & 0.282 & 0.380 & 0.404 & 0.360 & 0.054 & 15 \\
\hline PCB 127 & $<\mathrm{LOD}$ & $<\mathrm{LOD}$ & $<\mathrm{LOD}$ & $<$ LOD & $<$ LOD & & \\
\hline РCB 128 & 2.96 & 2.17 & 2.83 & 3.75 & 2.93 & 0.65 & 22 \\
\hline PCB 130 & 0.851 & 0.569 & 0.722 & 1.15 & 0.824 & 0.25 & 30 \\
\hline PCB 137 & 1.26 & 0.946 & 1.21 & 1.60 & 1.26 & 0.27 & 21 \\
\hline PCB 138 & 20.6 & 14.1 & 18.7 & 28.1 & 20.4 & 5.8 & 29 \\
\hline PCB 146 & 5.36 & 3.51 & 4.64 & 8.01 & 5.38 & 1.9 & 36 \\
\hline РCB 149 & 3.28 & 1.63 & 2.00 & 3.37 & 2.57 & 0.88 & 34 \\
\hline
\end{tabular}


Appendix 48 (Continued).

\begin{tabular}{|c|c|c|c|c|c|c|c|}
\hline Compound & 1384 & 1385 & 1388 & 1389 & Mean & SD & RSD \\
\hline PCB 151 & 0.837 & 0.227 & 0.273 & 0.469 & 0.452 & 0.28 & 62 \\
\hline РCB $153+132$ & 43.7 & 27.1 & 36.2 & 58.7 & 41.4 & 13 & 32 \\
\hline PCB 154 & 0.540 & 0.400 & 0.509 & 0.614 & 0.516 & 0.089 & 17 \\
\hline PCB 156 & 1.36 & 0.942 & 1.18 & 1.92 & 1.35 & 0.42 & 31 \\
\hline PCB 157 & 0.367 & 0.284 & 0.342 & 0.521 & 0.378 & 0.10 & 27 \\
\hline PCB 158 & 1.69 & 0.904 & 0.949 & 1.90 & 1.36 & 0.51 & 37 \\
\hline РCB 159 & $<\mathrm{LOQ}$ & $<\mathrm{LOQ}$ & $<\mathrm{LOQ}$ & $<$ LOQ & $<\mathbf{L O Q}$ & & \\
\hline PCB 163 & 4.50 & 3.03 & 3.57 & 6.42 & 4.38 & 1.5 & 34 \\
\hline PCB 165 & 0.0324 & 0.0307 & 0.0399 & 0.0435 & 0.0366 & 0.0061 & 17 \\
\hline PCB 166 & 0.0958 & 0.0814 & 0.0999 & 0.153 & 0.107 & 0.031 & 29 \\
\hline PCB 167 & 0.897 & 0.538 & 0.901 & 1.48 & 0.954 & 0.39 & 41 \\
\hline PCB 170 & 2.98 & 1.85 & 2.55 & 4.64 & 3.01 & 1.2 & 39 \\
\hline PCB 172 & 0.592 & 0.391 & 0.529 & 1.13 & 0.660 & 0.32 & 49 \\
\hline PCB 174 & 0.342 & 0.174 & 0.225 & 0.401 & 0.285 & 0.10 & 37 \\
\hline PCB 175 & 0.180 & 0.147 & 0.166 & 0.319 & 0.203 & 0.079 & 39 \\
\hline PCB 176 & 0.0331 & $<\mathrm{LOQ}$ & 0.0105 & 0.0310 & 0.0249 & 0.012 & 50 \\
\hline PCB 177 & 0.535 & 0.286 & 0.433 & 0.688 & 0.486 & 0.17 & 35 \\
\hline РCB 178 & 0.703 & 0.360 & 0.627 & 0.773 & 0.616 & 0.18 & 29 \\
\hline PCB $180+193$ & 8.56 & 5.52 & 7.39 & 13.0 & 8.61 & 3.2 & 37 \\
\hline PCB 183 & 2.81 & 1.94 & 2.85 & 4.70 & 3.07 & 1.2 & 38 \\
\hline PCB 185 & 0.0141 & $<\mathrm{LOQ}$ & $<$ LOQ & 0.0367 & 0.0254 & 0.016 & 63 \\
\hline PCB 187 & 5.04 & 2.86 & 4.78 & 10.2 & 5.72 & 3.1 & 55 \\
\hline PCB 188 & 0.00794 & 0.00551 & 0.0195 & 0.0299 & 0.0157 & 0.011 & 72 \\
\hline РCB 189 & $<\mathrm{LOQ}$ & 0.103 & $<\mathrm{LOQ}$ & 0.208 & 0.156 & 0.075 & 48 \\
\hline РCB 191 & 0.121 & 0.0779 & 0.0856 & 0.139 & 0.106 & 0.029 & 27 \\
\hline PCB 194 & 0.818 & 0.406 & 0.665 & 1.49 & 0.846 & 0.46 & 55 \\
\hline PCB 195 & 0.235 & 0.163 & 0.197 & 0.348 & 0.236 & 0.080 & 34 \\
\hline PCB 196 & 1.24 & 0.964 & 1.19 & 1.98 & 1.35 & 0.44 & 33 \\
\hline PCB 197 & 0.0852 & 0.0753 & 0.0924 & 0.164 & 0.104 & 0.041 & 39 \\
\hline РCB 199 & 3.47 & 2.41 & 3.13 & 6.75 & 3.94 & 1.9 & 49 \\
\hline PCB 200 & $<\mathrm{LOD}$ & $<\mathrm{LOD}$ & $<\mathrm{LOD}$ & $<\mathrm{LOD}$ & $<$ LOD & & \\
\hline PCB 201 & 0.735 & 0.477 & 0.695 & 1.66 & 0.891 & 0.52 & 59 \\
\hline PCB 202 & 0.299 & 0.188 & 0.205 & 0.229 & 0.230 & 0.049 & 21 \\
\hline PCB 205 & 0.0553 & 0.0155 & 0.0378 & 0.0786 & 0.0468 & 0.027 & 57 \\
\hline PCB 206 & 0.834 & 0.0247 & 0.217 & 0.394 & 0.367 & 0.35 & 94 \\
\hline PCB 207 & 0.0714 & 0.0610 & 0.0804 & 0.148 & 0.0902 & 0.039 & 44 \\
\hline PCB 208 & $<\mathrm{LOQ}$ & 0.0500 & 0.0409 & 0.115 & 0.0685 & 0.040 & 59 \\
\hline РCB 209 & 0.167 & 0.0541 & 0.135 & 0.192 & 0.137 & 0.060 & 44 \\
\hline
\end{tabular}


Appendix 49. Brominated diphenyl ether (BDE) and polychlorinated biphenyl (PCB) mass fractions (ng g ${ }^{-1}$ wet mass) in glaucous gull eggs collected at Carolyn Island, Alaska in 2008 (compounds shown in red and blue were above and below reference value ranges, respectively).

\begin{tabular}{|c|c|c|c|c|c|c|c|c|}
\hline Compound & 1390 & 1393 & 1394 & 1397 & 1398 & Mean & SD & RSD \\
\hline BDE47 & 1.29 & 1.06 & 1.85 & 0.894 & 1.31 & 1.28 & 0.36 & 28 \\
\hline BDE99 & 0.958 & 0.922 & 1.38 & 0.896 & 0.928 & 1.02 & 0.20 & 20 \\
\hline BDE100 & 0.725 & 0.717 & 0.825 & 0.672 & 0.675 & 0.723 & 0.062 & 8.6 \\
\hline PCB 8 & $<\mathrm{LOD}$ & $<\mathrm{LOD}$ & $<$ LOD & $<\mathrm{LOD}$ & $<\mathrm{LOD}$ & $<$ LOD & & \\
\hline PCB 18 & $<$ LOD & $<$ LOD & $<$ LOD & $<$ LOD & $<$ LOD & $<$ LOD & & \\
\hline РCB $28+31$ & 2.68 & 3.74 & 3.65 & 3.70 & 4.11 & 3.57 & 0.53 & 15 \\
\hline РCB 29 & $<$ LOQ & $<\mathrm{LOQ}$ & $<\mathrm{LOQ}$ & $<\mathrm{LOQ}$ & $<\mathrm{LOQ}$ & $<$ LOQ & & \\
\hline РCB 44 & 0.0954 & 0.192 & 0.177 & 0.142 & 0.183 & 0.158 & 0.040 & 25 \\
\hline PCB 45 & $<$ LOQ & $<\mathrm{LOQ}$ & $<$ LOQ & $<$ LOQ & $<\mathrm{LOQ}$ & $<$ LOQ & & \\
\hline PCB 49 & 0.0896 & 0.366 & 0.293 & 0.412 & 0.551 & 0.342 & 0.17 & 50 \\
\hline PCB 52 & 0.626 & 2.74 & 3.96 & 3.75 & 3.78 & 2.97 & 1.4 & 47 \\
\hline PCB 56 & $<$ LOQ & $<\mathrm{LOQ}$ & $<\mathrm{LOQ}$ & $<\mathrm{LOQ}$ & $<\mathrm{LOQ}$ & $<\mathbf{L O Q}$ & & \\
\hline РCB 63 & $<\mathrm{LOQ}$ & $<\mathrm{LOQ}$ & 0.209 & $<\mathrm{LOQ}$ & 0.182 & 0.196 & 0.019 & 9.8 \\
\hline PCB 66 & 4.20 & 4.15 & 4.37 & 3.72 & 5.15 & 4.32 & 0.52 & 12 \\
\hline PCB 70 & 0.101 & 0.256 & 0.376 & 0.395 & 0.335 & 0.292 & 0.12 & 41 \\
\hline PCB 74 & 3.73 & 3.72 & 3.91 & 3.20 & 4.51 & 3.81 & 0.47 & 12 \\
\hline РCB 79 & $<\mathrm{LOQ}$ & $<\mathrm{LOQ}$ & 0.00943 & $<\mathrm{LOQ}$ & $<$ LOQ & $<$ LOQ & & \\
\hline PCB 82 & 0.0120 & 0.0205 & 0.0275 & 0.0703 & 0.0335 & 0.0328 & 0.022 & 69 \\
\hline PCB 87 & 0.408 & 0.721 & 0.637 & 0.805 & 1.15 & 0.743 & 0.27 & 36 \\
\hline РCB 92 & 0.346 & 1.23 & 1.67 & 1.02 & 1.36 & 1.13 & 0.50 & 44 \\
\hline PCB 95+121 & 0.180 & 0.560 & 0.633 & 0.699 & 0.572 & 0.529 & 0.20 & 38 \\
\hline PCB 99 & 15.1 & 14.9 & 14.4 & 11.6 & 16.6 & 14.5 & 1.8 & 13 \\
\hline PCB 101 & 0.258 & 3.65 & 4.04 & 4.84 & 6.05 & 3.77 & 2.2 & 57 \\
\hline PCB 105 & 4.31 & 4.51 & 4.78 & 3.70 & 5.29 & 4.52 & 0.59 & 13 \\
\hline PCB 106 & 0.0828 & 0.0513 & 0.125 & 0.0588 & 0.0103 & 0.0656 & 0.042 & 64 \\
\hline PCB 107 & 0.365 & 0.387 & 0.692 & 0.332 & 0.440 & 0.443 & 0.14 & 33 \\
\hline PCB 110 & 1.60 & 2.99 & 4.41 & 3.27 & 4.15 & 3.28 & 1.1 & 34 \\
\hline PCB 112 & $<\mathrm{LOD}$ & $<\mathrm{LOD}$ & $<\mathrm{LOD}$ & $<\mathrm{LOD}$ & $<$ LOD & $<$ LOD & & \\
\hline PCB 114 & 0.407 & 0.438 & 0.427 & 0.352 & 0.507 & 0.426 & 0.056 & 13 \\
\hline PCB 118 & 17.5 & 17.0 & 17.5 & 13.1 & 19.7 & 17.0 & 2.4 & 14 \\
\hline PCB 119 & 0.399 & 0.370 & 0.353 & 0.288 & 0.424 & 0.367 & 0.052 & 14 \\
\hline PCB 127 & $<\mathrm{LOD}$ & $<\mathrm{LOD}$ & $<\mathrm{LOD}$ & $<\mathrm{LOD}$ & $<\mathrm{LOD}$ & $<$ LOD & & \\
\hline PCB 128 & 3.12 & 2.81 & 3.11 & 2.07 & 3.18 & 2.86 & 0.46 & 16 \\
\hline PCB 130 & 0.881 & 0.873 & 0.679 & 0.579 & 0.875 & 0.778 & 0.14 & 18 \\
\hline PCB 137 & 1.34 & 1.24 & 1.33 & 0.847 & 1.41 & 1.23 & 0.22 & 18 \\
\hline PCB 138 & 22.1 & 20.0 & 20.4 & 13.9 & 22.8 & 19.8 & 3.5 & 18 \\
\hline PCB 146 & 5.85 & 4.96 & 4.72 & 3.53 & 5.70 & 4.95 & 0.93 & 19 \\
\hline PCB 149 & 2.25 & 2.70 & 3.49 & 2.51 & 3.35 & 2.86 & 0.54 & 19 \\
\hline
\end{tabular}


Appendix 49 (Continued).

\begin{tabular}{|c|c|c|c|c|c|c|c|c|}
\hline Compound & 1390 & 1393 & 1394 & 1397 & 1398 & Mean & SD & RSD \\
\hline PCB 151 & 0.256 & 0.592 & 0.810 & 0.546 & 0.720 & 0.585 & 0.21 & 36 \\
\hline PCB $153+132$ & 44.7 & 37.6 & 37.7 & 26.0 & 43.1 & 37.8 & 7.3 & 19 \\
\hline PCB 154 & 0.656 & 0.531 & 0.559 & 0.453 & 0.599 & 0.559 & 0.076 & 14 \\
\hline PCB 156 & 1.30 & 1.16 & 1.39 & 0.925 & 1.42 & 1.24 & 0.20 & 16 \\
\hline PCB 157 & 0.383 & 0.333 & 0.431 & 0.243 & 0.427 & 0.363 & 0.078 & 21 \\
\hline PCB 158 & 1.24 & 1.04 & 1.74 & 0.811 & 1.44 & 1.25 & 0.36 & 29 \\
\hline PCB 159 & $<$ LOQ & $<$ LOQ & $<\mathrm{LOQ}$ & $<\mathrm{LOQ}$ & $<\mathrm{LOQ}$ & $<\mathrm{LOQ}$ & & \\
\hline PCB 163 & 4.77 & 4.18 & 4.29 & 3.16 & 4.89 & 4.26 & 0.69 & 16 \\
\hline PCB 165 & 0.0406 & 0.0315 & 0.0386 & 0.0360 & 0.0324 & 0.0358 & 0.0039 & 11 \\
\hline PCB 166 & 0.103 & 0.0804 & 0.0792 & 0.0648 & 0.0879 & 0.0831 & 0.014 & 17 \\
\hline PCB 167 & 0.914 & 0.795 & 0.797 & 0.529 & 0.948 & 0.796 & 0.16 & 21 \\
\hline PCB 170 & 3.10 & 2.47 & 2.80 & 1.85 & 2.83 & 2.61 & 0.48 & 18 \\
\hline PCB 172 & 0.699 & 0.505 & 0.502 & 0.357 & 0.578 & 0.528 & 0.12 & 24 \\
\hline PCB 174 & 0.248 & 0.268 & 0.313 & 0.233 & 0.335 & 0.279 & 0.043 & 15 \\
\hline PCB 175 & 0.206 & 0.147 & 0.132 & 0.141 & 0.217 & 0.169 & 0.040 & 23 \\
\hline PCB 176 & 0.0140 & 0.0130 & 0.0304 & 0.0216 & 0.0358 & 0.0229 & 0.010 & 44 \\
\hline PCB 177 & 0.636 & 0.556 & 0.481 & 0.336 & 0.598 & 0.521 & 0.12 & 23 \\
\hline PCB 178 & 0.624 & 0.754 & 0.758 & 0.464 & 0.608 & 0.642 & 0.12 & 19 \\
\hline PCB $180+193$ & 8.96 & 7.11 & 7.97 & 4.93 & 8.21 & 7.44 & 1.5 & 21 \\
\hline PCB 183 & 3.21 & 2.60 & 2.70 & 1.66 & 2.98 & 2.63 & 0.59 & 23 \\
\hline PCB 185 & 0.0185 & 0.0281 & 0.0284 & 0.0250 & 0.0392 & 0.0278 & 0.0075 & 27 \\
\hline PCB 187 & 6.42 & 4.94 & 4.65 & 3.03 & 5.51 & 4.91 & 1.2 & 25 \\
\hline PCB 188 & 0.0109 & 0.00976 & 0.0175 & 0.0125 & 0.0185 & 0.0138 & 0.0040 & 29 \\
\hline PCB 189 & 0.162 & 0.107 & 0.114 & 0.0800 & 0.122 & 0.117 & 0.030 & 25 \\
\hline PCB 191 & 0.118 & 0.0821 & 0.103 & 0.0997 & 0.102 & 0.101 & 0.013 & 13 \\
\hline PCB 194 & 0.944 & 0.488 & 0.664 & 0.469 & 0.644 & 0.642 & 0.19 & 30 \\
\hline PCB 195 & 0.316 & 0.161 & 0.197 & 0.166 & 0.243 & 0.216 & 0.065 & 30 \\
\hline PCB 196 & 1.60 & 1.10 & 1.17 & 0.966 & 1.16 & 1.20 & 0.24 & 20 \\
\hline PCB 197 & 0.143 & 0.114 & 0.121 & 0.0580 & 0.113 & 0.110 & 0.032 & 29 \\
\hline РCB 199 & 4.70 & 3.04 & 3.16 & 1.99 & 3.26 & 3.23 & 0.97 & 30 \\
\hline PCB 200 & $<\mathrm{LOD}$ & $<\mathrm{LOD}$ & $<\mathrm{LOD}$ & $<\mathrm{LOD}$ & $<\mathrm{LOD}$ & $<$ LOD & & \\
\hline РCB 201 & 1.08 & 0.848 & 0.913 & 0.454 & 0.760 & 0.810 & 0.23 & 28 \\
\hline PCB 202 & 0.312 & 0.228 & 0.254 & 0.203 & 0.272 & 0.254 & 0.042 & 16 \\
\hline PCB 205 & 0.0439 & 0.0373 & 0.0463 & 0.0437 & 0.0554 & 0.0453 & 0.0065 & 14 \\
\hline PCB 206 & 0.369 & 0.254 & 0.253 & 0.301 & 0.209 & 0.277 & 0.061 & 22 \\
\hline PCB 207 & 0.151 & 0.0751 & 0.0680 & 0.0604 & 0.0961 & 0.0902 & 0.037 & 41 \\
\hline РCB 208 & 0.133 & 0.176 & 0.0782 & 0.0511 & 0.0741 & 0.103 & 0.051 & 50 \\
\hline РCB 209 & 0.199 & 0.0907 & 0.131 & 0.103 & 0.155 & 0.136 & 0.043 & 32 \\
\hline
\end{tabular}


Appendix 50. Brominated diphenyl ether (BDE) and polychlorinated biphenyl (PCB) mass fractions ( $\mathrm{ng} \mathrm{g}^{-1}$ wet mass) in glaucous gull eggs collected at Cape Darby, Alaska in 2008 (compounds shown in red and blue were above and below reference value ranges, respectively).

\begin{tabular}{|c|c|c|c|c|c|c|c|c|}
\hline Compound & 1371 & 1374 & 1377 & 1379 & 1380 & Mean & SD & RSD \\
\hline BDE47 & 1.68 & 1.23 & 1.38 & 0.996 & 0.704 & 1.20 & 0.37 & 31 \\
\hline BDE99 & 0.909 & 0.971 & 1.30 & 0.869 & 0.897 & 0.989 & 0.18 & 18 \\
\hline BDE100 & 0.810 & 0.797 & 0.744 & 0.758 & 0.697 & 0.761 & 0.045 & 5.9 \\
\hline PCB 8 & $<$ LOD & $<$ LOD & 0.00957 & $<$ LOD & $<\mathrm{LOD}$ & $<$ LOD & & \\
\hline PCB 18 & $<$ LOD & $<\mathrm{LOD}$ & $<\mathrm{LOD}$ & $<\mathrm{LOD}$ & $<\mathrm{LOD}$ & $<$ LOD & & \\
\hline РCB 28+31 & 4.33 & 2.64 & 2.74 & 2.73 & 2.23 & 2.93 & 0.81 & 28 \\
\hline РCB 29 & $<$ LOQ & $<\mathrm{LOQ}$ & $<\mathrm{LOQ}$ & $<\mathrm{LOQ}$ & $<\mathrm{LOQ}$ & $<\mathbf{L O Q}$ & & \\
\hline РCB 44 & 0.154 & 0.110 & 0.116 & 0.122 & 0.136 & 0.128 & 0.018 & 14 \\
\hline РCB 45 & $<\mathrm{LOQ}$ & $<\mathrm{LOQ}$ & $<$ LOQ & $<$ LOQ & $<\mathrm{LOQ}$ & $<$ LOQ & & \\
\hline PCB 49 & 0.238 & 0.0984 & 0.290 & 0.194 & 0.227 & 0.210 & 0.071 & 34 \\
\hline PCB 52 & 2.64 & 0.745 & 0.697 & 2.43 & 2.08 & 1.72 & 0.93 & 54 \\
\hline PCB 56 & $<\mathrm{LOQ}$ & $<\mathrm{LOQ}$ & $<\mathrm{LOQ}$ & $<$ LOQ & $<\mathrm{LOQ}$ & $<\mathbf{L O Q}$ & & \\
\hline PCB 63 & 0.364 & $<\mathrm{LOQ}$ & $<\mathrm{LOQ}$ & $<\mathrm{LOQ}$ & $<\mathrm{LOQ}$ & $<\mathbf{L O Q}$ & & \\
\hline PCB 66 & 5.04 & 3.96 & 3.39 & 3.23 & 2.72 & 3.67 & 0.88 & 24 \\
\hline PCB 70 & 1.25 & 0.0978 & 0.197 & 0.0648 & 0.111 & 0.343 & 0.51 & 150 \\
\hline РСB 74 & 5.06 & 3.54 & 3.11 & 2.86 & 2.38 & 3.39 & 1.0 & 30 \\
\hline РСB 79 & $<$ LOQ & $<\mathrm{LOQ}$ & $<\mathrm{LOQ}$ & $<\mathrm{LOQ}$ & $<$ LOQ & $<\mathrm{LOQ}$ & & \\
\hline PCB 82 & 0.0293 & 0.0172 & 0.00894 & 0.0158 & $<\mathrm{LOD}$ & 0.0178 & 0.0085 & 48 \\
\hline РCB 87 & 0.921 & 0.364 & 0.657 & 0.359 & 0.381 & 0.537 & 0.25 & 46 \\
\hline PCB 92 & 0.897 & 0.393 & 0.154 & 0.838 & 0.625 & 0.582 & 0.31 & 53 \\
\hline PCB 95+121 & 0.784 & 0.310 & 0.196 & 0.273 & 0.272 & 0.367 & 0.24 & 65 \\
\hline РCB 99 & 23.9 & 15.2 & 12.4 & 9.41 & 8.45 & 13.9 & 6.2 & 45 \\
\hline PCB 101 & 2.92 & 0.411 & 4.00 & 1.94 & 2.43 & 2.34 & 1.3 & 56 \\
\hline PCB 105 & 6.39 & 4.28 & 3.24 & 2.57 & 2.14 & 3.72 & 1.7 & 46 \\
\hline PCB 106 & 0.313 & 0.209 & 0.0108 & $<\mathrm{LOQ}$ & $<$ LOQ & 0.177 & 0.15 & 86 \\
\hline PCB 107 & 1.23 & 0.350 & 0.316 & 0.203 & 0.153 & 0.450 & 0.44 & 98 \\
\hline PCB 110 & 3.45 & 1.68 & 2.49 & 2.19 & 2.12 & 2.39 & 0.66 & 28 \\
\hline PCB 112 & $<\mathrm{LOD}$ & $<\mathrm{LOD}$ & $<\mathrm{LOD}$ & $<\mathrm{LOD}$ & $<\mathrm{LOD}$ & $<$ LOD & & \\
\hline PCB 114 & 0.621 & 0.442 & 0.330 & 0.250 & 0.228 & 0.374 & 0.16 & 43 \\
\hline PCB 118 & 27.3 & 17.4 & 13.2 & 10.4 & 9.02 & 15.5 & 7.3 & 47 \\
\hline PCB 119 & 0.566 & 0.360 & 0.309 & 0.265 & 0.225 & 0.345 & 0.13 & 39 \\
\hline PCB 127 & $<$ LOD & $<$ LOD & $<\mathrm{LOD}$ & $<\mathrm{LOD}$ & $<\mathrm{LOD}$ & $<$ LOD & & \\
\hline PCB 128 & 5.01 & 3.05 & 2.28 & 1.84 & 1.54 & 2.74 & 1.4 & 51 \\
\hline PCB 130 & 1.43 & 0.872 & 0.780 & 0.458 & 0.418 & 0.793 & 0.41 & 52 \\
\hline PCB 137 & 2.28 & 1.30 & 1.11 & 0.780 & 0.654 & 1.22 & 0.64 & 52 \\
\hline PCB 138 & 36.2 & 21.4 & 16.8 & 12.8 & 10.6 & 19.6 & 10 & 52 \\
\hline PCB 146 & 9.26 & 5.91 & 4.20 & 3.00 & 2.61 & 5.00 & 2.7 & 54 \\
\hline PCB 149 & 3.59 & 2.35 & 2.46 & 1.69 & 1.75 & 2.37 & 0.77 & 32 \\
\hline
\end{tabular}


Appendix 50. (Continued).

\begin{tabular}{|c|c|c|c|c|c|c|c|c|}
\hline Compound & 1371 & 1374 & 1377 & 1379 & 1380 & Mean & SD & RSD \\
\hline PCB 151 & 0.572 & 0.289 & 0.250 & 0.371 & 0.286 & 0.353 & 0.13 & 37 \\
\hline PCB $153+132$ & 71.7 & 43.5 & 34.1 & 24.3 & 20.2 & 38.8 & 21 & 53 \\
\hline PCB 154 & 0.995 & 0.600 & 0.480 & 0.397 & 0.357 & 0.566 & 0.26 & 45 \\
\hline PCB 156 & 2.04 & 1.29 & 0.971 & 0.757 & 0.617 & 1.13 & 0.57 & 50 \\
\hline PCB 157 & 0.582 & 0.387 & 0.308 & 0.223 & 0.197 & 0.340 & 0.15 & 46 \\
\hline PCB 158 & 2.31 & 0.935 & 0.917 & 1.04 & 0.591 & 1.16 & 0.66 & 57 \\
\hline PCB 159 & $<\mathrm{LOQ}$ & $<\mathrm{LOQ}$ & $<\mathrm{LOQ}$ & $<\mathrm{LOQ}$ & $<\mathrm{LOQ}$ & $<$ LOQ & & \\
\hline PCB 163 & 8.29 & 4.63 & 3.64 & 2.96 & 2.34 & 4.37 & 2.3 & 54 \\
\hline PCB 165 & 0.0775 & 0.0267 & 0.0234 & 0.0348 & 0.0281 & 0.0381 & 0.022 & 59 \\
\hline PCB 166 & 0.138 & 0.104 & 0.0643 & 0.0598 & 0.0429 & 0.0817 & 0.038 & 47 \\
\hline PCB 167 & 1.50 & 0.879 & 0.562 & 0.432 & 0.329 & 0.740 & 0.47 & 64 \\
\hline PCB 170 & 5.35 & 2.91 & 2.36 & 1.70 & 1.35 & 2.73 & 1.6 & 58 \\
\hline PCB 172 & 1.04 & 0.680 & 0.493 & 0.344 & 0.263 & 0.563 & 0.31 & 55 \\
\hline PCB 174 & 0.362 & 0.228 & 0.273 & 0.154 & 0.194 & 0.242 & 0.080 & 33 \\
\hline PCB 175 & 0.355 & 0.202 & 0.152 & 0.129 & 0.0954 & 0.187 & 0.10 & 55 \\
\hline PCB 176 & 0.0205 & 0.0173 & 0.0191 & 0.0183 & 0.0160 & 0.0182 & 0.0017 & 9.5 \\
\hline PCB 177 & 1.05 & 0.587 & 0.579 & 0.331 & 0.309 & 0.572 & 0.30 & 52 \\
\hline PCB 178 & 1.17 & 0.602 & 0.426 & 0.455 & 0.271 & 0.585 & 0.35 & 60 \\
\hline PCB $180+193$ & 15.3 & 8.12 & 6.98 & 4.86 & 3.80 & 7.81 & 4.5 & 58 \\
\hline PCB 183 & 5.46 & 3.08 & 2.39 & 1.65 & 1.28 & 2.77 & 1.7 & 60 \\
\hline PCB 185 & 0.0597 & $<\mathrm{LOQ}$ & 0.0512 & 0.0250 & 0.0707 & 0.0517 & 0.019 & 38 \\
\hline PCB 187 & 10.9 & 5.99 & 4.11 & 2.69 & 1.97 & 5.13 & 3.6 & 70 \\
\hline PCB 188 & 0.0300 & 0.0245 & 0.0225 & 0.0204 & 0.0131 & 0.0221 & 0.0062 & 28 \\
\hline PCB 189 & 0.202 & 0.150 & $<\mathrm{LOQ}$ & 0.0672 & 0.0490 & 0.117 & 0.072 & 61 \\
\hline PCB 191 & 0.154 & 0.0841 & 0.114 & 0.0913 & 0.0518 & 0.0991 & 0.038 & 38 \\
\hline PCB 194 & 1.32 & 0.751 & 0.606 & 0.447 & 0.234 & 0.671 & 0.41 & 61 \\
\hline PCB 195 & 0.328 & 0.243 & 0.184 & 0.214 & 0.128 & 0.219 & 0.074 & 34 \\
\hline PCB 196 & 1.96 & 1.37 & 1.13 & 0.946 & 0.807 & 1.24 & 0.45 & 36 \\
\hline PCB 197 & 0.159 & 0.134 & 0.0901 & 0.0920 & 0.0632 & 0.108 & 0.038 & 36 \\
\hline PCB 199 & 5.87 & 4.15 & 3.26 & 2.58 & 1.95 & 3.56 & 1.5 & 43 \\
\hline PCB 200 & $<\mathrm{LOD}$ & $<\mathrm{LOD}$ & $<\mathrm{LOD}$ & $<\mathrm{LOD}$ & $<\mathrm{LOD}$ & $<$ LOD & & \\
\hline PCB 201 & 1.26 & 1.03 & 0.516 & 0.572 & 0.507 & 0.777 & 0.35 & 45 \\
\hline PCB 202 & 0.396 & 0.252 & 0.220 & 0.241 & 0.148 & 0.252 & 0.090 & 36 \\
\hline PCB 205 & 0.0953 & 0.0475 & 0.0532 & 0.0357 & 0.0252 & 0.0514 & 0.027 & 52 \\
\hline PCB 206 & 0.317 & 0.177 & 0.222 & 0.127 & 0.0144 & 0.171 & 0.11 & 65 \\
\hline PCB 207 & 0.149 & 0.104 & 0.0804 & 0.0772 & 0.0538 & 0.0928 & 0.036 & 39 \\
\hline PCB 208 & 0.116 & 0.0754 & 0.0441 & 0.0611 & $<\mathrm{LOQ}$ & 0.0742 & 0.031 & 42 \\
\hline РCB 209 & 0.148 & 0.135 & 0.140 & 0.140 & 0.0521 & 0.123 & 0.040 & 32 \\
\hline
\end{tabular}


Appendix 51. Brominated diphenyl ether (BDE) and polychlorinated biphenyl (PCB) mass fractions (ng g ${ }^{-1}$ wet mass) in glaucous gull eggs collected at Shaktoolik South, Alaska in 2008 (compounds shown in red and blue were above and below reference value ranges, respectively).

\begin{tabular}{|c|c|c|c|c|c|c|c|c|c|c|}
\hline Compound & 1401 & 1402 & 1403 & 1403-2 & 1403 Mean & $\%$ difference & 1404 & Mean & SD & RSD \\
\hline BDE47 & 1.26 & 1.72 & 1.59 & 1.55 & 1.57 & 2.6 & 2.25 & 1.70 & 0.42 & 24 \\
\hline BDE99 & 0.937 & 0.880 & 0.963 & 0.992 & 0.978 & -3.0 & 0.988 & 0.946 & 0.049 & 5.2 \\
\hline BDE100 & 0.740 & 0.714 & 0.906 & 0.897 & 0.901 & 0.97 & 0.884 & 0.810 & 0.097 & 12 \\
\hline PCB 8 & $<\mathrm{LOD}$ & $<\mathrm{LOD}$ & $<\mathrm{LOD}$ & $<\mathrm{LOD}$ & $<$ LOD & & $<\mathrm{LOD}$ & $<$ LOD & & \\
\hline PCB 18 & $<\mathrm{LOD}$ & $<\mathrm{LOD}$ & $<\mathrm{LOD}$ & $<\mathrm{LOD}$ & $<$ LOD & & $<\mathrm{LOD}$ & $<$ LOD & & \\
\hline PCB 28+31 & 2.73 & 3.05 & 4.52 & 4.66 & 4.59 & -3.2 & 5.68 & 4.01 & 1.4 & 34 \\
\hline PCB 29 & $<\mathrm{LOQ}$ & $<$ LOQ & $<\mathrm{LOQ}$ & $<\mathrm{LOQ}$ & $<$ LOQ & & $<$ LOQ & $<$ LOQ & & \\
\hline PCB 44 & 0.0660 & 0.163 & 0.0898 & 0.0931 & 0.0915 & -3.6 & 0.0607 & 0.0954 & 0.047 & 50 \\
\hline PCB 45 & $<$ LOQ & $<$ LOQ & $<$ LOQ & $<$ LOQ & $<$ LOQ & & $<\mathrm{LOQ}$ & $<$ LOQ & & \\
\hline PCB 49 & 0.232 & 0.182 & 0.393 & 0.396 & 0.394 & -0.79 & 0.0704 & 0.220 & 0.13 & 61 \\
\hline PCB 52 & 0.928 & 2.11 & 3.53 & 3.64 & 3.58 & -3.3 & 2.51 & 2.28 & 1.1 & 48 \\
\hline PCB 56 & $<$ LOQ & $<$ LOQ & $<$ LOQ & $<\mathrm{LOQ}$ & $<$ LOQ & & $<$ LOQ & $<$ LOQ & & \\
\hline PCB 63 & $<$ LOQ & $<$ LOQ & $<\mathrm{LOQ}$ & $<$ LOQ & $<\mathrm{LOQ}$ & & $<\mathrm{LOQ}$ & $<$ LOQ & & \\
\hline PCB 66 & 3.03 & 3.43 & 5.23 & 5.28 & 5.26 & -1.1 & 6.65 & 4.59 & 1.7 & 37 \\
\hline PCB 70 & 0.138 & 0.125 & 0.264 & 0.266 & 0.265 & -0.69 & 0.0715 & 0.150 & 0.082 & 55 \\
\hline PCB 74 & 2.92 & 3.30 & 4.46 & 4.50 & 4.48 & -0.77 & 5.71 & 4.10 & 1.3 & 31 \\
\hline PCB 79 & $<$ LOQ & $<$ LOQ & $<$ LOQ & $<\mathrm{LOQ}$ & $<$ LOQ & & $<$ LOQ & $<$ LOQ & & \\
\hline PCB 82 & 0.0159 & 0.0104 & 0.0119 & $<\mathrm{LOD}$ & $<$ LOD & & 0.0213 & 0.0149 & 0.0049 & 33 \\
\hline PCB 87 & 0.448 & 0.445 & 0.835 & 0.850 & 0.843 & -1.8 & 0.624 & 0.590 & 0.19 & 32 \\
\hline PCB 92 & 0.249 & 1.05 & 1.20 & 1.21 & 1.20 & -0.30 & 1.33 & 0.959 & 0.49 & 51 \\
\hline PCB 95+121 & 0.0859 & 0.610 & 0.319 & 0.321 & 0.320 & -0.44 & 0.287 & 0.326 & 0.22 & 66 \\
\hline РCB 99 & 11.4 & 15.6 & 17.6 & 17.3 & 17.4 & 2.0 & 24.0 & 17.1 & 5.2 & 31 \\
\hline PCB 101 & 2.38 & 2.27 & 5.28 & 5.12 & 5.20 & 3.0 & 1.74 & 2.90 & 1.6 & 54 \\
\hline PCB 105 & 2.62 & 3.64 & 5.50 & 5.80 & 5.65 & -5.3 & 7.91 & 4.95 & 2.3 & 47 \\
\hline PCB 106 & $<$ LOQ & 0.333 & 0.130 & 0.131 & 0.131 & -0.87 & 0.227 & 0.230 & 0.10 & 44 \\
\hline PCB 107 & 0.299 & 0.162 & 0.397 & 0.409 & 0.403 & -3.0 & 0.306 & 0.293 & 0.099 & 34 \\
\hline PCB 110 & 1.85 & 2.29 & 4.19 & 4.32 & 4.25 & -3.0 & 4.86 & 3.32 & 1.5 & 44 \\
\hline PCB 112 & $<\mathrm{LOD}$ & $<\mathrm{LOD}$ & 0.0105 & $<\mathrm{LOD}$ & $<$ LOD & & $<\mathrm{LOD}$ & $<$ LOD & & \\
\hline PCB 114 & 0.271 & 0.372 & 0.592 & 0.602 & 0.597 & -1.6 & 0.718 & 0.489 & 0.20 & 42 \\
\hline PCB 118 & 11.6 & 15.0 & 20.8 & 21.2 & 21.0 & -1.9 & 29.9 & 19.4 & 8.0 & 41 \\
\hline PCB 119 & 0.296 & 0.301 & 0.451 & 0.441 & 0.446 & 2.1 & 0.582 & 0.406 & 0.14 & 34 \\
\hline PCB 127 & $<\mathrm{LOD}$ & $<\mathrm{LOD}$ & $<\mathrm{LOD}$ & $<\mathrm{LOD}$ & $<$ LOD & & $<$ LOD & $<$ LOD & & \\
\hline PCB 128 & 2.14 & 2.70 & 3.54 & 3.64 & 3.59 & -2.6 & 4.96 & 3.35 & 1.2 & 37 \\
\hline PCB 130 & 0.548 & 0.658 & 0.973 & 1.01 & 0.990 & -3.6 & 1.30 & 0.873 & 0.34 & 39 \\
\hline PCB 137 & 0.969 & 1.18 & 1.51 & 1.56 & 1.53 & -3.1 & 2.24 & 1.48 & 0.56 & 38 \\
\hline PCB 138 & 15.6 & 20.6 & 24.8 & 24.3 & 24.6 & 2.2 & 34.8 & 23.9 & 8.1 & 34 \\
\hline PCB 146 & 3.98 & 5.04 & 6.04 & 6.33 & 6.19 & -4.6 & 8.04 & 5.81 & 1.7 & 30 \\
\hline PCB 149 & 1.86 & 2.22 & 2.90 & 2.91 & 2.90 & -0.13 & 3.73 & 2.68 & 0.82 & 31 \\
\hline
\end{tabular}


Appendix 51 (Continued).

\begin{tabular}{|c|c|c|c|c|c|c|c|c|c|c|}
\hline Compound & 1401 & 1402 & 1403 & 1403-2 & 1403 Mean & $\%$ difference & 1404 & Mean & SD & RSD \\
\hline PCB 151 & 0.311 & 0.688 & 0.480 & 0.480 & 0.480 & 0.034 & 0.504 & 0.496 & 0.15 & 31 \\
\hline PCB $153+132$ & 33.7 & 46.9 & 45.6 & 46.4 & 46.0 & -1.7 & 64.9 & 47.9 & 13 & 27 \\
\hline PCB 154 & 0.448 & 0.553 & 0.685 & 0.672 & 0.679 & 1.9 & 0.899 & 0.644 & 0.19 & 30 \\
\hline PCB 156 & 0.939 & 1.10 & 1.54 & 1.55 & 1.54 & -0.74 & 2.19 & 1.44 & 0.56 & 39 \\
\hline PCB 157 & 0.295 & 0.357 & 0.460 & 0.451 & 0.455 & 2.0 & 0.661 & 0.442 & 0.16 & 36 \\
\hline PCB 158 & 1.04 & 1.45 & 1.62 & 1.60 & 1.61 & 1.3 & 2.57 & 1.67 & 0.65 & 39 \\
\hline PCB 159 & $<\mathrm{LOQ}$ & $<\mathrm{LOQ}$ & $<\mathrm{LOQ}$ & $<\mathrm{LOQ}$ & $<$ LOQ & & $<\mathrm{LOQ}$ & $<$ LOQ & & \\
\hline PCB 163 & 3.55 & 4.64 & 5.29 & 5.12 & 5.20 & 3.3 & 6.89 & 5.07 & 1.4 & 27 \\
\hline PCB 165 & 0.0401 & 0.0392 & 0.0488 & 0.0488 & 0.0488 & -0.13 & 0.0695 & 0.0494 & 0.014 & 29 \\
\hline PCB 166 & 0.0857 & 0.0775 & 0.100 & 0.103 & 0.101 & -2.6 & 0.132 & 0.0990 & 0.024 & 24 \\
\hline PCB 167 & 0.553 & 0.672 & 1.08 & 1.11 & 1.10 & -2.7 & 1.64 & 0.990 & 0.49 & 50 \\
\hline PCB 170 & 2.21 & 2.77 & 3.33 & 3.33 & 3.33 & 0.12 & 4.93 & 3.31 & 1.2 & 35 \\
\hline PCB 172 & 0.475 & 0.542 & 0.650 & 0.652 & 0.651 & -0.29 & 0.902 & 0.642 & 0.19 & 29 \\
\hline PCB 174 & 0.180 & 0.216 & 0.301 & 0.290 & 0.296 & 3.8 & 0.387 & 0.270 & 0.092 & 34 \\
\hline PCB 175 & 0.126 & 0.144 & 0.243 & 0.239 & 0.241 & 1.6 & 0.293 & 0.201 & 0.079 & 39 \\
\hline PCB 176 & 0.0222 & 0.0105 & 0.0234 & 0.0242 & 0.0238 & -3.5 & 0.0137 & 0.0176 & 0.0064 & 37 \\
\hline PCB 177 & 0.425 & 0.373 & 0.600 & 0.602 & 0.601 & -0.29 & 0.732 & 0.533 & 0.16 & 31 \\
\hline PCB 178 & 0.429 & 0.737 & 0.753 & 0.768 & 0.761 & -2.0 & 1.22 & 0.787 & 0.33 & 42 \\
\hline PCB 180+193 & 6.56 & 8.15 & 9.49 & 9.55 & 9.52 & -0.64 & 14.0 & 9.55 & 3.2 & 33 \\
\hline PCB 183 & 2.23 & 2.91 & 3.26 & 3.37 & 3.31 & -3.5 & 4.72 & 3.29 & 1.1 & 32 \\
\hline PCB 185 & 0.0303 & 0.0199 & 0.0319 & 0.0311 & 0.0315 & 2.6 & 0.0172 & 0.0247 & 0.0072 & 29 \\
\hline PCB 187 & 3.50 & 4.53 & 6.00 & 6.54 & 6.27 & -8.5 & 8.85 & 5.79 & 2.3 & 40 \\
\hline PCB 188 & 0.0561 & 0.0206 & 0.0192 & 0.0192 & 0.0192 & 0.29 & 0.0415 & 0.0343 & 0.018 & 52 \\
\hline PCB 189 & 0.0772 & 0.0188 & $<\mathrm{LOQ}$ & 0.0593 & $<\mathbf{L O Q}$ & & 0.217 & 0.0930 & 0.086 & 92 \\
\hline PCB 191 & 0.0946 & 0.0911 & 0.151 & 0.145 & 0.148 & 3.9 & 0.185 & 0.130 & 0.045 & 35 \\
\hline PCB 194 & 0.580 & 0.663 & 0.887 & 0.864 & 0.876 & 2.6 & 1.41 & 0.882 & 0.37 & 42 \\
\hline PCB 195 & 0.257 & 0.187 & 0.260 & 0.265 & 0.263 & -2.1 & 0.312 & 0.255 & 0.052 & 20 \\
\hline PCB 196 & 1.18 & 1.18 & 1.49 & 1.50 & 1.49 & -0.45 & 1.88 & 1.43 & 0.33 & 23 \\
\hline PCB 197 & 0.0720 & 0.0804 & 0.122 & 0.118 & 0.120 & 3.2 & 0.130 & 0.101 & 0.029 & 28 \\
\hline PCB 199 & 2.84 & 3.46 & 3.87 & 3.86 & 3.87 & 0.22 & 5.25 & 3.85 & 1.0 & 26 \\
\hline PCB 200 & $<\mathrm{LOD}$ & $<\mathrm{LOD}$ & $<\mathrm{LOD}$ & $<$ LOD & $<$ LOD & & $<\mathrm{LOD}$ & $<$ LOD & & \\
\hline PCB 201 & 0.815 & 0.766 & 0.740 & 0.752 & 0.746 & -1.6 & 1.14 & 0.867 & 0.19 & 21 \\
\hline PCB 202 & 0.242 & 0.311 & 0.254 & 0.261 & 0.257 & -2.6 & 0.386 & 0.299 & 0.065 & 22 \\
\hline PCB 205 & 0.0577 & 0.0498 & 0.0264 & 0.0244 & 0.0254 & 8.0 & 0.0761 & 0.0523 & 0.021 & 40 \\
\hline PCB 206 & 0.0923 & 0.242 & 0.439 & 0.431 & 0.435 & 1.9 & 0.433 & 0.300 & 0.17 & 55 \\
\hline PCB 207 & 0.0900 & 0.0767 & 0.0969 & 0.0943 & 0.0956 & 2.7 & 0.136 & 0.0996 & 0.026 & 26 \\
\hline PCB 208 & 0.0299 & 0.0360 & 0.0576 & 0.0582 & 0.0579 & -0.92 & 0.0807 & 0.0511 & 0.023 & 45 \\
\hline PCB 209 & 0.0892 & 0.137 & 0.206 & 0.201 & 0.204 & 2.8 & 0.191 & 0.155 & 0.053 & 34 \\
\hline
\end{tabular}


Appendix 52. Brominated diphenyl ether (BDE) and polychlorinated biphenyl (PCB) mass fractions (ng $\mathrm{g}^{-1}$ wet mass) in glaucous gull eggs collected at Shaktoolik South, Alaska in 2009 (compounds shown in red and blue were above and below reference value ranges, respectively).

\begin{tabular}{|c|c|c|c|c|c|c|c|c|}
\hline Compound & 1424 & 1426 & 1427 & 1428 & 1429 & Mean & SD & RSD \\
\hline BDE47 & 1.72 & 0.875 & 0.941 & 5.46 & 1.54 & 2.11 & 1.9 & 91 \\
\hline BDE99 & 0.641 & 0.167 & 0.200 & 6.09 & 0.230 & 1.46 & 2.6 & 180 \\
\hline BDE100 & 0.522 & 0.230 & 0.370 & 1.65 & 0.387 & 0.631 & 0.58 & 91 \\
\hline PCB 8 & $<$ LOD & $<\mathrm{LOD}$ & $<$ LOD & $<$ LOD & $<\mathrm{LOD}$ & $<$ LOD & & \\
\hline PCB 18 & $<\mathrm{LOD}$ & $<\mathrm{LOD}$ & $<$ LOD & $<$ LOD & $<\mathrm{LOD}$ & $<\mathbf{L O D}$ & & \\
\hline PCB28+31 & 2.58 & 1.83 & 2.27 & 2.46 & 2.81 & 2.39 & 0.37 & 15 \\
\hline PCB 29 & $<$ LOD & $<$ LOD & $<$ LOD & $<$ LOD & $<$ LOD & $<$ LOD & & \\
\hline PCB 44 & 0.176 & 0.0654 & 0.0698 & 0.132 & 0.0988 & 0.108 & 0.046 & 43 \\
\hline PCB 45 & $<$ LOQ & $<$ LOQ & $<$ LOQ & $<$ LOQ & $<\mathrm{LOQ}$ & $<\mathbf{L O Q}$ & & \\
\hline PCB 49 & 0.730 & 0.0635 & 0.0529 & 0.151 & 0.184 & 0.236 & 0.28 & 120 \\
\hline PCB 52 & 3.68 & 0.856 & 1.79 & 1.14 & 1.13 & 1.72 & 1.1 & 67 \\
\hline PCB 56 & 0.170 & 0.150 & 0.162 & 0.193 & 0.162 & 0.167 & 0.016 & 9.6 \\
\hline PCB 63 & 0.128 & 0.138 & 0.124 & 0.203 & 0.120 & 0.143 & 0.034 & 24 \\
\hline PCB 66 & 3.53 & 2.60 & 2.91 & 2.12 & 3.80 & 2.99 & 0.68 & 23 \\
\hline PCB 70 & 0.102 & 0.0553 & 0.0647 & 0.139 & 0.121 & 0.0965 & 0.036 & 37 \\
\hline РCB 74 & 3.21 & 2.50 & 2.50 & 1.76 & 3.20 & 2.63 & 0.60 & 23 \\
\hline РCB 79 & 0.0295 & 0.0321 & 0.0272 & 0.0440 & 0.0268 & 0.0319 & 0.0071 & 22 \\
\hline PCB 82 & 0.0613 & 0.0280 & 0.0329 & 0.0337 & 0.0278 & 0.0367 & 0.014 & 38 \\
\hline PCB 87 & 1.08 & 0.364 & 0.378 & 0.625 & 0.567 & 0.602 & 0.29 & 48 \\
\hline РCB 92 & 1.40 & 0.273 & 0.650 & 0.315 & 0.607 & 0.649 & 0.45 & 70 \\
\hline PCB 95+121 & 0.750 & 0.0692 & 0.141 & 0.0710 & 0.284 & 0.263 & 0.29 & 110 \\
\hline РCB 99 & 19.1 & 14.0 & 11.9 & 25.0 & 15.3 & 17.1 & 5.2 & 30 \\
\hline PCB 101 & 6.49 & 1.34 & 1.29 & 1.71 & 3.17 & 2.80 & 2.2 & 79 \\
\hline PCB 105 & 4.67 & 3.31 & 3.38 & 5.25 & 4.31 & 4.18 & 0.83 & 20 \\
\hline PCB 106 & 0.0296 & 0.0286 & $<$ LOQ & 0.0282 & 0.0445 & 0.0327 & 0.0079 & 24 \\
\hline PCB 107 & 0.342 & 0.173 & 0.173 & 0.261 & 0.276 & 0.245 & 0.073 & 30 \\
\hline PCB 110 & 4.07 & 1.46 & 1.57 & 3.82 & 2.72 & 2.73 & 1.2 & 45 \\
\hline PCB 112 & 0.0207 & 0.00838 & 0.0112 & 0.0241 & 0.0176 & 0.0164 & 0.0065 & 40 \\
\hline PCB 114 & 0.456 & 0.326 & 0.319 & 0.549 & 0.403 & 0.411 & 0.096 & 23 \\
\hline PCB 118 & 17.4 & 13.7 & 12.3 & 21.8 & 16.0 & 16.2 & 3.7 & 23 \\
\hline PCB 119 & 0.502 & 0.319 & 0.301 & 0.592 & 0.374 & 0.418 & 0.13 & 30 \\
\hline PCB 127 & $<$ LOQ & $<$ LOQ & $<$ LOQ & $<\mathrm{LOQ}$ & $<\mathrm{LOQ}$ & $<\mathbf{L O Q}$ & & \\
\hline PCB 128 & 3.03 & 2.29 & 2.00 & 3.69 & 2.71 & 2.74 & 0.66 & 24 \\
\hline PCB 130 & 0.789 & 0.483 & 0.519 & 1.08 & 0.706 & 0.717 & 0.24 & 34 \\
\hline PCB 137 & 1.21 & 0.912 & 0.742 & 1.66 & 1.12 & 1.13 & 0.35 & 31 \\
\hline PCB 138 & 20.9 & 16.8 & 12.6 & 28.2 & 17.9 & 19.3 & 5.8 & 30 \\
\hline PCB 146 & 5.08 & 4.05 & 3.19 & 7.49 & 4.75 & 4.91 & 1.6 & 33 \\
\hline PCB 149 & 4.23 & 1.15 & 1.44 & 2.49 & 2.57 & 2.38 & 1.2 & 51 \\
\hline
\end{tabular}


Appendix 52 (Continued).

\begin{tabular}{|c|c|c|c|c|c|c|c|c|}
\hline Compound & 1424 & 1426 & 1427 & 1428 & 1429 & Mean & SD & RSD \\
\hline PCB 151 & 0.921 & 0.0870 & 0.115 & 0.171 & 0.340 & 0.327 & 0.35 & 110 \\
\hline PCB $153+132$ & 39.7 & 42.3 & 24.7 & 66.3 & 38.7 & 42.4 & 15 & 36 \\
\hline PCB 154 & 0.601 & 0.411 & 0.378 & 0.781 & 0.503 & 0.535 & 0.16 & 30 \\
\hline PCB 156 & 1.09 & 0.817 & 0.719 & 1.56 & 1.07 & 1.05 & 0.33 & 31 \\
\hline PCB 157 & 0.308 & 0.244 & 0.214 & 0.390 & 0.306 & 0.292 & 0.068 & 23 \\
\hline PCB 158 & 1.31 & 1.11 & 0.620 & 1.13 & 1.12 & 1.06 & 0.26 & 24 \\
\hline PCB 159 & $<$ LOQ & $<$ LOQ & $<\mathrm{LOQ}$ & 0.0124 & $<\mathrm{LOQ}$ & $<\mathbf{L O Q}$ & & \\
\hline PCB 163 & 4.19 & 3.54 & 3.05 & 5.77 & 4.04 & 4.12 & 1.0 & 25 \\
\hline PCB 165 & 0.0446 & 0.0426 & 0.0359 & 0.0455 & 0.0489 & 0.0435 & 0.0048 & 11 \\
\hline PCB 166 & 0.231 & 0.0321 & 0.0350 & 0.0993 & 0.144 & 0.108 & 0.083 & 77 \\
\hline PCB 167 & 0.857 & 0.653 & 0.576 & 1.00 & 0.855 & 0.789 & 0.17 & 22 \\
\hline PCB 170 & 2.35 & 2.14 & 1.62 & 3.68 & 2.80 & 2.52 & 0.77 & 31 \\
\hline PCB 172 & 0.529 & 0.435 & 0.304 & 0.778 & 0.562 & 0.522 & 0.18 & 34 \\
\hline PCB 174 & 0.501 & 0.106 & 0.157 & 0.302 & 0.385 & 0.290 & 0.16 & 56 \\
\hline PCB 175 & 0.220 & 0.153 & 0.131 & 0.277 & 0.212 & 0.199 & 0.058 & 29 \\
\hline PCB 176 & 0.0734 & 0.0349 & 0.0362 & 0.0424 & 0.0478 & 0.0469 & 0.016 & 33 \\
\hline PCB 177 & 0.743 & 0.311 & 0.486 & 0.849 & 0.586 & 0.595 & 0.21 & 36 \\
\hline PCB 178 & 0.910 & 0.690 & 0.588 & 0.875 & 0.734 & 0.759 & 0.13 & 18 \\
\hline PCB $180+193$ & 7.67 & 6.53 & 4.52 & 11.5 & 8.16 & 7.68 & 2.6 & 33 \\
\hline PCB 183 & 2.82 & 2.40 & 1.62 & 3.89 & 2.86 & 2.72 & 0.82 & 30 \\
\hline PCB 185 & 0.0431 & $<\mathrm{LOQ}$ & $<\mathrm{LOQ}$ & $<\mathrm{LOQ}$ & 0.0360 & 0.0395 & 0.0050 & 13 \\
\hline PCB 187 & 6.08 & 3.74 & 3.66 & 8.09 & 5.82 & 5.48 & 1.8 & 34 \\
\hline PCB 188 & 0.0386 & 0.0247 & 0.0288 & 0.0443 & 0.0374 & 0.0348 & 0.0079 & 23 \\
\hline PCB 189 & $<$ LOQ & $<$ LOQ & $<\mathrm{LOQ}$ & 0.0257 & $<\mathrm{LOQ}$ & $<\mathbf{L O Q}$ & & \\
\hline PCB 191 & 0.0961 & 0.0796 & 0.0651 & 0.136 & 0.0957 & 0.0945 & 0.026 & 28 \\
\hline PCB 194 & 0.541 & 0.578 & 0.348 & 0.778 & 0.690 & 0.587 & 0.16 & 28 \\
\hline PCB 195 & $<\mathrm{LOQ}$ & 0.138 & 0.118 & 0.0529 & 0.200 & 0.127 & 0.061 & 48 \\
\hline PCB 196 & 1.11 & 0.887 & 0.662 & 1.69 & 1.26 & 1.12 & 0.39 & 35 \\
\hline PCB 197 & 0.0999 & 0.0732 & 0.0591 & 0.139 & 0.100 & 0.0942 & 0.030 & 32 \\
\hline PCB 199 & 3.14 & 2.49 & 1.60 & 5.38 & 3.44 & 3.21 & 1.4 & 44 \\
\hline PCB 200 & $<$ LOQ & $<$ LOQ & $<$ LOQ & $<\mathrm{LOQ}$ & $<\mathrm{LOQ}$ & $<$ LOQ & & \\
\hline PCB 201 & 1.04 & 0.387 & 0.537 & 1.42 & 0.904 & $\mathbf{0 . 8 5 7}$ & 0.41 & 48 \\
\hline PCB 202 & 0.374 & 0.391 & 0.234 & 0.504 & 0.348 & 0.370 & 0.097 & 26 \\
\hline PCB 205 & 0.0415 & 0.0429 & 0.0400 & 0.0442 & 0.0493 & 0.0436 & 0.0036 & 8.2 \\
\hline PCB 206 & $<$ LOQ & 0.239 & $<\mathrm{LOQ}$ & 0.345 & 0.265 & 0.283 & 0.056 & 20 \\
\hline PCB 207 & 0.0870 & 0.0761 & 0.0671 & 0.120 & 0.0926 & 0.0886 & 0.020 & 23 \\
\hline PCB 208 & $<\mathrm{LOQ}$ & 0.139 & 0.0845 & 0.168 & 0.144 & 0.134 & 0.035 & 26 \\
\hline PCB 209 & 0.0901 & 0.104 & 0.0689 & 0.120 & 0.110 & 0.0987 & 0.020 & 20 \\
\hline
\end{tabular}


Appendix 53. Brominated diphenyl ether (BDE) and polychlorinated biphenyl (PCB) mass fractions (ng g ${ }^{-1}$ wet mass) in glaucous gull eggs collected at Stuart Island, Alaska in 2009 (compounds shown in red and blue were above and below reference value ranges, respectively).

\begin{tabular}{|c|c|c|c|c|c|c|c|c|}
\hline Compound & 1419 & 1420 & 1421 & 1422 & 1423 & Mean & SD & RSD \\
\hline BDE47 & 1.33 & 2.48 & 1.11 & 2.21 & 1.67 & 1.76 & 0.58 & 33 \\
\hline BDE99 & 0.801 & 0.934 & 0.526 & 0.539 & 0.301 & 0.620 & 0.25 & 40 \\
\hline BDE100 & 2.01 & 1.03 & 1.15 & 0.613 & 0.420 & 1.04 & 0.62 & 59 \\
\hline PCB 8 & $<\mathrm{LOD}$ & $<\mathrm{LOD}$ & $<\mathrm{LOD}$ & $<\mathrm{LOD}$ & $<\mathrm{LOD}$ & $<$ LOD & & \\
\hline PCB 18 & $<\mathrm{LOD}$ & $<\mathrm{LOD}$ & $<\mathrm{LOD}$ & $<\mathrm{LOD}$ & $<\mathrm{LOD}$ & $<$ LOD & & \\
\hline PCB28+31 & 0.416 & 2.70 & 0.310 & 2.65 & 3.30 & 1.88 & 1.4 & 75 \\
\hline PCB 29 & $<\mathrm{LOD}$ & $<$ LOD & $<\mathrm{LOD}$ & $<$ LOD & $<\mathrm{LOD}$ & $<$ LOD & & \\
\hline PCB 44 & 0.0598 & 0.0592 & 0.0606 & 0.0577 & 0.0763 & 0.0627 & 0.0077 & 12 \\
\hline PCB 45 & $<\mathrm{LOQ}$ & $<\mathrm{LOQ}$ & $<\mathrm{LOQ}$ & $<\mathrm{LOQ}$ & $<\mathrm{LOQ}$ & $<\mathbf{L O Q}$ & & \\
\hline РCB 49 & 0.0878 & 0.0722 & 0.0767 & 0.0699 & 0.519 & 0.165 & 0.20 & 120 \\
\hline PCB 52 & 0.110 & 0.757 & 0.117 & 0.725 & 1.93 & 0.728 & 0.74 & 100 \\
\hline PCB 56 & 0.142 & 0.277 & 0.132 & 0.185 & 0.297 & 0.207 & 0.076 & 37 \\
\hline PCB 63 & 0.0526 & 0.0786 & 0.0421 & 0.0946 & 0.151 & 0.0838 & 0.043 & 51 \\
\hline PCB 66 & 0.640 & 4.89 & 0.533 & 4.80 & 4.37 & 3.05 & 2.3 & 74 \\
\hline PCB 70 & 0.0774 & 0.0589 & 0.0859 & 0.0834 & 0.172 & 0.0955 & 0.044 & 46 \\
\hline PCB 74 & 0.496 & 4.80 & 0.401 & 4.66 & 3.51 & 2.77 & 2.2 & 79 \\
\hline РCB 79 & $<\mathrm{LOQ}$ & $<\mathrm{LOQ}$ & $<$ LOQ & $<$ LOQ & $<\mathrm{LOQ}$ & $<$ LOQ & & \\
\hline PCB 82 & 0.0381 & 0.0430 & 0.0321 & 0.0284 & 0.0522 & 0.0387 & 0.0094 & 24 \\
\hline PCB 87 & 0.154 & 0.779 & 0.129 & 0.691 & 0.573 & 0.465 & 0.30 & 65 \\
\hline PCB 92 & 0.368 & 0.346 & 0.317 & 0.339 & 0.704 & 0.415 & 0.16 & 39 \\
\hline PCB 95+121 & 0.170 & 0.202 & 0.156 & 0.199 & 0.196 & 0.185 & 0.020 & 11 \\
\hline PCB 99 & 2.45 & 35.6 & 1.76 & 32.1 & 13.7 & 17.1 & 16 & 94 \\
\hline PCB 101 & 0.260 & 2.80 & 0.240 & 2.66 & 5.07 & 2.21 & 2.0 & 92 \\
\hline PCB 105 & 0.937 & 6.94 & 0.761 & 6.44 & 4.40 & 3.90 & 2.9 & 75 \\
\hline PCB 106 & 0.0189 & 0.201 & 0.0361 & 0.0224 & 0.0215 & 0.0600 & 0.079 & 130 \\
\hline PCB 107 & 0.165 & 0.270 & 0.128 & 0.361 & 0.272 & 0.239 & 0.093 & 39 \\
\hline PCB 110 & $<\mathrm{LOD}$ & 3.01 & $<\mathrm{LOD}$ & 2.79 & 3.81 & 3.20 & 0.54 & 17 \\
\hline PCB 112 & 0.0106 & 0.109 & 0.00782 & 0.0336 & 0.0218 & 0.0366 & 0.042 & 110 \\
\hline PCB 114 & 0.0690 & 0.720 & 0.0621 & 0.686 & 0.388 & 0.385 & 0.32 & 83 \\
\hline PCB 118 & 3.47 & 30.4 & 2.84 & 28.0 & 15.9 & 16.1 & 13 & 81 \\
\hline PCB 119 & 0.0225 & 0.716 & 0.0224 & 0.655 & 0.363 & 0.356 & 0.33 & 93 \\
\hline PCB 127 & $<\mathrm{LOQ}$ & $<\mathrm{LOQ}$ & $<\mathrm{LOQ}$ & $<$ LOQ & $<\mathrm{LOQ}$ & $<$ LOQ & & \\
\hline PCB 128 & 0.656 & 6.83 & 0.528 & 6.28 & 2.70 & 3.40 & 3.0 & 89 \\
\hline PCB 130 & 0.127 & 2.29 & 0.110 & 2.13 & 0.586 & 1.05 & 1.1 & 100 \\
\hline PCB 137 & 0.162 & 3.24 & 0.139 & 3.01 & 1.03 & 1.52 & 1.5 & 100 \\
\hline PCB 138 & 4.01 & 52.1 & 3.23 & 45.4 & 17.4 & 24.4 & 23 & 94 \\
\hline PCB 146 & 1.27 & 12.8 & 1.00 & 11.8 & 4.31 & 6.24 & 5.7 & 91 \\
\hline PCB 149 & 0.540 & 4.81 & 0.455 & 4.46 & 2.41 & 2.53 & 2.1 & 82 \\
\hline
\end{tabular}


Appendix 53 (Continued).

\begin{tabular}{|c|c|c|c|c|c|c|c|c|}
\hline Compound & 1419 & 1420 & 1421 & 1422 & 1423 & Mean & SD & RSD \\
\hline PCB 151 & 0.244 & 0.0945 & 0.201 & 0.0901 & 0.0635 & 0.139 & 0.079 & 57 \\
\hline PCB $153+132$ & 10.7 & 98.7 & 8.44 & 90.4 & 33.8 & 48.4 & 43 & 90 \\
\hline PCB 154 & 0.138 & 1.33 & 0.115 & 1.20 & 0.460 & 0.649 & 0.58 & 90 \\
\hline PCB 156 & 0.304 & 2.46 & 0.259 & 2.24 & 1.10 & 1.27 & 1.0 & 82 \\
\hline PCB 157 & 0.0888 & 2.29 & 0.0801 & 2.22 & 0.306 & 0.999 & 1.2 & 120 \\
\hline PCB 158 & 0.185 & 2.41 & 0.220 & 2.16 & 1.01 & 1.20 & 1.1 & 88 \\
\hline РCB 159 & $<\mathrm{LOQ}$ & 0.00278 & $<\mathrm{LOQ}$ & $<\mathrm{LOQ}$ & $<\mathrm{LOQ}$ & $<\mathrm{LOQ}$ & & \\
\hline РCB 163 & 1.07 & 10.4 & 0.880 & 9.73 & 3.32 & 5.08 & 4.7 & 92 \\
\hline PCB 165 & 0.0390 & 0.109 & 0.0368 & 0.0916 & 0.317 & 0.119 & 0.12 & 97 \\
\hline РCB 166 & 0.104 & 0.303 & 0.0579 & 0.337 & 0.0751 & 0.175 & 0.13 & 76 \\
\hline PCB 167 & 0.260 & 1.96 & 0.204 & 1.83 & 0.875 & 1.03 & 0.84 & 82 \\
\hline PCB 170 & 1.07 & 8.61 & 0.915 & 7.83 & 2.51 & 4.19 & 3.7 & 89 \\
\hline PCB 172 & 0.189 & 1.80 & 0.158 & 1.68 & 0.479 & 0.862 & 0.81 & 94 \\
\hline PCB 174 & 0.155 & 0.690 & 0.127 & 0.660 & 0.333 & 0.393 & 0.27 & 69 \\
\hline PCB 175 & 0.0598 & 0.739 & 0.0481 & 0.686 & 0.185 & 0.344 & 0.34 & 99 \\
\hline PCB 176 & 0.0384 & 0.0449 & 0.0369 & 0.0393 & 0.0391 & 0.0397 & 0.0031 & 7.7 \\
\hline РCB 177 & 0.491 & 2.46 & 0.377 & 2.34 & 0.379 & 1.21 & 1.1 & 90 \\
\hline PCB 178 & 0.451 & 1.66 & 0.336 & 1.57 & 0.524 & 0.907 & 0.65 & 71 \\
\hline PCB 180+193 & 3.39 & 25.7 & 2.67 & 24.0 & 7.37 & 12.6 & 11 & 90 \\
\hline PCB 183 & 0.949 & 8.90 & 0.707 & 8.39 & 2.47 & 4.28 & 4.0 & 94 \\
\hline PCB 185 & $<\mathrm{LOQ}$ & 0.0231 & $<\mathrm{LOQ}$ & 0.0207 & 0.0241 & 0.0226 & 0.0018 & 7.7 \\
\hline PCB 187 & 1.91 & 20.0 & 1.36 & 18.9 & 4.66 & 9.38 & 9.3 & 99 \\
\hline PCB 188 & 0.0197 & 0.0617 & 0.0193 & 0.0586 & 0.0255 & 0.0369 & 0.021 & 58 \\
\hline PCB 189 & $<$ LOQ & $<\mathrm{LOQ}$ & $<\mathrm{LOQ}$ & 0.245 & 0.105 & 0.175 & 0.099 & 56 \\
\hline РCB 191 & 0.0401 & 0.264 & 0.0390 & 0.246 & 0.0916 & 0.136 & 0.11 & 81 \\
\hline РCB 194 & 0.509 & 1.82 & 0.422 & 1.70 & 0.642 & 1.02 & 0.68 & 67 \\
\hline PCB 195 & 0.0526 & 0.543 & 0.0504 & 0.519 & 0.197 & 0.272 & 0.24 & 89 \\
\hline РCB 196 & 0.754 & 3.24 & 0.609 & 3.18 & 1.17 & 1.79 & 1.3 & 73 \\
\hline РCB 197 & 0.0467 & 0.263 & 0.0457 & 0.259 & 0.0858 & 0.140 & 0.11 & 80 \\
\hline РCB 199 & 2.05 & 12.6 & 1.56 & 12.2 & 2.88 & 6.26 & 5.6 & 90 \\
\hline PCB 200 & $<\mathrm{LOQ}$ & $<\mathrm{LOQ}$ & $<\mathrm{LOQ}$ & $<\mathrm{LOQ}$ & $<\mathrm{LOQ}$ & $<\mathrm{LOQ}$ & & \\
\hline РCB 201 & 0.523 & 2.82 & 0.373 & 2.84 & 0.631 & 1.44 & 1.3 & 89 \\
\hline РCB 202 & 0.194 & 0.702 & 0.181 & 0.691 & 0.228 & 0.399 & 0.27 & 68 \\
\hline РCB 205 & $<\mathrm{LOQ}$ & 0.0801 & $<\mathrm{LOQ}$ & 0.0967 & 0.0398 & 0.0722 & 0.029 & 41 \\
\hline РCB 206 & 0.248 & 0.456 & 0.212 & 0.477 & 0.233 & 0.326 & 0.13 & 40 \\
\hline PCB 207 & 0.0591 & 0.214 & 0.0542 & 0.219 & 0.0921 & 0.128 & 0.082 & 65 \\
\hline РCB 208 & 0.101 & 0.176 & 0.104 & 0.291 & 0.126 & 0.160 & 0.080 & 50 \\
\hline РCB 209 & 0.119 & 0.220 & 0.0713 & 0.239 & 0.0822 & 0.146 & 0.078 & 53 \\
\hline
\end{tabular}


Appendix 54. Brominated diphenyl ether (BDE) and polychlorinated biphenyl (PCB) mass fractions (ng $\mathrm{g}^{-1}$ wet mass) in glaucous-winged gull eggs collected at Aiktak Island, Alaska in 2009 (compounds shown in red and blue were above and below reference value ranges, respectively).

\begin{tabular}{|c|c|c|c|c|c|c|c|c|}
\hline Compound & 1473 & 1474 & 1475 & 1477 & 1478 & Mean & SD & RSD \\
\hline BDE47 & 0.477 & 4.90 & 0.906 & 2.52 & 1.78 & 2.12 & 1.7 & 82 \\
\hline BDE99 & 0.0797 & 0.990 & 0.328 & 0.353 & 0.200 & 0.390 & 0.35 & 90 \\
\hline BDE100 & 0.231 & 1.32 & 0.431 & 0.653 & 0.471 & 0.620 & 0.42 & 67 \\
\hline PCB 8 & $<\mathrm{LOD}$ & $<\mathrm{LOD}$ & $<$ LOD & $<$ LOD & $<\mathrm{LOD}$ & $<\mathbf{L O D}$ & & \\
\hline PCB 18 & $<\mathrm{LOD}$ & $<$ LOD & $<\mathrm{LOD}$ & $<$ LOD & $<\mathrm{LOD}$ & $<$ LOD & & \\
\hline PCB28+31 & 0.419 & 1.44 & 1.02 & 2.04 & 1.75 & 1.33 & 0.64 & 48 \\
\hline РCB 29 & $<\mathrm{LOD}$ & $<\mathrm{LOD}$ & $<\mathrm{LOD}$ & $<\mathrm{LOD}$ & $<\mathrm{LOD}$ & $<$ LOD & & \\
\hline PCB 44 & 0.122 & 0.0581 & 0.103 & 0.167 & 0.0846 & 0.107 & 0.041 & 38 \\
\hline PCB 45 & $<\mathrm{LOQ}$ & $<\mathrm{LOQ}$ & $<$ LOQ & $<$ LOQ & $<\mathrm{LOQ}$ & $<\mathbf{L O Q}$ & & \\
\hline PCB 49 & 0.134 & 0.0844 & 0.134 & 0.187 & 0.0649 & 0.121 & 0.048 & 40 \\
\hline PCB 52 & 0.436 & 0.584 & 1.07 & 0.725 & 0.412 & 0.645 & 0.27 & 42 \\
\hline PCB 56 & 0.149 & 0.228 & 0.195 & 0.212 & 0.213 & 0.199 & 0.030 & 15 \\
\hline PCB 63 & 0.0722 & 0.168 & 0.0955 & 0.106 & 0.0613 & 0.101 & 0.042 & 41 \\
\hline PCB 66 & 0.556 & 4.14 & 1.38 & 2.94 & 2.92 & 2.39 & 1.4 & 59 \\
\hline PCB 70 & 0.0783 & 0.0686 & 0.0614 & 0.0759 & 0.0767 & 0.0722 & 0.0071 & 9.8 \\
\hline РCB 74 & 0.428 & 3.28 & 1.02 & 2.40 & 2.17 & 1.86 & 1.1 & 61 \\
\hline РCB 79 & 0.0287 & 0.0275 & 0.0256 & 0.0294 & 0.0250 & 0.0272 & 0.0019 & 7.1 \\
\hline PCB 82 & 0.0295 & 0.0284 & 0.0336 & 0.0293 & 0.0314 & 0.0304 & 0.0021 & 6.9 \\
\hline PCB 87 & 0.153 & 0.600 & 0.214 & 0.500 & 0.352 & 0.364 & 0.19 & 52 \\
\hline PCB 92 & 0.184 & 0.224 & 0.356 & 0.424 & 0.168 & 0.271 & 0.11 & 42 \\
\hline PCB 95+121 & 0.162 & 0.135 & 0.204 & 0.240 & 0.113 & 0.171 & 0.051 & 30 \\
\hline PCB 99 & 2.65 & 25.6 & 5.99 & 14.6 & 12.5 & 12.3 & 8.9 & 72 \\
\hline PCB 101 & 0.754 & 0.573 & 1.56 & 2.23 & 0.600 & 1.14 & 0.73 & 64 \\
\hline PCB 105 & 0.645 & 6.42 & 1.48 & 3.56 & 3.13 & 3.05 & 2.2 & 73 \\
\hline PCB 106 & $<\mathrm{LOQ}$ & 0.0195 & 0.0385 & 0.0230 & 0.0183 & 0.0248 & 0.0093 & 38 \\
\hline PCB 107 & 0.0783 & 0.106 & 0.0868 & 0.0966 & 0.112 & 0.0960 & 0.014 & 14 \\
\hline PCB 110 & 0.325 & 0.634 & 1.01 & 0.902 & 0.573 & 0.689 & 0.27 & 40 \\
\hline PCB 112 & 0.00844 & 0.0212 & 0.0115 & 0.0329 & 0.0150 & 0.0178 & 0.0097 & 54 \\
\hline РCB 114 & 0.0737 & 0.733 & 0.147 & 0.348 & 0.335 & 0.327 & 0.26 & 78 \\
\hline PCB 118 & 2.84 & 28.1 & 6.14 & 14.5 & 13.2 & 13.0 & 9.8 & 75 \\
\hline PCB 119 & 0.0506 & 0.635 & 0.157 & 0.383 & 0.325 & 0.310 & 0.22 & 72 \\
\hline PCB 127 & $<\mathrm{LOQ}$ & $<$ LOQ & $<$ LOQ & $<$ LOQ & $<\mathrm{LOQ}$ & $<\mathbf{L O Q}$ & & \\
\hline PCB 128 & 0.535 & 5.35 & 1.11 & 2.65 & 2.33 & 2.39 & 1.9 & 78 \\
\hline PCB 130 & 0.243 & 0.740 & 0.375 & 0.656 & 0.646 & 0.532 & 0.21 & 40 \\
\hline РCB 137 & 0.235 & 2.34 & 0.446 & 0.973 & 0.966 & 0.992 & 0.82 & 83 \\
\hline PCB 138 & 4.62 & 37.6 & 8.46 & 19.3 & 18.9 & 17.8 & 13 & 72 \\
\hline PCB 146 & 1.18 & 7.08 & 2.57 & 5.40 & 4.79 & 4.20 & 2.3 & 56 \\
\hline РCB 149 & 0.558 & 1.36 & 1.34 & 1.23 & 0.875 & 1.07 & 0.35 & 33 \\
\hline
\end{tabular}


Appendix 54 (Continued).

\begin{tabular}{|c|c|c|c|c|c|c|c|c|}
\hline Compound & 1473 & 1474 & 1475 & 1477 & 1478 & Mean & SD & RSD \\
\hline PCB 151 & 0.100 & 0.138 & 0.223 & 0.165 & 0.0694 & 0.139 & 0.059 & 43 \\
\hline PCB $153+132$ & 9.48 & 94.9 & 19.9 & 43.3 & 39.8 & 41.5 & 33 & 80 \\
\hline PCB 154 & 0.146 & 1.17 & 0.279 & 0.642 & 0.512 & 0.550 & 0.40 & 72 \\
\hline PCB 156 & 0.180 & 2.17 & 0.439 & 0.909 & 0.948 & 0.928 & 0.76 & 82 \\
\hline PCB 157 & 0.0725 & 0.618 & 0.127 & 0.266 & 0.249 & 0.267 & 0.21 & 80 \\
\hline PCB 158 & 0.299 & 2.15 & 0.576 & 1.37 & 1.18 & 1.12 & 0.72 & 65 \\
\hline PCB 159 & $<\mathrm{LOQ}$ & $<\mathrm{LOQ}$ & $<\mathrm{LOQ}$ & $<\mathrm{LOQ}$ & $<$ LOQ & $<\mathbf{L O Q}$ & & \\
\hline PCB 163 & 0.881 & 5.80 & 1.98 & 3.89 & 3.28 & 3.17 & 1.9 & 59 \\
\hline PCB 165 & 0.0337 & 0.105 & 0.0457 & 0.0706 & 0.0698 & 0.0649 & 0.027 & 42 \\
\hline PCB 166 & 0.0276 & 0.0404 & 0.0340 & 0.0316 & 0.0359 & 0.0339 & 0.0048 & 14 \\
\hline PCB 167 & 0.184 & 1.94 & 0.419 & 0.876 & 0.872 & 0.858 & 0.67 & 79 \\
\hline PCB 170 & 0.715 & 6.74 & 1.08 & 2.82 & 2.97 & 2.87 & 2.4 & 83 \\
\hline PCB 172 & 0.138 & 1.22 & 0.325 & 0.572 & 0.601 & 0.572 & 0.41 & 72 \\
\hline PCB 174 & 0.0788 & 0.165 & 0.195 & 0.209 & 0.121 & 0.154 & 0.054 & 35 \\
\hline PCB 175 & 0.0657 & 0.521 & 0.123 & 0.225 & 0.224 & 0.232 & 0.18 & 76 \\
\hline PCB 176 & 0.0333 & 0.0317 & 0.0423 & 0.0386 & 0.0462 & 0.0384 & 0.0061 & 16 \\
\hline PCB 177 & 0.207 & 0.757 & 0.469 & 0.498 & 0.384 & 0.463 & 0.20 & 43 \\
\hline PCB 178 & 0.219 & 1.37 & 0.346 & 0.713 & 0.496 & 0.628 & 0.45 & 72 \\
\hline PCB $180+193$ & 2.15 & 24.3 & 4.53 & 8.41 & 9.33 & 9.75 & 8.7 & 89 \\
\hline PCB 183 & 0.719 & 7.66 & 1.54 & 3.19 & 3.04 & 3.23 & 2.7 & 83 \\
\hline PCB 185 & $<\mathrm{LOQ}$ & $<\mathrm{LOQ}$ & $<\mathrm{LOQ}$ & $<\mathrm{LOQ}$ & $<\mathrm{LOQ}$ & $<$ LOQ & & \\
\hline PCB 187 & 1.36 & 8.35 & 3.57 & 5.99 & 5.05 & 4.86 & 2.6 & 54 \\
\hline PCB 188 & 0.0196 & 0.0449 & 0.0256 & 0.0270 & 0.0312 & 0.0297 & 0.0095 & 32 \\
\hline PCB 189 & $<\mathrm{LOQ}$ & 0.0116 & $<\mathrm{LOQ}$ & $<\mathrm{LOQ}$ & $<\mathrm{LOQ}$ & $<\mathrm{LOQ}$ & & \\
\hline PCB 191 & 0.0263 & 0.264 & 0.0455 & 0.105 & 0.113 & 0.111 & 0.093 & 84 \\
\hline PCB 194 & 0.255 & 2.37 & 0.475 & 0.787 & 1.01 & 0.979 & 0.83 & 85 \\
\hline PCB 195 & 0.0665 & 0.572 & 0.140 & 0.257 & 0.274 & 0.262 & 0.19 & 74 \\
\hline PCB 196 & 0.468 & 3.62 & 0.829 & 1.45 & 1.50 & 1.57 & 1.2 & 78 \\
\hline PCB 197 & 0.0302 & 0.283 & 0.0723 & 0.120 & 0.102 & 0.121 & 0.096 & 79 \\
\hline РCB 199 & 0.918 & 11.2 & 2.18 & 2.95 & 3.38 & 4.12 & 4.0 & 98 \\
\hline PCB 200 & $<\mathrm{LOQ}$ & $<\mathrm{LOQ}$ & $<\mathrm{LOQ}$ & $<\mathrm{LOQ}$ & $<$ LOQ & $<\mathbf{L O Q}$ & & \\
\hline РCB 201 & 0.218 & 1.91 & 0.680 & 0.788 & 0.671 & 0.854 & 0.63 & 74 \\
\hline РCB 202 & 0.148 & 0.567 & 0.203 & 0.322 & 0.233 & 0.295 & 0.16 & 56 \\
\hline PCB 205 & 0.0273 & 0.103 & 0.0369 & 0.0298 & 0.0720 & 0.0539 & 0.033 & 61 \\
\hline PCB 206 & $<\mathrm{LOQ}$ & 0.768 & $<\mathrm{LOQ}$ & 0.333 & 0.339 & 0.480 & 0.25 & 52 \\
\hline PCB 207 & 0.0624 & 0.268 & 0.0799 & 0.139 & 0.141 & 0.138 & 0.081 & 58 \\
\hline РCB 208 & 0.0970 & 0.306 & 0.108 & 0.142 & 0.138 & 0.158 & 0.085 & 53 \\
\hline РСB 209 & 0.0601 & 0.361 & 0.0795 & 0.201 & 0.193 & 0.179 & 0.12 & 67 \\
\hline
\end{tabular}

